\title{
OECD MCCI Project \\ 2-D Core Concrete Interaction (CCI) Tests: \\ CCI-5 Data Report
}

\author{
Rev. 1 - Final \\ November 2010
}

by:

M. T. Farmer, D. J. Kilsdonk, S. Lomperski, and R. W. Aeschlimann

Nuclear Engineering Division

Argonne National Laboratory

9700 S. Cass Avenue

Argonne, IL 60439 USA 
OECD/MCCI-2009-TR06 Rev. 1

\section{Table of Contents}

1.0 INTRODUCTION

.1

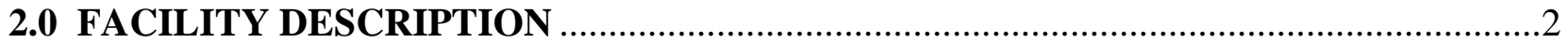

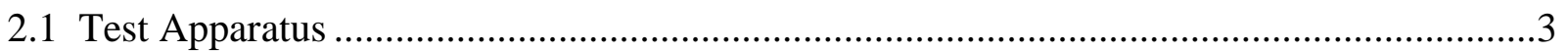

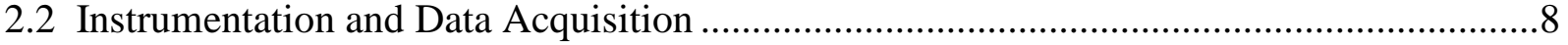

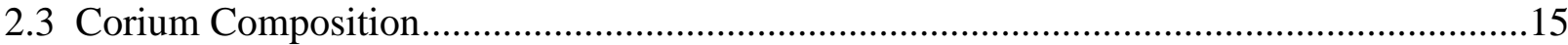

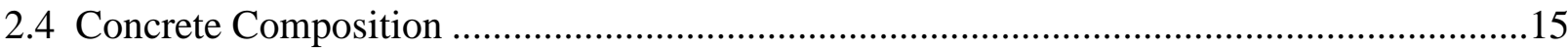

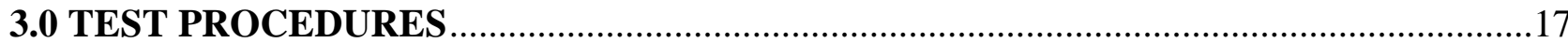

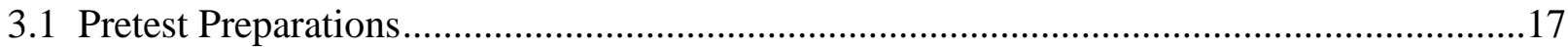

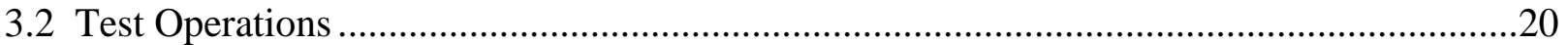

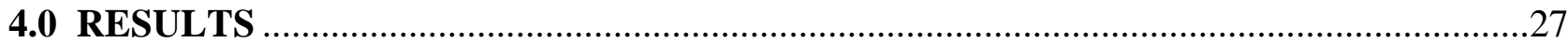

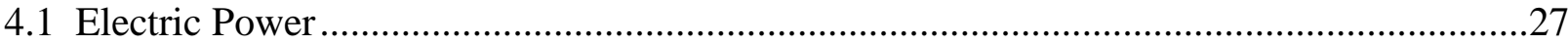

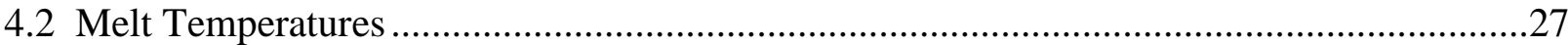

4.3 Concrete Basemat and Sidewall Ablation Rates..........................................................28

4.4 Posttest Debris Examination and Chemical Analysis Results .........................................30

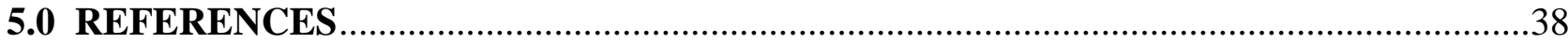

APPENDIX A: Data Acquisition System Channel Assignments.........................................39

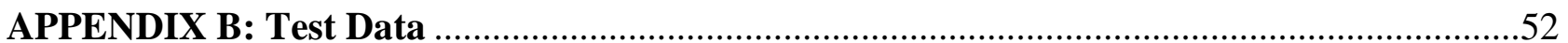

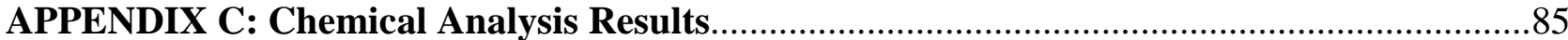




\section{List of Figures}

Figure

Page

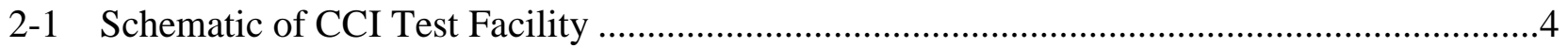

2-2 Top View of Lower Test Section ...........................................................................4

2-3 Side View of Lower Test Section Showing Inert MgO Sidewall Sections ...........................5

2-4 Side View of Lower Test Section Showing Concrete Sidewall .........................................5

2-5 Test Section Water Supply System ........................................................................

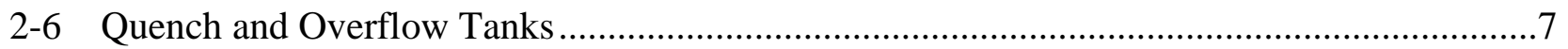

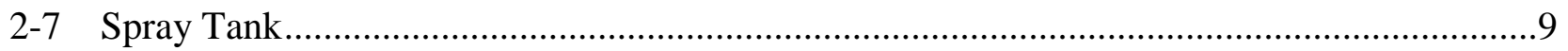

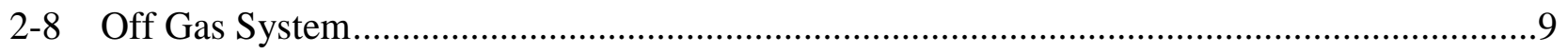

2-9 Illustration of CCI-5 Crust Lance Assembly Mounted in Test Section ................................10

2-10 Test Section Pressure Relief System …................................................................... 11

2-11 Photograph of Rupture Disk and Counter-Weighted Check Valve.....................................11

2-12 Plan View of Basemat Instrumentation Layout (dimensions are in cm) ............................12

2-13 Elevation View of Basemat Type C Thermocouple Locations .........................................13

2-14 Exterior View of Concrete Sidewall Form Showing Instrument Locations.........................13

2-15 CCI Data Acquisition and Control Systems .......................................................... 14

3-1 Illustration of Thermite Sample Train Installed in Test Section .......................................19

3-2 Voltage Reading Across Thermite Igniter Shunt ..........................................................22

3-3 Bulk Melt Temperature Data over the First 5 Minutes of the Interaction............................22

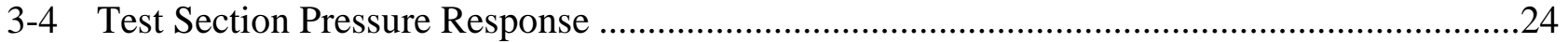

3-5 Quench System Tank Differential Pressure Responses (the range of these

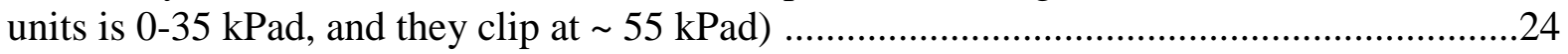

3-6 Photo of Aerosol Plugging of Offgas Flowmeter Inlet (pipe ID is $10 \mathrm{~cm}$ ) .......................25

3-7 Miscellaneous Temperatures in Quench and Off-Gas Systems ........................................25

3-8 Thermal Response in South $\mathrm{MgO}$ Sidewall at the $+10 \mathrm{~cm}$ Elevation ................................26

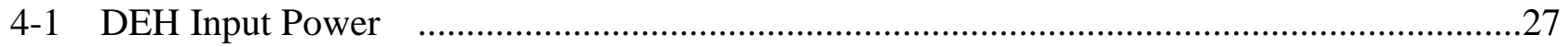

4-2 Melt Temperatures Measured During CCI-5 ...............................................................28

4-3 Basemat Axial Ablation Front Location .......................................................................29

4-4 North Sidewall Lateral Ablation Front Location $\quad$........................................................29

4-5 Top Views of the Test Section (a) After Lid Removal, and (b) After Removal of Top Section, Middle Section, and Test Section Transition Plate..... 32 


\section{List of Figures (Contd.)}

Figure

4-6 Side View of Lower Section (from west) After Removal of MgO Sidewalls........................33

4-7 View from the West of the Solidified Corium over the Basemat..........................................34

4-8 View from the North of the Solidified Corium over the Basemat .....................................35

4-9 (a) Perspective and (b) Close-up Photographs of Corium on the North

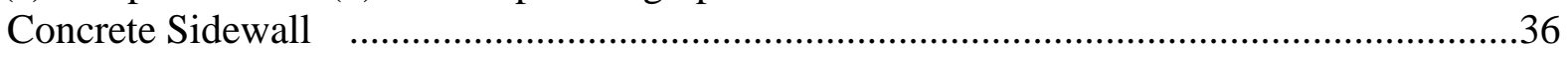

4-10 Posttest Debris Renderings as Viewed from the (a) West and (b) South ............................37

B-1 Compensator Temperature, Channels B0-B49 and B50-B99 ..........................................53

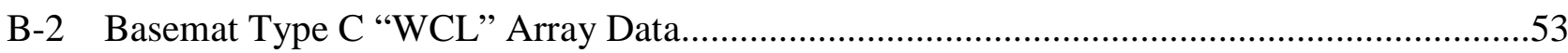

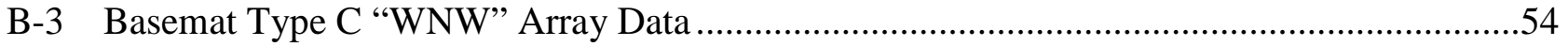

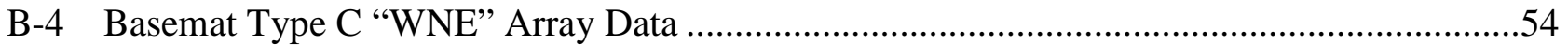

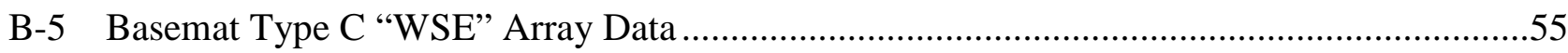

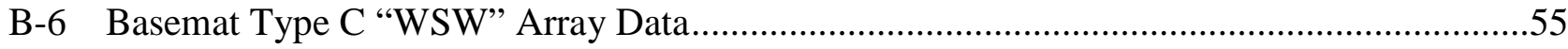

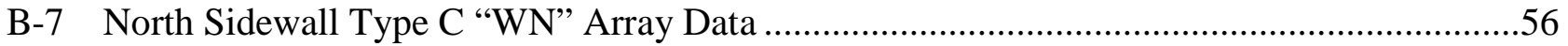

B-8 Melt Surface Temperature Optical Pyrometer OP-1 Data...............................................56

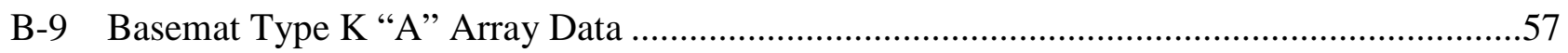

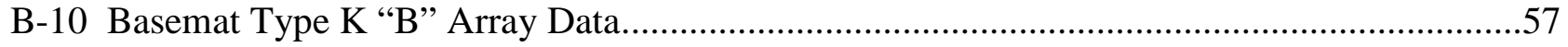

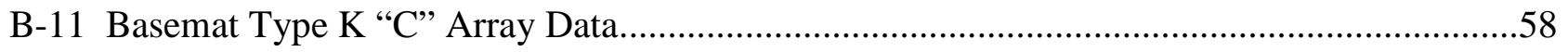

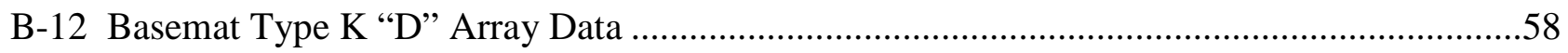

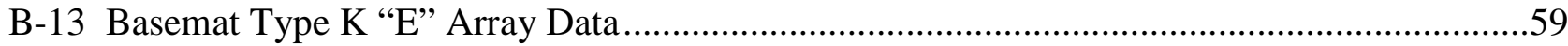

B-14 North Sidewall Type K “SWA” Array Data...................................................................59

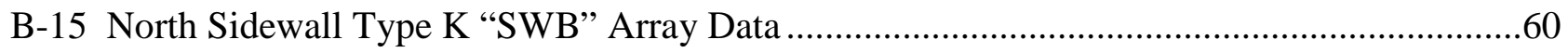

B-16 North Sidewall Type K "SWC” Array Data ...............................................................60

B-17 North Sidewall Type K “SWD” Array Data..............................................................61

B-18 North Sidewall Type K “SWE” Array Data ..............................................................61

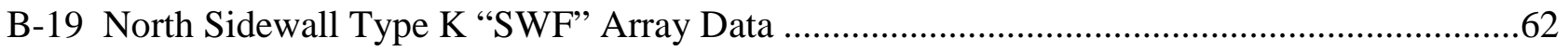

B-20 North Sidewall Type K “SWG” Array Data..................................................................62

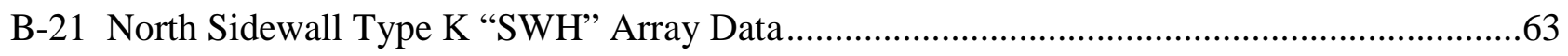

B-22 North Sidewall Type K “SWI” Array Data .................................................................63

B-23 North Sidewall Type K “SWJ” Array Data ....................................................................64 


\section{List of Figures (Contd.)}

Figure

B-24 North Sidewall Type K “SWK” Array Data...................................................................64

B-25 North Sidewall Type K “SWL” Array Data .................................................................65

B-26 North Sidewall Type K “SWM” Array Data .............................................................65

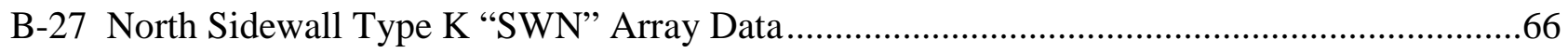

B-28 North Sidewall Type K “SWO” Array Data..................................................................66

B-29 Thermocouple Compensator Data for Channels Q0-Q49 and Q50-Q99............................67

B-30 Test Section Sidewall Heat Loss Data at -17.5 cm Elevation............................................67

B-31 Test Section Sidewall Heat Loss Data at -10.0 cm Elevation.............................................68

B-32 Test Section Sidewall Heat Loss Data at $-7.5 \mathrm{~cm}$ Elevation..............................................68

B-33 Test Section Sidewall Heat Loss Data at $+2.5 \mathrm{~cm}$ Elevation............................................69

B-34 Test Section Sidewall Heat Loss Data at $+10.0 \mathrm{~cm}$ Elevation..........................................69

B-35 Test Section Sidewall Heat Loss Data at $+12.5 \mathrm{~cm}$ Elevation..........................................70

B-36 Test Section Sidewall Heat Loss Data at the $+67.5 \mathrm{~cm}$ Elevation ......................................70

B-37 Test Section Sidewall Heat Loss Data at the $+92.2 \mathrm{~cm}$ Elevation......................................71

B-38 Test Section Sidewall Heat Loss Data at the $+148.8 \mathrm{~cm}$ Elevation...................................71

B-39 Test Section Sidewall Heat Loss Data at the $+174.7 \mathrm{~cm}$ Elevation...................................72

B-40 Test Section Sidewall Heat Loss Data at the $+193.0 \mathrm{~cm}$ Elevation...................................72

B-41 Test Section Sidewall Heat Loss Data at the $+211.3 \mathrm{~cm}$ Elevation....................................73

B-42 Test Section Sidewall Heat Loss Data at the $+229.6 \mathrm{~cm}$ Elevation...................................73

B-43 Test Section Mainline Thermocouple Data .................................................................74

B-44 Test Section Plenum and Insertable Water Probe Thermocouple Data ..............................74

B-45 Quench Tank Water Volume, Coil Inlet, and Coil Outlet Temperatures .............................75

B-46 Temperatures in Water Supply, Quench, and Off Gas Systems .......................................75

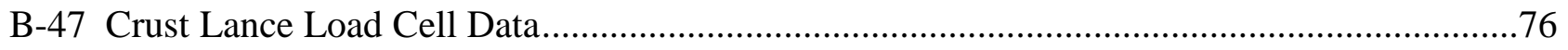

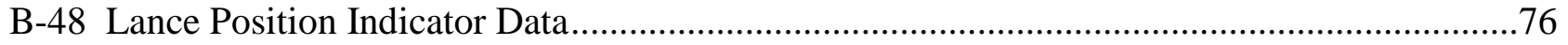

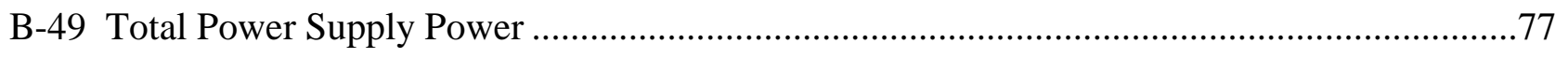

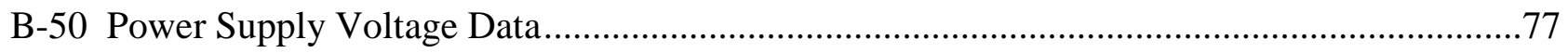

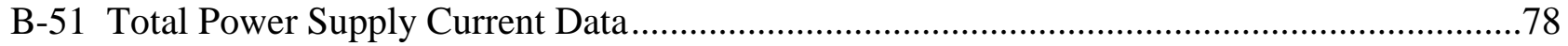

B-52 Power Supply Current Transformer Data ..................................................................78 


\section{List of Figures (Contd.)}

Figure

Page

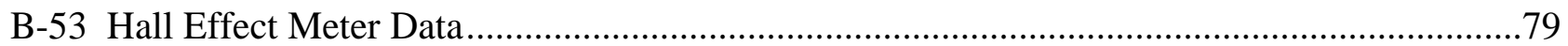

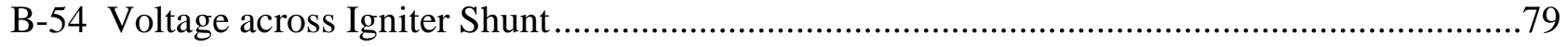

B-55 Pressure Transducer Power Supply Voltages ...........................................................8

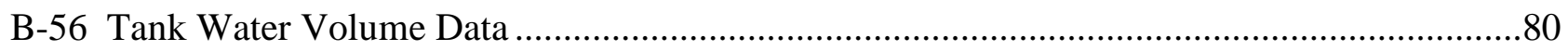

B-57 Supply and Quench System Tank Head Data (Backup) ..................................................81

B-58 Test Section Water Head Transducer Data.....................................................................81

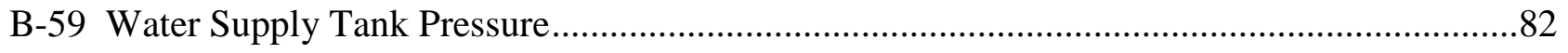

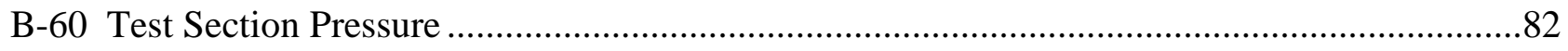

B-61 Quench/Overflow and Spray Tank Plenum Differential Pressures ...................................83

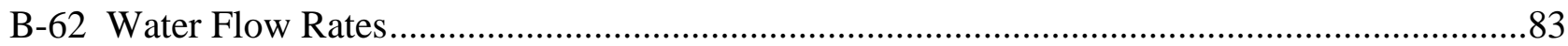

B-63 Test Section Helium Cover Gas Flow Rates................................................................84

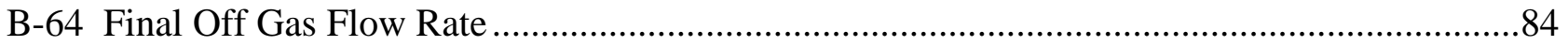

\section{List of Tables}

\section{Table}

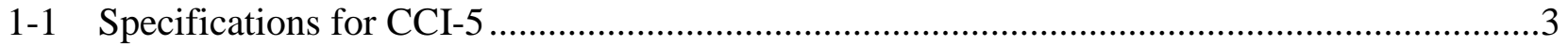

2-1 Post-Reaction Bulk Composition for CCI-5 Thermite ...................................................... 16

2-2 Detailed Pre- and Post-Reaction Compositions for CCI-5 Thermite ...................................16

2-3 Engineering Composition of CCI-5 Siliceous Concrete Basemat and Sidewall ....................16

2-4 Chemical Composition of Siliceous Concrete ..............................................................17

3-1 CCI-5 Event Sequence (times relative to onset of cavity ablation)...................................21

4-1 Chemical Analysis Results for Samples Collected from CCI-5 Posttest Debris....................31

A-1 "Concrete" DAS Channel Assignments for CCI-5 ..........................................................40

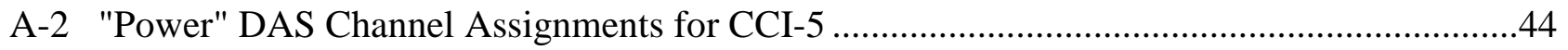

A-3 "Quench" DAS Channel Assignments for CCI-5 .......................................................48

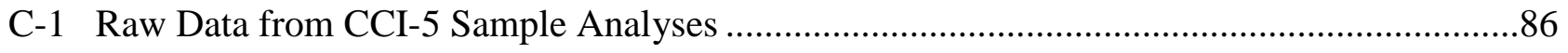




\subsection{INTRODUCTION}

Ex-vessel debris coolability is an important light water reactor (LWR) safety issue. For existing plants, resolution of this issue will confirm the technical basis for severe accident management guidelines (SAMGs). For new reactors, understanding this issue will help confirm the effectiveness of the design and implementation of new accident mitigation features and severe accident management design alternatives (SAMDAs). The first OECD-MCCI program conducted reactor material experiments focused on achieving the following technical objectives: i) provide confirmatory evidence for various cooling mechanisms through separate effect tests and data for severe accident code model development, and ii) provide longer-term twodimensional core-concrete interaction data for code assessment and improvement.

Debris cooling mechanisms investigated as part of the first MCCI program included: i) water ingression through cracks/fissures in the core debris, ii) melt eruption caused by gas sparging (volcanic-type event), and iii) large-scale crust mechanical failure leading to renewed bulk cooling. The results of this testing and associated analysis provided an envelope (principally determined by melt depth) for debris coolability. However, this envelope does not encompass the full range of melt depths that are calculated for all plant accident sequences. Cooling augmentation by additional means may be needed at the late stage to assure coolability for new reactor designs as well as for various accident sequences for existing reactors. In addition, the results of the CCI tests showed that lateral/axial power split is a function of concrete type. However, the first program produced limited data sets for code assessment. In light of significant differences in ablation behavior for different concrete types, additional data would be useful in reducing uncertainties and gaining confidence in code predictions.

Based on these findings, a workscope was defined for the follow-on MCCI program that can be divided into the following four categories:

1. Combined effect tests to investigate the interplay of different cooling mechanisms, and to provide data for model development and code assessment purposes.

2. Tests to investigate new design features to enhance coolability, applicable particularly to new reactor designs.

3. Tests to generate two-dimensional core-concrete interaction data.

4. Integral tests to validate severe accident codes.

Aside from these various testing categories, an analysis workscope was also defined to develop and validate debris coolability models to form the technical basis for extrapolating the experiment findings to plant conditions.

As one of the steps in satisfying these program objectives, the Management Board (MB) approved the conduct of a fifth longer-term 2-D Core-Concrete Interaction (CCI) experiment designed to provide information in several areas, including: i) lateral vs. axial power split during dry core-concrete interaction, ii) integral debris coolability data following late phase flooding, and iii) data regarding the nature and extent of the cooling transient following breach of the crust formed at the melt-water interface. The first three tests [1] in this experiment series investigated the interaction of fully oxidized PWR core melt compositions with specially designed concrete 
test sections that were initially $50 \mathrm{~cm} \times 50 \mathrm{~cm}$ in cross-sectional area. Both siliceous and limestone/common sand concrete types were addressed. The fourth test [2] examined the interaction of a partially oxidized BWR melt composition with limestone/common sand concrete.

The overall design objective of CCI-5 was to increase the test section aspect ratio (i.e., test section width/melt depth) to the greatest extent possible to more accurately mock up prototypic conditions. To this end, the project prepared two design documents $[3,4]$ that were submitted to the PRG for review. On this basis, the design was finalized, the apparatus was fabricated and assembled, and the experiment was conducted on September 25, 2008. Specifications for CCI-5 are provided in Table 1-1. The initial corium composition and concrete types were the same as those of CCI-3, but the dimensions and design of the test section were different. In particular, CCI-3 was conducted with a test section that featured two-ablating sidewalls with an initial basemat cross-section of $50 \mathrm{~cm} \times 50 \mathrm{~cm}$, whereas the CCI-5 test section featured one ablating concrete sidewall, an opposing $\mathrm{MgO}$ refractory sidewall, and a concrete basemat that was initially $50 \mathrm{~cm} \times 79 \mathrm{~cm}$ in cross-sectional area. The input power for CCI-5 during the dry ablation phase was specified to be $145 \mathrm{~kW}$, which was based on the requirement of providing an initial 'prototypic' heat flux of $\sim 160 \mathrm{~kW} / \mathrm{m}^{2}$ across all melt surfaces that were not in contact with insulating sidewall material. This is the same surface heat flux requirement used to specify the total input power for tests CCI-2 through CCI-4. The initial melt depth for CCI-5 was set at $25 \mathrm{~cm}$, which is the same as that used in previous tests. Since the surface area of the CCI-5 basemat was larger than that of previous tests, the initial melt mass to achieve this depth was increased considerably to $590 \mathrm{~kg}$. With these specifications, CCI-5 could be considered a repeat of CCI-3, but with the aspect ratio increased to the greatest extent possible using: i) available hardware and ii) an inert wall that provided a symmetry boundary condition on one side of the test section.

The objective of this data report is to provide the thermalhydraulic results from this test. To this end, a summary description of the test apparatus is provided first, followed by descriptions of the test operating procedure and key experiment results.

\subsection{FACILITY DESCRIPTION}

The overall facility design and operating procedures for CCI-5 were similar to those used in the previous four tests [1-2]. However, at the $3^{\text {rd }}$ PRG meeting for MCCI-2, the MB directed the project to increase the test section aspect ratio to the greatest extent possible. Given the test section overall planar dimensions, the approach for reaching this objective was to increase the aspect ratio to the highest possible value to more accurately mock up conditions at plant scale by incorporating one inert $\mathrm{MgO}$ sidewall into the overall design. This step created a symmetry (i.e., $\sim$ adiabatic) boundary condition on one side of the test section which, in theory, doubled the aspect ratio for a given basemat width. With the symmetry boundary condition, the test simulated erosion in a $50 \mathrm{~cm} \times 158 \mathrm{~cm}$ test section. Additional details regarding this modification are provided in the balance of this section, along with a general description of the overall facility for CCI-5. Specifications for the experiment were provided previously in Table $1-1$. 
OECD/MCCI-2009-TR06 Rev. 1

Table 1-1. Specifications for CCI-5.

\begin{tabular}{|l|l|}
\hline \multicolumn{1}{|c|}{ Parameter } & \multicolumn{1}{c|}{ Specification } \\
\hline Corium & $100 \%$ oxidized PWR with 15 wt \% siliceous concrete \\
\hline Concrete type & Siliceous concrete (CEA-type) \\
\hline Initial basemat dimension & $50 \mathrm{~cm}$ x $79 \mathrm{~cm}$ \\
\hline Initial melt mass $\left(\right.$ depth $\left.^{\mathrm{a}}\right)$ & $590 \mathrm{~kg}(25 \mathrm{~cm})$ \\
\hline Test section sidewall construction & $\begin{array}{l}\text { Nonelectrode wall No. 1: concrete } \\
\text { Nonelectrode wall No. 2: MgO protected by } \mathrm{UO}_{2} \text { pellet layer. } \\
\text { Electrode walls: MgO protected by } \mathrm{UO}_{2} \text { pellet layers. }\end{array}$ \\
\hline Lateral and axial ablation limits & 40 and $42.5 \mathrm{~cm}$, respectively \\
\hline System operating pressure & Atmospheric \\
\hline $\begin{array}{l}\text { Melt formation technique } \\
\text { (timescale) }\end{array}$ & Chemical reaction $(\sim 30$ seconds) \\
\hline Initial melt temperature & $1950{ }^{\circ} \mathrm{C}$ \\
\hline Melt heating technique & Direct Electrical (Joule) Heating \\
\hline Power input prior to water addition & Constant power at $145 \mathrm{~kW}$ \\
\hline Criteria for water addition & $\begin{array}{l}1) 6.0 \text { hours of operation with DEH input, 2) lateral ablation } \\
\text { reaches 35 cm, or 3) axial ablation reaches 37.5 cm }\end{array}$ \\
\hline Inlet water temperature & $20{ }^{\circ} \mathrm{C}$ \\
\hline Inlet water flow rate & 2 liters/second \\
\hline Sustained water depth over melt & $50 \pm 5$ cm \\
\hline Power input after water addition & Constant voltage \\
\hline Test termination criteria & $\begin{array}{l}1) \mathrm{T}_{\text {melt }}<\text { concrete solidus, 2) concrete ablation is arrested, 3) } \\
\text { maximum lateral/axial ablation limit is reached, or 4) 1.5 hours } \\
\text { operation with water present in the cavity. }\end{array}$ \\
\hline
\end{tabular}

\subsection{Test Apparatus}

The CCI facility consisted of a test apparatus, a power supply for Direct Electrical Heating (DEH) of the corium, a water supply system, two steam condensation (quench) tanks, a ventilation system to complete filtration and exhaust the off-gases, and a data acquisition system. A schematic illustration of the facility for CCI-5 is provided in Figure 2-1. The apparatus consisted of three rectilinear sidewall sections and a lid. The overall structure was $3.4 \mathrm{~m}$ tall. The two upper sidewall sections had a square internal cross sectional area of $50 \mathrm{~cm}$ x $50 \mathrm{~cm}$.

The test section for containment of the core melt was located at the bottom of the apparatus. A top view of this component is shown in Figure 2-2, while cross-sectional views of the electrode and non-electrode sidewalls are provided in Figures 2-3 and 2-4, respectively. The thickness of the new non-electrode sidewall was the same as the existing $\mathrm{MgO}$ electrode walls (i.e., $25 \mathrm{~cm}$ ), and it was also protected with a crushed $\mathrm{UO}_{2}$ pellet liner. This approach had been found to provide an inert (i.e., non-ablative) and highly insulated wall surface. As shown in Figure 2-4, the underside of the test section transition plate was exposed due to the addition of the thin $\mathrm{MgO}$ sidewall. To provide thermal protection, the plate was lined with $\mathrm{Al}_{2} \mathrm{O}_{3}$ insulation and a tungsten heat shield. A similar heat shield design was also used to protect the inner surface of the ACE/MCCI test apparatus lid. [5] The thickness of the concrete sidewall was the same as that used in the CCI-3 test. [1] 
OECD/MCCI-2009-TR06 Rev. 1

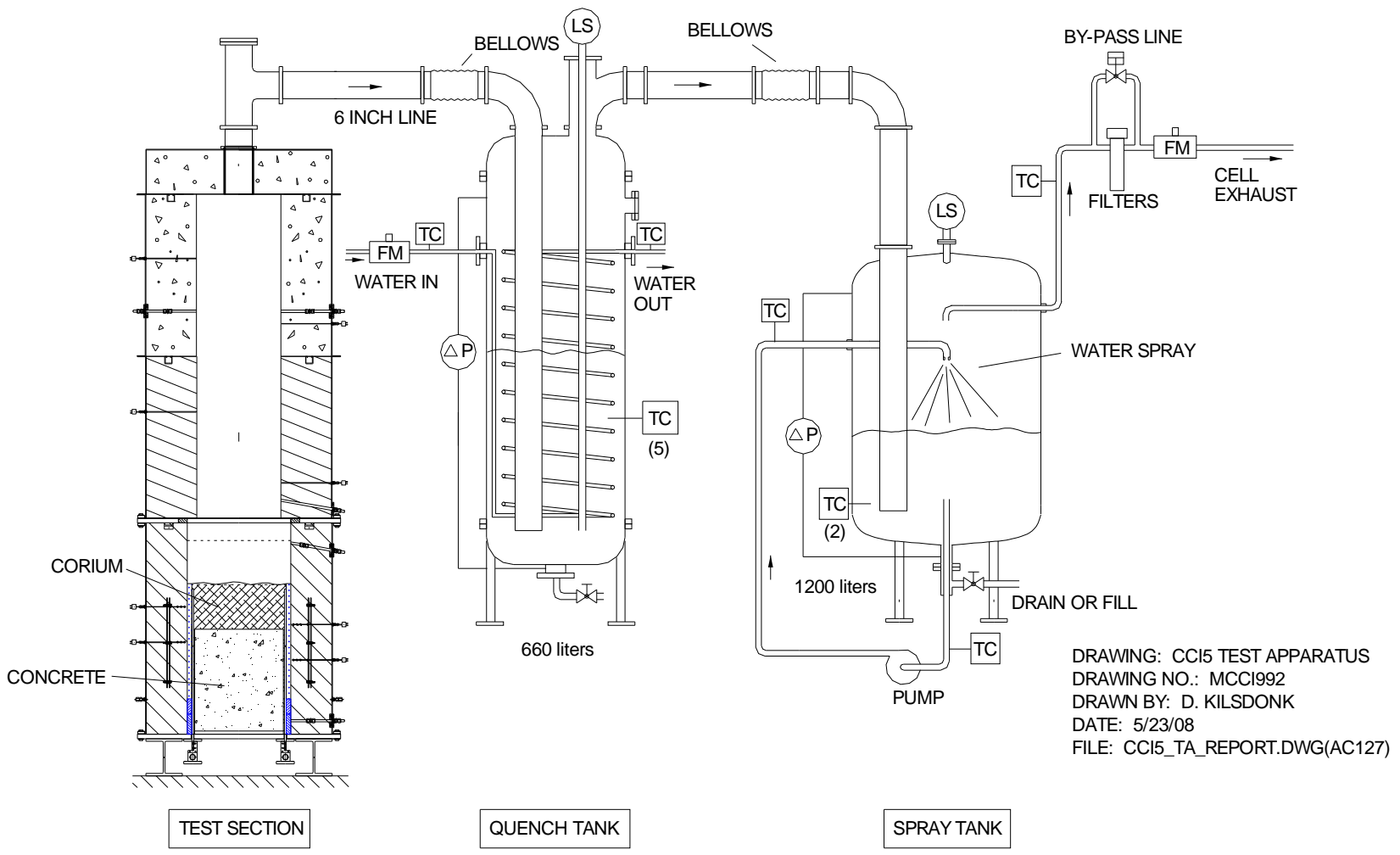

Figure 2-1. Schematic of CCI Test Facility.

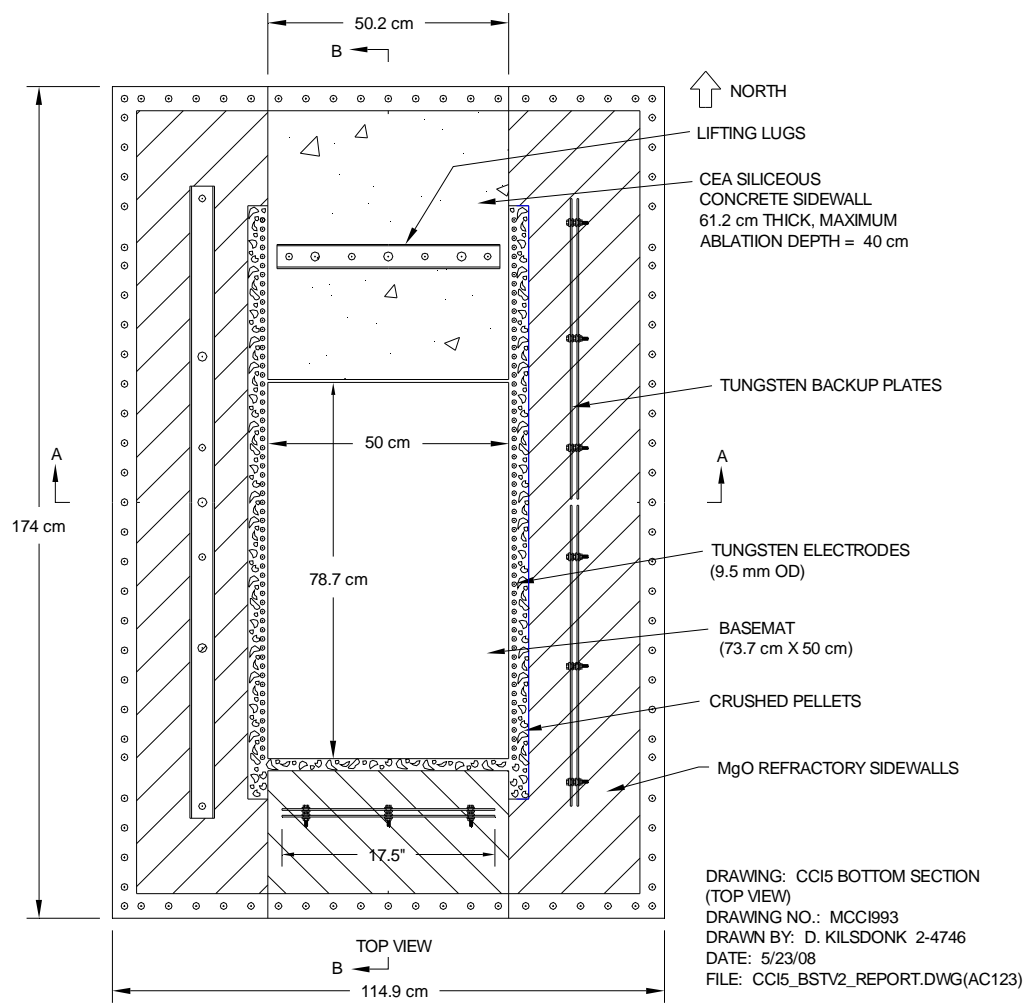

Figure 2-2. Top View of Lower Test Section. 


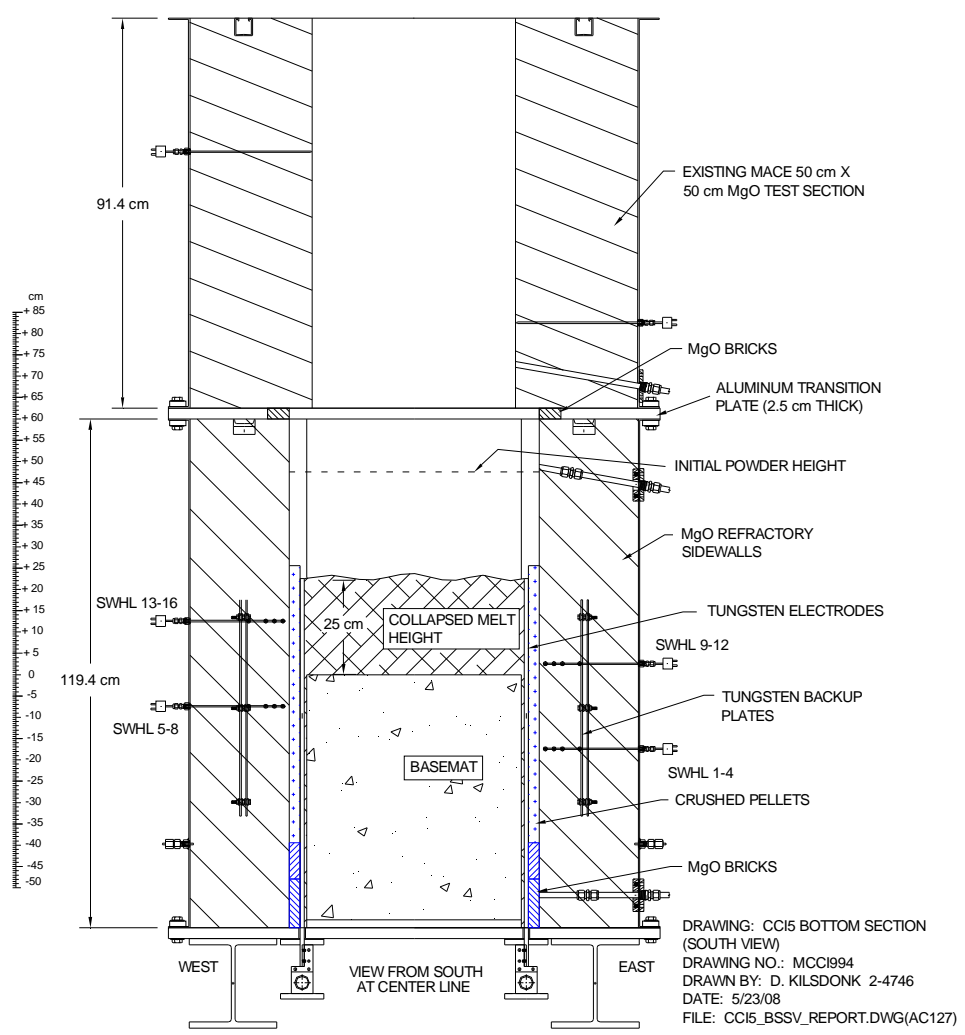

Figure 2-3. Side View of Lower Test Section Showing Inert MgO Sidewall Sections.

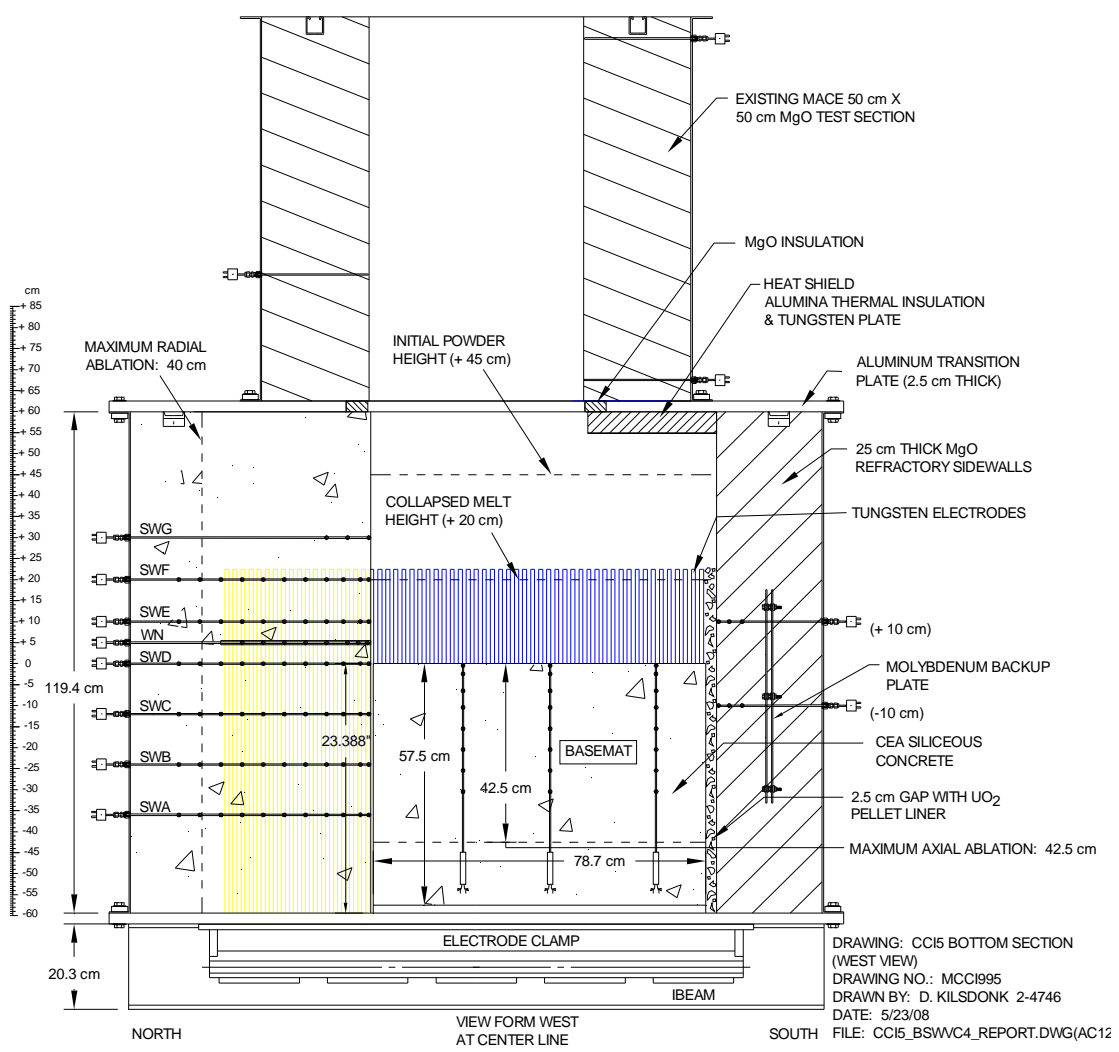

Figure 2-4. Side View of Lower Test Section Showing Concrete Sidewall. 
The selected sidewall dimensions increased the basemat width from $50 \mathrm{~cm}$ in CCI-3 to 79 $\mathrm{cm}$ for the current design. Taking credit for the symmetry boundary condition, then the aspect (width/melt depth) ratio was increased from $(25 \mathrm{~cm} / 25 \mathrm{~cm}=) 1.0$ in test CCI-3 to $(79 \mathrm{~cm} / 25 \mathrm{~cm}$ $=) 3.2$ for CCI-5, given the initial melt depth of $25 \mathrm{~cm}$ for CCI-5 (see Table 1-1). Note that the safety plan for the CCI tests assumed that a minimum thickness of $15 \mathrm{~cm}$ was maintained for all concrete components to ensure final containment of the melt. On this basis, up to $40 \mathrm{~cm}$ of lateral ablation could be accommodated in the concrete sidewall. Conversely, up to $42.5 \mathrm{~cm}$ of axial ablation could be accommodated given the initial basemat thickness of $57.5 \mathrm{~cm}$.

As shown in Figures 2-2 and 2-3, the concrete and $\mathrm{MgO}$ sidewalls were contained within a flanged steel forms that were used to secure the lower section to the balance of the existing test section components with the aluminum transition plate. The flanges allowed the lower sidewalls to be disassembled to reveal the solidified corium following the test. As previously noted, a layer of crushed $\mathrm{UO}_{2}$ pellets was used to protect the interior surface of the $\mathrm{MgO}$ sidewalls against thermo-chemical attack by the corium. Molybdenum and tungsten plates were embedded in the sidewalls to stop erosion in case the $\mathrm{UO}_{2}$ pellet layer failed to provide adequate protection. Multi-junction Type $\mathrm{C}$ thermocouple assemblies were cast within the sidewalls so that the timedependent heat loss from the melt could be calculated from the local temperature gradient and the thermal conductivity of the MgOThe melt was produced through an exothermic chemical reaction yielding the target melt mass over a timescale of $\sim 30$ seconds. After the chemical reaction, DEH simulating decay heat was applied through two banks of tungsten electrodes. As shown in Figures 2-2 and 2-3, the electrodes lined the interior surfaces of the two opposing $\mathrm{MgO}$ sidewalls. The electrodes were $9.5 \mathrm{~cm}$ in diameter and aligned in a row with a pitch of $1.9 \mathrm{~cm}$. They were attached by copper clamps and water-cooled buss bars to a $560 \mathrm{~kW}$ AC power supply. As shown in Figure 2-2, the electrodes spanned a total width of $120 \mathrm{~cm}$ on each sidewall of the lower section. At the start of the experiment, the electrical current was drawn through the center, $79 \mathrm{~cm}$-wide section of electrodes that were in direct contact with the melt. As the test progressed and the concrete sidewall was eroded, additional electrodes were exposed to the corium. Current was drawn through these newly exposed heating elements, thereby maintaining a uniform internal heat pattern in the melt over the course of the experiment. With the overall electrode span of $120 \mathrm{~cm}$, the entire $40 \mathrm{~cm}$ of lateral sidewall erosion could be accommodated while ensuring that the entire melt cross-sectional area was in contact with the electrodes.

After the melt was formed, ablation of the concrete basemat and sidewall would eventually commence. As shown in Figure 2-1, a large (15 cm diameter) gas line was used to vent the helium cover gas and the various gas species arising from the core-concrete interaction (i.e., $\mathrm{CO}, \mathrm{CO}_{2}, \mathrm{H}_{2} \mathrm{O}$, and $\mathrm{H}_{2}$ ) into adjacent tanks that were partially filled with water. In the initial phase of the experiment when the cavity remained dry, the tanks served to cool the offgases and filter aerosols generated from the core-concrete interaction.

After a specified period of core-concrete interaction, the cavity was to be flooded using an instrumented water supply system (Figure 2-5). The water entered the test section through two weirs located in the opposing (non-electrode) sidewalls of the top test section. Steam and concrete decomposition gases passed from the test section through the $15 \mathrm{~cm}$ vent line into an instrumented quench tank (Figure 2-6) that was equipped with a cooling coil to remove heat from steam condensation, thereby maintaining a subcooled state. If the condensate level in the 
tank rose to a level of $560 \mathrm{l}$, spillover into an adjacent overflow tank would occur. The quench tank and the interconnecting piping were insulated to minimize heat losses.

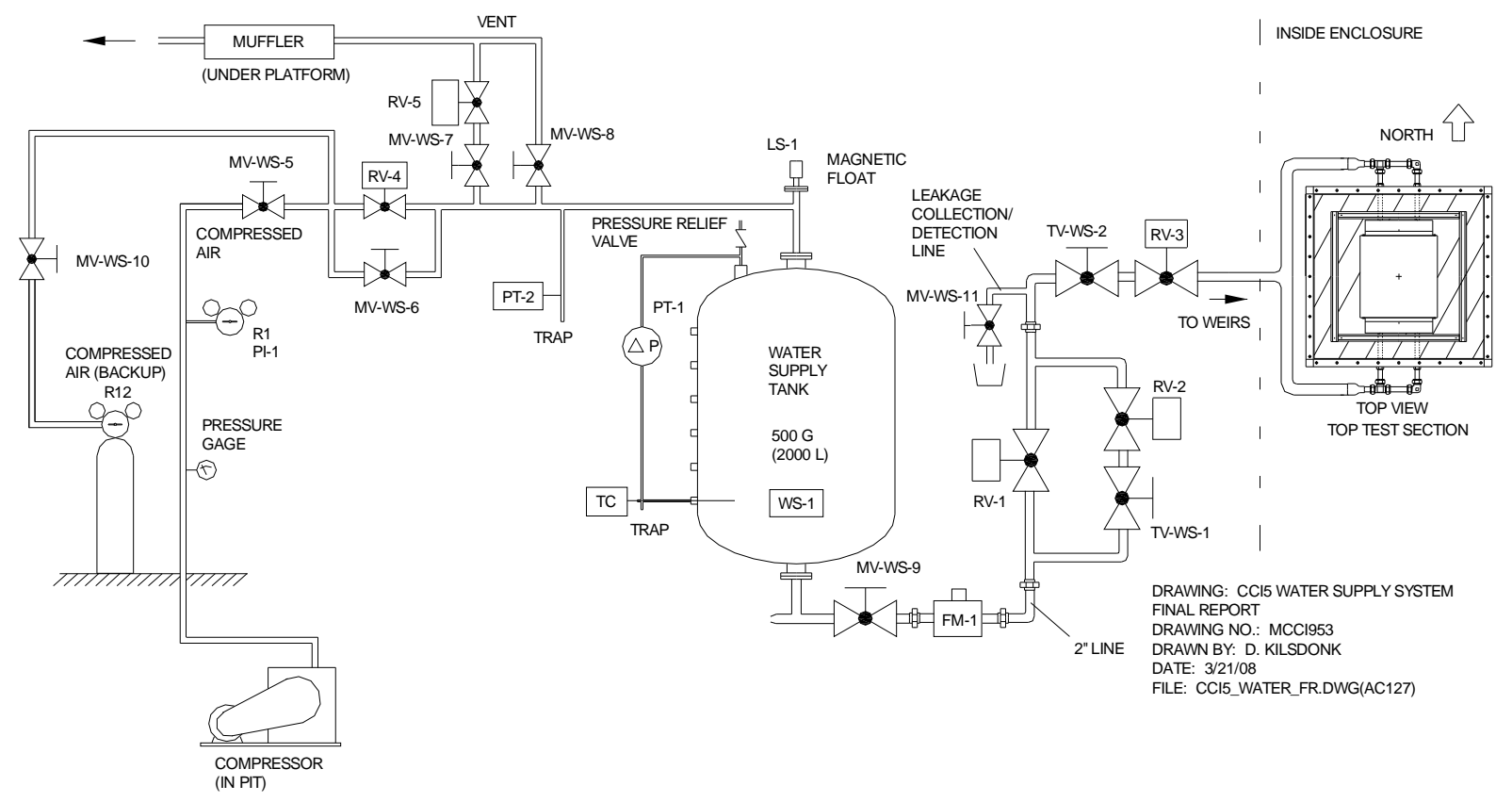

Figure 2-5. Test Section Water Supply System.

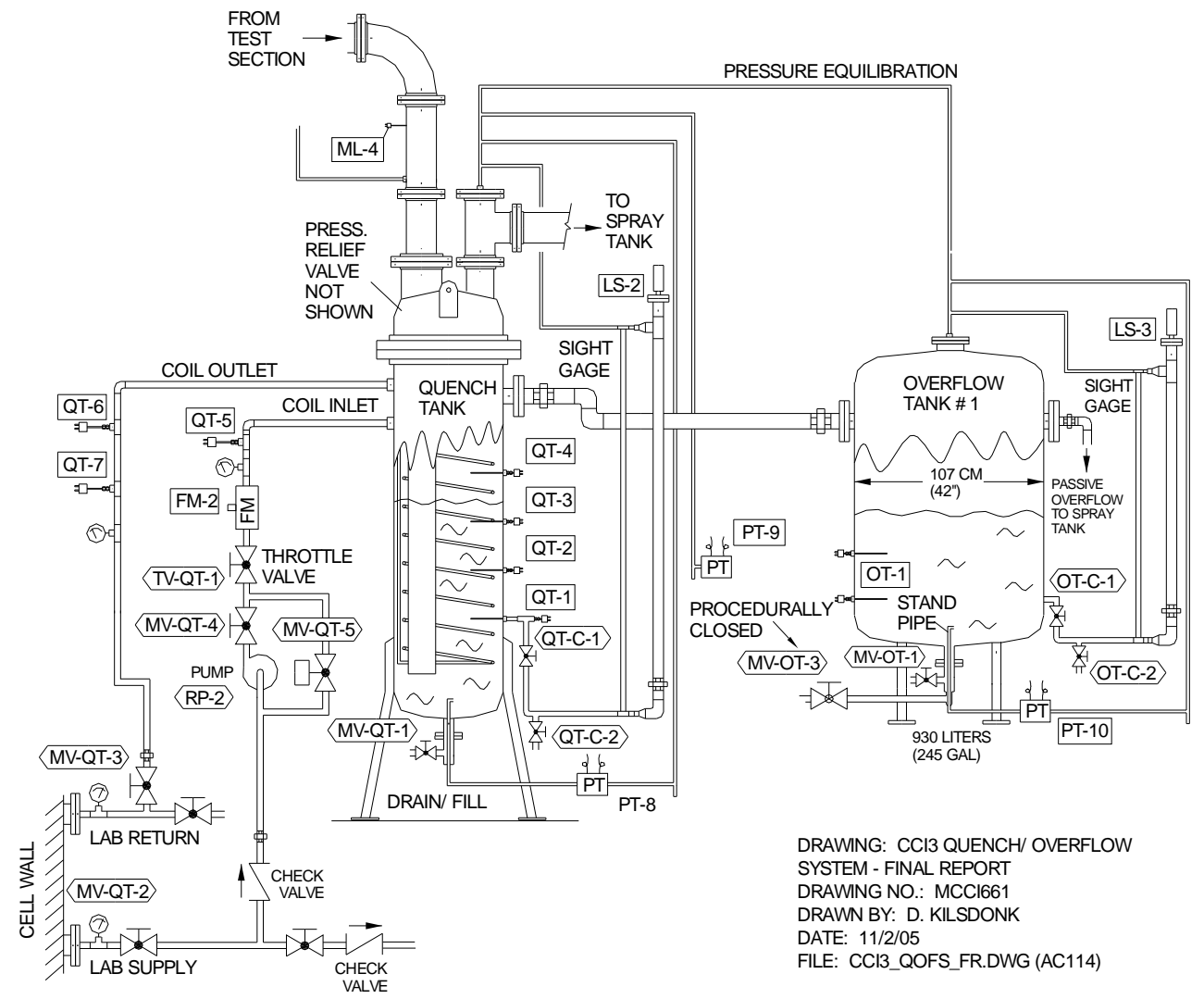

Figure 2-6. Quench and Overflow Tanks. 
A secondary spray tank was connected to the quench tank by a $15 \mathrm{~cm}$ diameter vent line (Figure 2-7). In situations when the steam generation rate overwhelmed the primary quench tank, the secondary spray tank served to condense the remaining steam. The spray tank and interconnecting piping were also insulated to minimize heat losses.

An off gas system (Figure 2-8) filtered noncondensable concrete decomposition gases as well as test section covergas exiting the spray tank before venting the gas stream to the cell atmosphere. The gas stream first passed through a flow separator and filter bank to remove any remaining particulate. The flow then passed through the final off gas flowmeter to the cell atmosphere. The filters were equipped with a passive counter-weighted check valve set to open at a nominal differential pressure of $7 \mathrm{kPa}$. The bypass valve was provided to ensure that a vent path for the test section was always available in the event that the filters become plugged during the experiment.

After a specified time with water present in the cavity, the crust formed at the melt-water interface was to be broken with an insertable crust lance (Figure 2-9) to obtain data on the crust breach cooling mechanism. The lance was made from $2.54 \mathrm{~cm}$ diameter, 304 stainless steel rod with a pointed tip. The lance contained an electrical isolation hub so that there was no need to terminate power input to the melt during the crust loading procedure. As shown in Figure 2-9, the driving force for the lance was simply a $450 \mathrm{~kg}$ dead weight that was remotely lowered with the crane during the test.

Finally, the test section was also equipped with an instrumented pressure relief system to prevent over-pressurization and possible failure of the test section (Figures 2-10 and 2-11). The system consisted of a $15 \mathrm{~cm}$ diameter vent line from the test section to an auxiliary tank that was initially filled with 4001 of water. This tank was open to the atmosphere. The pressure relief line included a passive, counter-weighted check valve set to open at a pressure of nominally 68 $\mathrm{kPad}$. A rupture diaphragm $(68 \pm 13.4 \mathrm{kPad})$ upstream from the check valve prevented any flow through the line unless the pressure in the test section exceeded the design value of $68 \mathrm{kPad}$. The line was also equipped with a vacuum breaker valve to prevent water hammer from occurring from steam condensation should the relief valve open and then reseat after introduction into the test section. The initial tank water inventory was provided to cool gases from the test section and to remove aerosols before the noncondensable gases were passed into the cell atmosphere. Instruments were provided to measure water depth and temperature so that the steam condensation rate could be determined if the relief system activated after water addition into the test section.

\subsection{Instrumentation and Data Acquisition}

The CCI facility was instrumented to monitor and guide experiment operation and to $\log$ data for subsequent evaluation. Principal parameters that were monitored during the course of the test included the power supply voltage, current, and gross input power to the melt; melt temperature and temperatures within the concrete basemat and sidewall; crust lance position and applied load; supply water flow rate; water volume and temperature within the test apparatus, and water volume and temperature within the quench system tanks. Other key data recorded by 
the DAS included temperatures within test section structural sidewalls, off gas temperature and flow rate, and pressures at various locations within the system.

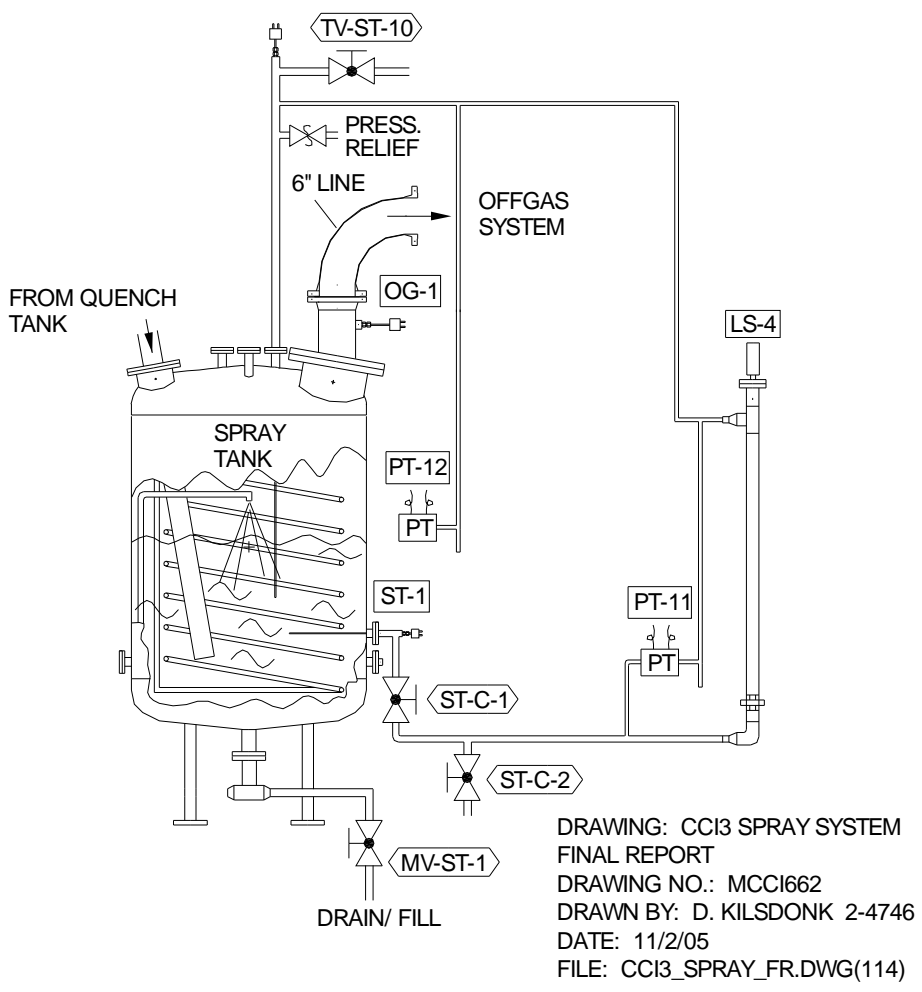

Figure 2-7. Spray Tank.

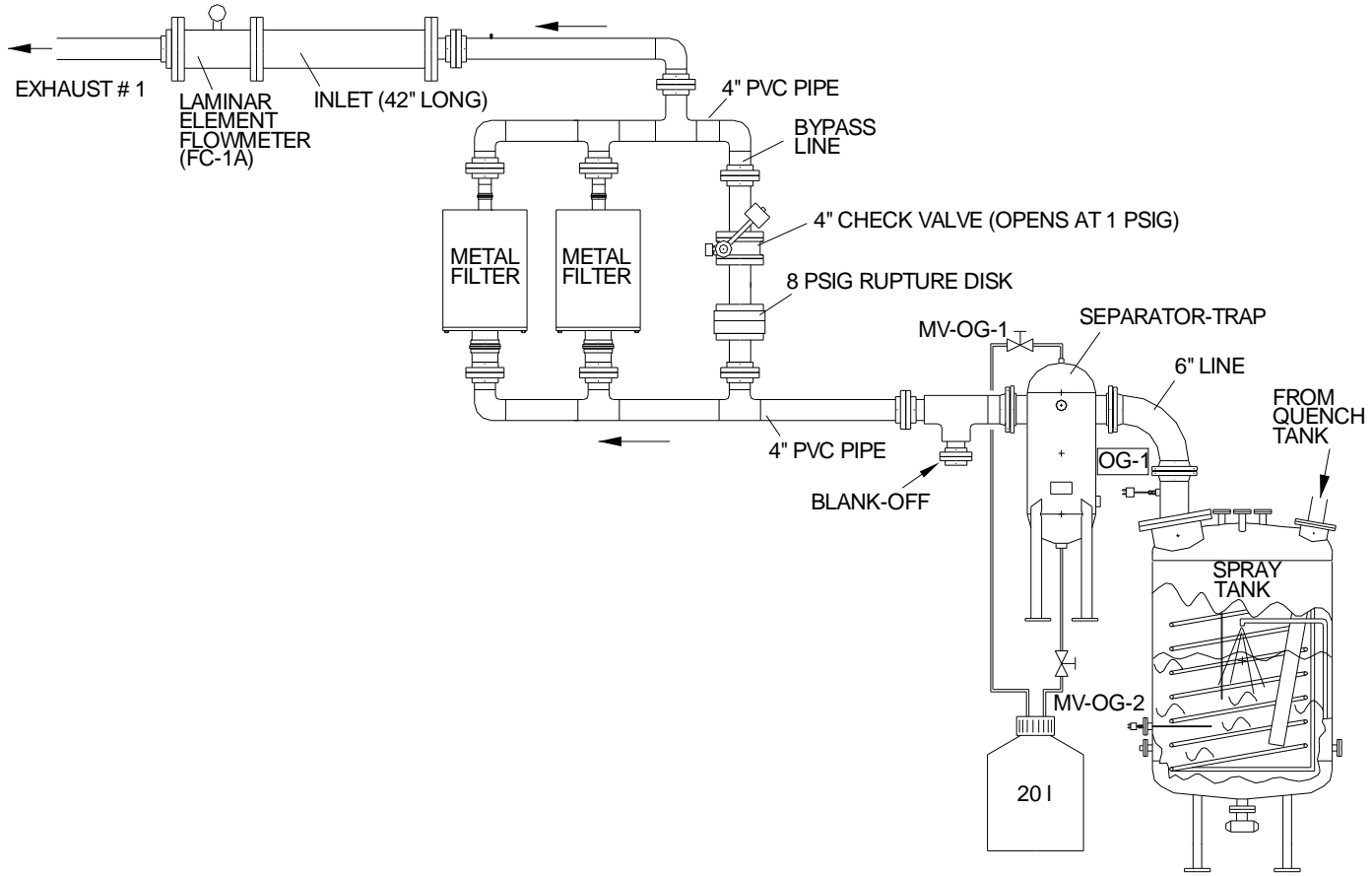

Figure 2-8. Off Gas System. 
OECD/MCCI-2009-TR06 Rev. 1

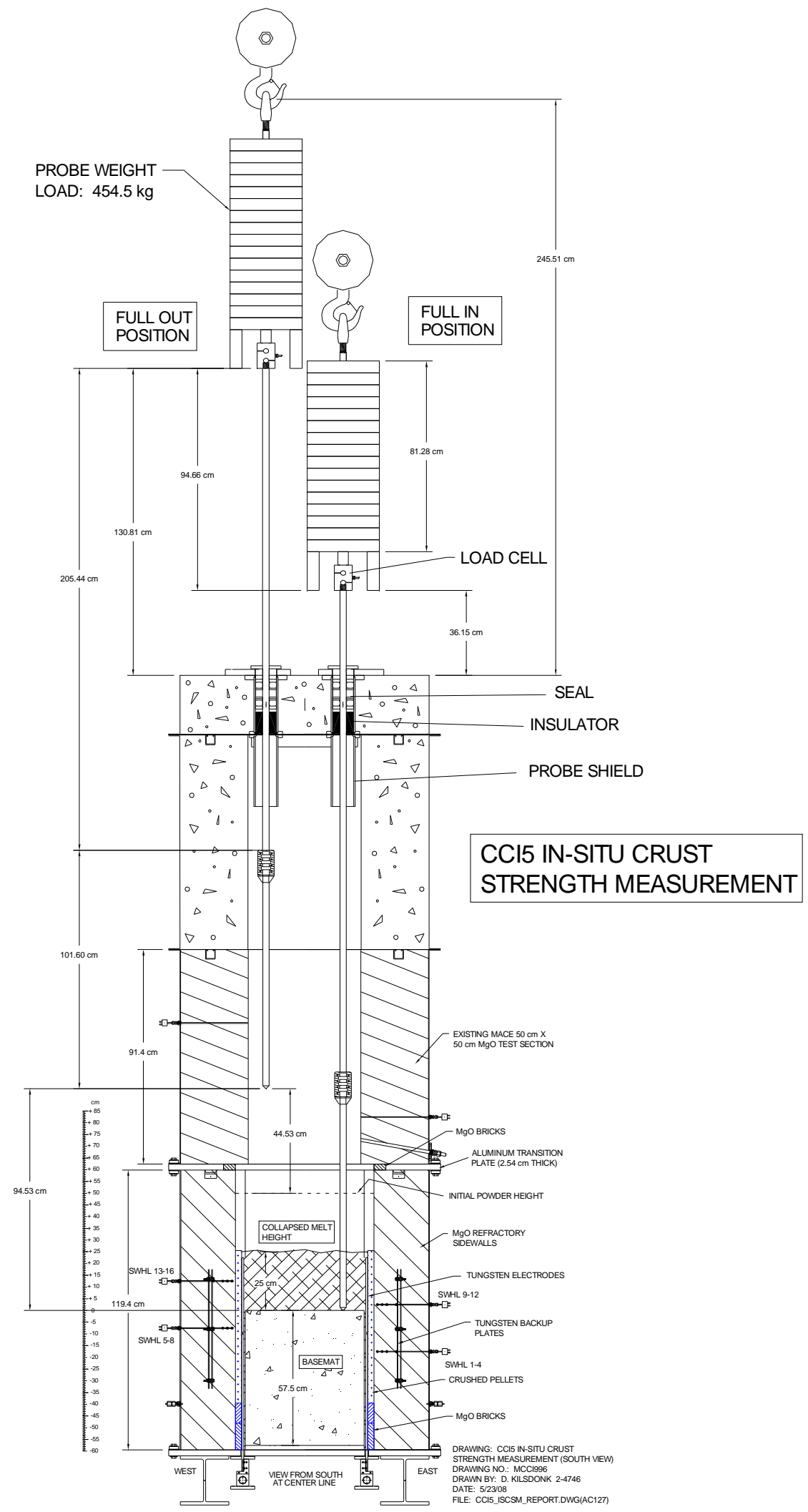

Figure 2-9. Illustration of CCI-5 Crust Lance Assembly Mounted in Test Section. 
OECD/MCCI-2009-TR06 Rev. 1

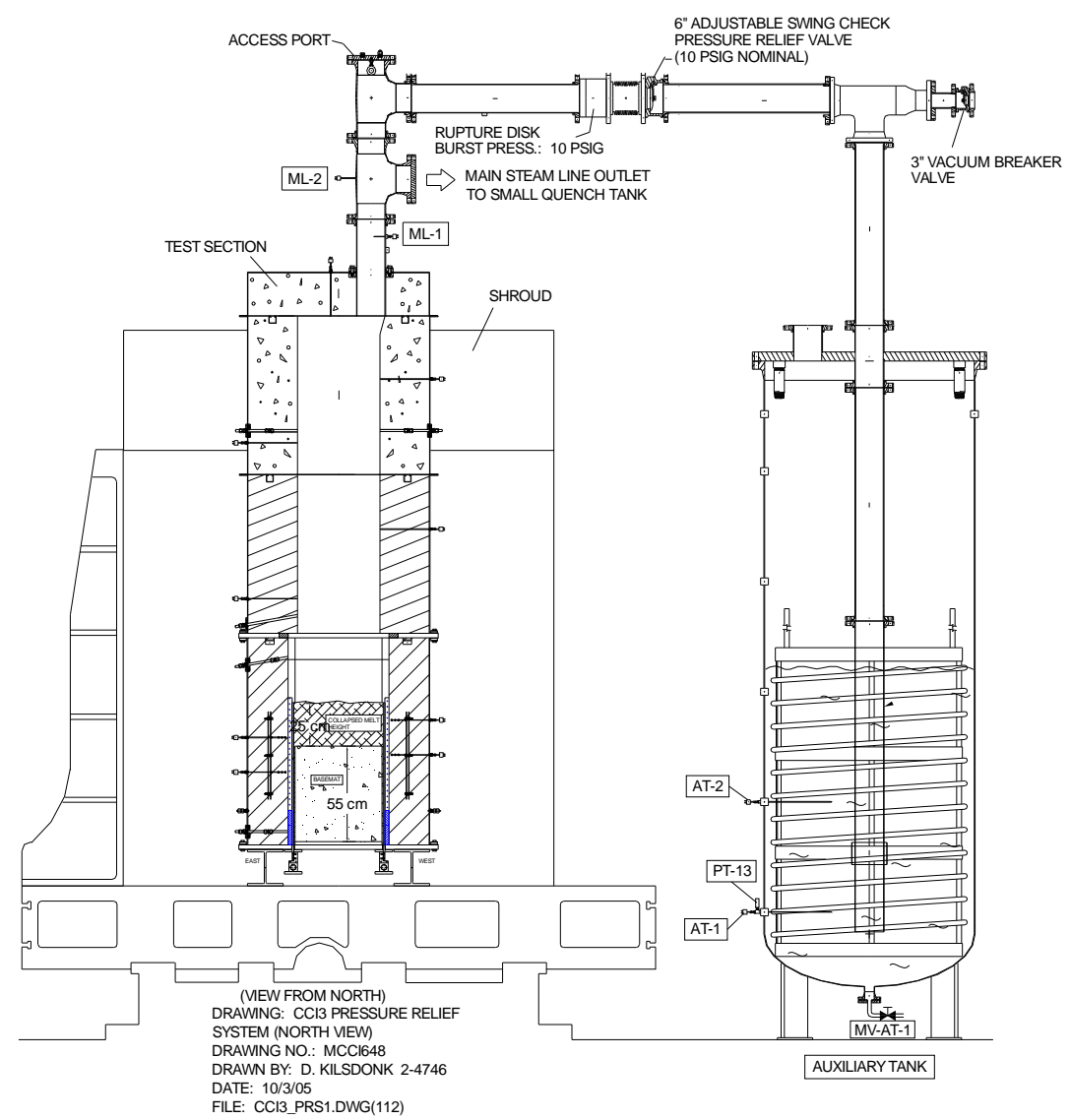

Figure 2-10. Test Section Pressure Relief System.

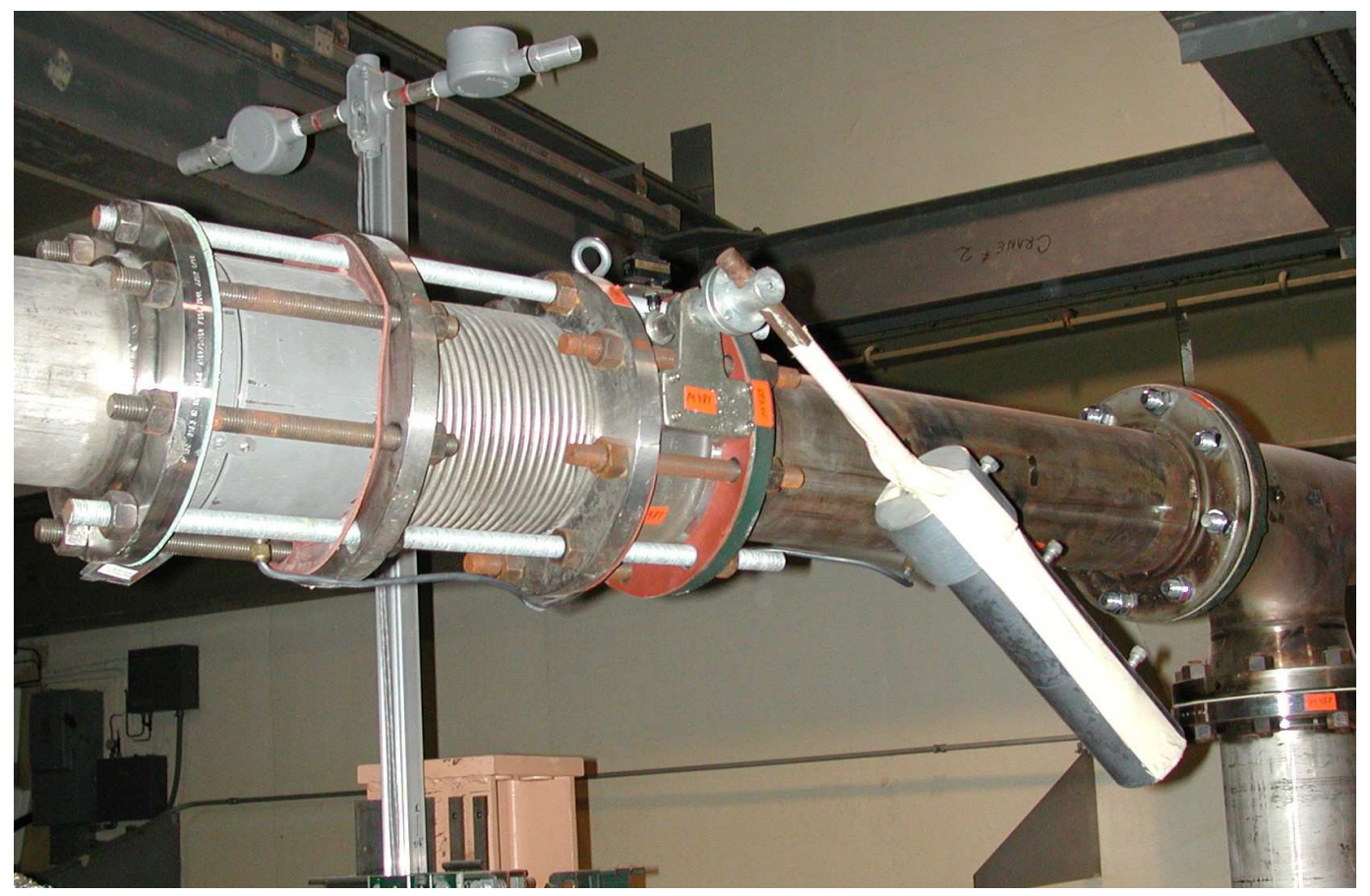

Figure 2-11. Photograph of Rupture Disk and Counter-Weighted Check Valve Assembly. 
Detailed plan and elevation views of the basemat thermocouple layout are provided in Figures 2-12 and 2-13, respectively, while the concrete sidewall instrumentation locations are shown in Figures 2-4 and 2-14. Both the basemat and sidewall were instrumented with multijunction Type $\mathrm{K}$ thermocouple assemblies to determine the 2-D ablation profile as a function of time. In addition, Type $\mathrm{C}$ thermocouple assemblies in tungsten thermowells protruded upwards from the basemat and laterally inwards from the concrete sidewall in several locations. The purpose of these instruments was to provide data on the axial and lateral melt temperature distribution as a function of time. Note that the thermocouple junction locations were repositioned to provide melt temperature and ablation front location data over the increased range of lateral and axial concrete ablation that was designed into this experiment. The concrete instrumentation layout was similar to CCI-3, with the exception that additional thermocouples were added on both sides of the concrete sidewall centerline at several axial elevations to provide additional data on the radial ablation progression; locations are detailed in Figure 2-14.

Other significant test instrumentation included a stationary (lid mounted) video camera for observing physical characteristics of the core-concrete interaction. In addition, a two-color optical pyrometer was added to measure the debris upper surface temperature during periods in which aerosol production did not optically occlude the view of the surface.

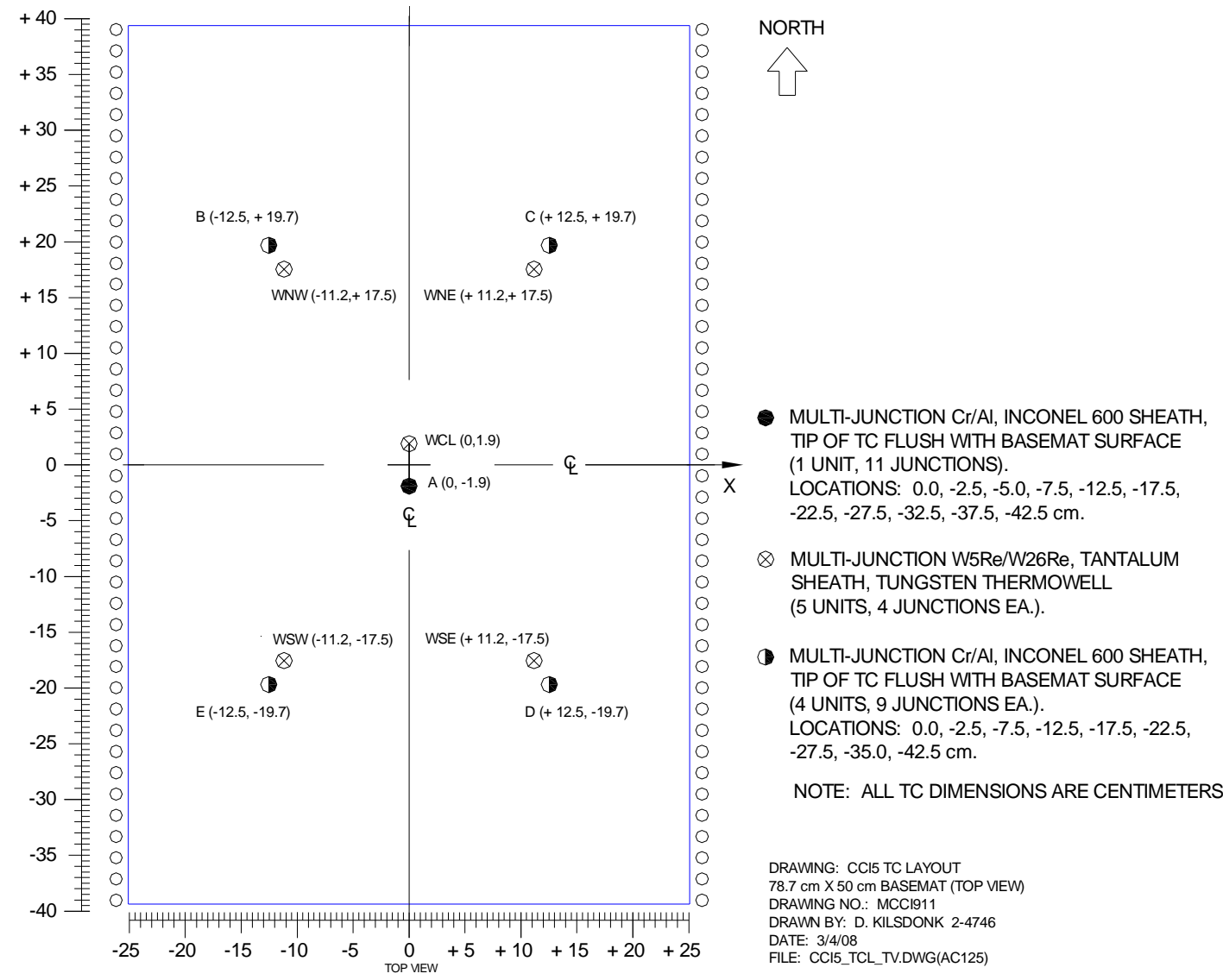

Figure 2-12. Plan View of Basemat Instrumentation Layout (dimensions are in cm). 
OECD/MCCI-2009-TR06 Rev. 1

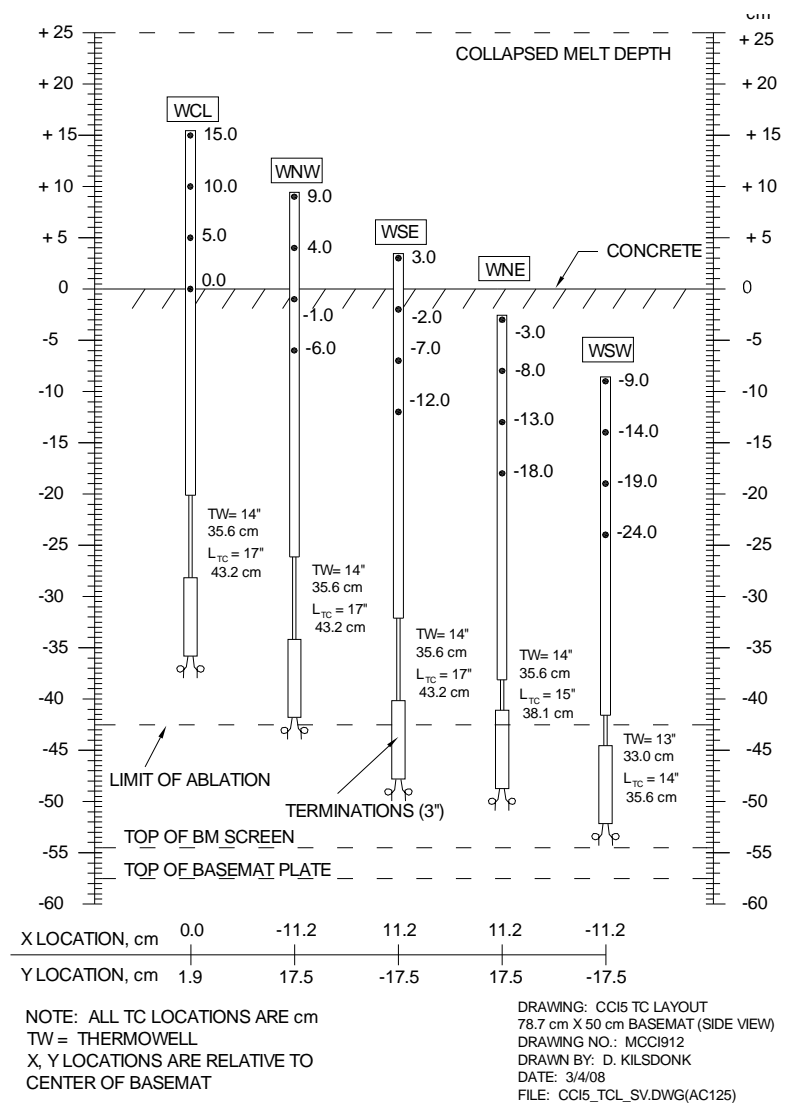

Figure 2-13. Elevation View of Basemat Type C Thermocouple Locations.

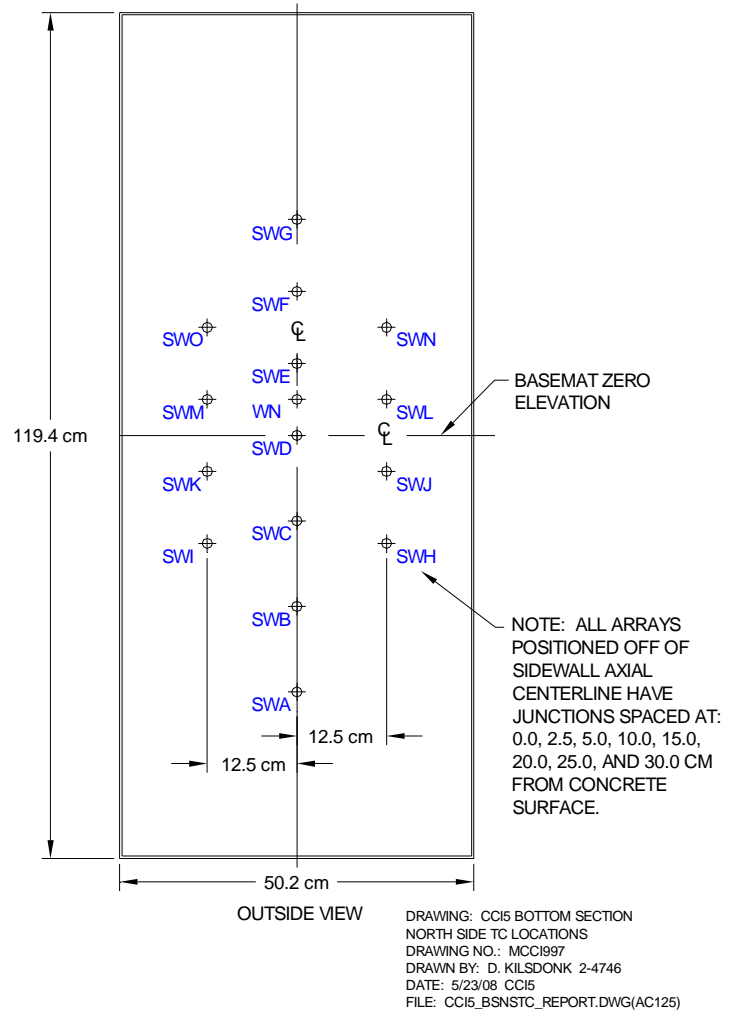

Figure 2-14. Exterior View of Concrete Sidewall Form Showing Instrument Locations. 
All data acquisition and process control tasks were managed by a PC executing LabVIEW 8.4 under Windows XP. Sensor output terminals were connected inside the test cell to model HP E1345A 16-channel multiplexers that were integrated into a mainframe chassis in groups of eight. An illustration of the DAS setup is provided in Figure 2-15. The multiplexers directed signals to an HP E1326B 5 1/2 digit multimeter incorporated into each chassis. Three independent 128 channel systems were used for a total capacity of 384 channels.

Signal noise was reduced by the digitizer through integration over a single power line cycle $(16.7 \mathrm{~ms})$. The digitized sensor readings were routed from the test cell to the PC in the control room via two HP-IB extenders. The extenders allowed the ASCII data from the HP to be sent through the cell wall over a BNC cable. The extender within the control room then communicated with a GPIB card within the PC. This configuration also permitted remote control of the multimeter through LabVIEW.

Integration of the signal over the period of a power line cycle limited the speed with which the multiplexer could scan the channel list. The minimum time for the digitizer to scan the channel list was $\sim 1.7$ s (i.e., $16.7 \mathrm{~ms} \bullet 100$ channels/chassis for this test). Though the three systems operated independently, implying the ability to update all 300 channels in roughly two seconds, the actual time required for the update was about $5.5 \mathrm{~s}$.

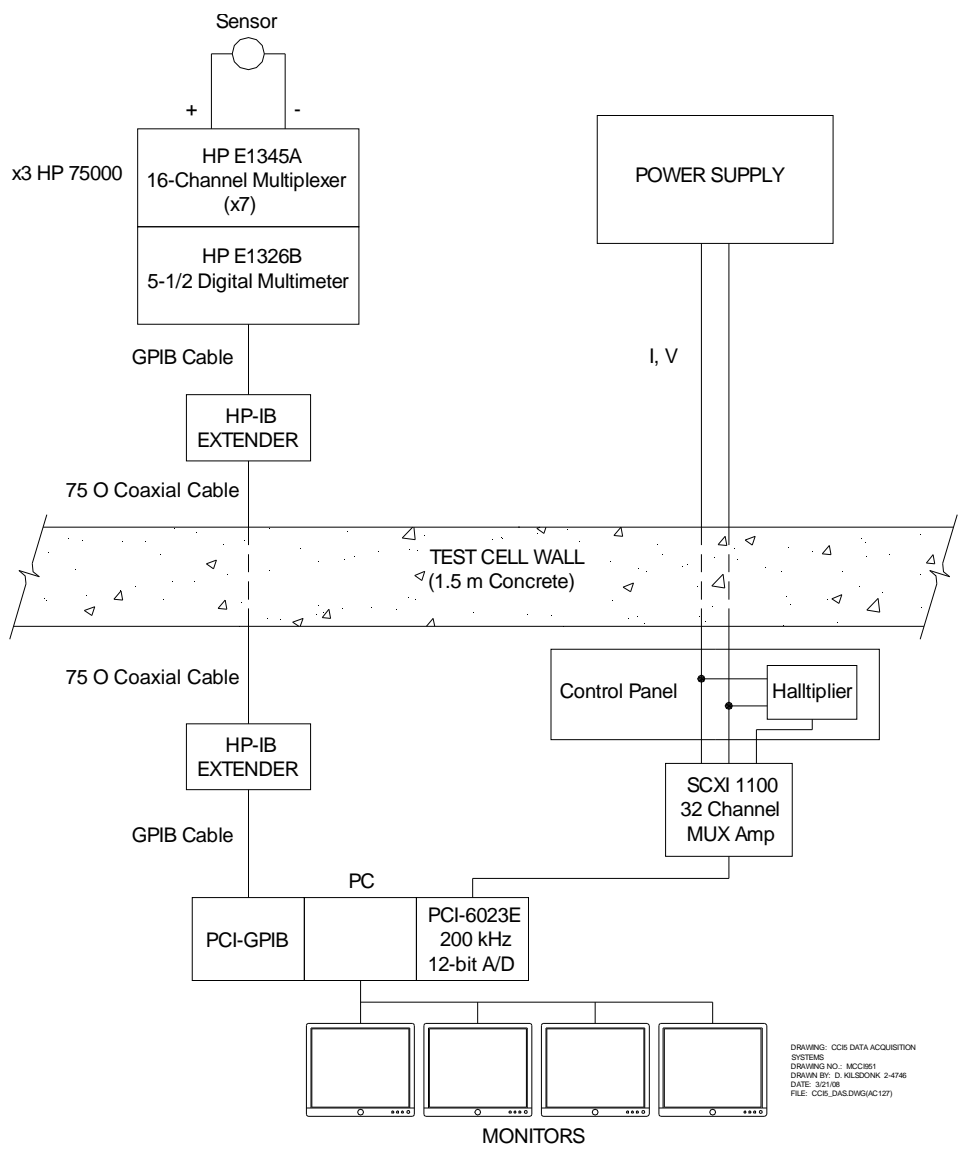

Figure 2-15. CCI Data Acquisition and Control Systems. 


\subsection{Corium Composition}

As shown in Table 1-1, the corium oxide phase composition for CCI-5 was specified to contain $15 \mathrm{wt} \%$ calcined siliceous concrete as an initial constituent. As part of the developmental work for the SSWICS-6 and CCI-3 experiments, a specific thermite was developed to produce this particular melt composition. The thermite reaction was of the form:

$$
\begin{gathered}
1.22 \mathrm{U}_{3} \mathrm{O}_{8}+3.3 \mathrm{Zr}+0.978 \mathrm{Si}+2.282 \mathrm{SiO}_{2}+0.05 \mathrm{Mg}+0.69 \mathrm{CaO}+0.055 \mathrm{Al}+2.165 \mathrm{CrO}_{3} \rightarrow \\
3.66 \mathrm{UO}_{2}+3.3 \mathrm{ZrO}_{2}+3.26 \mathrm{SiO}_{2}+0.05 \mathrm{MgO}+0.69 \mathrm{CaO}+0.11 \mathrm{Al}_{2} \mathrm{O}_{3}+2.165 \mathrm{Cr} \\
\mathrm{Q}=-228.17 \mathrm{~kJ} / \mathrm{mole}(1.721 \mathrm{MJ} / \mathrm{kg}) ; \\
\mathrm{T}_{\text {adiabatic }}=2504{ }^{\circ} \mathrm{C} ; \mathrm{T}_{\text {actual }} \sim 1950{ }^{\circ} \mathrm{C}
\end{gathered}
$$

The composition of the melt produced from this reaction is summarized in Table 2-1, while the detailed pre- and post-reaction compositions are provided in Table 2-2. Note that the pre- and post-reaction compositions shown in these tables do not include the additional mass of crushed $\mathrm{UO}_{2}$ pellets that were used to line the test section $\mathrm{MgO}$ sidewalls. Experience had shown that this material did not participate in the initial exothermic chemical reaction, and remained essentially intact as a protective layer during the ensuing core-concrete interaction. The actual mass of $\mathrm{UO}_{2}$ that dissolved into the melt over the course of the experiment was determined as part of the posttest examination activities.

The thermite powders were packed into the test section in a large, 1.7 mil aluminized Saran bag that was pre-installed over the basemat to prevent water absorption by $\mathrm{CrO}_{3}$ and concrete oxides (principally $\mathrm{CaO}$ and $\mathrm{SiO}_{2}$ ), since these constituents are hygroscopic. As an additional measure to prevent moisture infiltration into the thermite from the concrete, the basemat and sidewalls were completely covered with continuous sheets of Saran film before thermite loading.

\subsection{Concrete Composition}

As shown in Table 1-1, the composition of the CCI-5 concrete basemat and sidewalls is specified to be of the siliceous type. The engineering composition for this particular concrete is shown in Table 2-3. The sand and aggregate for the mix were supplied by CEA as an in-kind contribution to the program. The chemical composition of this concrete is shown in Table 2-3. The composition was determined ${ }^{1}$ based on chemical analysis of the archive sample that was produced when the components for this test were poured.

To prevent downward migration and possible escape of concrete decomposition gases during the course of the experiment, the electrode penetrations through the bottom support plate were sealed using O-rings. As described in the next section, the test section was leak checked at $83 \mathrm{kPa}$ differential pressure as part of pretest operations to verify a low leak rate. On this basis, essentially all concrete decomposition gases migrated upwards through the melt pool during the experiment, as opposed to partial loss through the bottom support plate of the apparatus. Reinforcing rod was eliminated so that it did not mask or delay the attainment of a fully oxidized

\footnotetext{
${ }^{1}$ Chemical analysis carried out by the Construction Technologies Laboratories (CTL Group) in Skokie, Illinois.
} 
melt. In previous tests, the concrete surfaces were protected by a layer $3 \mathrm{~mm}$ thick layer of $\mathrm{ZrO}_{2}$ felt insulation to prevent thermal shock of the concrete basemat and sidewalls during the initial exothermic chemical reaction. However, for CCI-5 this insulation was omitted in order to minimize the time to onset of concrete ablation after the thermite burn was completed.

The density of the siliceous concrete was $\sim 2382 \mathrm{~kg} / \mathrm{m}^{3}$, which was calculated based on the measured mass and volume of the CCI-5 concrete archive sample.

Table 2-1. Post-Reaction Bulk Composition for CCI-5 Thermite.

\begin{tabular}{|c|c|}
\hline Constituent & Wt\% \\
\hline $\mathrm{UO}_{2}$ & 56.32 \\
\hline $\mathrm{ZrO}_{2}$ & 23.13 \\
\hline Calcined Concrete & $14.14^{\mathrm{a}}$ \\
\hline $\mathrm{Cr}$ & 6.41 \\
\hline
\end{tabular}

${ }^{\mathrm{a}} \mathrm{Calcined}$ siliceous concrete, consisting of $79.0 / 0.9 / 15.6 / 4.5 \mathrm{wt} \% \mathrm{SiO}_{2} / \mathrm{MgO} / \mathrm{CaO} / \mathrm{Al}_{2} \mathrm{O}_{3}$

Table 2-2. Detailed Pre- and Post-Reaction Compositions for CCI-5 Thermite.

\begin{tabular}{|c|c|c|c|c|}
\hline \multirow{2}{*}{ Constituent } & \multicolumn{2}{|c|}{ Reactant } & \multicolumn{2}{c|}{ Product } \\
\cline { 2 - 5 } & $\mathbf{W t} \%$ & Mass, kg & Wt \% & Mass, kg \\
\hline $\mathrm{U}_{3} \mathrm{O}_{8}$ & 58.70 & 346.33 & - & - \\
\hline $\mathrm{UO}_{2}$ & - & - & 56.32 & 332.29 \\
\hline $\mathrm{Zr}$ & 17.16 & 101.24 & - & - \\
\hline $\mathrm{ZrO}_{2}$ & - & - & 23.13 & 136.47 \\
\hline $\mathrm{Si}$ & 1.57 & 9.26 & - & - \\
\hline $\mathrm{SiO}_{2}$ & 7.84 & 46.26 & 11.17 & 65.90 \\
\hline $\mathrm{Mg}$ & 0.07 & 0.41 & - & - \\
\hline $\mathrm{MgO}$ & - & - & 0.12 & 0.70 \\
\hline $\mathrm{Al}$ & 0.09 & 0.53 & - & - \\
\hline $\mathrm{Al}{ }_{2} \mathrm{O}_{3}$ & - & - & 0.64 & 3.78 \\
\hline $\mathrm{CaO}$ & 2.21 & 13.04 & 2.21 & 13.04 \\
\hline $\mathrm{CrO}$ & 12.36 & 72.93 & - & - \\
\hline $\mathrm{Cr}$ & - & - & 6.41 & 37.82 \\
\hline $\mathrm{Total}$ & 100.00 & 590.00 & 100.00 & 590.00 \\
\hline
\end{tabular}

Table 2-3. Engineering Composition of CCI-5 Siliceous Concrete Basemat and Sidewall.

\begin{tabular}{|c|c|c|}
\hline Constituent & wt \% & Size Distribution \\
\hline Aggregate & 47.4 & $5-8 \mathrm{~mm}: 16.6 \mathrm{wt} \%$ \\
& & $8-11 \mathrm{~mm}: 20.4 \mathrm{wt} \%$ \\
& & $11-16 \mathrm{~mm}: 10.4 \mathrm{wt} \%$ \\
\hline Sand & 30.6 & $0-2 \mathrm{~mm}: 12.2 \mathrm{wt} \%$ \\
& & $2-4 \mathrm{~mm}: 18.4 \mathrm{wt} \%$ \\
\hline Type 1 Cement & 15.3 & N/A \\
\hline Tap Water & 6.7 & N/A \\
\hline
\end{tabular}


Table 2-4. Chemical Composition of Siliceous Concrete.

\begin{tabular}{|c|c|}
\hline Oxide & Wt\% \\
\hline $\mathrm{SiO}_{2}$ & 58.27 \\
\hline $\mathrm{Al}_{2} \mathrm{O}_{3}$ & 3.51 \\
\hline $\mathrm{Fe}_{2} \mathrm{O}_{3}$ & 1.33 \\
\hline $\mathrm{CaO}$ & 20.20 \\
\hline $\mathrm{MgO}$ & 0.92 \\
\hline $\mathrm{SO}_{3}$ & 0.45 \\
\hline $\mathrm{Na}_{2} \mathrm{O}$ & 0.49 \\
\hline $\mathrm{K}_{2} \mathrm{O}$ & 0.80 \\
\hline $\mathrm{TiO}_{2}$ & 0.15 \\
\hline $\mathrm{P}_{2} \mathrm{O}_{5}$ & 0.07 \\
\hline $\mathrm{Mn}_{2} \mathrm{O}_{3}$ & 0.05 \\
\hline $\mathrm{SrO}$ & 0.03 \\
\hline $\mathrm{CO}_{2}$ & 9.50 \\
\hline $\mathrm{H}_{2} \mathrm{O}$, Free & 1.90 \\
\hline $\mathrm{H}_{2} \mathrm{O}$, Bound & 2.88 \\
\hline Total & 100.54 \\
\hline
\end{tabular}

\subsection{TEST PROCEDURES}

\subsection{Pretest Operations}

Assembly of the apparatus began by installing the tungsten electrodes (126 total; 63 per side) into machined copper electrode clamps. The electrode clamps were then attached to the bottom of the $2.54 \mathrm{~cm}$ thick aluminum support plate which served as the foundation for the entire apparatus. With the electrode clamps installed, the support plate was moved into position on the ZPR-9 reactor bed. The concrete basemat was then placed atop the support plate. The basemat was then completely covered with a continuous sheet of 1.7 mil aluminized Saran film to prevent moisture contamination of the thermite powders from the basemat once the powders were loaded into the test section. The lower test section concrete and $\mathrm{MgO}$ sidewalls were then set in place. The concrete sidewall was also covered with aluminized Saran before placement to prevent moisture contamination of the thermite once the powders were loaded. The lower section flange bolts and clamping bars were then installed and torqued according to an approved procedure.

In parallel with test section assembly, the thermite powders were mixed in preparation for corium loading. As a precursor for initiating mixing, a gas sample test ${ }^{\mathrm{a}}$ was conducted to verify that the initial level of volatile impurities in a sample prepared from the CCI-5 thermite constituents was sufficiently low to preclude excessive gas release during the burn. The results of this test indicated moisture content within acceptable limits. On this basis, mixing was initiated.

\footnotetext{
${ }^{\mathrm{a}}$ The gas sample test procedure consisted of igniting a representative sample of the thermite in a closed vessel. The amount of noncondensable gas produced was determined from the ideal gas law; the composition of the evolved gases was determined using gas mass spectroscopy.
} 
Once the lower section was assembled, preparations for loading of the corium charge began. A single, large 1.7 mil aluminized Saran bag was preinstalled over the basemat. During loading, the $590 \mathrm{~kg}$ thermite charge was placed within this single bag in order to minimize the amount of bagging material present in the thermite. As the powders were placed in the test section, the basemat melt temperature thermocouples were monitored to detect any localized heating in the corium powders. If heating was observed, the cell was to be evacuated immediately. As the thermite was placed, the gap between the tungsten electrodes and $\mathrm{MgO}$ sidewalls was filled with crushed $\mathrm{UO}_{2}$ pellets. A temporary sheet metal form was also designed that allowed a uniform $2.5 \mathrm{~cm}$ thick layer of crushed pellets to be installed between the corium powders and the non-heated $\mathrm{MgO}$ sidewall. The crushed pellets served as a protective layer against excessive chemical/thermal attack by the corium during the test. Once loading was completed, two sparkler igniters were placed a few centimeters below the top of the powders near the center of the test section, and then the bag was folded and sealed.

Once loading was completed, a removable train containing a $1.0 \mathrm{~kg}$ bagged sample of thermite was installed over the powder bed; an illustration is provided in Figure 3-1. The sample train was removed weekly and the sample weighed to monitor the moisture pickup by the thermite during the period between loading and test initiation. Note from Figure 3-1 that the top portion of the train also contained a $4.5 \mathrm{~kg}$ canister of desiccant. The desiccant was provided to maintain the plenum gas as dry as possible during pretest operations. As an additional measure to prevent moisture accumulation in the powder bed, the lower test section was continuously purged with argon $(2 \mathrm{slpm})$ from the time loading was completed until the test was initiated.

After installation of the sample train, the remainder of the test apparatus was assembled. This included installation of the transition plate, two upper sidewall sections, and finally the enclosure lid. Peripheral instrumentation was then installed on the lid and sidewalls of the test section. The main steamline run from the test section to the primary quench tank was completed, as well as the pressure relief line from the test section to the auxiliary tank. (The main steamline was closed off from the test section using an insertable blank-off plate throughout pretest operations to preclude moisture migration from the quench tank into the test section).

After assembly was completed, extensive system checkout procedures were performed to ensure that the facility was in proper working order. This included a proof test of the test section at $83 \mathrm{kPad}$, which was $20 \%$ in excess of the pressure relief system activation pressure of 68 $\mathrm{kPad}$. The pressurization gas for this test was argon. An insertable blind flange was installed upstream of the rupture disk in the pressure relief line to isolate this system. During the test, the apparatus was gradually pressurized to the proof pressure of $83 \mathrm{kPad}$. After a 1 minute hold at this pressure, the system was isolated to determine the leak rate. The leak rate of the CCI-5 test section was found to be $3.0 \mathrm{kPa} / \mathrm{min}(13 \mathrm{slpm})$ at a nominal pressure of $55 \mathrm{kPad}$, which was significantly below the acceptable leak rate of the fully assembled test section (i.e., $<2 \%$ of the expected peak gas/vapor generation rate during the test).

Pretest preparations for CCI-5 culminated with a final full system checkout that involved remotely running all equipment with the power supply in operation across a water cooled dummy load. Once the full system check was completed, final system preparations were carried out. These efforts included: (i) hookup of the power supply to the tungsten electrodes through water 
cooled buss bars, (ii) installation of the final piping connection between the water supply tank and the test section, and (iii) removal of the sample train from within the test section. Following connection of the power supply to the electrode clamps, the key for the power supply lockout located in the cell, as well as the key for the interlock located on the control room console, were assigned to a custodian who kept the keys in their possession until the test was initiated. This step was taken to preclude inadvertent activation of the power supply.

Over the five week time interval spanning pretest operations, the moisture content of the removable sample of bagged thermite increased gradually from $0.187 \mathrm{wt} \%$ to $0.225 \mathrm{wt} \%$. The final moisture content was within the maximum permissible level of $0.3 \mathrm{wt} \%$. On this basis, final approval was granted to proceed with the execution of Test CCI-5.

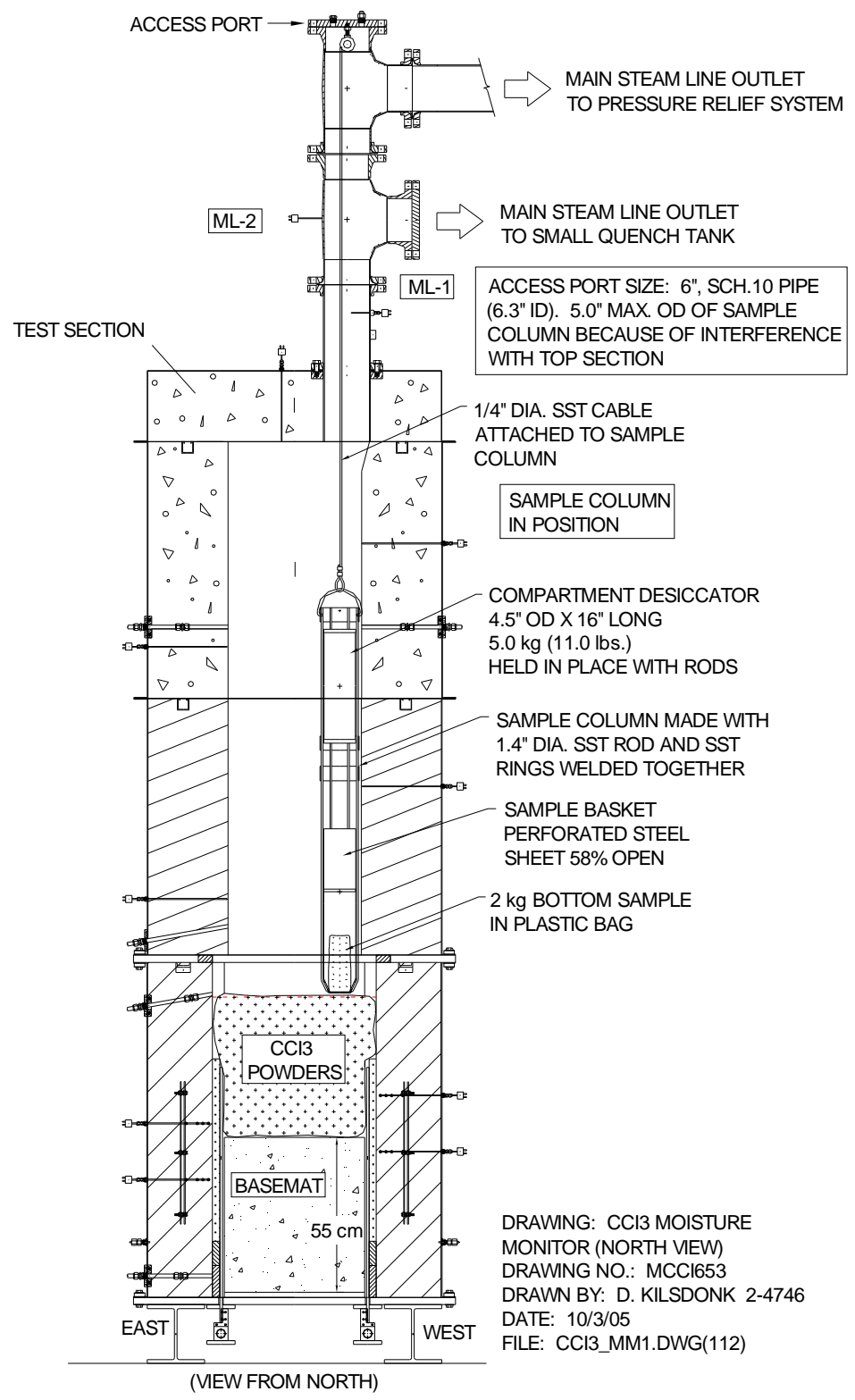

Figure 3-1. Illustration of Thermite Sample Train Installed in Test Section. 


\subsection{Test Operations}

The planned test operating procedure is described first, followed by a brief summary of the actual operating procedure.

As shown in Table 1-1, target power for the dry core-concrete interaction phase of the test was $145 \mathrm{~kW} .^{\mathrm{b}}$ After melt formation, the input power would be brought up to $145 \mathrm{~kW}$ and held there for the balance of dry cavity operations. Onset of basemat ablation would define time $\mathrm{t}=0$ for the experiment. After ablation began, the interaction would be permitted to proceed for 6.0 hours, or until the ablation depth reached $35 \mathrm{~cm}$ laterally or $37.5 \mathrm{~cm}$ axially. After one of these two criteria was met, the cavity would then be flooded. However, if a crust was present at the melt upper surface, the crust lance would be used to fail the crust prior to flooding so that the water would be able to contact the underlying melt. Following water addition, the power supply operation would be switched from constant power at $145 \mathrm{~kW}$ to a constant voltage operating mode. (With constant voltage, the input power density would remain relatively constant if a significant quench front developed). Forty five minutes after water addition, or after the debris cooling rate had been reduced to a relatively low level, the crust would be failed with the lance to obtain data on the transient crust breach cooling mechanism. After breach, power supply operation would continue for an additional 45 minutes, yielding a total operating period of 90 minutes with water present in the cavity, or until the ablation limit of $40 \mathrm{~cm}$ was reached laterally or $42.5 \mathrm{~cm}$ axially. At this point, the input power would be turned off and the test terminated.

CCI-5 was performed on 25 September 2008. On the evening prior to the experiment, the apparatus was inerted with a slow bleed of helium into the test section. On the day of the experiment, the apparatus was brought up to operating conditions, a final walk through inspection was performed by operating personnel, the thermite igniter was hooked up, and finally the power supply was energized before the containment was evacuated and sealed. Data acquisition was initiated at 5:00 pm. Coolant and cover gas flows were brought up to design conditions, and the cell ventilation system was closed and sealed per test procedures.

The event sequence for CCI-5 is provided in Table 3-1. In the discussion that follows, time $\mathrm{t}=0$ corresponds to the onset of basemat ablation. The criterion used to define the onset of concrete ablation at a given location was that the local temperature reached the siliceous concrete liquidus temperature of $1250^{\circ} \mathrm{C}$. [5]

As shown in Table 3-1, data acquisition began at -6.0 minutes relative to initial melt contact with the concrete basemat. As shown in Figure 3-2, power was applied to the nichrome wire/sparkler located at the top of the powder charge at -1.2 minutes. Based on video camera data from the test section and plenum gas temperature readings inside the test section, thermite ignition was announced and logged in the control room at -0.9 minutes. Based on readings from thermocouples located near the top of the concrete, the burn front reached the bottom of the powder bed in $\sim 40$ seconds (i.e., at -0.3 minutes), which was within the planning basis for the experiment. The readings from selected melt temperature thermocouples are shown in Figure 33 over the first few minutes of the interaction. As is evident from this collection of data, peak

\footnotetext{
${ }^{\mathrm{b}}$ The $145 \mathrm{~kW}$ power level for CCI-5 is based on the requirement of providing an initial 'prototypic' heat flux of $160 \mathrm{~kW} / \mathrm{m}^{2}$ across all melt surfaces that are not in contact with insulating sidewall material.
} 
melt temperatures near the center of the melt in the first 30 seconds of the interaction were in the range of 1930 to $1970{ }^{\circ} \mathrm{C}$, with the average value being $\sim 1950{ }^{\circ} \mathrm{C}$.

Table 3-1. CCI-5 Event Sequence (times relative to onset of cavity ablation).

\begin{tabular}{|c|c|}
\hline $\begin{array}{l}\text { Time } \\
\text { (Minutes) }\end{array}$ & Event \\
\hline-6.0 & DAS started. \\
\hline-1.2 & Power applied to thermite igniter wire. \\
\hline-0.9 & Thermite burn initiated; view of melt surface occluded by aerosol within 5 seconds. \\
\hline-0.3 & Thermite burn completed (burn time $\sim 40$ seconds); melt temperature $\sim 1950{ }^{\circ} \mathrm{C}$ \\
\hline 0.0 & $\begin{array}{l}\text { Onset of ablation detected at all five basemat and all five sidewall TC array locations } \\
\text { initially contacted by melt; average time for onset is } 0.0 \text { minutes, which defined time } \mathrm{t} \\
=0 \text { for the experiment. Standard deviation in time spread is } 0.14 \text { minutes. Hereafter, } \\
\text { there were local spatial variations, but on average axial ablation proceeds slowly but } \\
\text { steadily at } \sim 3 \mathrm{~cm} / \text { hour. }\end{array}$ \\
\hline 1.9 & Target DEH input power of $145 \mathrm{~kW}$ reached. \\
\hline $3.5-49.0$ & Melt surface view effectively blocked by aerosols generated by the CCI. \\
\hline $1.4-10.2$ & $\begin{array}{l}\text { Test section pressure steadily increases from } 1.14 \text { to } 1.62 \text { Bar at which point test } \\
\text { section pressure relief system activated. }\end{array}$ \\
\hline 40.7 & Tap change from 56 to 112 Volt range on the power supply. \\
\hline $49.0-54.0$ & $\begin{array}{l}\text { Aerosols in plenum gradually cleared to reveal the interaction. Melt surface was crust } \\
\text { free and highly agitated by sparging gases. Melt surface continued to heat up until the } \\
\text { view was lost due to excessive light intensity (through a No. } 4 \text { filter). View of surface } \\
\text { not recovered until } \sim 178 \text { minutes. }\end{array}$ \\
\hline $44.0-76.0$ & $\begin{array}{l}\text { Bulk melt temperature measurements were scattered, but average value rises from } ~ \\
1710 \text { to } \sim 1780{ }^{\circ} \mathrm{C} \text { over this interval, while melt surface temperature rises from } 850 \text { to } \\
1767{ }^{\circ} \mathrm{C} \text { at the same time. }\end{array}$ \\
\hline 158.0 & $\begin{array}{l}\text { Sidewall ablation suddenly increases and remains fairly steady over the balance of the } \\
\text { experiment. Average rate is } \sim 10 \mathrm{~cm} / \text { hour. }\end{array}$ \\
\hline $171.3-199.0$ & $\begin{array}{l}\text { Test section pressure relief system activates, causing test section pressure to drop } \\
\text { gradually from } 1.7 \text { to } 1.28 \text { Bar over this time interval before settling out. }\end{array}$ \\
\hline $178.0-280.0$ & $\begin{array}{l}\text { Melt surface video showed predominately a molten surface, but crust segments } \\
\text { periodically formed on sidewalls, broke, and were mixed in with melt. }\end{array}$ \\
\hline $259-271.4$ & $\begin{array}{l}\text { Pyrometer measured steady surface temperature decline from } 1513{ }^{\circ} \mathrm{C} \text { to } 1250{ }^{\circ} \mathrm{C} \text {, } \\
\text { before rebounding suddenly back to } 1515{ }^{\circ} \mathrm{C} \text {. During this time, crust grew to cover } \\
\text { surface except for a small pocket in NW corner. At } 269 \text { minutes, melt began to flow } \\
\text { over the crust. At } 269.2 \text { minutes, large crust segments gradually broke off and were } \\
\text { mixed into the bulk, and by } 269.5 \text { most of surface was crust-free. }\end{array}$ \\
\hline 257.7 & $\begin{array}{l}\text { Crust lance inserted to break crust; minimal force was required to puncture the } \\
\text { material. }\end{array}$ \\
\hline 275.4 & $\begin{array}{l}\text { South } \mathrm{MgO} \text { sidewall surface temperature reached } 1230{ }^{\circ} \mathrm{C} \text { at the }+10 \mathrm{~cm} \text { elevation. } \\
\text { Decision made to terminate the test on the basis of excessive sidewall heatup. }\end{array}$ \\
\hline 280.8 & $\begin{array}{l}\text { Input power to melt terminated. Average input power over the time interval from } 0 \text { to } \\
280.8 \text { minutes was } 143.8 \mathrm{~kW} \text {. Peak axial ablation depth was } 22.5 \mathrm{~cm} \text {, while peak } \\
\text { radial ablation was } 30 \mathrm{~cm} \text {. }\end{array}$ \\
\hline 927.8 & Data acquisition terminated. \\
\hline
\end{tabular}


OECD/MCCI-2009-TR06 Rev. 1

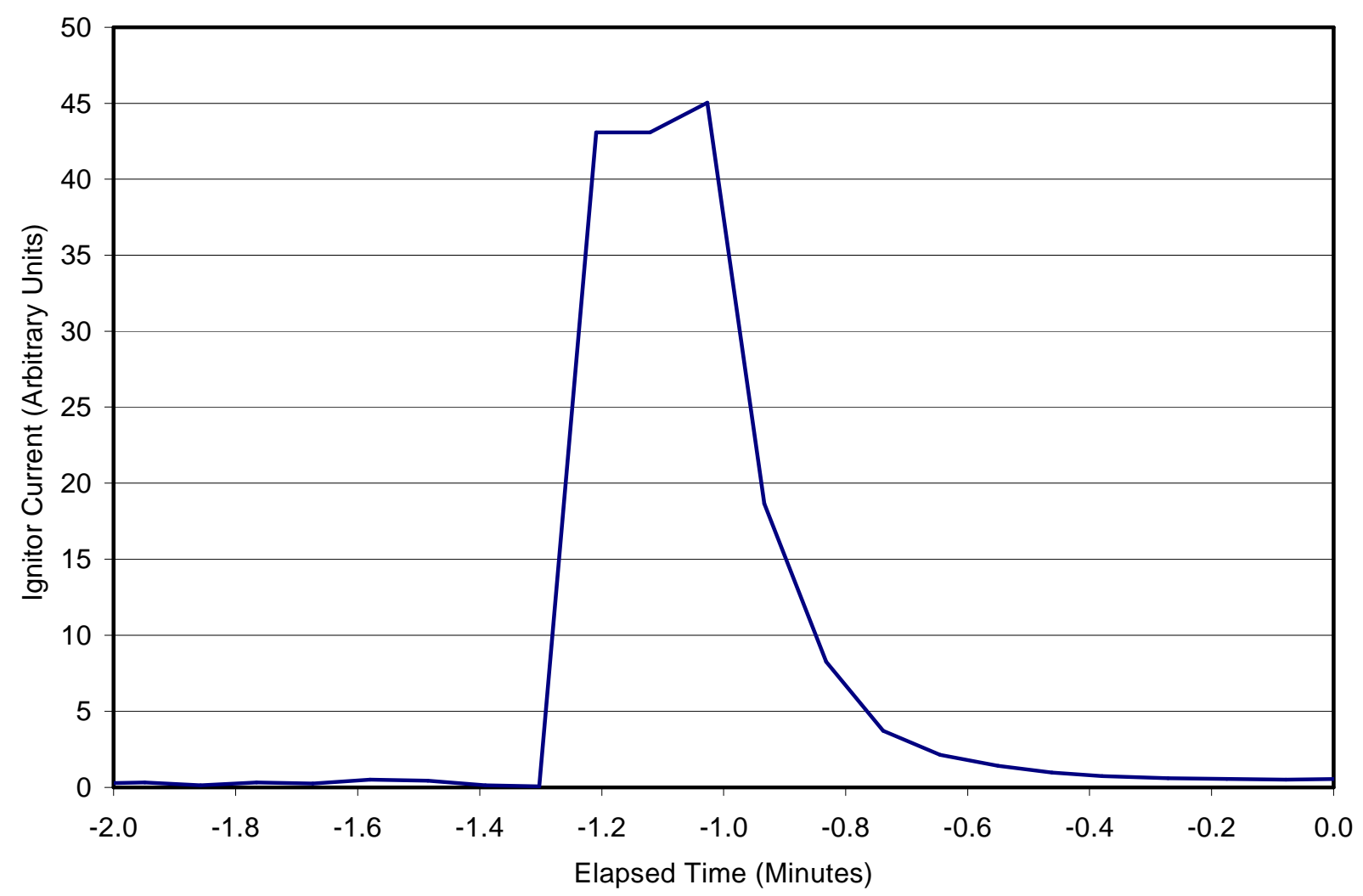

Figure 3-2. Voltage Reading Across Thermite Igniter Shunt.

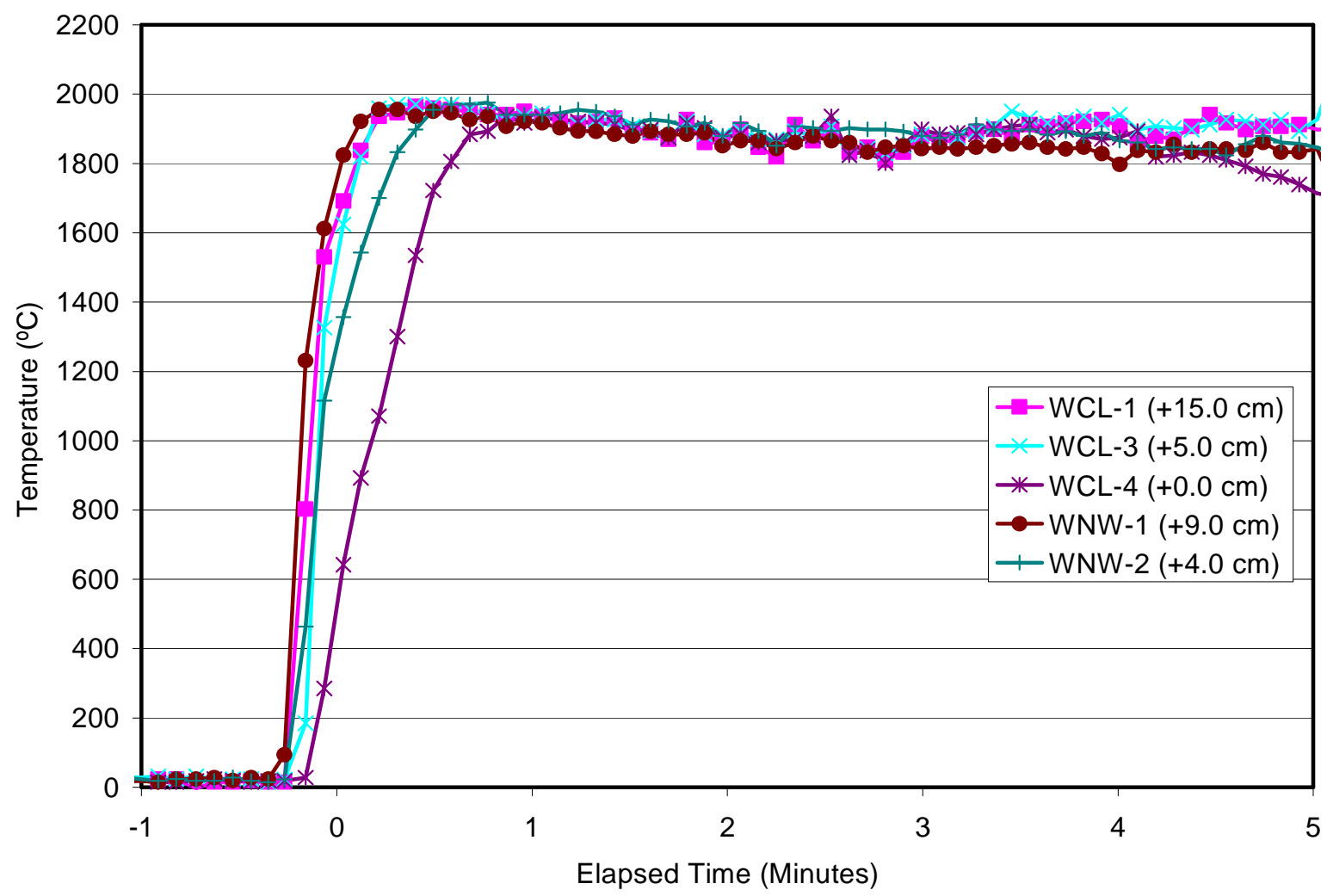

Figure 3-3. Bulk Melt Temperature Data over the First 5 Minutes of the Interaction. 
Soon after the thermite burn was completed, onset of ablation was detected at all five basemat and all five sidewall thermocouple (TC) array locations initially contacted by melt; average time for ablation onset was 0.0 minutes, which defines time $t=0$ for the experiment. The standard deviation in time spread for onset of ablation is 0.14 minutes. Thereafter, although there were local variations, axial ablation proceeded slowly but steadily at a rate of $\sim 3 \mathrm{~cm} / \mathrm{hour}$, while onset of radial ablation was delayed until later in the experiment sequence.

At completion of the burn, a power supply current ramp up to the target power of $145 \mathrm{~kW}$ was initiated. This power level was reached at 1.9 minutes, where it was maintained for the balance of the test. A power supply voltage tap change was made at 40.7 minutes to accommodate the increased voltage required to maintain constant power input as the melt resistance increased (due to incorporation of concrete slag into the melt). Over the time interval from 1.4 to 10.2 minutes, the pressure in the test section steadily increased. The test data, as well as posttest examinations, indicated that this occurred due to plugging of the final off-gas flowmeter by aerosols that were entrained through the system during the thermite burn. The test section pressure is shown in Figure 3-4, while the quench and spray tank pressures are shown in Figure 3-5. In addition, a photograph of the aerosol that plugged the inlet to the gas flowmeter is shown in Figure 3-6. As indicated in Figure 3-4, the pressure in the test section gradually increased from 1.14 to 1.62 Bar over the time interval from 1.4 to 10.2 minutes, at which time the pressure suddenly decreased to 1.36 Bar. This sudden reduction was most likely caused by activation of the rupture disk in the test section pressure relieve system; the rupture disk was rated for $68 \pm 13 \mathrm{kPad}$. The data also indicates that the counter-weighted check valve (Figures 210 and 2-11) subsequently reset, causing the pressure in the test section to gradually rise again. The pressure hovered in the range of 1.36 to 1.7 Bar until 171.3 minutes, at which point the check valve appears to have reopened, and remained that way during the balance of the test. This occurrence was most likely due to a large increase in noncondensable gas flow associated with the onset of sidewall ablation at 158 minutes (Table 3-1), after which point the sidewall ablation rate remained fairly steady at $\sim 10 \mathrm{~cm} /$ hour. The fact that the pressure relief line remained open after 171 minutes was verified by the sustained heatup of the water inventory in the auxiliary tank past this time; see Figure 3-7. This response also indicated that there was little flow bypass through the pressure relief system in the time interval following initial rupture disk failure (at 10.2 minutes) up to the time that the relief line reopened (at 171 minutes).

As the experiment progressed, the lower test section $\mathrm{MgO}$ sidewalls continued to heat up due to convection from the melt. The most intense thermal loading occurred on the south $\mathrm{MgO}$ sidewall opposite from the concrete sidewall undergoing ablation. The thermal response in this wall at the $+10.0 \mathrm{~cm}$ elevation is shown in Figure 3-8. The temperature near the surface in this wall reached $1230{ }^{\circ} \mathrm{C}$ at 275.4 minutes. The decision was then made to terminate the test on the basis of excessive sidewall heatup. Input power to the melt was subsequently terminated at 280.8 minutes. Peak axial ablation depth was $22.5 \mathrm{~cm}$ at this time, while the peak radial ablation was $30.0 \mathrm{~cm}$. The cavity was not flooded due to the concern that, with the plugged offgas system, the resultant steam spike could lead to gross failure of the test section. Data logging continued overnight, and the DAS was subsequently turned off at 927.8 minutes. 


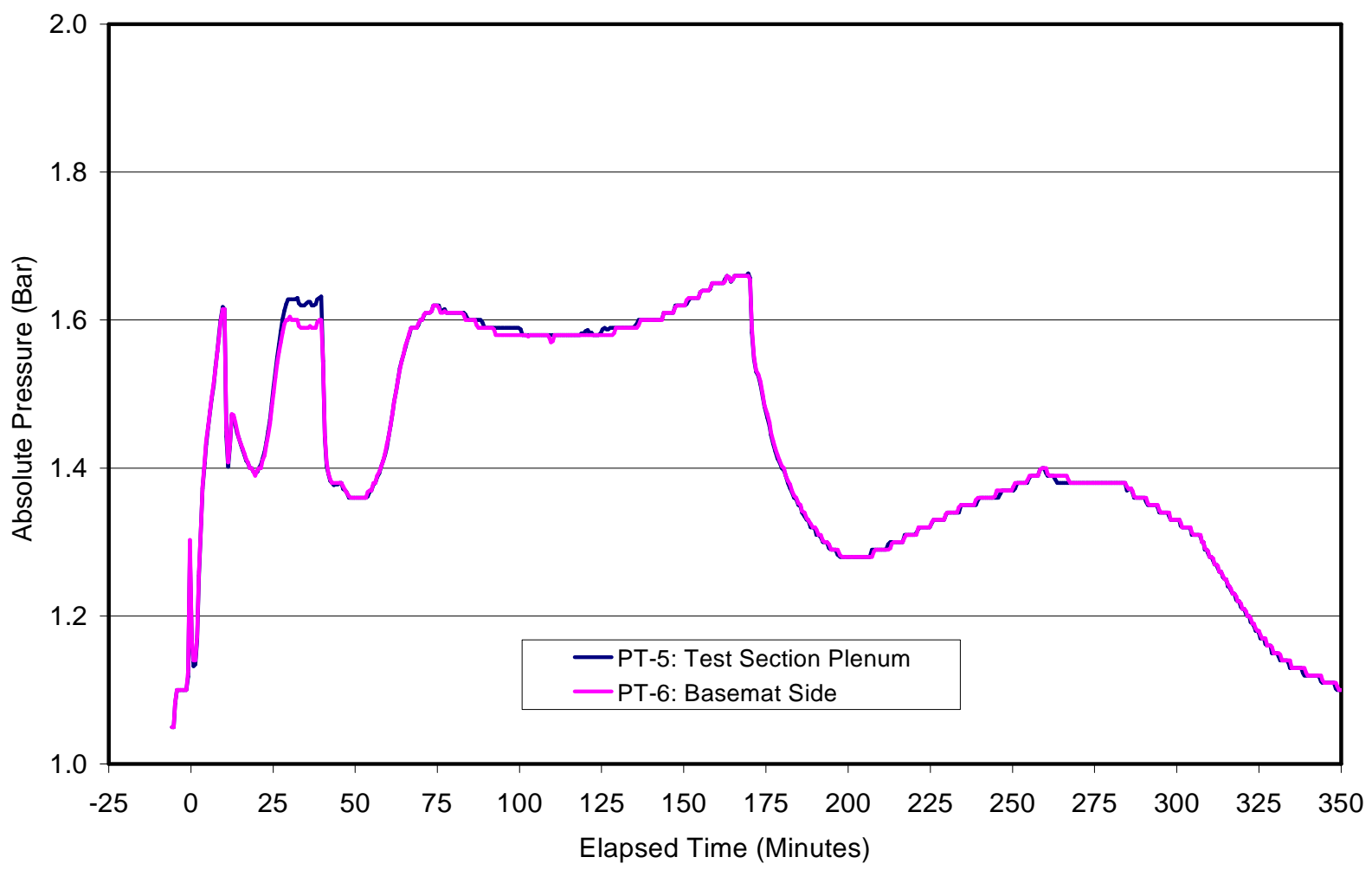

Figure 3-4. Test Section Pressure Response.

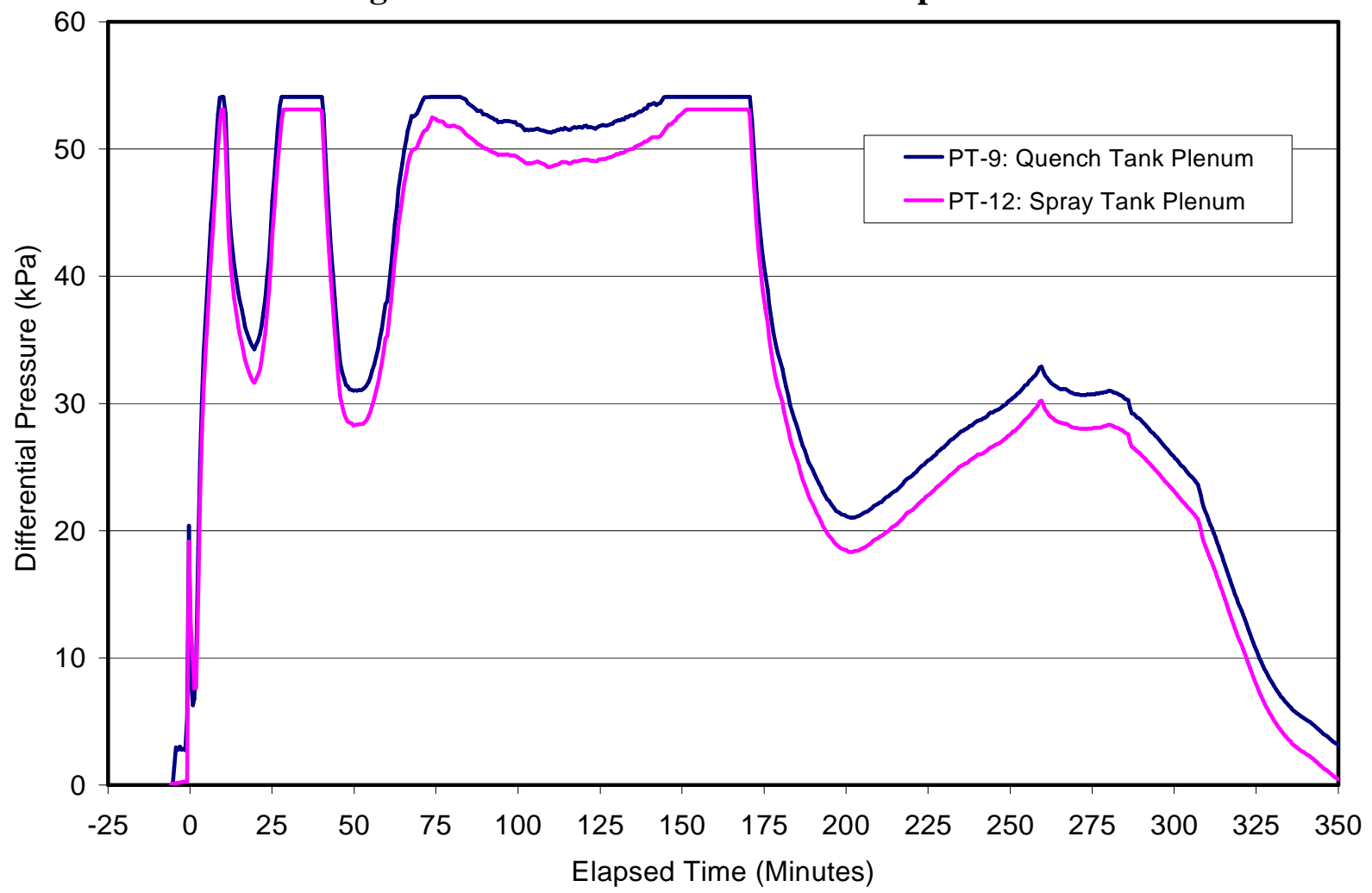

Figure 3-5. Quench System Tank Differential Pressure Responses (the range of these units is $0-35 \mathrm{kPad}$, and they clip at $\sim 55 \mathrm{kPad})$. 
OECD/MCCI-2009-TR06 Rev. 1

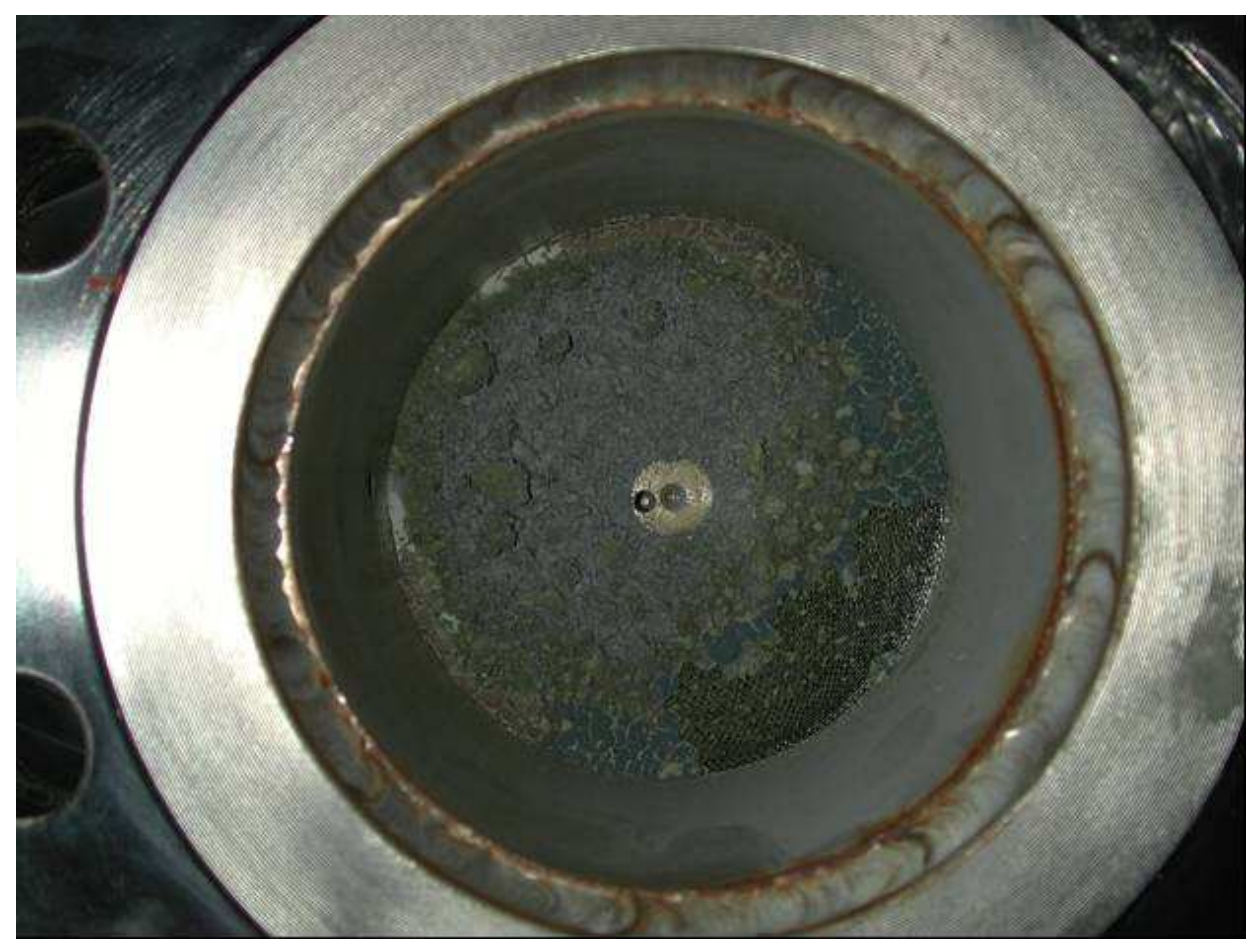

Figure 3-6. Photo of Aerosol Plugging of Offgas Flowmeter Inlet (pipe ID is $10 \mathrm{~cm}$ ).

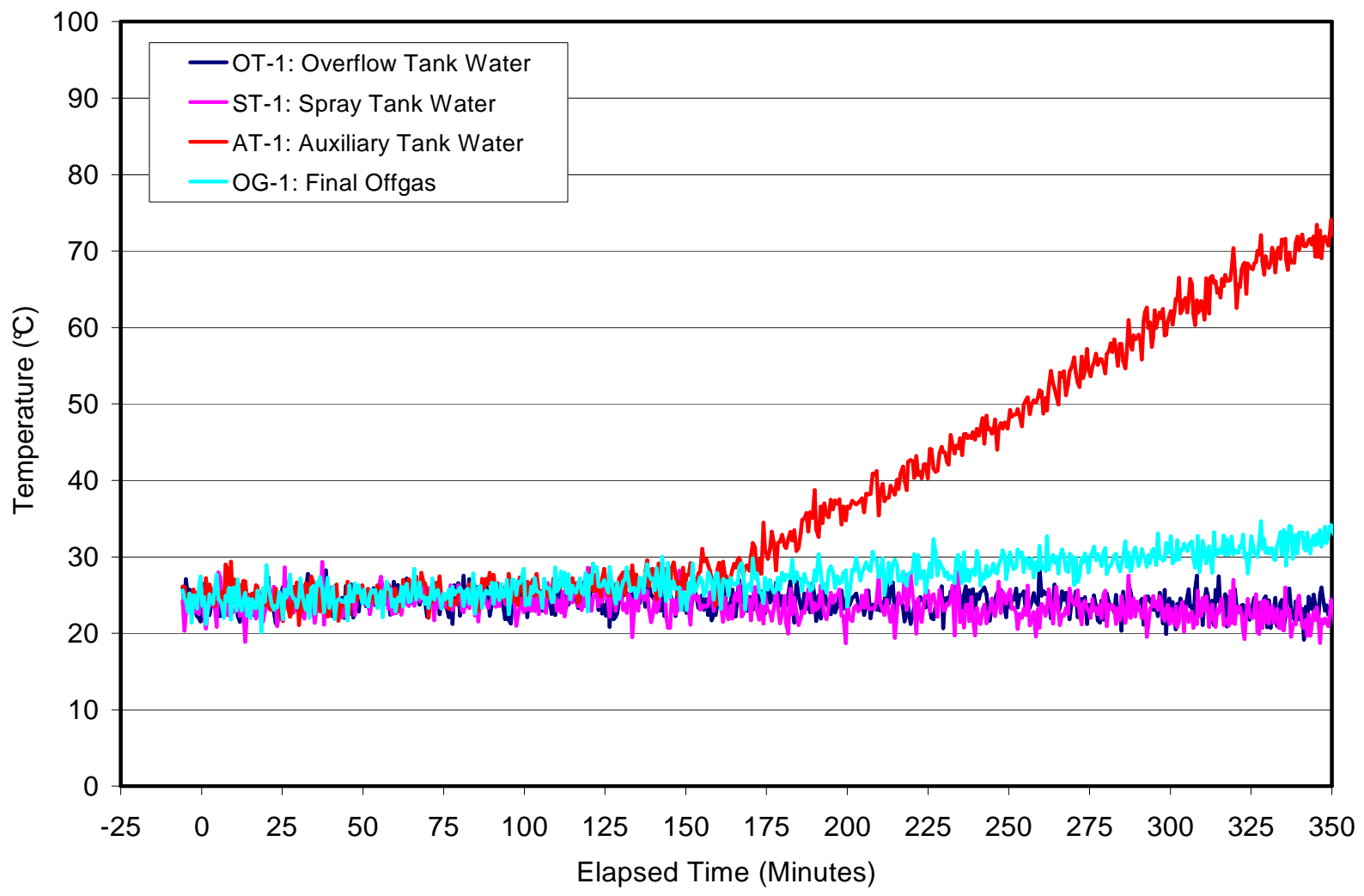

Figure 3-7. Miscellaneous Temperatures in Quench and Off-Gas Systems. 
OECD/MCCI-2009-TR06 Rev. 1

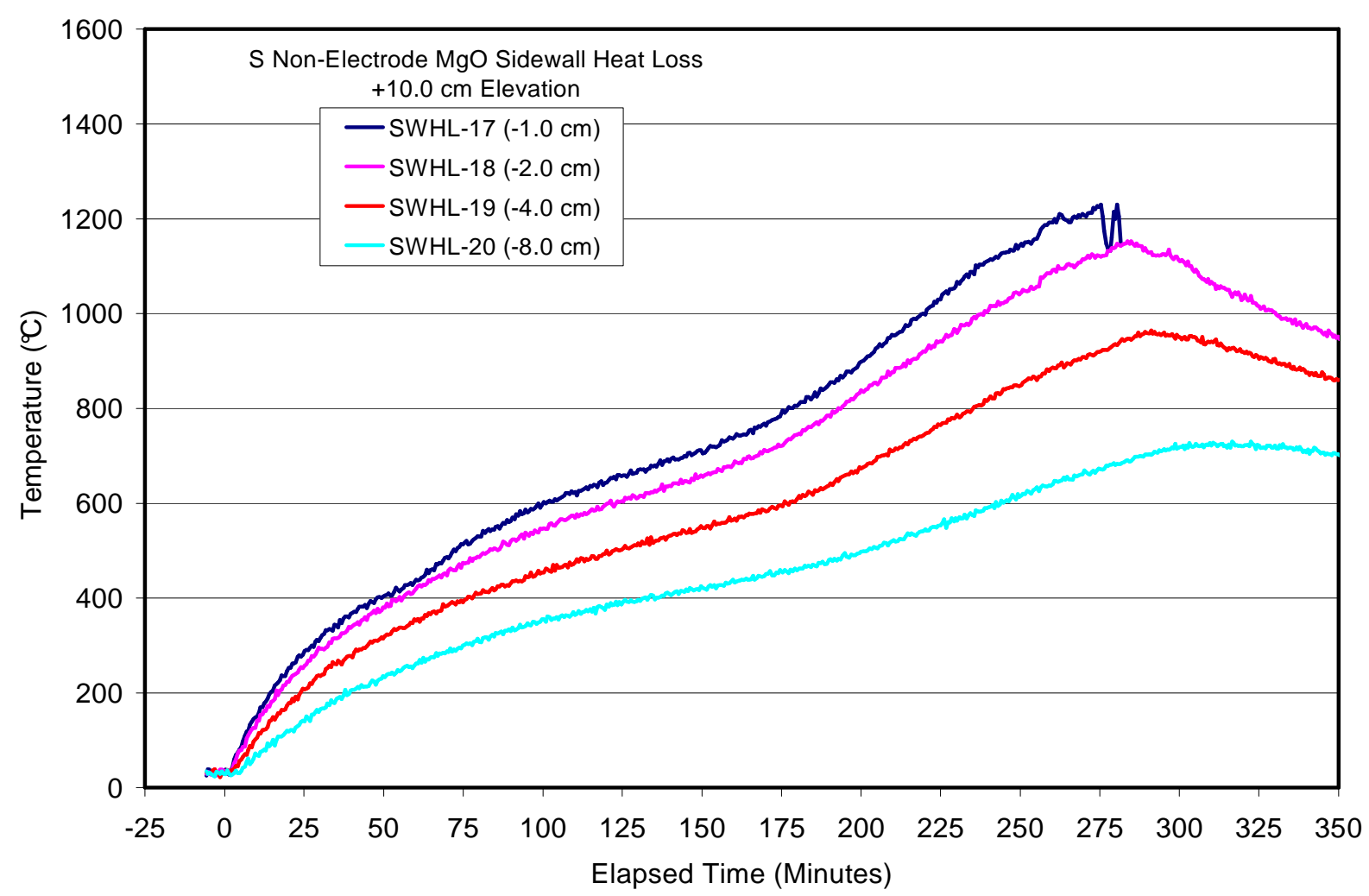

Figure 3-8. Thermal Response in South MgO Sidewall at the $+10 \mathrm{~cm}$ Elevation.

During the course of the interaction, the lid video camera provided some information on melt pool phenomenology. Over the first 49 minutes, the view of the melt surface was effectively blocked by aerosols generated from the core-concrete interaction. At $\sim 49$ minutes, aerosols in the plenum gradually cleared to reveal the interaction. The surface was observed to be crust free, and was highly agitated by sparging gases. The melt continued to heat up to the point where the view was lost due to high light intensity (through a No. 4 filter) at $\sim 54$ minutes. The view was effectively lost until $\sim 178$ minutes. At this time, the melt had cooled to the point where surface features could again be distinguished. This view revealed a predominately molten surface, with crust segments periodically forming on sidewalls, breaking off, and mixing back into the melt. From 259 to 271 minutes, the melt pyrometer measured a steady surface temperature decline from $1513{ }^{\circ} \mathrm{C}$ to $1250{ }^{\circ} \mathrm{C}$, before rebounding suddenly back to $1515{ }^{\circ} \mathrm{C}$. During this time interval crust material grew steadily out from the sidewalls to the point where the entire surface was covered, except for a small pocket in the northwest corner. At 269 minutes, melt began to flow over the crust. At 269.2 minutes, large crust segments gradually broke off and were mixed into the bulk, and by 269.5 minutes most of surface was crust-free. This re-sorption of crust material occurred simultaneously with the sudden increase in surface temperature from $1250{ }^{\circ} \mathrm{C}$ to $1515^{\circ} \mathrm{C}$ that was recorded by the optical pyrometer. 


\subsection{RESULTS}

A summary of key thermalhydraulic results from CCI-5 is provided in this section. A complete list of instruments used in the test is provided in Appendix A, while plots of all data logged from these instruments are provided in Appendix B.

\subsection{Electric Power}

The DEH power for CCI-5 is shown in Figure 4-1; the corresponding voltage and current traces are provided in Appendix B (see Figures B-50 and B-51, respectively). At completion of the thermite burn, the power supply voltage was steadily increased until the input power reached the target level of $145 \mathrm{~kW}$ at 1.9 minutes. Thereafter, input power was held constant at $\sim 145$ $\mathrm{kW}$ over the balance of dry cavity operations. A voltage tap change was made at 40.7 minutes in order to maintain constant power as the load resistance presented by the melt increased during the course of the test. Power input was terminated at 280.7 minutes on the basis of excessive heatup in the south $\mathrm{MgO}$ sidewall. Average input power over the time interval from 0 to 280.8 minutes was $143.8 \mathrm{~kW}$.

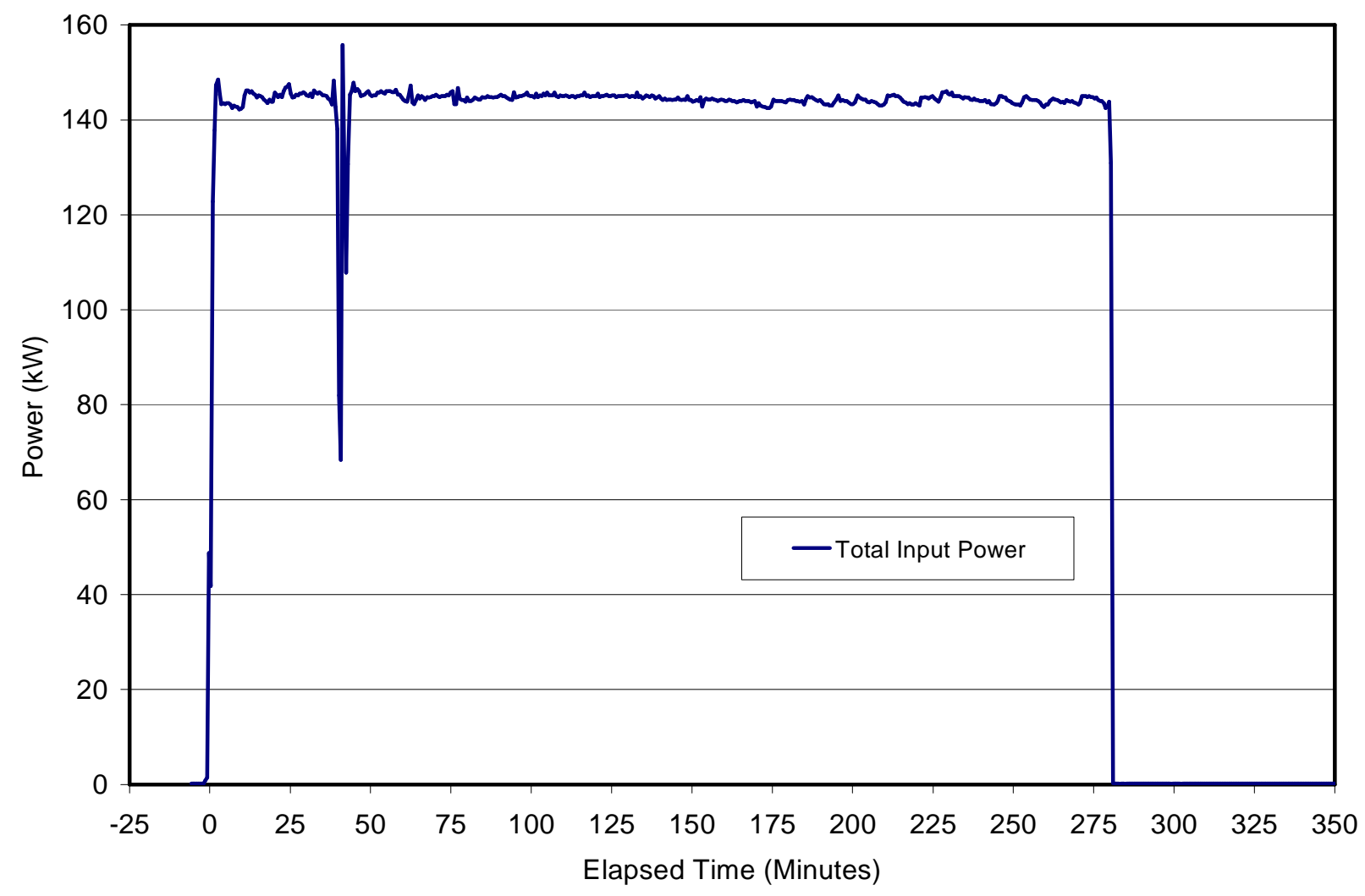

Figure 4-1. DEH Input Power.

\subsection{Melt Temperatures}

As described in Section 2.0, a total of twenty eight W5\%Re/W26\%Re (Type C) thermocouple junctions were used to monitor bulk melt temperatures at various axial and lateral locations in CCI-5. In addition, a two-color optical pyrometer was used to measure melt surface 
temperature. The data from all these instruments are shown collectively in Figure 4-2. To improve the readability, two actions have been taken: i) the data have been averaged or 30 second time intervals, and ii) only data preceding the first off-scale reading by the thermocouples are shown. Data plots for each individual instrument are provided in Appendix B.

Examination of Figure 4-2 indicates that the melt temperature declined from a high of $\sim 1950{ }^{\circ} \mathrm{C}$ measured soon after initial melt contact with the concrete surfaces, to $\sim 1630{ }^{\circ} \mathrm{C}$ at the time input power was terminated at 280 minutes. Over the last few hours of the interaction, melt temperatures were fairly uniform across the extent of the interaction, generally clustering within a band of approximately $\pm 50{ }^{\circ} \mathrm{C}$ of the average at any given time.

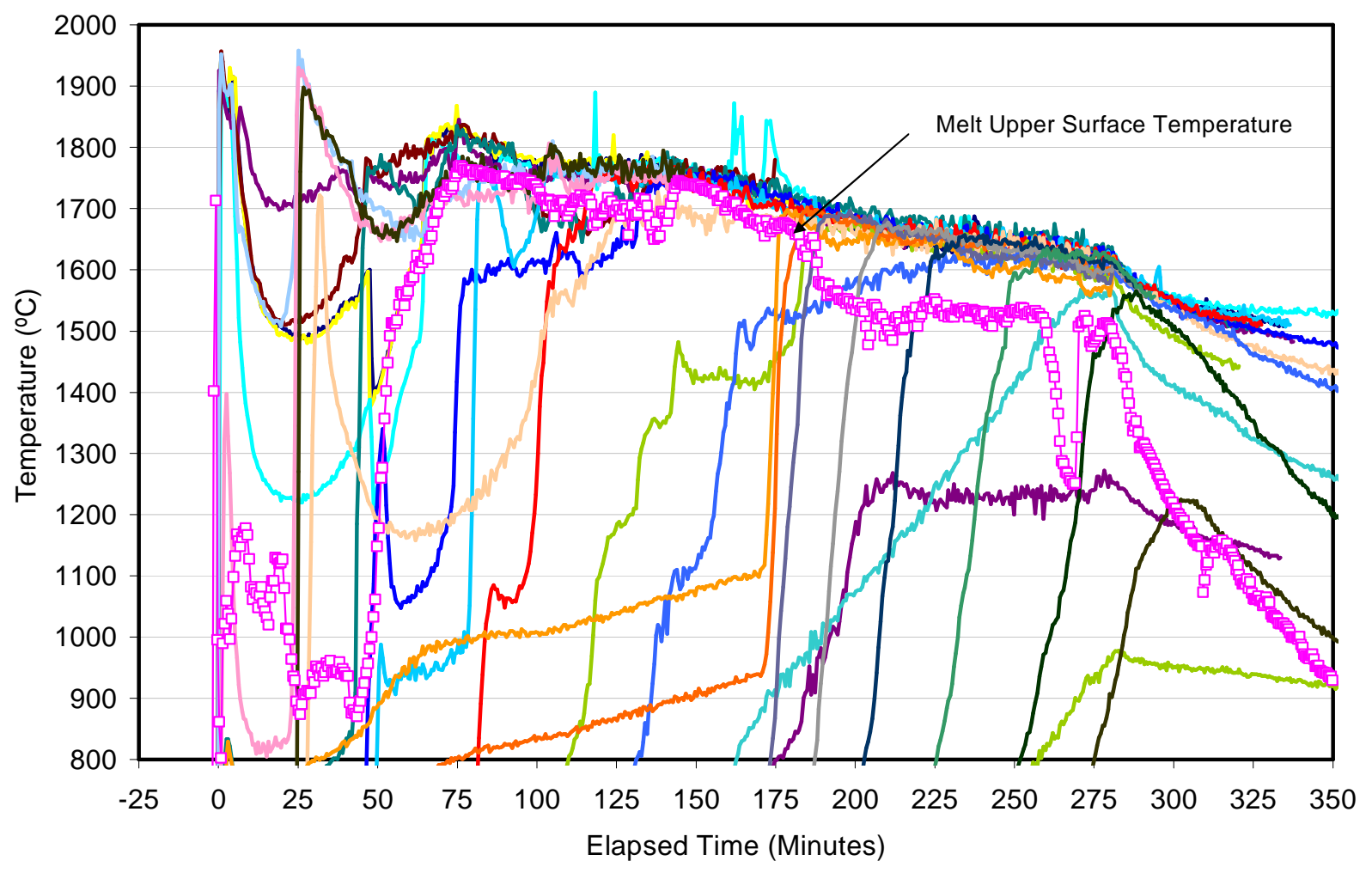

Figure 4-2. Melt Temperatures Measured During CCI-5.

\subsection{Concrete Basemat and Sidewall Ablation Rates}

As described in Section 2.0, the basemat was instrumented with five multi-junction Type $\mathrm{K}$ thermocouple arrays to monitor the axial progression of the ablation front, while the concrete sidewall was instrumented with fifteen arrays to monitor the lateral ablation front progression at eleven different elevations. When a thermocouple reached the siliceous concrete liquidus temperature of $1250{ }^{\circ} \mathrm{C}$ [5], the melt was considered to be in contact with the thermocouple at the junction location.

Figure 4-3 provides the axial ablation depth versus time based on the signal responses from the Type $\mathrm{K}$ basemat arrays, while Figure 4-4 provides the analogous plot of the lateral ablation depth in the North concrete wall. The ablation progression for test CCI-3, which was conducted with the same concrete type and at the same power level but with two ablating concrete sidewalls [6], is also shown in the figures for comparison. Examination of the data 
OECD/MCCI-2009-TR06 Rev. 1

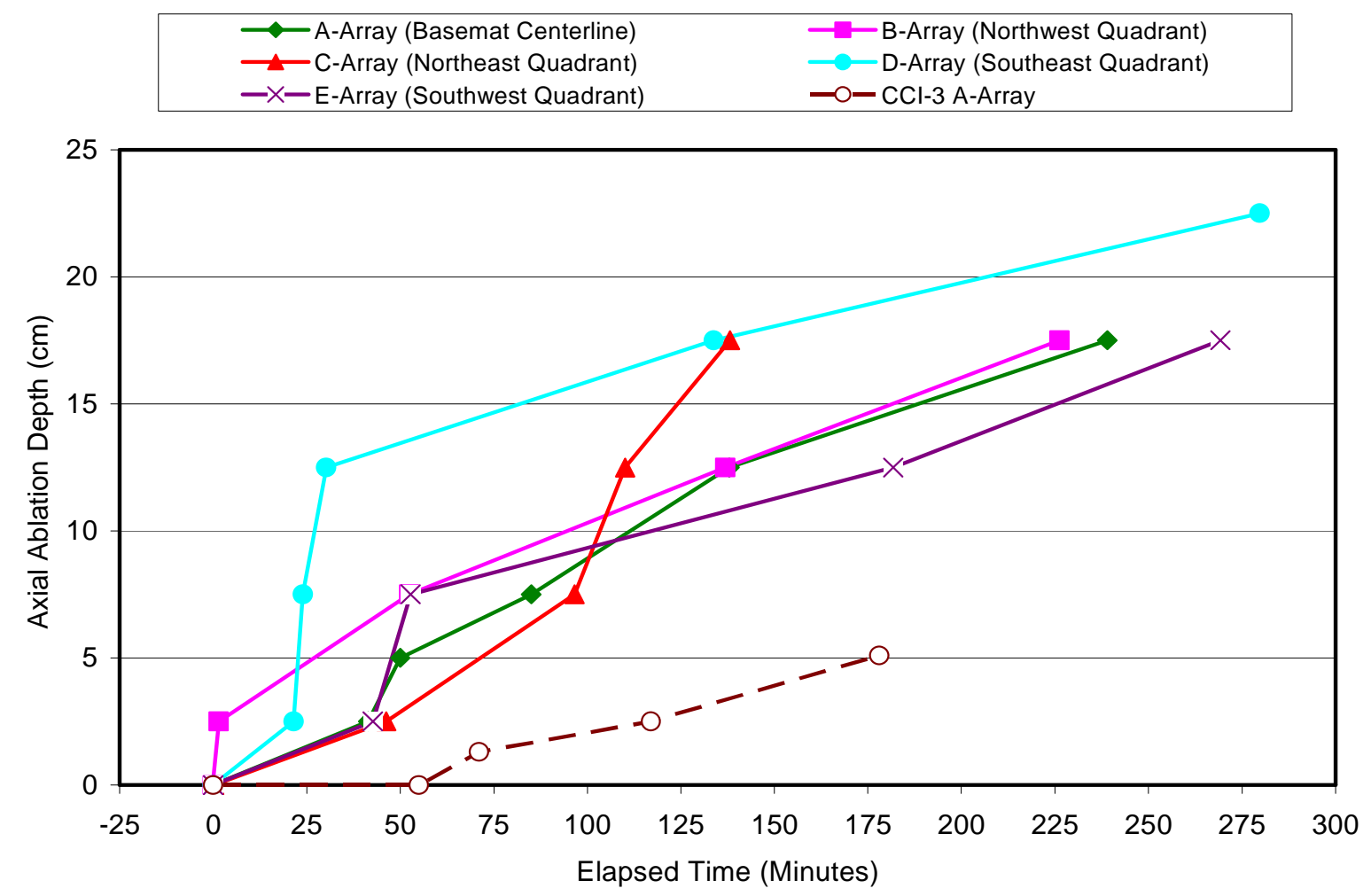

Figure 4-3. Basemat Axial Ablation Front Location.

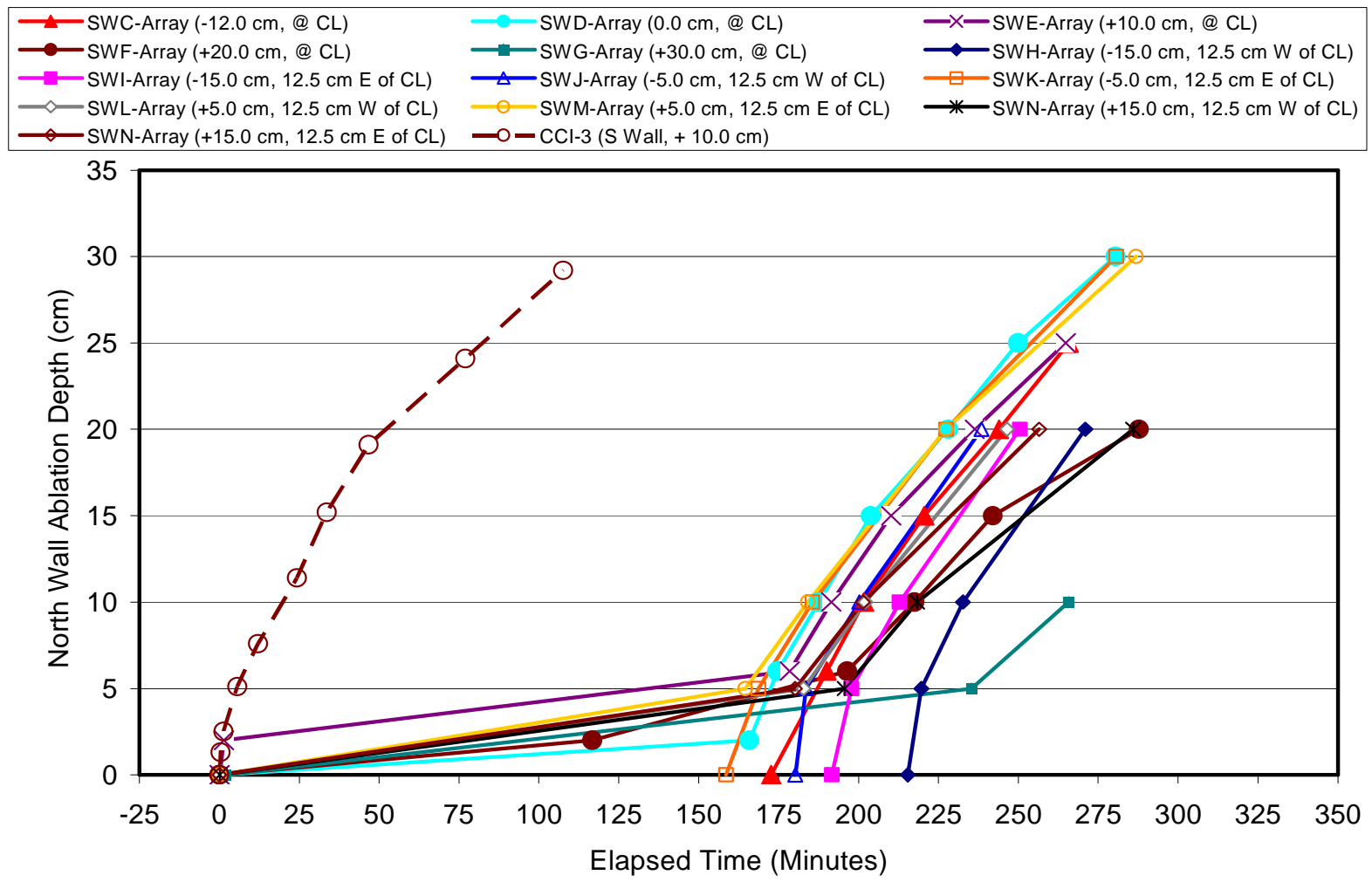

Figure 4-4. North Sidewall Lateral Ablation Front Location. 
indicates that axial erosion began almost immediately after contact with the basemat, and proceeded fairly steadily at a rate of $\sim 3 \mathrm{~cm} /$ hour after the initial transient had passed. Conversely, onset of significant sidewall ablation was delayed until $\sim 158$ minutes. At this time, lateral ablation proceeded in a uniform fashion at a rate of $\sim 10 \mathrm{~cm} /$ hour. At the time the test was terminated at 280 minutes, the peak axial ablation depth was $22.5 \mathrm{~cm}$, while the peak radial depth was $30 \mathrm{~cm}$. Additional information on the posttest cavity erosion profile is provided in the next subsection.

\subsection{Posttest Debris Examination and Chemical Analysis Results}

Following the test, the apparatus was carefully disassembled to document the posttest debris configuration. A picture showing a view into the cavity after removal of the test section lid is provided in Figure 4-5(a), while a view of the debris upper surface after removal of the middle section transition plate is provide in Figure 4-5(b). A side view of the lower section after removal of the $\mathrm{MgO}$ sidewalls is provided in Figure 4-6, while Figures 4-7 and 4-8 provide two different views of the solidified corium over the basemat after removal from the test section bottom plate. Figure 4-9 provides the analogous photographs of the corium remaining on the North concrete sidewall. Finally, renderings of the posttest debris configuration are provided in Figure 4-10. In general, the posttest examinations revealed that, in contrast to tests with limestone/common sand concrete, melt foaming was not a major issue and as a result the vast majority of the corium was left as a uniform layer atop the basemat. The morphology of the solidified corium for CCI-5 was somewhat different in comparison to the other CCI tests where the cavity was flooded late in the experiment sequence. In particular, for CCI-5, the solidified corium was dominated by a dense, monolithic, homogenous oxide layer over the basemat with very little porosity and few cracks. This morphology can be contrasted with the other tests in which there was generally a substantial layer of porous material $(5-10 \mathrm{~cm}$ thick) overlying monolithic material which had more cracks in comparison to the CCI-5 corium mass.

Consistent with the thermocouple measurements shown in Figures 4-3 through 4-4, the posttest examinations indicate that the overall cavity erosion was slightly skewed radially by the end of the experiment. As the debris was removed, samples were collected for chemical analysis by ICP/AES. Sample locations are shown in Figure 4-10. Key results from the analysis of five of these samples are provided in Table 4-1. The compositions shown in the table have been simplified in the terms of core, structural, and concrete $\left(\mathrm{CaO}, \mathrm{SiO}_{2}, \mathrm{MgO}, \mathrm{Al}_{2} \mathrm{O}_{3}\right)$ oxides; raw data are provided in Appendix C. Also provided in the table is an estimate of the end-of-test average melt composition that was formulated by taking the melt composition at the start of the test minus material splatter in the upper regions of the test section (50.44 kg; see Figure 4-10(a)), oxidizing all the remaining metals, and then incorporating $275.2 \mathrm{~kg}^{2}$ of slag from the decomposition of $321.1 \mathrm{~kg}$ of concrete that is estimated to have been eroded during the test.

Samples from the dense oxide layer (i.e., Nos. 5, 7, 8, and 9) do not indicate a significant dependency of the composition on axial or radial position within the layer. This observation is consistent with the melt temperature thermocouple measurements in the latter phase of the experiment that indicated that the melt pool was well mixed. The composition of the porous

\footnotetext{
${ }^{2}$ Slag mass estimated based on the eroded concrete mass of $321.1 \mathrm{~kg}$ after the loss of 14.28 wt $\%$ of $\mathrm{H}_{2} \mathrm{O}$ and $\mathrm{CO}_{2}$ gases upon decomposition; see initial concrete composition shown in Table 2-4.
} 
oxide layer on top the dense oxide was highly enriched in concrete oxides relative to the dense oxide. Overall, the samples contain slightly more concrete content than would be expected based on the estimated end of test composition. The discrepancy could arise thorough an underestimate of the mass of splatter material removed from the melt zone at the start of the experiment, which is possible since a substantial amount of material was deposited on the $\mathrm{MgO}$ sidewalls in the lower section (see Figure 3-33). However, segregating the initially deposited material from that subsequently deposited by melt voiding as the test progressed was not practical.

Table 4-1. Chemical Analysis Results for Samples Collected from CCI-5 Posttest Debris (data are in wt \%).

\begin{tabular}{|c|c|c|c|c|c|c|}
\hline Oxide & $\begin{array}{c}\mathbf{5} \\
\text { Dense Oxide } \\
\text { at Axial } \\
\text { Centerline } \\
\text { and by North } \\
\text { Wall }\end{array}$ & $\begin{array}{c}\mathbf{7} \\
\text { Dense Oxide } \\
\text { Near Core- } \\
\text { Concrete } \\
\text { Interface at } \\
\text { Center of Test } \\
\text { Section }\end{array}$ & $\begin{array}{c}\mathbf{8} \\
\text { Dense Oxide } \\
\text { Near Axial } \\
\text { Centerline at } \\
\text { Center of Test } \\
\text { Section }\end{array}$ & $\begin{array}{c}\mathbf{9} \\
\text { Dense Oxide } \\
\text { Near Top at } \\
\text { Center of } \\
\text { Test Section }\end{array}$ & $\begin{array}{c}\mathbf{1 0} \\
\text { Porous } \\
\text { Oxide at } \\
\text { Center of } \\
\text { Test } \\
\text { Section }\end{array}$ & $\begin{array}{c}\text { Estimated } \\
\text { End-of-Test } \\
\text { Composition }\end{array}$ \\
\hline $\mathrm{UO}_{2}$ & 34.04 & 33.71 & 33.39 & 31.16 & 25.67 & 36.59 \\
\hline $\mathrm{ZrO}_{2}$ & 12.27 & 10.14 & 12.32 & 12.53 & 12.70 & 15.02 \\
\hline $\mathrm{Cr}_{2} \mathrm{O}_{3}$ & 0.23 & 0.15 & 0.23 & 0.31 & 0.37 & 6.06 \\
\hline concrete & 53.46 & 56.00 & 54.07 & 55.99 & 61.25 & 42.33 \\
\hline Total & 100.00 & 100.00 & 100.00 & 100.00 & 100.00 & 100.00 \\
\hline
\end{tabular}




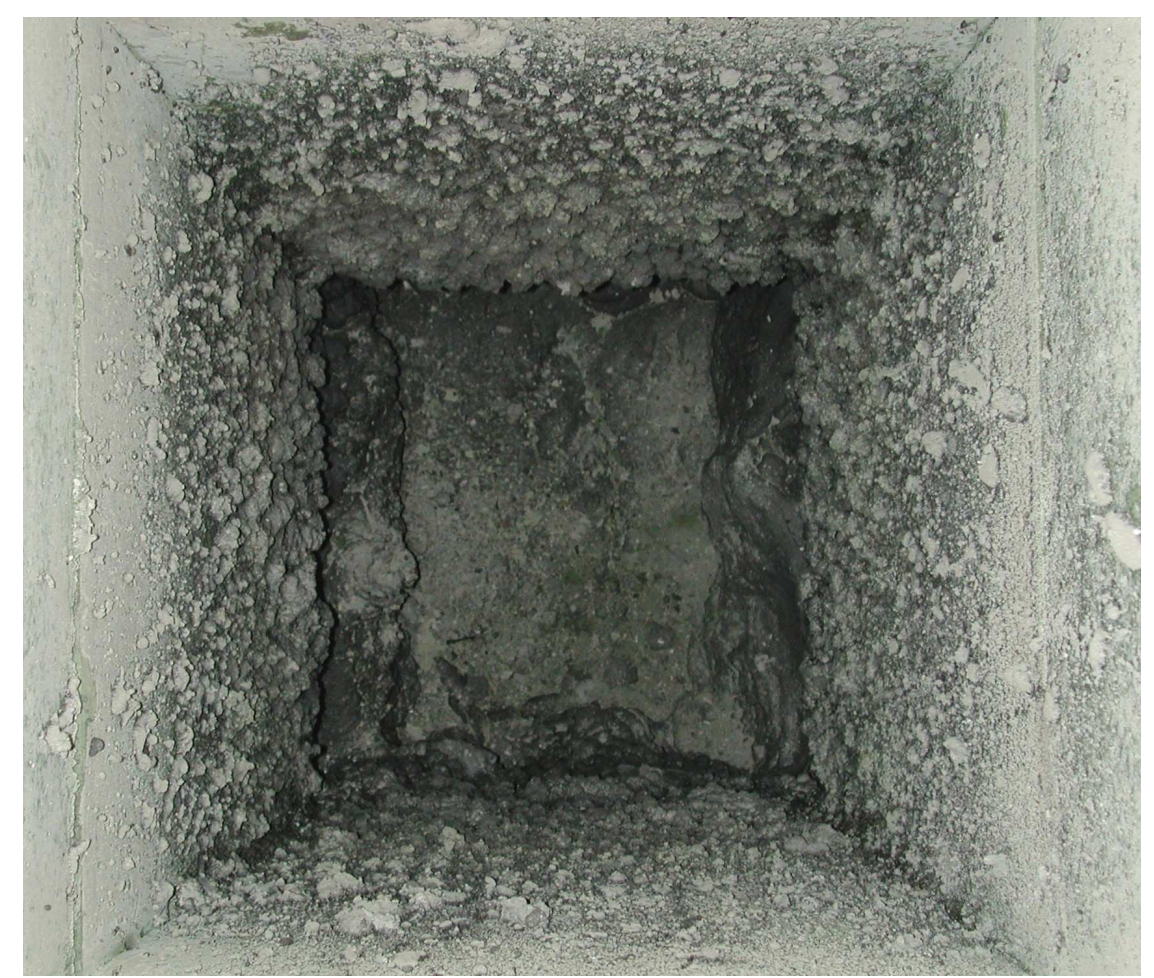

(a)

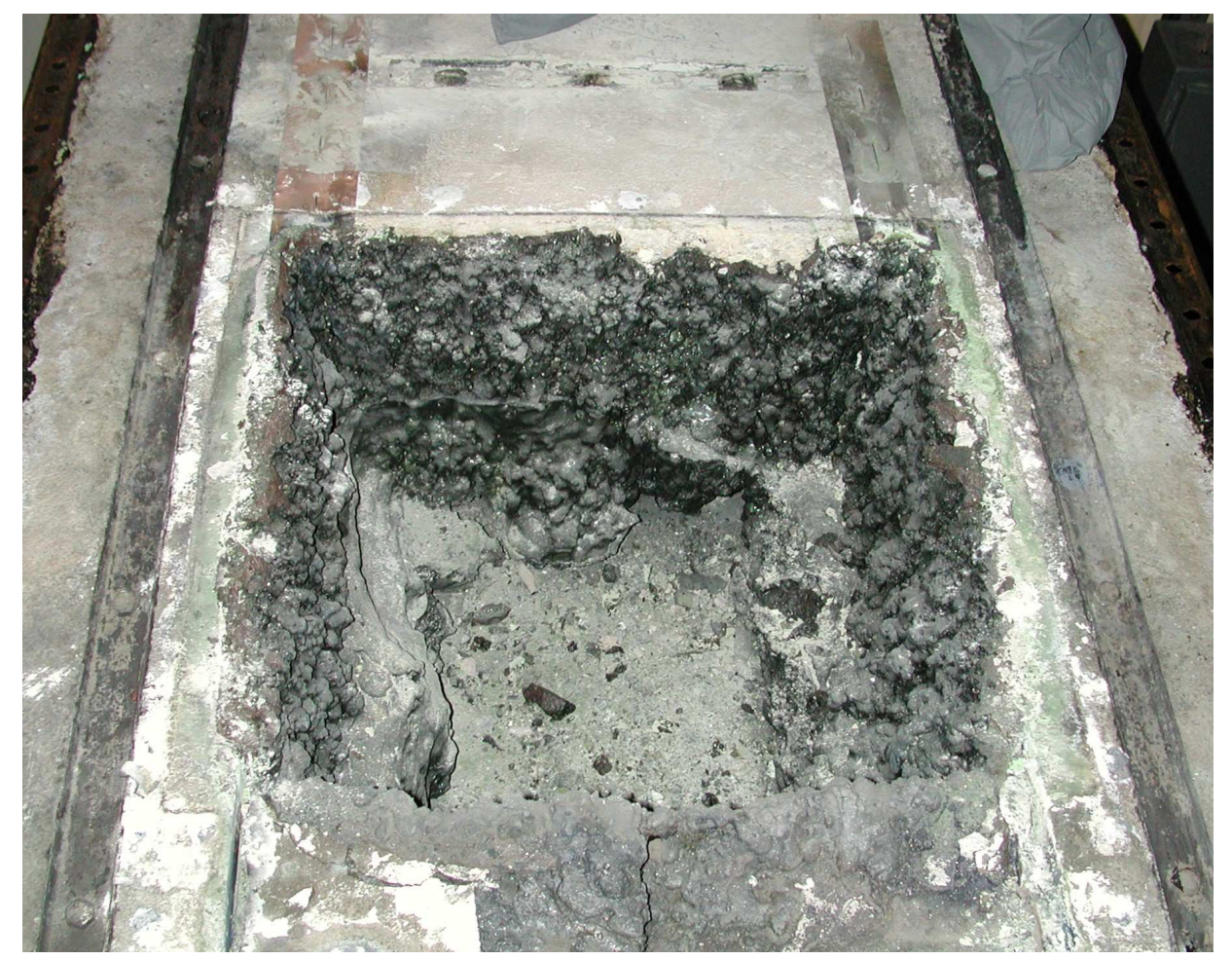

(b)

Figure 4-5. Top Views of the Test Section (a) After Lid Removal, and (b) After Removal of Top Section, Middle Section, and Test Section Transition Plate. 


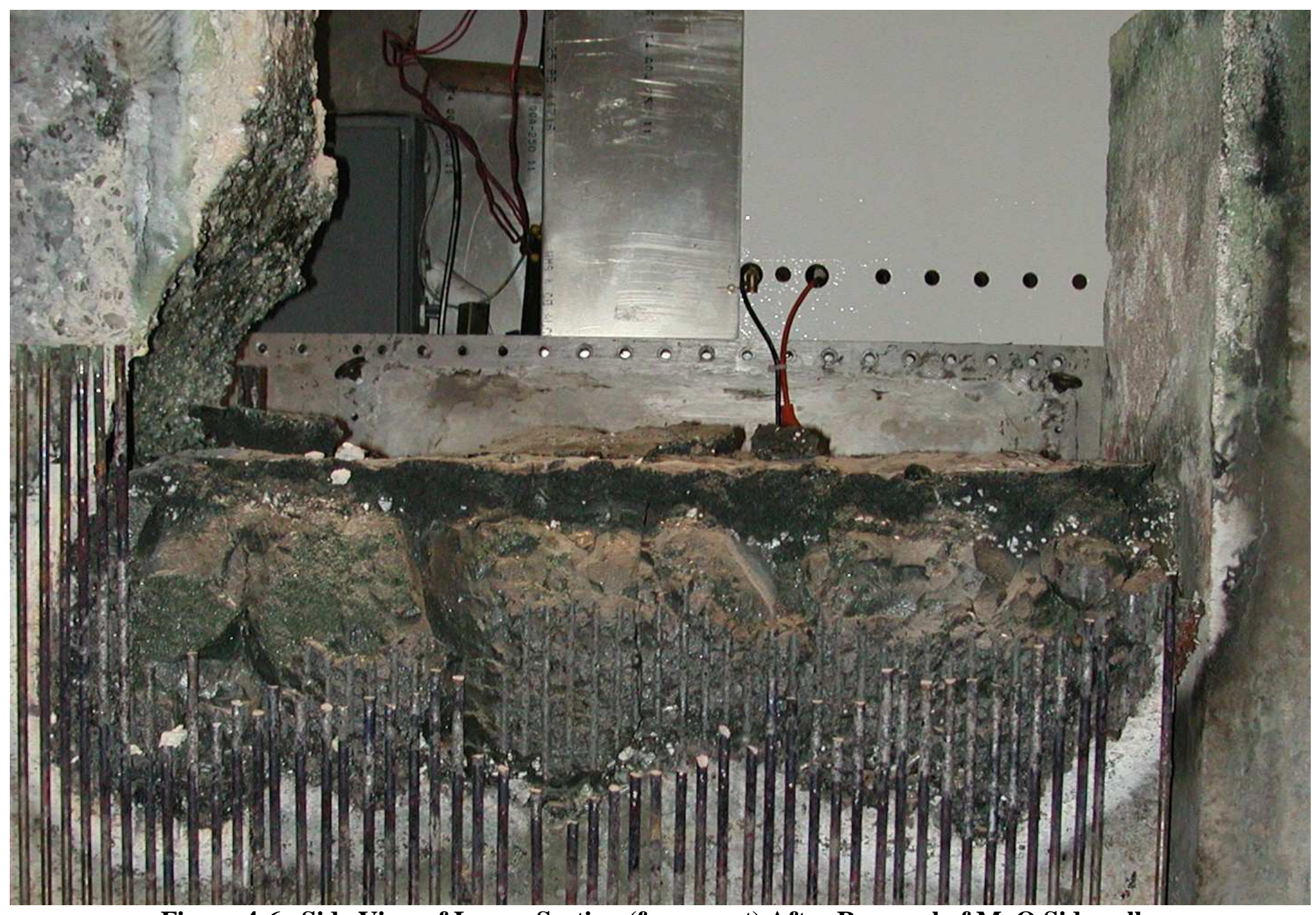

Figure 4-6. Side View of Lower Section (from west) After Removal of MgO Sidewalls. 


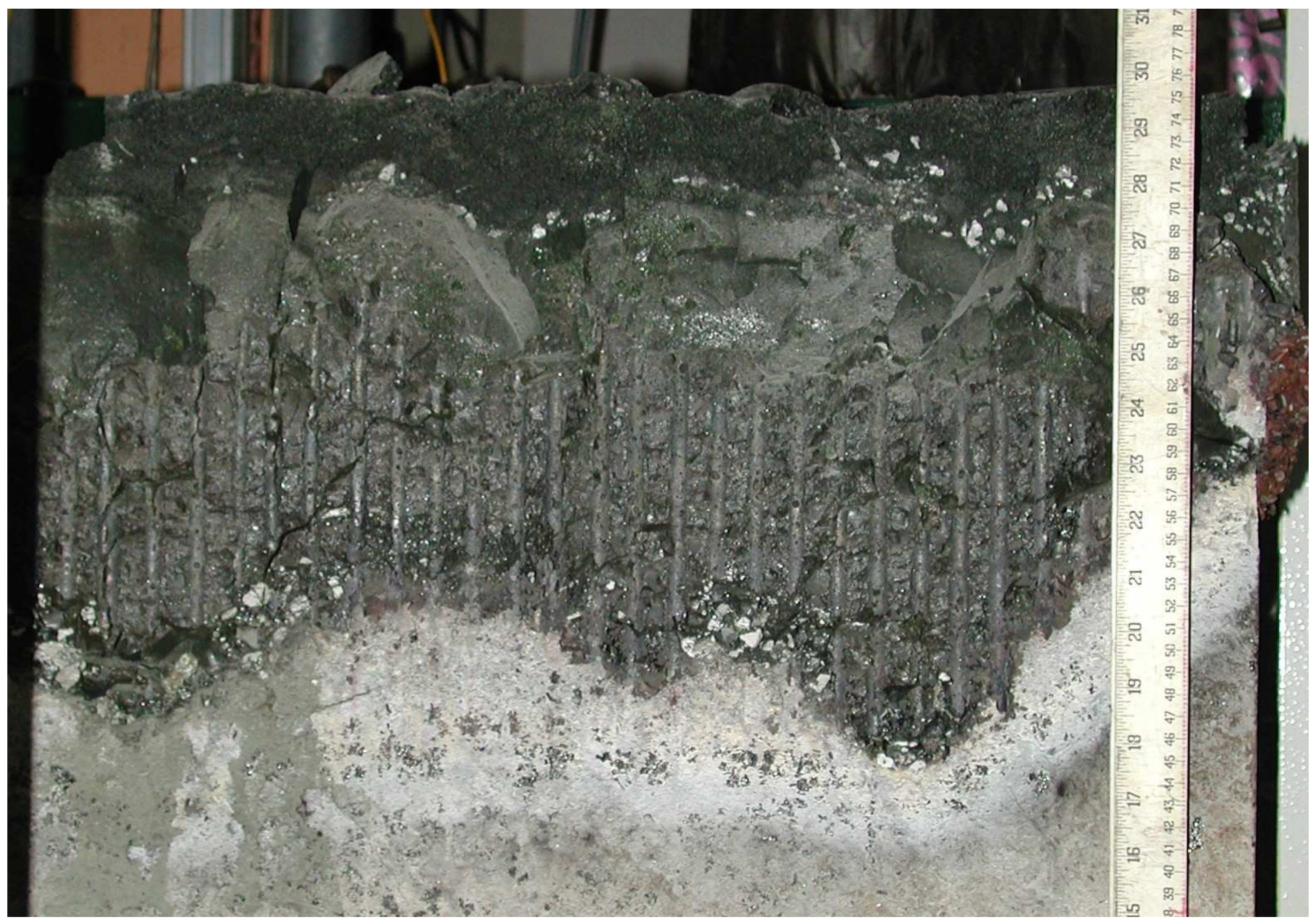

Figure 4-7. View from the West of the Solidified Corium over the Basemat. (The sintered $\mathrm{UO}_{2}$ pellets that protected the south MgO sidewall are visible on the far right of the photograph). 
OECD/MCCI-2009-TR06 Rev. 1

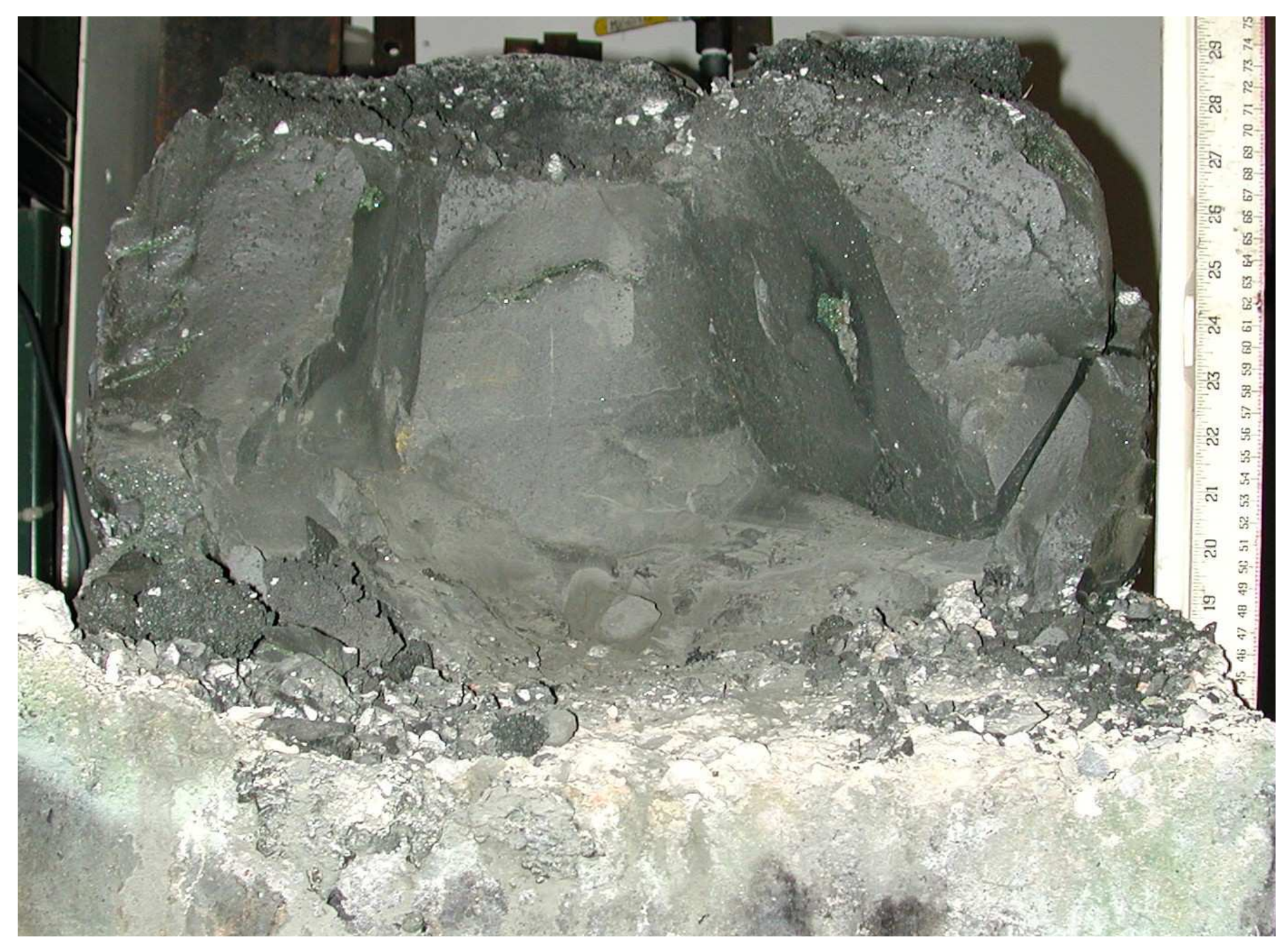

Figure 4-8. View from the North of the Solidified Corium over the Basemat. 
OECD/MCCI-2009-TR06 Rev. 1

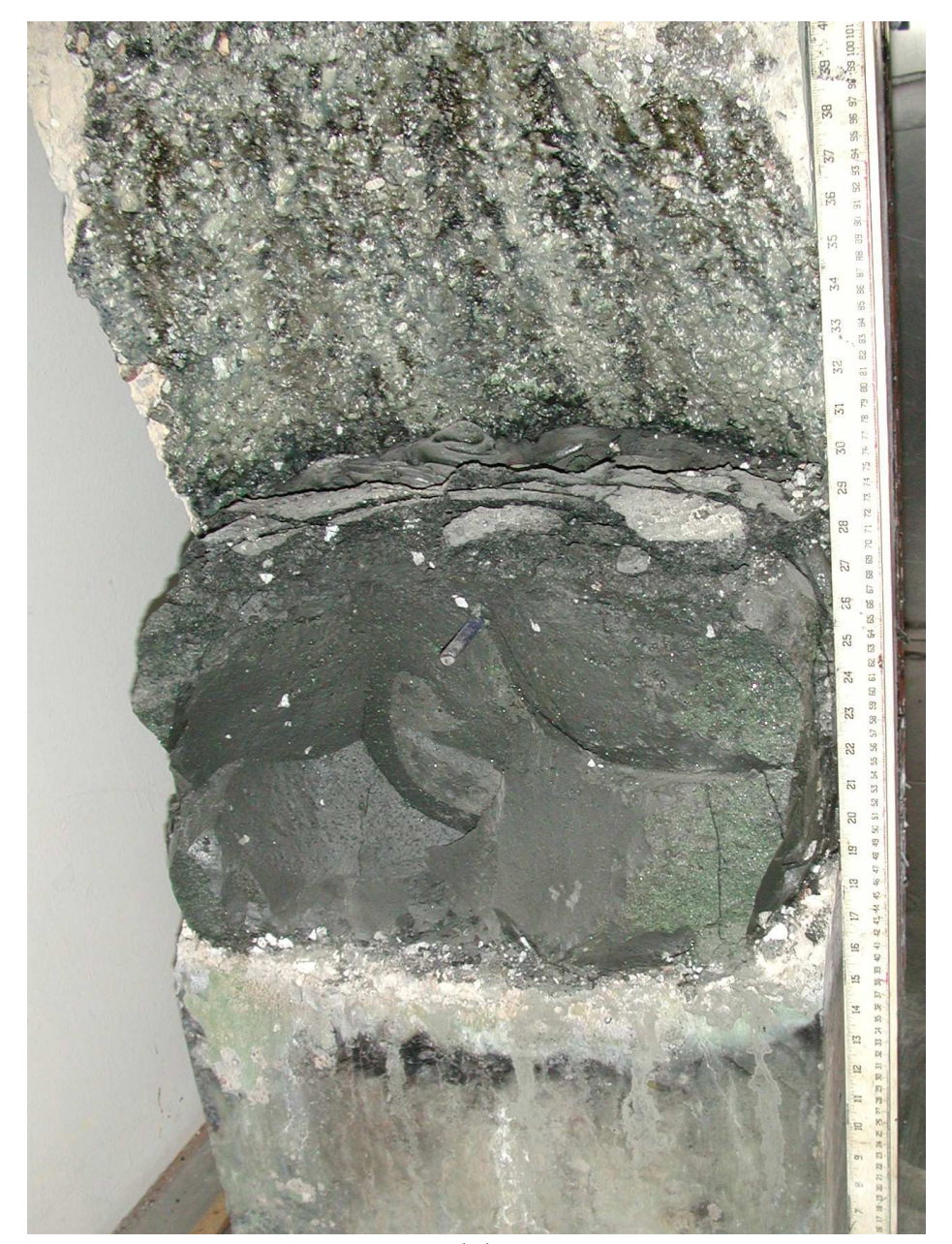

(a)

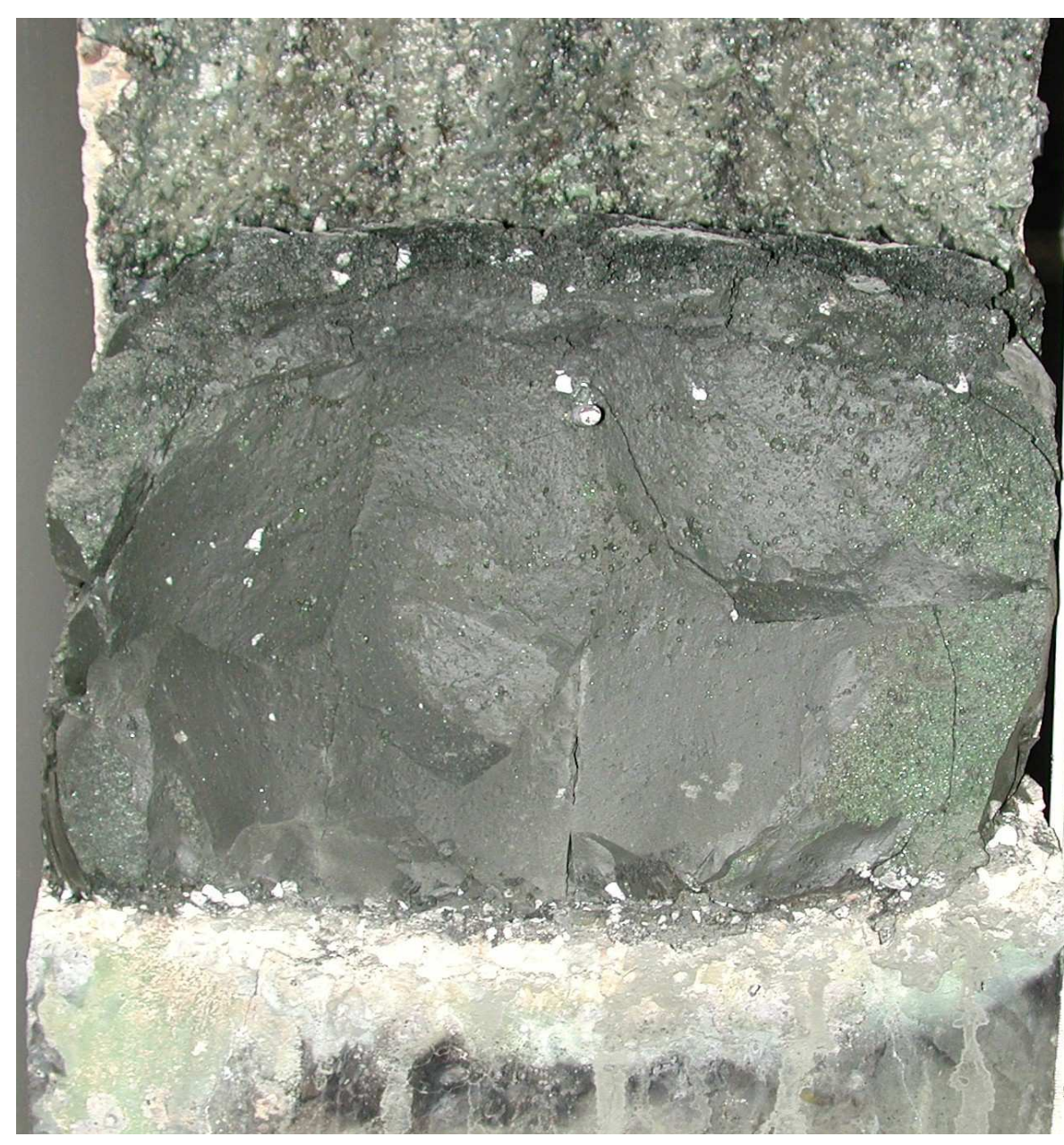

(b)

Figure 4-9. (a) Perspective and (b) Close-up Photographs of Corium on the North Concrete Sidewall. 


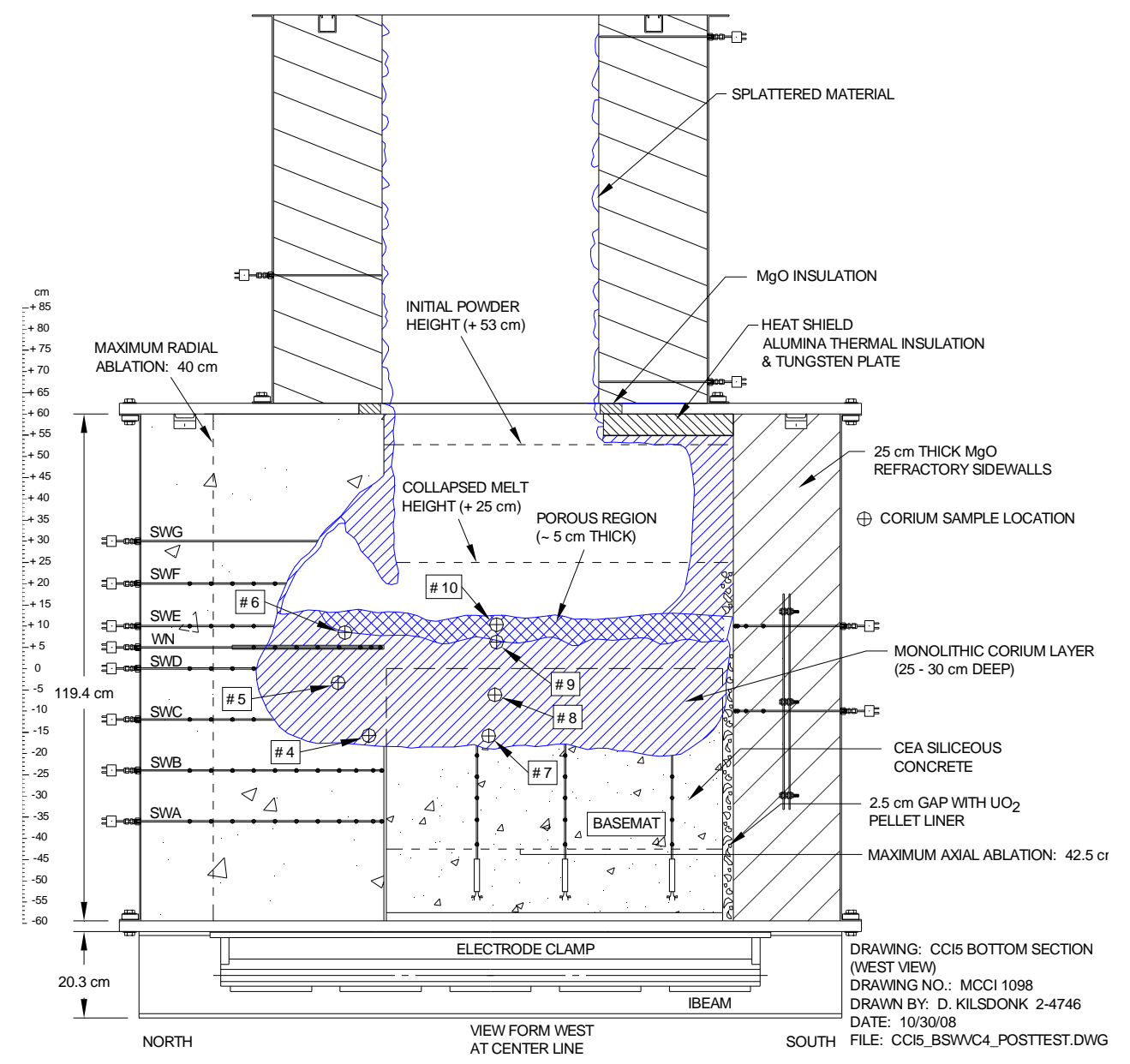

(a)

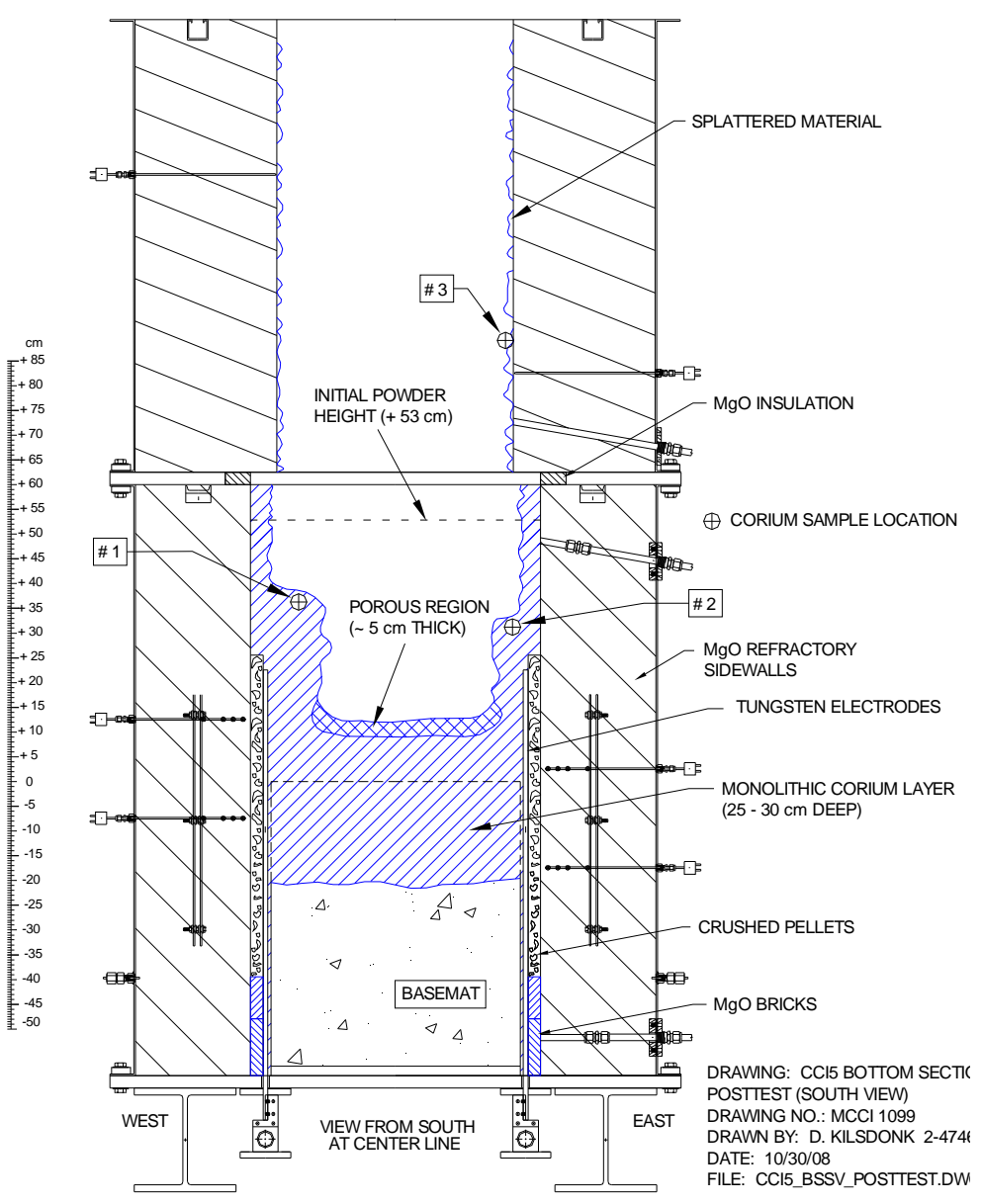

(b)

Figure 4-10. Posttest Debris Renderings as Viewed from the (a) West and (b) South. 
OECD/MCCI-2009-TR06 Rev. 1

\subsection{REFERENCES}

1. M. T. Farmer, S. Lomperski, D. J. Kilsdonk, and R. W. Aeschlimann, "OECD MCCI Project 2-D Core Concrete Interaction (CCI) Tests: Final Report," OECD/MCCI2005-TR05, January 2, 2006.

2. M. T. Farmer, R. W. Aeschlimann, D. J. Kilsdonk, and, S. Lomperski, "2-D Core Concrete Interaction (CCI) Tests CCI-4 Final Report," Rev.0, OECD/MCCI-2007TR06, November, 2007.

3. M. T. Farmer, D. J. Kilsdonk, S. Lomperski, and R. W. Aeschlimann, "Draft Specifications and Design for OECD/MCCI-2 Program CCI-5 Test," whitepaper, Rev. 0, October 26, 2007.

4. M. T. Farmer, D. J. Kilsdonk, S. Lomperski, and R. W. Aeschlimann, "Draft Specifications and Design for OECD/MCCI-2 Program CCI-5 Test," whitepaper, Rev. 1, November 20, 2007.

5. D. H. Thompson, M. T. Farmer, J. K. Fink, D. R. Armstrong, and B. W. Spencer, "ACE Phase C Final Report: Volume I-MCCI Thermalhydraulic Results," EPRI/ACETR-C42, September, 1997.

6. M. T. Farmer, S. Lomperski, D. J. Kilsdonk, R. W. Aeschlimann, and S. Basu, "2-D Core Concrete Interaction (CCI) Tests: CCI-3 Test Data Report-Thermalhydraulic Results,” Rev. 0, OECD/MCCI-2005-TR04, October 15, 2005 


\section{APPENDIX A \\ Data Acquisition System Channel Assignments}

This Appendix provides the channel assignments for the three independent DAS systems that were used to record the data for CCI-5. For convenience, these three 128 channel systems were referred to the "Basemat", "Power," and "Quench" systems by operating personnel. The channel assignment lists for each of these three systems are provided in Tables A-1 through A-3. The data recorded on each of these channels is provided in Appendix B. 
OECD/MCCI-2009-TR06 Rev. 1

Table A-1. "Concrete" DAS Channel Assignments for CCI-5.

\begin{tabular}{|c|c|c|c|c|c|c|}
\hline Channel & Variable & Sensor & Location & Elevation & Range/Limit & Accuracy \\
\hline 00 & $\mathrm{~T}$ & Diode Sensor & TC compensation Channels B01-B49 & & $130 \mathrm{C}$ & \\
\hline 01 & $\mathrm{~T}$ & TC Type C & Concrete Basemat $0.0 \mathrm{~cm},+1.9 \mathrm{~cm}$ WCL-1 & $+15.0 \mathrm{~cm}$ & $2320 \mathrm{C}$ & $\pm 1 \%$ \\
\hline 02 & $\mathrm{~T}$ & TC Type C & Concrete Basemat $0.0 \mathrm{~cm},+1.9 \mathrm{~cm}$ WCL-2 & $+10.0 \mathrm{~cm}$ & $2320 \mathrm{C}$ & $\pm 1 \%$ \\
\hline 03 & $\mathrm{~T}$ & TC Type C & Concrete Basemat $0.0 \mathrm{~cm},+1.9 \mathrm{~cm}$ WCL-3 & $+5.0 \mathrm{~cm}$ & $2320 \mathrm{C}$ & $\pm 1 \%$ \\
\hline 04 & $\mathrm{~T}$ & TC Type $\mathrm{C}$ & Concrete Basemat $0.0 \mathrm{~cm},+1.9 \mathrm{~cm}$ WCL-4 & $0.0 \mathrm{~cm}$ & $2320 \mathrm{C}$ & $\pm 1 \%$ \\
\hline 05 & $\mathrm{~T}$ & TC Type C & Concrete Basemat $-11.2 \mathrm{~cm},+17.5 \mathrm{~cm} \mathrm{WNW-1}$ & $+9.0 \mathrm{~cm}$ & $2320 \mathrm{C}$ & $\pm 1 \%$ \\
\hline 06 & $\mathrm{~T}$ & TC Type C & Concrete Basemat $-11.2 \mathrm{~cm},+17.5 \mathrm{~cm} \mathrm{WNW-2}$ & $+4.0 \mathrm{~cm}$ & $2320 \mathrm{C}$ & $\pm 1 \%$ \\
\hline 07 & $\mathrm{~T}$ & TC Type C & Concrete Basemat $-11.2 \mathrm{~cm},+17.5 \mathrm{~cm}$ WNW-3 & $-1.0 \mathrm{~cm}$ & $2320 \mathrm{C}$ & $\pm 1 \%$ \\
\hline 08 & $\mathrm{~T}$ & TC Type C & Concrete Basemat $-11.2 \mathrm{~cm},+17.5 \mathrm{~cm} \mathrm{WNW-4}$ & $-6.0 \mathrm{~cm}$ & $2320 \mathrm{C}$ & $\pm 1 \%$ \\
\hline 09 & $\mathrm{~T}$ & TC Type C & Concrete Basemat $+11.2 \mathrm{~cm},+17.5 \mathrm{~cm} \mathrm{WNE}-1$ & $-3.0 \mathrm{~cm}$ & $2320 \mathrm{C}$ & $\pm 1 \%$ \\
\hline 10 & $\mathrm{~T}$ & TC Type C & Concrete Basemat $+11.2 \mathrm{~cm},+17.5 \mathrm{~cm} \mathrm{WNE}-2$ & $-8.0 \mathrm{~cm}$ & $2320 \mathrm{C}$ & $\pm 1 \%$ \\
\hline 11 & $\mathrm{~T}$ & TC Type C & Concrete Basemat $+11.2 \mathrm{~cm},+17.5 \mathrm{~cm} \mathrm{WNE}-3$ & $-13.0 \mathrm{~cm}$ & $2320 \mathrm{C}$ & $\pm 1 \%$ \\
\hline 12 & $\mathrm{~T}$ & TC Type C & Concrete Basemat $+11.2 \mathrm{~cm},+17.5 \mathrm{~cm} \mathrm{WNE}-4$ & $-18.0 \mathrm{~cm}$ & $2320 \mathrm{C}$ & $\pm 1 \%$ \\
\hline 13 & $\mathrm{~T}$ & TC Type C & Concrete Basemat $+11.2 \mathrm{~cm},-17.5 \mathrm{~cm}$ WSE- 1 & $+3.0 \mathrm{~cm}$ & $2320 \mathrm{C}$ & $\pm 1 \%$ \\
\hline 14 & $\mathrm{~T}$ & TC Type C & Concrete Basemat $+11.2 \mathrm{~cm},-17.5 \mathrm{~cm}$ WSE-2 & $-2.0 \mathrm{~cm}$ & $2320 \mathrm{C}$ & $\pm 1 \%$ \\
\hline 15 & $\mathrm{~T}$ & TC Type C & Concrete Basemat $+11.2 \mathrm{~cm},-17.5 \mathrm{~cm} \mathrm{WSE}-3$ & $-7.0 \mathrm{~cm}$ & $2320 \mathrm{C}$ & $\pm 1 \%$ \\
\hline 16 & $\mathrm{~T}$ & TC Type C & Concrete Basemat $+11.2 \mathrm{~cm},-17.5 \mathrm{~cm}$ WSE-4 & $-12.0 \mathrm{~cm}$ & $2320 \mathrm{C}$ & $\pm 1 \%$ \\
\hline 17 & $\mathrm{~T}$ & TC Type C & Concrete Basemat $-11.2 \mathrm{~cm},-17.5 \mathrm{~cm}$ WSW-1 & $-9.0 \mathrm{~cm}$ & $2320 \mathrm{C}$ & $\pm 1 \%$ \\
\hline 18 & $\mathrm{~T}$ & TC Type C & Concrete Basemat $-11.2 \mathrm{~cm},-17.5 \mathrm{~cm}$ WSW-2 & $-14.0 \mathrm{~cm}$ & $2320 \mathrm{C}$ & $\pm 1 \%$ \\
\hline 19 & $\mathrm{~T}$ & TC Type C & Concrete Basemat $-11.2 \mathrm{~cm},-17.5 \mathrm{~cm}$ WSW-3 & $-19.0 \mathrm{~cm}$ & $2320 \mathrm{C}$ & $\pm 1 \%$ \\
\hline 20 & $\mathrm{~T}$ & TC Type C & Concrete Basemat $-11.2 \mathrm{~cm},-17.5 \mathrm{~cm} \mathrm{WSW}-4$ & $-24.0 \mathrm{~cm}$ & $2320 \mathrm{C}$ & $\pm 1 \%$ \\
\hline 21 & $\mathrm{~T}$ & TC Type $\mathrm{C}$ & N Concrete Sidewall, $0.0 \mathrm{~cm}$ deep, centerline WN-1 & $+5.0 \mathrm{~cm}$ & $2320 \mathrm{C}$ & $\pm 1 \%$ \\
\hline 22 & $\mathrm{~T}$ & TC Type C & N Concrete Sidewall, $2.5 \mathrm{~cm}$ deep, centerline WN-2 & $+5.0 \mathrm{~cm}$ & $2320 \mathrm{C}$ & $\pm 1 \%$ \\
\hline 23 & $\mathrm{~T}$ & TC Type C & N Concrete Sidewall, $5.0 \mathrm{~cm}$ deep, centerline WN-3 & $+5.0 \mathrm{~cm}$ & $2320 \mathrm{C}$ & $\pm 1 \%$ \\
\hline 24 & $\mathrm{~T}$ & TC Type C & N Concrete Sidewall, $10.0 \mathrm{~cm}$ deep, centerline WN-4 & $+5.0 \mathrm{~cm}$ & $2320 \mathrm{C}$ & $\pm 1 \%$ \\
\hline 25 & $\mathrm{~T}$ & TC Type K & N Concrete Sidewall, $35.0 \mathrm{~cm}$ deep, centerline SWA-9 & $-36.0 \mathrm{~cm}$ & $1400 \mathrm{C}$ & $\pm 0.75 \%$ \\
\hline 26 & $\mathrm{~T}$ & TC Type K & N Concrete Sidewall $40.0 \mathrm{~cm}$ deep, centerline SWA-10 & $-36.0 \mathrm{~cm}$ & $1400 \mathrm{C}$ & $\pm 0.75 \%$ \\
\hline
\end{tabular}


OECD/MCCI-2009-TR06 Rev. 1

\begin{tabular}{|c|c|c|c|c|c|c|}
\hline 27 & $\mathrm{~T}$ & TC Type K & N Concrete Sidewall $45.0 \mathrm{~cm}$ deep, centerline SWA-11 & $-36.0 \mathrm{~cm}$ & $1400 \mathrm{C}$ & $\pm 0.75 \%$ \\
\hline 28 & $\mathrm{~T}$ & TC Type C & N Concrete Sidewall, $15.0 \mathrm{~cm}$ deep, centerline WN-5 & $+5.0 \mathrm{~cm}$ & $2320 \mathrm{C}$ & $\pm 1 \%$ \\
\hline 29 & $\mathrm{~T}$ & TC Type K & Concrete Basemat $0.0 \mathrm{~cm},-1.9 \mathrm{~cm} \mathrm{A-1}$ & $0.0 \mathrm{~cm}$ & $1400 \mathrm{C}$ & $\pm 0.75 \%$ \\
\hline 30 & $\mathrm{~T}$ & TC Type K & Concrete Basemat $0.0 \mathrm{~cm},-1.9 \mathrm{~cm} \mathrm{A-2}$ & $-2.5 \mathrm{~cm}$ & $1400 \mathrm{C}$ & $\pm 0.75 \%$ \\
\hline 31 & $\mathrm{~T}$ & TC Type K & Concrete Basemat $0.0 \mathrm{~cm},-1.9 \mathrm{~cm} \mathrm{A-3}$ & $-5.0 \mathrm{~cm}$ & $1400 \mathrm{C}$ & $\pm 0.75 \%$ \\
\hline 32 & $\mathrm{~T}$ & TC Type K & Concrete Basemat $0.0 \mathrm{~cm},-1.9 \mathrm{~cm} \mathrm{~A}-4$ & $-7.5 \mathrm{~cm}$ & $1400 \mathrm{C}$ & $\pm 0.75 \%$ \\
\hline 33 & $\mathrm{~T}$ & TC Type K & Concrete Basemat $0.0 \mathrm{~cm},-1.9 \mathrm{~cm} \mathrm{A-5}$ & $-12.5 \mathrm{~cm}$ & $1400 \mathrm{C}$ & $\pm 0.75 \%$ \\
\hline 34 & $\mathrm{~T}$ & TC Type K & Concrete Basemat $0.0 \mathrm{~cm},-1.9 \mathrm{~cm} \mathrm{A-6}$ & $-17.5 \mathrm{~cm}$ & $1400 \mathrm{C}$ & $\pm 0.75 \%$ \\
\hline 35 & $\mathrm{~T}$ & TC Type K & Concrete Basemat $0.0 \mathrm{~cm},-1.9 \mathrm{~cm} \mathrm{~A}-7$ & $-22.5 \mathrm{~cm}$ & $1400 \mathrm{C}$ & $\pm 0.75 \%$ \\
\hline 36 & $\mathrm{~T}$ & TC Type K & Concrete Basemat $0.0 \mathrm{~cm},-1.9 \mathrm{~cm} \mathrm{A-} 8$ & $-27.5 \mathrm{~cm}$ & $1400 \mathrm{C}$ & $\pm 0.75 \%$ \\
\hline 37 & $\mathrm{~T}$ & TC Type K & Concrete Basemat $0.0 \mathrm{~cm},-1.9 \mathrm{~cm} \mathrm{A-9}$ & $-32.5 \mathrm{~cm}$ & $1400 \mathrm{C}$ & $\pm 0.75 \%$ \\
\hline 38 & $\mathrm{~T}$ & TC Type K & Concrete Basemat $0.0 \mathrm{~cm},-1.9 \mathrm{~cm} \mathrm{A-10}$ & $-37.5 \mathrm{~cm}$ & $1400 \mathrm{C}$ & $\pm 0.75 \%$ \\
\hline 39 & $\mathrm{~T}$ & TC Type K & Concrete Basemat $0.0 \mathrm{~cm},-1.9 \mathrm{~cm} \mathrm{A-11}$ & $-42.5 \mathrm{~cm}$ & $1400 \mathrm{C}$ & $\pm 0.75 \%$ \\
\hline 40 & $\mathrm{~T}$ & TC Type K & Concrete Basemat $-12.5 \mathrm{~cm},+19.7 \mathrm{~cm} \mathrm{~B}-1$ & $0.0 \mathrm{~cm}$ & $1400 \mathrm{C}$ & $\pm 0.75 \%$ \\
\hline 41 & $\mathrm{~T}$ & TC Type K & Concrete Basemat $-12.5 \mathrm{~cm},+19.7 \mathrm{~cm} \mathrm{B-2}$ & $-2.5 \mathrm{~cm}$ & $1400 \mathrm{C}$ & $\pm 0.75 \%$ \\
\hline 42 & $\mathrm{~T}$ & TC Type K & Concrete Basemat $-12.5 \mathrm{~cm},+19.7 \mathrm{~cm} \mathrm{~B}-3$ & $-7.5 \mathrm{~cm}$ & $1400 \mathrm{C}$ & $\pm 0.75 \%$ \\
\hline 43 & $\mathrm{~T}$ & TC Type K & Concrete Basemat $-12.5 \mathrm{~cm},+19.7 \mathrm{~cm} \mathrm{~B}-4$ & $-12.5 \mathrm{~cm}$ & $1400 \mathrm{C}$ & $\pm 0.75 \%$ \\
\hline 44 & $\mathrm{~T}$ & TC Type K & Concrete Basemat $-12.5 \mathrm{~cm},+19.7 \mathrm{~cm} \mathrm{~B}-5$ & $-17.5 \mathrm{~cm}$ & $1400 \mathrm{C}$ & $\pm 0.75 \%$ \\
\hline 45 & $\mathrm{~T}$ & TC Type K & Concrete Basemat $-12.5 \mathrm{~cm},+19.7 \mathrm{~cm} \mathrm{~B}-6$ & $-22.5 \mathrm{~cm}$ & $1400 \mathrm{C}$ & $\pm 0.75 \%$ \\
\hline 46 & $\mathrm{~T}$ & TC Type K & Concrete Basemat $-12.5 \mathrm{~cm},+19.7 \mathrm{~cm} \mathrm{~B}-7$ & $-27.5 \mathrm{~cm}$ & $1400 \mathrm{C}$ & $\pm 0.75 \%$ \\
\hline 47 & $\mathrm{~T}$ & TC Type K & Concrete Basemat $-12.5 \mathrm{~cm},+19.7 \mathrm{~cm} \mathrm{~B}-8$ & $-35.0 \mathrm{~cm}$ & $1400 \mathrm{C}$ & $\pm 0.75 \%$ \\
\hline 48 & $\mathrm{~T}$ & TC Type K & Concrete Basemat $-12.5 \mathrm{~cm},+19.7 \mathrm{~cm} \mathrm{B-9}$ & $-42.5 \mathrm{~cm}$ & $1400 \mathrm{C}$ & $\pm 0.75 \%$ \\
\hline 49 & $\mathrm{~T}$ & TC Type C & N Concrete Sidewall, $20.0 \mathrm{~cm}$ deep, centerline WN-6 & $+5.0 \mathrm{~cm}$ & $2320 \mathrm{C}$ & $\pm 1 \%$ \\
\hline 50 & $\mathrm{~T}$ & Diode Sensor & TC compensation Channels B51-B99 & & $130 \mathrm{C}$ & \\
\hline 51 & $\mathrm{~T}$ & TC Type K & Concrete Basemat $+12.5 \mathrm{~cm},+19.7 \mathrm{~cm} \mathrm{C}-1$ & $0.0 \mathrm{~cm}$ & $1400 \mathrm{C}$ & $\pm 0.75 \%$ \\
\hline 52 & $\mathrm{~T}$ & TC Type K & Concrete Basemat $+12.5 \mathrm{~cm},+19.7 \mathrm{~cm} \mathrm{C}-2$ & $-2.5 \mathrm{~cm}$ & $1400 \mathrm{C}$ & $\pm 0.75 \%$ \\
\hline 53 & $\mathrm{~T}$ & TC Type K & Concrete Basemat $+12.5 \mathrm{~cm},+19.7 \mathrm{~cm} \mathrm{C}-3$ & $-7.5 \mathrm{~cm}$ & $1400 \mathrm{C}$ & $\pm 0.75 \%$ \\
\hline 54 & $\mathrm{~T}$ & TC Type K & Concrete Basemat $+12.5 \mathrm{~cm},+19.7 \mathrm{~cm} \mathrm{C}-4$ & $-12.5 \mathrm{~cm}$ & $1400 \mathrm{C}$ & $\pm 0.75 \%$ \\
\hline 55 & $\mathrm{~T}$ & TC Type $\mathrm{K}$ & Concrete Basemat $+12.5 \mathrm{~cm},+19.7 \mathrm{~cm} \mathrm{C}-5$ & $-17.5 \mathrm{~cm}$ & $1400 \mathrm{C}$ & $\pm 0.75 \%$ \\
\hline
\end{tabular}


OECD/MCCI-2009-TR06 Rev. 1

\begin{tabular}{|c|c|c|c|c|c|c|}
\hline 56 & $\mathrm{~T}$ & TC Type K & Concrete Basemat $+12.5 \mathrm{~cm},+19.7 \mathrm{~cm} \mathrm{C}-6$ & $-22.5 \mathrm{~cm}$ & $1400 \mathrm{C}$ & $\pm 0.75 \%$ \\
\hline 57 & $\mathrm{~T}$ & TC Type K & Concrete Basemat $+12.5 \mathrm{~cm},+19.7 \mathrm{~cm} \mathrm{C}-7$ & $-27.5 \mathrm{~cm}$ & $1400 \mathrm{C}$ & $\pm 0.75 \%$ \\
\hline 58 & $\mathrm{~T}$ & TC Type K & Concrete Basemat $+12.5 \mathrm{~cm},+19.7 \mathrm{~cm} \mathrm{C}-8$ & $-35.0 \mathrm{~cm}$ & $1400 \mathrm{C}$ & $\pm 0.75 \%$ \\
\hline 59 & $\mathrm{~T}$ & TC Type K & Concrete Basemat $+12.5 \mathrm{~cm},+19.7 \mathrm{~cm} \mathrm{C}-9$ & $-42.5 \mathrm{~cm}$ & $1400 \mathrm{C}$ & $\pm 0.75 \%$ \\
\hline 60 & $\mathrm{~T}$ & TC Type $\mathrm{C}$ & N Concrete Sidewall, $25.0 \mathrm{~cm}$ deep, centerline WN-7 & $+5.0 \mathrm{~cm}$ & $2320 \mathrm{C}$ & $\pm 1 \%$ \\
\hline 61 & $\mathrm{~T}$ & TC Type K & Concrete Basemat $+12.5 \mathrm{~cm},-19.7 \mathrm{~cm} \mathrm{D}-1$ & $0.0 \mathrm{~cm}$ & $1400 \mathrm{C}$ & $\pm 0.75 \%$ \\
\hline 62 & $\mathrm{~T}$ & TC Type K & Concrete Basemat $+12.5 \mathrm{~cm},-19.7 \mathrm{~cm} \mathrm{D}-2$ & $-2.5 \mathrm{~cm}$ & $1400 \mathrm{C}$ & $\pm 0.75 \%$ \\
\hline 63 & $\mathrm{~T}$ & TC Type K & Concrete Basemat $+12.5 \mathrm{~cm},-19.7 \mathrm{~cm} \mathrm{D}-3$ & $-7.5 \mathrm{~cm}$ & $1400 \mathrm{C}$ & $\pm 0.75 \%$ \\
\hline 64 & $\mathrm{~T}$ & TC Type K & Concrete Basemat $+12.5 \mathrm{~cm},-19.7 \mathrm{~cm} \mathrm{D}-4$ & $-12.5 \mathrm{~cm}$ & $1400 \mathrm{C}$ & $\pm 0.75 \%$ \\
\hline 65 & $\mathrm{~T}$ & TC Type K & Concrete Basemat $+12.5 \mathrm{~cm},-19.7 \mathrm{~cm} \mathrm{D}-5$ & $-17.5 \mathrm{~cm}$ & $1400 \mathrm{C}$ & $\pm 0.75 \%$ \\
\hline 66 & $\mathrm{~T}$ & TC Type K & Concrete Basemat $+12.5 \mathrm{~cm},-19.7 \mathrm{~cm} \mathrm{D}-6$ & $-22.5 \mathrm{~cm}$ & $1400 \mathrm{C}$ & $\pm 0.75 \%$ \\
\hline 67 & $\mathrm{~T}$ & TC Type K & Concrete Basemat $+12.5 \mathrm{~cm},-19.7 \mathrm{~cm} \mathrm{D}-7$ & $-27.5 \mathrm{~cm}$ & $1400 \mathrm{C}$ & $\pm 0.75 \%$ \\
\hline 68 & $\mathrm{~T}$ & TC Type K & Concrete Basemat $+12.5 \mathrm{~cm},-19.7 \mathrm{~cm} \mathrm{D}-8$ & $-35.0 \mathrm{~cm}$ & $1400 \mathrm{C}$ & $\pm 0.75 \%$ \\
\hline 69 & $\mathrm{~T}$ & TC Type K & Concrete Basemat $+12.5 \mathrm{~cm},-19.7 \mathrm{~cm} \mathrm{D}-9$ & $-42.5 \mathrm{~cm}$ & $1400 \mathrm{C}$ & $\pm 0.75 \%$ \\
\hline 70 & $\mathrm{~T}$ & TC Type C & N Concrete Sidewall, $30.0 \mathrm{~cm}$ deep, centerline WN-8 & $+5.0 \mathrm{~cm}$ & $2320 \mathrm{C}$ & $\pm 1 \%$ \\
\hline 71 & $\mathrm{~T}$ & TC Type K & Concrete Basemat $-12.5 \mathrm{~cm},-19.7 \mathrm{~cm} \mathrm{E}-1$ & $0.0 \mathrm{~cm}$ & $1400 \mathrm{C}$ & $\pm 0.75 \%$ \\
\hline 72 & $\mathrm{~T}$ & TC Type K & Concrete Basemat $-12.5 \mathrm{~cm},-19.7 \mathrm{~cm} \mathrm{E-2}$ & $-2.5 \mathrm{~cm}$ & $1400 \mathrm{C}$ & $\pm 0.75 \%$ \\
\hline 73 & $\mathrm{~T}$ & TC Type K & Concrete Basemat $-12.5 \mathrm{~cm},-19.7 \mathrm{~cm} \mathrm{E-3}$ & $-7.5 \mathrm{~cm}$ & $1400 \mathrm{C}$ & $\pm 0.75 \%$ \\
\hline 74 & $\mathrm{~T}$ & TC Type K & Concrete Basemat $-12.5 \mathrm{~cm},-19.7 \mathrm{~cm} \mathrm{E}-4$ & $-12.5 \mathrm{~cm}$ & $1400 \mathrm{C}$ & $\pm 0.75 \%$ \\
\hline 75 & $\mathrm{~T}$ & TC Type K & Concrete Basemat $-12.5 \mathrm{~cm},-19.7 \mathrm{~cm} \mathrm{E}-5$ & $-17.5 \mathrm{~cm}$ & $1400 \mathrm{C}$ & $\pm 0.75 \%$ \\
\hline 76 & $\mathrm{~T}$ & TC Type $\mathrm{K}$ & Concrete Basemat $-12.5 \mathrm{~cm},-19.7 \mathrm{~cm} \mathrm{E-6}$ & $-22.5 \mathrm{~cm}$ & $1400 \mathrm{C}$ & $\pm 0.75 \%$ \\
\hline 77 & $\mathrm{~T}$ & TC Type K & Concrete Basemat $-12.5 \mathrm{~cm},-19.7 \mathrm{~cm} \mathrm{E-7}$ & $-27.5 \mathrm{~cm}$ & $1400 \mathrm{C}$ & $\pm 0.75 \%$ \\
\hline 78 & $\mathrm{~T}$ & TC Type K & Concrete Basemat $-12.5 \mathrm{~cm},-19.7 \mathrm{~cm} \mathrm{E}-8$ & $-35.0 \mathrm{~cm}$ & $1400 \mathrm{C}$ & $\pm 0.75 \%$ \\
\hline 79 & $\mathrm{~T}$ & TC Type K & Concrete Basemat $-12.5 \mathrm{~cm},-19.7 \mathrm{~cm} \mathrm{E-9}$ & $-42.5 \mathrm{~cm}$ & $1400 \mathrm{C}$ & $\pm 0.75 \%$ \\
\hline 80 & Reserve & & & & & \\
\hline 81 & $\mathrm{~T}$ & TC Type K & N Concrete Sidewall $0.0 \mathrm{~cm}$ deep, centerline SWA-1 & $-36.0 \mathrm{~cm}$ & $1400 \mathrm{C}$ & $\pm 0.75 \%$ \\
\hline 82 & $\mathrm{~T}$ & TC Type K & N Concrete Sidewall $2.0 \mathrm{~cm}$ deep, centerline SWA-2 & $-36.0 \mathrm{~cm}$ & $1400 \mathrm{C}$ & $\pm 0.75 \%$ \\
\hline 83 & $\mathrm{~T}$ & TC Type $\mathrm{K}$ & N Concrete Sidewall $6.0 \mathrm{~cm}$ deep, centerline SWA-3 & $-36.0 \mathrm{~cm}$ & $1400 \mathrm{C}$ & $\pm 0.75 \%$ \\
\hline 84 & $\mathrm{~T}$ & TC Type K & N Concrete Sidewall $10.0 \mathrm{~cm}$ deep, centerline SWA-4 & $-36.0 \mathrm{~cm}$ & $1400 \mathrm{C}$ & $\pm 0.75 \%$ \\
\hline
\end{tabular}


OECD/MCCI-2009-TR06 Rev. 1

\begin{tabular}{|c|c|c|c|c|c|c|}
\hline 85 & $\mathrm{~T}$ & TC Type K & N Concrete Sidewall $15.0 \mathrm{~cm}$ deep, centerline SWA-5 & $-36.0 \mathrm{~cm}$ & $1400 \mathrm{C}$ & $\pm 0.75 \%$ \\
\hline 86 & $\mathrm{~T}$ & TC Туре K & N Concrete Sidewall $20.0 \mathrm{~cm}$ deep, centerline SWA-6 & $-36.0 \mathrm{~cm}$ & $1400 \mathrm{C}$ & $\pm 0.75 \%$ \\
\hline 87 & $\mathrm{~T}$ & TC Туре K & N Concrete Sidewall $25.0 \mathrm{~cm}$ deep, centerline SWA-7 & $-36.0 \mathrm{~cm}$ & $1400 \mathrm{C}$ & $\pm 0.75 \%$ \\
\hline 88 & $\mathrm{~T}$ & TC Type K & N Concrete Sidewall $30.0 \mathrm{~cm}$ deep, centerline SWA-8 & $-36.0 \mathrm{~cm}$ & $1400 \mathrm{C}$ & $\pm 0.75 \%$ \\
\hline 89 & $\mathrm{~T}$ & TC Type K & N Concrete Sidewall $0.0 \mathrm{~cm}$ deep, centerline SWB-1 & $-24.0 \mathrm{~cm}$ & $1400 \mathrm{C}$ & $\pm 0.75 \%$ \\
\hline 90 & $\mathrm{~T}$ & TC Type K & N Concrete Sidewall $2.0 \mathrm{~cm}$ deep, centerline SWB-2 & $-24.0 \mathrm{~cm}$ & $1400 \mathrm{C}$ & $\pm 0.75 \%$ \\
\hline 91 & $\mathrm{~T}$ & TC Type K & N Concrete Sidewall $6.0 \mathrm{~cm}$ deep, centerline SWB-3 & $-24.0 \mathrm{~cm}$ & $1400 \mathrm{C}$ & $\pm 0.75 \%$ \\
\hline 92 & $\mathrm{~T}$ & TC Type K & N Concrete Sidewall $10.0 \mathrm{~cm}$ deep, centerline SWB-4 & $-24.0 \mathrm{~cm}$ & $1400 \mathrm{C}$ & $\pm 0.75 \%$ \\
\hline 93 & $\mathrm{~T}$ & TC Type K & N Concrete Sidewall $15.0 \mathrm{~cm}$ deep, centerline SWB-5 & $-24.0 \mathrm{~cm}$ & $1400 \mathrm{C}$ & $\pm 0.75 \%$ \\
\hline 94 & $\mathrm{~T}$ & TC Type K & N Concrete Sidewall $20.0 \mathrm{~cm}$ deep, centerline SWB-6 & $-24.0 \mathrm{~cm}$ & $1400 \mathrm{C}$ & $\pm 0.75 \%$ \\
\hline 95 & $\mathrm{~T}$ & TC Type K & N Concrete Sidewall $25.0 \mathrm{~cm}$ deep, centerline SWB-7 & $-24.0 \mathrm{~cm}$ & $1400 \mathrm{C}$ & $\pm 0.75 \%$ \\
\hline 96 & $\mathrm{~T}$ & TC Type K & N Concrete Sidewall $30.0 \mathrm{~cm}$ deep, centerline SWB-8 & $-24.0 \mathrm{~cm}$ & $1400 \mathrm{C}$ & $\pm 0.75 \%$ \\
\hline 97 & $\mathrm{~T}$ & TC Type K & N Concrete Sidewall $0.0 \mathrm{~cm}$ deep, centerline SWC-1 & $-12.0 \mathrm{~cm}$ & $1400 \mathrm{C}$ & $\pm 0.75 \%$ \\
\hline 98 & $\mathrm{~T}$ & TC Type K & N Concrete Sidewall $2.0 \mathrm{~cm}$ deep, centerline SWC-2 & $-12.0 \mathrm{~cm}$ & $1400 \mathrm{C}$ & $\pm 0.75 \%$ \\
\hline 99 & $\mathrm{~T}$ & TC Type $\mathrm{K}$ & N Concrete Sidewall $6.0 \mathrm{~cm}$ deep, centerline SWC-3 & $-12.0 \mathrm{~cm}$ & $1400 \mathrm{C}$ & $\pm 0.75 \%$ \\
\hline
\end{tabular}

Explanation of Variable Notations

$\mathrm{T}=$ temperature 
OECD/MCCI-2009-TR06 Rev. 1

Table A-2. "Power" DAS Channel Assignments for CCI-5.

\begin{tabular}{|c|c|c|c|c|c|c|}
\hline Channel & Variable & Sensor & Location & Elevation & Range/Limit & Accuracy \\
\hline 00 & Reserve & & & & & \\
\hline 01 & $\mathrm{~T}$ & TC Type K & N Concrete Sidewall $10.0 \mathrm{~cm}$ deep, centerline SWC-4 & $-12.0 \mathrm{~cm}$ & $1400 \mathrm{C}$ & $\pm 0.75 \%$ \\
\hline 02 & $\mathrm{~T}$ & TC Туре K & N Concrete Sidewall $15.0 \mathrm{~cm}$ deep, centerline SWC-5 & $-12.0 \mathrm{~cm}$ & $1400 \mathrm{C}$ & $\pm 0.75 \%$ \\
\hline 03 & $\mathrm{~T}$ & TC Type K & N Concrete Sidewall $20.0 \mathrm{~cm}$ deep, centerline SWC-6 & $-12.0 \mathrm{~cm}$ & $1400 \mathrm{C}$ & $\pm 0.75 \%$ \\
\hline 04 & $\mathrm{~T}$ & TC Type K & N Concrete Sidewall $25.0 \mathrm{~cm}$ deep, centerline SWC-7 & $-12.0 \mathrm{~cm}$ & $1400 \mathrm{C}$ & $\pm 0.75 \%$ \\
\hline 05 & $\mathrm{~T}$ & TC Type K & N Concrete Sidewall $30.0 \mathrm{~cm}$ deep, centerline SWC-8 & $-12.0 \mathrm{~cm}$ & $1400 \mathrm{C}$ & $\pm 0.75 \%$ \\
\hline 06 & $\mathrm{~T}$ & TC Type K & N Concrete Sidewall $35.0 \mathrm{~cm}$ deep, centerline SWC-9 & $-12.0 \mathrm{~cm}$ & $1400 \mathrm{C}$ & $\pm 0.75 \%$ \\
\hline 07 & $\mathrm{~T}$ & TC Type K & N Concrete Sidewall $40.0 \mathrm{~cm}$ deep, centerline SWC-10 & $-12.0 \mathrm{~cm}$ & $1400 \mathrm{C}$ & $\pm 0.75 \%$ \\
\hline 08 & $\mathrm{~T}$ & TC Type K & N Concrete Sidewall $45.0 \mathrm{~cm}$ deep, centerline SWC-11 & $-12.0 \mathrm{~cm}$ & $1400 \mathrm{C}$ & $\pm 0.75 \%$ \\
\hline 09 & $\mathrm{~T}$ & TC Type K & N Concrete Sidewall $0.0 \mathrm{~cm}$ deep, centerline SWD-1 & $0.0 \mathrm{~cm}$ & $1400 \mathrm{C}$ & $\pm 0.75 \%$ \\
\hline 10 & $\mathrm{~T}$ & TC Type K & N Concrete Sidewall $2.0 \mathrm{~cm}$ deep, centerline SWD-2 & $0.0 \mathrm{~cm}$ & $1400 \mathrm{C}$ & $\pm 0.75 \%$ \\
\hline 11 & $\mathrm{~T}$ & TC Type $\mathrm{K}$ & N Concrete Sidewall $6.0 \mathrm{~cm}$ deep, centerline SWD-3 & $0.0 \mathrm{~cm}$ & $1400 \mathrm{C}$ & $\pm 0.75 \%$ \\
\hline 12 & $\mathrm{~T}$ & TC Type K & N Concrete Sidewall $10.0 \mathrm{~cm}$ deep, centerline SWD-4 & $0.0 \mathrm{~cm}$ & $1400 \mathrm{C}$ & $\pm 0.75 \%$ \\
\hline 13 & $\mathrm{~T}$ & TC Type K & N Concrete Sidewall $15.0 \mathrm{~cm}$ deep, centerline SWD-5 & $0.0 \mathrm{~cm}$ & $1400 \mathrm{C}$ & $\pm 0.75 \%$ \\
\hline 14 & $\mathrm{~T}$ & TC Type K & N Concrete Sidewall $20.0 \mathrm{~cm}$ deep, centerline SWD-6 & $0.0 \mathrm{~cm}$ & $1400 \mathrm{C}$ & $\pm 0.75 \%$ \\
\hline 15 & $\mathrm{~T}$ & TC Type K & N Concrete Sidewall $25.0 \mathrm{~cm}$ deep, centerline SWD-7 & $0.0 \mathrm{~cm}$ & $1400 \mathrm{C}$ & $\pm 0.75 \%$ \\
\hline 16 & $\mathrm{~T}$ & TC Type K & N Concrete Sidewall $30.0 \mathrm{~cm}$ deep, centerline SWD-8 & $0.0 \mathrm{~cm}$ & $1400 \mathrm{C}$ & $\pm 0.75 \%$ \\
\hline 17 & $\mathrm{~T}$ & TC Type K & N Concrete Sidewall $35.0 \mathrm{~cm}$ deep, centerline SWD-9 & $0.0 \mathrm{~cm}$ & $1400 \mathrm{C}$ & $\pm 0.75 \%$ \\
\hline 18 & $\mathrm{~T}$ & TC Type K & N Concrete Sidewall $40.0 \mathrm{~cm}$ deep, centerline SWD-10 & $0.0 \mathrm{~cm}$ & $1400 \mathrm{C}$ & $\pm 0.75 \%$ \\
\hline 19 & $\mathrm{~T}$ & TC Type K & N Concrete Sidewall $45.0 \mathrm{~cm}$ deep, centerline SWD-11 & $0.0 \mathrm{~cm}$ & $1400 \mathrm{C}$ & $\pm 0.75 \%$ \\
\hline 20 & $\mathrm{~T}$ & TC Type K & N Concrete Sidewall $0.0 \mathrm{~cm}$ deep, centerline SWE-1 & $+10.0 \mathrm{~cm}$ & $1400 \mathrm{C}$ & $\pm 0.75 \%$ \\
\hline 21 & $\mathrm{~T}$ & TC Type K & N Concrete Sidewall $2.0 \mathrm{~cm}$ deep, centerline SWE-2 & $+10.0 \mathrm{~cm}$ & $1400 \mathrm{C}$ & $\pm 0.75 \%$ \\
\hline 22 & $\mathrm{~T}$ & TC Type K & N Concrete Sidewall $6.0 \mathrm{~cm}$ deep, centerline SWE-3 & $+10.0 \mathrm{~cm}$ & $1400 \mathrm{C}$ & $\pm 0.75 \%$ \\
\hline 23 & $\mathrm{~T}$ & TC Type K & N Concrete Sidewall $10.0 \mathrm{~cm}$ deep, centerline SWE-4 & $+10.0 \mathrm{~cm}$ & $1400 \mathrm{C}$ & $\pm 0.75 \%$ \\
\hline 24 & $\mathrm{~T}$ & TC Type K & N Concrete Sidewall $15.0 \mathrm{~cm}$ deep, centerline SWE-5 & $+10.0 \mathrm{~cm}$ & $1400 \mathrm{C}$ & $\pm 0.75 \%$ \\
\hline 25 & $\mathrm{~T}$ & TC Type K & N Concrete Sidewall $20.0 \mathrm{~cm}$ deep, centerline SWE-6 & $+10.0 \mathrm{~cm}$ & $1400 \mathrm{C}$ & $\pm 0.75 \%$ \\
\hline 26 & $\mathrm{~T}$ & TC Type K & N Concrete Sidewall $25.0 \mathrm{~cm}$ deep, centerline SWE-7 & $+10.0 \mathrm{~cm}$ & $1400 \mathrm{C}$ & $\pm 0.75 \%$ \\
\hline
\end{tabular}


OECD/MCCI-2009-TR06 Rev. 1

\begin{tabular}{|c|c|c|c|c|c|c|}
\hline 27 & $\mathrm{~T}$ & TC Type K & N Concrete Sidewall $30.0 \mathrm{~cm}$ deep, centerline SWE- 8 & $+10.0 \mathrm{~cm}$ & $1400 \mathrm{C}$ & $\pm 0.75 \%$ \\
\hline 28 & $\mathrm{~T}$ & TC Type K & N Concrete Sidewall $35.0 \mathrm{~cm}$ deep, centerline SWE-9 & $+10.0 \mathrm{~cm}$ & $1400 \mathrm{C}$ & $\pm 0.75 \%$ \\
\hline 29 & $\mathrm{~T}$ & TC Type K & N Concrete Sidewall $40.0 \mathrm{~cm}$ deep, centerline SWE-10 & $+10.0 \mathrm{~cm}$ & $1400 \mathrm{C}$ & $\pm 0.75 \%$ \\
\hline 30 & $\mathrm{~T}$ & TC Type K & N Concrete Sidewall $45.0 \mathrm{~cm}$ deep, centerline SWE-11 & $+10.0 \mathrm{~cm}$ & $1400 \mathrm{C}$ & $\pm 0.75 \%$ \\
\hline 31 & $\mathrm{~T}$ & TC Type K & N Concrete Sidewall $0.0 \mathrm{~cm}$ deep, centerline SWF-1 & $+20.0 \mathrm{~cm}$ & $1400 \mathrm{C}$ & $\pm 0.75 \%$ \\
\hline 32 & $\mathrm{~T}$ & TC Type K & N Concrete Sidewall $2.0 \mathrm{~cm}$ deep, centerline SWF-2 & $+20.0 \mathrm{~cm}$ & $1400 \mathrm{C}$ & $\pm 0.75 \%$ \\
\hline 33 & $\mathrm{~T}$ & TC Type K & N Concrete Sidewall $6.0 \mathrm{~cm}$ deep, centerline SWF-3 & $+20.0 \mathrm{~cm}$ & $1400 \mathrm{C}$ & $\pm 0.75 \%$ \\
\hline 34 & $\mathrm{~T}$ & TC Type K & N Concrete Sidewall $10.0 \mathrm{~cm}$ deep, centerline SWF-4 & $+20.0 \mathrm{~cm}$ & $1400 \mathrm{C}$ & $\pm 0.75 \%$ \\
\hline 35 & $\mathrm{~T}$ & TC Type K & N Concrete Sidewall $15.0 \mathrm{~cm}$ deep, centerline SWF-5 & $+20.0 \mathrm{~cm}$ & $1400 \mathrm{C}$ & $\pm 0.75 \%$ \\
\hline 36 & $\mathrm{~T}$ & TC Type K & N Concrete Sidewall $20.0 \mathrm{~cm}$ deep, centerline SWF-6 & $+20.0 \mathrm{~cm}$ & $1400 \mathrm{C}$ & $\pm 0.75 \%$ \\
\hline 37 & $\mathrm{~T}$ & TC Type K & N Concrete Sidewall $25.0 \mathrm{~cm}$ deep, centerline SWF-7 & $+20.0 \mathrm{~cm}$ & $1400 \mathrm{C}$ & $\pm 0.75 \%$ \\
\hline 38 & $\mathrm{~T}$ & TC Type K & N Concrete Sidewall $30.0 \mathrm{~cm}$ deep, centerline SWF- 8 & $+20.0 \mathrm{~cm}$ & $1400 \mathrm{C}$ & $\pm 0.75 \%$ \\
\hline 39 & $\mathrm{~T}$ & TC Type K & N Concrete Sidewall $35.0 \mathrm{~cm}$ deep, centerline SWF-9 & $+20.0 \mathrm{~cm}$ & $1400 \mathrm{C}$ & $\pm 0.75 \%$ \\
\hline 40 & $\mathrm{~T}$ & TC Type K & N Concrete Sidewall $40.0 \mathrm{~cm}$ deep, centerline SWF-10 & $+20.0 \mathrm{~cm}$ & $1400 \mathrm{C}$ & $\pm 0.75 \%$ \\
\hline 41 & $\mathrm{~T}$ & TC Type $\mathrm{K}$ & N Concrete Sidewall $45.0 \mathrm{~cm}$ deep, centerline SWF-11 & $+20.0 \mathrm{~cm}$ & $1400 \mathrm{C}$ & $\pm 0.75 \%$ \\
\hline 42 & $\mathrm{~T}$ & TC Type $\mathrm{K}$ & N Concrete Sidewall $0.0 \mathrm{~cm}$ deep, centerline SWG-1 & $+30.0 \mathrm{~cm}$ & $1400 \mathrm{C}$ & $\pm 0.75 \%$ \\
\hline 43 & $\mathrm{~T}$ & TC Type K & N Concrete Sidewall $5.0 \mathrm{~cm}$ deep, centerline SWG-2 & $+30.0 \mathrm{~cm}$ & $1400 \mathrm{C}$ & $\pm 0.75 \%$ \\
\hline 44 & $\mathrm{~T}$ & TC Type K & N Concrete Sidewall $10.0 \mathrm{~cm}$ deep, centerline SWG-3 & $+30.0 \mathrm{~cm}$ & $1400 \mathrm{C}$ & $\pm 0.75 \%$ \\
\hline 45 & $\mathrm{~T}$ & TC Type K & N Concrete Sidewall $35.0 \mathrm{~cm}$ deep, centerline SWB-9 & $-24.0 \mathrm{~cm}$ & $1400 \mathrm{C}$ & $\pm 0.75 \%$ \\
\hline 46 & $\mathrm{~T}$ & TC Type K & N Concrete Sidewall $40.0 \mathrm{~cm}$ deep, centerline SWB-10 & $-24.0 \mathrm{~cm}$ & $1400 \mathrm{C}$ & $\pm 0.75 \%$ \\
\hline 47 & $\mathrm{~T}$ & TC Type K & N Concrete Sidewall $45.0 \mathrm{~cm}$ deep, centerline SWB-11 & $-24.0 \mathrm{~cm}$ & $1400 \mathrm{C}$ & $\pm 0.75 \%$ \\
\hline 48 & Reserve & & & & & \\
\hline 49 & Reserve & & & & & \\
\hline 50 & $\mathrm{~T}$ & TC Type K & N Concrete Sidewall $0.0 \mathrm{~cm}$ deep, $12.5 \mathrm{~cm} \mathrm{~W}$ of centerline, SWH-1 & $-15.0 \mathrm{~cm}$ & $1400 \mathrm{C}$ & $\pm 0.75 \%$ \\
\hline 51 & $\mathrm{~T}$ & TC Type K & N Concrete Sidewall $5.0 \mathrm{~cm}$ deep, $12.5 \mathrm{~cm} \mathrm{~W}$ of centerline, $\mathrm{SWH}-2$ & $-15.0 \mathrm{~cm}$ & $1400 \mathrm{C}$ & $\pm 0.75 \%$ \\
\hline 52 & $\mathrm{~T}$ & TC Type K & N Concrete Sidewall $10.0 \mathrm{~cm}$ deep, $12.5 \mathrm{~cm} \mathrm{~W}$ of centerline, SWH-3 & $-15.0 \mathrm{~cm}$ & $1400 \mathrm{C}$ & $\pm 0.75 \%$ \\
\hline 53 & $\mathrm{~T}$ & TC Type K & N Concrete Sidewall $20.0 \mathrm{~cm}$ deep, $12.5 \mathrm{~cm}$ W of centerline, SWH-4 & $-15.0 \mathrm{~cm}$ & $1400 \mathrm{C}$ & $\pm 0.75 \%$ \\
\hline 54 & $\mathrm{~T}$ & TC Type K & N Concrete Sidewall $30.0 \mathrm{~cm}$ deep, $12.5 \mathrm{~cm} \mathrm{~W}$ of centerline, SWH-5 & $-15.0 \mathrm{~cm}$ & $1400 \mathrm{C}$ & $\pm 0.75 \%$ \\
\hline 55 & $\mathrm{~T}$ & TC Type K & N Concrete Sidewall $40.0 \mathrm{~cm}$ deep, $12.5 \mathrm{~cm} \mathrm{~W}$ of centerline, SWH-6 & $-15.0 \mathrm{~cm}$ & $1400 \mathrm{C}$ & $\pm 0.75 \%$ \\
\hline
\end{tabular}


OECD/MCCI-2009-TR06 Rev. 1

\begin{tabular}{|c|c|c|c|c|c|c|}
\hline 56 & $\mathrm{~T}$ & TC Type K & N Concrete Sidewall $0.0 \mathrm{~cm}$ deep, $12.5 \mathrm{~cm}$ E of centerline, SWI-1 & $-15.0 \mathrm{~cm}$ & $1400 \mathrm{C}$ & $\pm 0.75 \%$ \\
\hline 57 & $\mathrm{~T}$ & TC Type K & N Concrete Sidewall $5.0 \mathrm{~cm}$ deep, $12.5 \mathrm{~cm}$ E of centerline, SWI-2 & $-15.0 \mathrm{~cm}$ & $1400 \mathrm{C}$ & $\pm 0.75 \%$ \\
\hline 58 & $\mathrm{~T}$ & TC Type K & N Concrete Sidewall $10.0 \mathrm{~cm}$ deep, $12.5 \mathrm{~cm}$ E of centerline, SWI-3 & $-15.0 \mathrm{~cm}$ & $1400 \mathrm{C}$ & $\pm 0.75 \%$ \\
\hline 59 & $\mathrm{~T}$ & TC Type K & N Concrete Sidewall $20.0 \mathrm{~cm}$ deep, $12.5 \mathrm{~cm}$ E of centerline, SWI-4 & $-15.0 \mathrm{~cm}$ & $1400 \mathrm{C}$ & $\pm 0.75 \%$ \\
\hline 60 & $\mathrm{~T}$ & TC Type K & N Concrete Sidewall $30.0 \mathrm{~cm}$ deep, $12.5 \mathrm{~cm}$ E of centerline, SWI-5 & $-15.0 \mathrm{~cm}$ & $1400 \mathrm{C}$ & $\pm 0.75 \%$ \\
\hline 61 & $\mathrm{~T}$ & TC Type K & N Concrete Sidewall $40.0 \mathrm{~cm}$ deep, $12.5 \mathrm{~cm}$ E of centerline, SWI-6 & $-15.0 \mathrm{~cm}$ & $1400 \mathrm{C}$ & $\pm 0.75 \%$ \\
\hline 62 & $\mathrm{~T}$ & TC Type K & N Concrete Sidewall $0.0 \mathrm{~cm}$ deep, $12.5 \mathrm{~cm} \mathrm{~W}$ of centerline, SWJ-1 & $-5.0 \mathrm{~cm}$ & $1400 \mathrm{C}$ & $\pm 0.75 \%$ \\
\hline 63 & $\mathrm{~T}$ & TC Type $\mathrm{K}$ & N Concrete Sidewall $5.0 \mathrm{~cm}$ deep, $12.5 \mathrm{~cm} \mathrm{~W}$ of centerline, SWJ-2 & $-5.0 \mathrm{~cm}$ & $1400 \mathrm{C}$ & $\pm 0.75 \%$ \\
\hline 64 & $\mathrm{~T}$ & TC Type K & N Concrete Sidewall $10.0 \mathrm{~cm}$ deep, $12.5 \mathrm{~cm} \mathrm{~W}$ of centerline, $\mathrm{SWJ}-3$ & $-5.0 \mathrm{~cm}$ & $1400 \mathrm{C}$ & $\pm 0.75 \%$ \\
\hline 65 & $\mathrm{~T}$ & TC Type K & N Concrete Sidewall $20.0 \mathrm{~cm}$ deep, $12.5 \mathrm{~cm} \mathrm{~W}$ of centerline, SWJ-4 & $-5.0 \mathrm{~cm}$ & $1400 \mathrm{C}$ & $\pm 0.75 \%$ \\
\hline 66 & $\mathrm{~T}$ & TC Type $\mathrm{K}$ & N Concrete Sidewall $30.0 \mathrm{~cm}$ deep, $12.5 \mathrm{~cm} \mathrm{~W}$ of centerline, $\mathrm{SWJ}-5$ & $-5.0 \mathrm{~cm}$ & $1400 \mathrm{C}$ & $\pm 0.75 \%$ \\
\hline 67 & $\mathrm{~T}$ & TC Type K & N Concrete Sidewall $40.0 \mathrm{~cm}$ deep, $12.5 \mathrm{~cm} \mathrm{~W}$ of centerline, SWJ-6 & $-5.0 \mathrm{~cm}$ & $1400 \mathrm{C}$ & $\pm 0.75 \%$ \\
\hline 68 & $\mathrm{~T}$ & TC Type K & N Concrete Sidewall $0.0 \mathrm{~cm}$ deep, $12.5 \mathrm{~cm}$ E of centerline, SWK-1 & $-5.0 \mathrm{~cm}$ & $1400 \mathrm{C}$ & $\pm 0.75 \%$ \\
\hline 69 & $\mathrm{~T}$ & TC Type K & N Concrete Sidewall $5.0 \mathrm{~cm}$ deep, $12.5 \mathrm{~cm}$ E of centerline, SWK-2 & $-5.0 \mathrm{~cm}$ & $1400 \mathrm{C}$ & $\pm 0.75 \%$ \\
\hline 70 & $\mathrm{~T}$ & TC Type K & N Concrete Sidewall $10.0 \mathrm{~cm}$ deep, $12.5 \mathrm{~cm}$ E of centerline, SWK-3 & $-5.0 \mathrm{~cm}$ & $1400 \mathrm{C}$ & $\pm 0.75 \%$ \\
\hline 71 & $\mathrm{~T}$ & TC Type K & N Concrete Sidewall $20.0 \mathrm{~cm}$ deep, $12.5 \mathrm{~cm}$ E of centerline, SWK-4 & $-5.0 \mathrm{~cm}$ & $1400 \mathrm{C}$ & $\pm 0.75 \%$ \\
\hline 72 & $\mathrm{~T}$ & TC Type K & N Concrete Sidewall $30.0 \mathrm{~cm}$ deep, $12.5 \mathrm{~cm}$ E of centerline, SWK-5 & $-5.0 \mathrm{~cm}$ & $1400 \mathrm{C}$ & $\pm 0.75 \%$ \\
\hline 73 & $\mathrm{~T}$ & TC Type K & N Concrete Sidewall $40.0 \mathrm{~cm}$ deep, $12.5 \mathrm{~cm}$ E of centerline, SWK-6 & $-5.0 \mathrm{~cm}$ & $1400 \mathrm{C}$ & $\pm 0.75 \%$ \\
\hline 74 & $\mathrm{~T}$ & TC Type K & N Concrete Sidewall $0.0 \mathrm{~cm}$ deep, $12.5 \mathrm{~cm} \mathrm{~W}$ of centerline, SWL-1 & $+5.0 \mathrm{~cm}$ & $1400 \mathrm{C}$ & $\pm 0.75 \%$ \\
\hline 75 & $\mathrm{~T}$ & TC Type K & N Concrete Sidewall $5.0 \mathrm{~cm}$ deep, $12.5 \mathrm{~cm} \mathrm{~W}$ of centerline, SWL-2 & $+5.0 \mathrm{~cm}$ & $1400 \mathrm{C}$ & $\pm 0.75 \%$ \\
\hline 76 & $\mathrm{~T}$ & TC Type K & N Concrete Sidewall $10.0 \mathrm{~cm}$ deep, $12.5 \mathrm{~cm} \mathrm{~W}$ of centerline, SWL-3 & $+5.0 \mathrm{~cm}$ & $1400 \mathrm{C}$ & $\pm 0.75 \%$ \\
\hline 77 & $\mathrm{~T}$ & TC Type K & N Concrete Sidewall $20.0 \mathrm{~cm}$ deep, $12.5 \mathrm{~cm} \mathrm{~W}$ of centerline, SWL-4 & $+5.0 \mathrm{~cm}$ & $1400 \mathrm{C}$ & $\pm 0.75 \%$ \\
\hline 78 & $\mathrm{~T}$ & TC Type K & N Concrete Sidewall $30.0 \mathrm{~cm}$ deep, $12.5 \mathrm{~cm} \mathrm{~W}$ of centerline, SWL-5 & $+5.0 \mathrm{~cm}$ & $1400 \mathrm{C}$ & $\pm 0.75 \%$ \\
\hline 79 & $\mathrm{~T}$ & TC Type $\mathrm{K}$ & N Concrete Sidewall $40.0 \mathrm{~cm}$ deep, $12.5 \mathrm{~cm} \mathrm{~W}$ of centerline, SWL-6 & $+5.0 \mathrm{~cm}$ & $1400 \mathrm{C}$ & $\pm 0.75 \%$ \\
\hline 80 & $\mathrm{~T}$ & TC Type K & N Concrete Sidewall $0.0 \mathrm{~cm}$ deep, $12.5 \mathrm{~cm}$ E of centerline, SWM-1 & $+5.0 \mathrm{~cm}$ & $1400 \mathrm{C}$ & $\pm 0.75 \%$ \\
\hline 81 & $\mathrm{~T}$ & TC Type K & N Concrete Sidewall $5.0 \mathrm{~cm}$ deep, $12.5 \mathrm{~cm}$ E of centerline, SWM-2 & $+5.0 \mathrm{~cm}$ & $1400 \mathrm{C}$ & $\pm 0.75 \%$ \\
\hline 82 & $\mathrm{~T}$ & TC Type K & N Concrete Sidewall $10.0 \mathrm{~cm}$ deep, $12.5 \mathrm{~cm}$ E of centerline, SWM-3 & $+5.0 \mathrm{~cm}$ & $1400 \mathrm{C}$ & $\pm 0.75 \%$ \\
\hline 83 & $\mathrm{~T}$ & TC Type K & N Concrete Sidewall $20.0 \mathrm{~cm}$ deep, $12.5 \mathrm{~cm}$ E of centerline, SWM-4 & $+5.0 \mathrm{~cm}$ & $1400 \mathrm{C}$ & $\pm 0.75 \%$ \\
\hline 84 & $\mathrm{~T}$ & TC Type K & N Concrete Sidewall $30.0 \mathrm{~cm}$ deep, $12.5 \mathrm{~cm}$ E of centerline, SWM-5 & $+5.0 \mathrm{~cm}$ & $1400 \mathrm{C}$ & $\pm 0.75 \%$ \\
\hline
\end{tabular}


OECD/MCCI-2009-TR06 Rev. 1

\begin{tabular}{|c|c|c|c|c|c|c|}
\hline 85 & $\mathrm{~T}$ & TC Type K & N Concrete Sidewall $40.0 \mathrm{~cm}$ deep, $12.5 \mathrm{~cm}$ E of centerline, SWM-6 & $+5.0 \mathrm{~cm}$ & $1400 \mathrm{C}$ & $\pm 0.75 \%$ \\
\hline 86 & $\mathrm{~T}$ & TC Type K & N Concrete Sidewall $0.0 \mathrm{~cm}$ deep, $12.5 \mathrm{~cm} \mathrm{~W}$ of centerline, $\mathrm{SWN}-1$ & $+15.0 \mathrm{~cm}$ & $1400 \mathrm{C}$ & $\pm 0.75 \%$ \\
\hline 87 & $\mathrm{~T}$ & TC Type K & N Concrete Sidewall $5.0 \mathrm{~cm}$ deep, $12.5 \mathrm{~cm} \mathrm{~W}$ of centerline, SWN-2 & $+15.0 \mathrm{~cm}$ & $1400 \mathrm{C}$ & $\pm 0.75 \%$ \\
\hline 88 & $\mathrm{~T}$ & TC Type K & N Concrete Sidewall $10.0 \mathrm{~cm}$ deep, $12.5 \mathrm{~cm} \mathrm{~W}$ of centerline, $\mathrm{SWN}-3$ & $+15.0 \mathrm{~cm}$ & $1400 \mathrm{C}$ & $\pm 0.75 \%$ \\
\hline 89 & $\mathrm{~T}$ & TC Type K & N Concrete Sidewall $20.0 \mathrm{~cm}$ deep, $12.5 \mathrm{~cm} \mathrm{~W}$ of centerline, SWN-4 & $+15.0 \mathrm{~cm}$ & $1400 \mathrm{C}$ & $\pm 0.75 \%$ \\
\hline 90 & $\mathrm{~T}$ & TC Type K & N Concrete Sidewall $30.0 \mathrm{~cm}$ deep, $12.5 \mathrm{~cm} \mathrm{~W}$ of centerline, SWN-5 & $+15.0 \mathrm{~cm}$ & $1400 \mathrm{C}$ & $\pm 0.75 \%$ \\
\hline 91 & $\mathrm{~T}$ & TC Type K & N Concrete Sidewall $40.0 \mathrm{~cm}$ deep, $12.5 \mathrm{~cm} \mathrm{~W}$ of centerline, SWN-6 & $+15.0 \mathrm{~cm}$ & $1400 \mathrm{C}$ & $\pm 0.75 \%$ \\
\hline 92 & $\mathrm{~T}$ & TC Type K & N Concrete Sidewall $0.0 \mathrm{~cm}$ deep, $12.5 \mathrm{~cm}$ E of centerline, SWO-1 & $+15.0 \mathrm{~cm}$ & $1400 \mathrm{C}$ & $\pm 0.75 \%$ \\
\hline 93 & $\mathrm{~T}$ & TC Type K & N Concrete Sidewall $5.0 \mathrm{~cm}$ deep, $12.5 \mathrm{~cm}$ E of centerline, SWO-2 & $+15.0 \mathrm{~cm}$ & $1400 \mathrm{C}$ & $\pm 0.75 \%$ \\
\hline 94 & $\mathrm{~T}$ & TC Type K & N Concrete Sidewall $10.0 \mathrm{~cm}$ deep, $12.5 \mathrm{~cm}$ E of centerline, SWO-3 & $+15.0 \mathrm{~cm}$ & $1400 \mathrm{C}$ & $\pm 0.75 \%$ \\
\hline 95 & $\mathrm{~T}$ & TC Type K & N Concrete Sidewall $20.0 \mathrm{~cm}$ deep, $12.5 \mathrm{~cm}$ E of centerline, SWO-4 & $+15.0 \mathrm{~cm}$ & $1400 \mathrm{C}$ & $\pm 0.75 \%$ \\
\hline 96 & $\mathrm{~T}$ & TC Type K & N Concrete Sidewall $30.0 \mathrm{~cm}$ deep, $12.5 \mathrm{~cm}$ E of centerline, SWO-5 & $+15.0 \mathrm{~cm}$ & $1400 \mathrm{C}$ & $\pm 0.75 \%$ \\
\hline 97 & $\mathrm{~T}$ & TC Type K & N Concrete Sidewall $40.0 \mathrm{~cm}$ deep, $12.5 \mathrm{~cm}$ E of centerline, SWO-6 & $+15.0 \mathrm{~cm}$ & $1400 \mathrm{C}$ & $\pm 0.75 \%$ \\
\hline 98 & Reserve & & & & & \\
\hline 99 & Reserve & & & & & \\
\hline
\end{tabular}

Explanation of Variable Notations

$\mathrm{T}=$ temperature 
OECD/MCCI-2009-TR06 Rev. 1

Table A-3. "Quench" DAS Channel Assignments for CCI-5.

\begin{tabular}{|c|c|c|c|c|c|c|c|}
\hline Channel & Variable & Sensor & Location & Level & Range/Limit & Accuracy & Notes \\
\hline 00 & $\mathrm{~T}$ & Diode Sensor & TC Compensation CH Q00-Q49 & & $130 \mathrm{C}$ & & \\
\hline 01 & $\mathrm{~T}$ & TC Type C & S MgO Sidewall, Lower Section, $0.0 \mathrm{~cm}$ deep SWHL-17 & $+10.0 \mathrm{~cm}$ & $2320 \mathrm{C}$ & $\pm 1.0 \%$ & \\
\hline 02 & $\mathrm{~T}$ & TC Type C & S MgO Sidewall, Lower Section, $1.0 \mathrm{~cm}$ deep SWHL-18 & $+10.0 \mathrm{~cm}$ & $2320 \mathrm{C}$ & $\pm 1.0 \%$ & \\
\hline 03 & $\mathrm{~T}$ & TC Type C & S MgO Sidewall, Lower Section, $3.0 \mathrm{~cm}$ deep SWHL-19 & $+10.0 \mathrm{~cm}$ & $2320 \mathrm{C}$ & $\pm 1.0 \%$ & \\
\hline 04 & $\mathrm{~T}$ & TC Type C & E MgO Sidewall, Lower Section, $1.0 \mathrm{~cm}$ deep SWHL-1 & $-17.5 \mathrm{~cm}$ & $2320 \mathrm{C}$ & $\pm 1.0 \%$ & \\
\hline 05 & $\mathrm{~T}$ & TC Type C & E MgO Sidewall, Lower Section, $2.0 \mathrm{~cm}$ deep SWHL-2 & $-17.5 \mathrm{~cm}$ & $2320 \mathrm{C}$ & $\pm 1.0 \%$ & \\
\hline 06 & $\mathrm{~T}$ & TC Type C & E MgO Sidewall, Lower Section, $4.0 \mathrm{~cm}$ deep SWHL-3 & $-17.5 \mathrm{~cm}$ & $2320 \mathrm{C}$ & $\pm 1.0 \%$ & \\
\hline 07 & $\mathrm{~T}$ & TC Type C & E MgO Sidewall, Lower Section, $8.0 \mathrm{~cm}$ deep SWHL-4 & $-17.5 \mathrm{~cm}$ & $2320 \mathrm{C}$ & $\pm 1.0 \%$ & \\
\hline 08 & $\mathrm{~T}$ & TC Type C & W MgO Sidewall, Lower Section, $1.0 \mathrm{~cm}$ deep SWHL-9 & $-7.5 \mathrm{~cm}$ & $2320 \mathrm{C}$ & $\pm 1.0 \%$ & \\
\hline 09 & $\mathrm{~T}$ & TC Type C & W MgO Sidewall, Lower Section, $2.0 \mathrm{~cm}$ deep SWHL-10 & $-7.5 \mathrm{~cm}$ & $2320 \mathrm{C}$ & $\pm 1.0 \%$ & \\
\hline 10 & $\mathrm{~T}$ & TC Type C & W MgO Sidewall, Lower Section, $4.0 \mathrm{~cm}$ deep SWHL-11 & $-7.5 \mathrm{~cm}$ & $2320 \mathrm{C}$ & $\pm 1.0 \%$ & \\
\hline 11 & $\mathrm{~T}$ & TC Type C & W MgO Sidewall, Lower Section, 8.0 cm deep SWHL-12 & $-7.5 \mathrm{~cm}$ & $2320 \mathrm{C}$ & $\pm 1.0 \%$ & \\
\hline 12 & $\mathrm{~T}$ & TC Type C & E MgO Sidewall, Lower Section, $1.0 \mathrm{~cm}$ deep SWHL-13 & $+2.5 \mathrm{~cm}$ & $2320 \mathrm{C}$ & $\pm 1.0 \%$ & \\
\hline 13 & $\mathrm{~T}$ & TC Type C & E MgO Sidewall, Lower Section, $2.0 \mathrm{~cm}$ deep SWHL-14 & $+2.5 \mathrm{~cm}$ & $2320 \mathrm{C}$ & $\pm 1.0 \%$ & \\
\hline 14 & $\mathrm{~T}$ & TC Type C & E MgO Sidewall, Lower Section, $4.0 \mathrm{~cm}$ deep SWHL-15 & $+2.5 \mathrm{~cm}$ & $2320 \mathrm{C}$ & $\pm 1.0 \%$ & \\
\hline 15 & $\mathrm{~T}$ & TC Type C & E MgO Sidewall, Lower Section, $8.0 \mathrm{~cm}$ deep SWHL-16 & $+2.5 \mathrm{~cm}$ & $2320 \mathrm{C}$ & $\pm 1.0 \%$ & \\
\hline 16 & $\mathrm{~T}$ & TC Type C & W MgO Sidewall, Lower Section, $1.0 \mathrm{~cm}$ deep SWHL-21 & $+12.5 \mathrm{~cm}$ & $2320 \mathrm{C}$ & $\pm 1.0 \%$ & \\
\hline 17 & $\mathrm{~T}$ & TC Type C & W MgO Sidewall, Lower Section, $2.0 \mathrm{~cm}$ deep SWHL-22 & $+12.5 \mathrm{~cm}$ & $2320 \mathrm{C}$ & $\pm 1.0 \%$ & \\
\hline 18 & $\mathrm{~T}$ & TC Type C & W MgO Sidewall, Lower Section, $4.0 \mathrm{~cm}$ deep SWHL-23 & $+12.5 \mathrm{~cm}$ & $2320 \mathrm{C}$ & $\pm 1.0 \%$ & \\
\hline 19 & $\mathrm{~T}$ & TC Type C & W MgO Sidewall, Lower Section, $8.0 \mathrm{~cm}$ deep SWHL-24 & $+12.5 \mathrm{~cm}$ & $2320 \mathrm{C}$ & $\pm 1.0 \%$ & \\
\hline 20 & $\mathrm{~L}$ & Potentiometer & Lance Position Indicator & & $0-125 \mathrm{~cm}$ & & \\
\hline 21 & $\mathrm{~T}$ & TC Type K & Steamline internal vertical run from vessel ML-1 & & $1400 \mathrm{C}$ & $\pm 0.75 \%$ & \\
\hline 22 & $\mathrm{~T}$ & TC Type K & Steamline external vertical run from vessel ML-2 & & $1400 \mathrm{C}$ & $\pm 0.75 \%$ & \\
\hline 23 & $\mathrm{~T}$ & TC Type K & Steamline external lateral run from vessel ML-3 & & $1400 \mathrm{C}$ & $\pm 0.75 \%$ & \\
\hline 24 & $\mathrm{~T}$ & TC Type K & Steamline external vertical run to quench tank ML-4 & & $1400 \mathrm{C}$ & $\pm 0.75 \%$ & \\
\hline 25 & $\mathrm{~T}$ & TC Type $\mathrm{K}$ & S Middle Section Sidewall, $0.0 \mathrm{~cm}$ deep SWHL-25 & $+67.5 \mathrm{~cm}$ & $1400 \mathrm{C}$ & $\pm 0.75 \%$ & \\
\hline 26 & & & & & & $\pm 0.75 \%$ & \\
\hline
\end{tabular}


OECD/MCCI-2009-TR06 Rev. 1

\begin{tabular}{|c|c|c|c|c|c|c|c|}
\hline & $\mathrm{T}$ & TC Type K & S Middle Section Sidewall, $20.0 \mathrm{~cm}$ deep SWHL-26 & $+67.5 \mathrm{~cm}$ & $1400 \mathrm{C}$ & & \\
\hline 27 & $\mathrm{~T}$ & TC Type K & N Top Section Sidewall, $0.0 \mathrm{~cm}$ deep SWHL -37 & $+193.0 \mathrm{~cm}$ & $1400 \mathrm{C}$ & $\pm 0.75 \%$ & \\
\hline 28 & FOR & Strain & $\begin{array}{l}\text { Crust Force Load } \\
\end{array}$ & & $0-44.6 \mathrm{kN}$ & & \\
\hline 29 & $\mathrm{~T}$ & TC Type K & Quench tank internal QT-1 & $21 \mathrm{~cm}$ & $1400 \mathrm{C}$ & $\pm 0.75 \%$ & \\
\hline 30 & $\mathrm{~T}$ & TC Type K & Quench tank internal QT-2 & $55 \mathrm{~cm}$ & $1400 \mathrm{C}$ & $\pm 0.75 \%$ & \\
\hline 31 & $\mathrm{~T}$ & TC Type C & S MgO Sidewall, Lower Section, $0.0 \mathrm{~cm}$ deep SWHL-5 & $-10.0 \mathrm{~cm}$ & $2320 \mathrm{C}$ & $\pm 1.0 \%$ & \\
\hline 32 & $\mathrm{~T}$ & TC Type C & S MgO Sidewall, Lower Section, $1.0 \mathrm{~cm}$ deep SWHL-6 & $-10.0 \mathrm{~cm}$ & $2320 \mathrm{C}$ & $\pm 1.0 \%$ & \\
\hline 33 & $\mathrm{~T}$ & TC Type C & S MgO Sidewall, Lower Section, $3.0 \mathrm{~cm}$ deep SWHL-7 & $-10.0 \mathrm{~cm}$ & $2320 \mathrm{C}$ & $\pm 1.0 \%$ & \\
\hline 34 & $\mathrm{~T}$ & TC Type C & S MgO Sidewall, Lower Section, $7.0 \mathrm{~cm}$ deep SWHL-8 & $-10.0 \mathrm{~cm}$ & $2320 \mathrm{C}$ & $\pm 1.0 \%$ & \\
\hline 35 & $\mathrm{~T}$ & TC Type K & Quench tank coil inlet QT-5 & & $1400 \mathrm{C}$ & $\pm 0.75 \%$ & \\
\hline 36 & $\mathrm{~T}$ & TC Type K & Quench tank coil outlet QT-6 & & $1400 \mathrm{C}$ & $\pm 0.75 \%$ & \\
\hline 37 & $\mathrm{~T}$ & TC Type K & Quench tank coil outlet QT-7 & & $1400 \mathrm{C}$ & $\pm 0.75 \%$ & \\
\hline 38 & $\mathrm{~T}$ & TC Type K & Overflow tank internal OT-1 & $16 \mathrm{~cm}$ & $1400 \mathrm{C}$ & $\pm 0.75 \%$ & \\
\hline 39 & $\mathrm{~T}$ & Voltage & Igniter Current & & $100 \mathrm{mV}$ & & \\
\hline 40 & $\mathrm{~T}$ & TC Type K & Spray tank internal ST-1 & $10 \mathrm{~cm}$ & $1400 \mathrm{C}$ & $\pm 0.75 \%$ & \\
\hline 41 & $\mathrm{~T}$ & TC Type C & S MgO Sidewall, Lower Section, $7.0 \mathrm{~cm}$ deep SWHL-20 & $+10.0 \mathrm{~cm}$ & $2320 \mathrm{C}$ & $\pm 1.0 \%$ & \\
\hline 42 & $\mathrm{~T}$ & TC Type K & N Top Section Sidewall, $2.0 \mathrm{~cm}$ deep SWHL-38 & $+193.0 \mathrm{~cm}$ & $1400 \mathrm{C}$ & $\pm 0.75 \%$ & \\
\hline 43 & $\mathrm{~T}$ & TC Type K & N Middle Section Sidewall, $0.0 \mathrm{~cm}$ deep SWHL-29 & $+92.2 \mathrm{~cm}$ & $1400 \mathrm{C}$ & $\pm 0.75 \%$ & \\
\hline 44 & $\mathrm{~T}$ & TC Type K & N Middle Section Sidewall, $2.0 \mathrm{~cm}$ deep SWHL-30 & $+92.2 \mathrm{~cm}$ & $1400 \mathrm{C}$ & $\pm 0.75 \%$ & \\
\hline 45 & $\mathrm{~T}$ & TC Type K & W Top Section Sidewall $0.0 \mathrm{~cm}$ deep SWHL-39 & $+211.3 \mathrm{~cm}$ & $1400 \mathrm{C}$ & $\pm 0.75 \%$ & \\
\hline 46 & $\mathrm{~T}$ & TC Type K & W Top Section Sidewall $2.0 \mathrm{~cm}$ deep SWHL-40 & $+211.3 \mathrm{~cm}$ & $1400 \mathrm{C}$ & $\pm 0.75 \%$ & \\
\hline 47 & $\mathrm{~T}$ & TC Type K & S Middle Section Sidewall $0.0 \mathrm{~cm}$ deep SWHL-33 & $+148.8 \mathrm{~cm}$ & $1400 \mathrm{C}$ & $\pm 0.75 \%$ & \\
\hline 48 & $\mathrm{~T}$ & TC Type K & S Middle Section Sidewall $2.0 \mathrm{~cm}$ deep SWHL-34 & $+148.8 \mathrm{~cm}$ & $1400 \mathrm{C}$ & $\pm 0.75 \%$ & \\
\hline 49 & Reserve & & & & & & \\
\hline 50 & $\mathrm{~T}$ & Diode Sensor & TC Compensation CH Q50-Q99 & & $130 \mathrm{C}$ & & \\
\hline 51 & $\mathrm{~T}$ & TC Type K & E Top Section Sidewall $0.0 \mathrm{~cm}$ deep SWHL-35 & $+174.7 \mathrm{~cm}$ & $1400 \mathrm{C}$ & $\pm 0.75 \%$ & \\
\hline 52 & $\mathrm{~T}$ & TC Type K & E Top Section Sidewall $2.0 \mathrm{~cm}$ deep SWHL-36 & $+174.7 \mathrm{~cm}$ & $1400 \mathrm{C}$ & $\pm 0.75 \%$ & \\
\hline 53 & Reserve & & & & & & \\
\hline 54 & & & Internal, exhaust line OG-1 & & $1400 \mathrm{C}$ & $\pm 0.75 \%$ & \\
\hline
\end{tabular}


OECD/MCCI-2009-TR06 Rev. 1

\begin{tabular}{|c|c|c|c|c|c|c|c|}
\hline & $\mathrm{T}$ & TC Type K & & & & & \\
\hline 55 & $\mathrm{~T}$ & TC Type K & Water Supply Tank Internal WS-1 & & $1400 \mathrm{C}$ & $\pm 0.75 \%$ & \\
\hline 56 & & $\begin{array}{c}\text { Optical } \\
\text { Pyrometer }\end{array}$ & Corium Surface Temperature OP-1 & $242.9 \mathrm{~cm}$ & $600-1800 \mathrm{C}$ & $\pm 4.0 \mathrm{C}$ & \\
\hline 57 & $\mathrm{~T}$ & TC Type K & Water level probe LP-1 & $167 / 48 \mathrm{~cm}$ & $1400 \mathrm{C}$ & $\pm 0.75 \%$ & \\
\hline 58 & $\mathrm{~T}$ & TC Type K & Water level probe LP-2 & $167 / 48 \mathrm{~cm}$ & $1400 \mathrm{C}$ & $\pm 0.75 \%$ & \\
\hline 59 & $\mathrm{~T}$ & TC Type K & Test vessel plenum gas TS-1 & $223.0 \mathrm{~cm}$ & $1400 \mathrm{C}$ & $\pm 0.75 \%$ & \\
\hline 60 & $\mathrm{~L}$ & Strain & Supply tank head PT-1 & & $350-20001$ & & D-6 \\
\hline 61 & $\mathrm{P}$ & Strain & Supply tank pressure PT-2 & & $0-204 \mathrm{kPa}$ & & A-17 \\
\hline 62 & $\mathrm{~L}$ & Strain & Test vessel head, insertion probe PT-3 & & $63-1501$ & & $\mathrm{D}-3$ \\
\hline 63 & $\mathrm{~L}$ & Strain & Test vessel head, static probe PT-4 & & $32-1501$ & & D-1 \\
\hline 64 & $\mathrm{P}$ & Strain & Test vessel plenum pressure PT-5 & & $0-204 \mathrm{kPa}$ & & A-1 \\
\hline 65 & $\mathrm{P}$ & Strain & Basemat side pressure PT-6 & & $0-204 \mathrm{kPa}$ & & A-3 \\
\hline 66 & Reserve & & & & & & \\
\hline 67 & $\mathrm{~L}$ & Strain & Quench tank head PT-8 & & $80-5901$ & & D-9 \\
\hline 68 & $\mathrm{P}$ & Strain & Quench/overflow tank pressure PT-9 & & $0-35 \mathrm{kPad}$ & & $\mathrm{D}-2$ \\
\hline 69 & $\mathrm{~L}$ & Strain & Overflow tank head PT-10 & & $200-9001$ & & D-8 \\
\hline 70 & $\mathrm{~L}$ & Strain & Spray tank head PT-11 & & $240-12901$ & & D-5 \\
\hline 71 & $\mathrm{P}$ & Strain & Spray tank pressure PT-12 & & $0-35 \mathrm{kPad}$ & & D-4 \\
\hline 72 & $\mathrm{~L}$ & Magnetic Float & Supply tank volume LS-1 & & $350-20001$ & & \\
\hline 73 & $\mathrm{~L}$ & Magnetic Float & Quench tank volume LS-2 & & $80-5901$ & & \\
\hline 74 & $\mathrm{~L}$ & Magnetic Float & Overflow tank volume LS-3 & & $200-9001$ & & \\
\hline 75 & $\mathrm{~L}$ & Magnetic Float & Spray tank volume LS-4 & & 240-1290 1 & & \\
\hline 76 & $\mathrm{~F}$ & Paddlewheel & Water supply flowrate FM-1 & & $680 \mathrm{lpm}$ & & \\
\hline 77 & $\mathrm{~F}$ & Paddlewheel & Quench tank coil flowrate FM-2 & & $190 \mathrm{lpm}$ & & \\
\hline 78 & Reserve & & & & & & \\
\hline 79 & $\mathrm{~T}$ & TC Type K & S Top Section Sidewall $0.0 \mathrm{~cm}$ deep SWHL-41 & $+229.6 \mathrm{~cm}$ & $1400 \mathrm{C}$ & $\pm 0.75 \%$ & \\
\hline 80 & $\mathrm{~T}$ & TC Type K & S Top Section Sidewall $2.0 \mathrm{~cm}$ deep SWHL-42 & $+229.6 \mathrm{~cm}$ & $1400 \mathrm{C}$ & $\pm 0.75 \%$ & \\
\hline 81 & $\mathrm{FC}$ & Flowcontroller & Final Offgas Flowrate FC1a & & $0-3,000 \mathrm{lpm}$ & & \\
\hline
\end{tabular}


OECD/MCCI-2009-TR06 Rev. 1

\begin{tabular}{|c|c|c|c|c|c|c|c|}
\hline 82 & & - & Calculated Water Volume in Test Section & & $0-1501$ & & \\
\hline 83 & FC & Flowcontroller & Lid lights \& camera covergas flowrate FC-2 & & $0-200 \mathrm{lpm}$ & & \\
\hline 84 & Reserve & & & & & & \\
\hline 85 & & - & Calculated Total Current (Q92+Q93) & & $0-10,000 \mathrm{~A}$ & & \\
\hline 86 & & - & Calculated Total Power (Q94+Q95) & & $0-500 \mathrm{~kW}$ & & \\
\hline 87 & $\mathrm{FC}$ & Flowcontroller & Test vessel covergas flowrate FC-6 & & $0-100 \mathrm{lpm}$ & & \\
\hline 88 & $\mathrm{FC}$ & Flowcontroller & Lid camera covergas flowrate FC-7 & & $0-350 \mathrm{lpm}$ & & \\
\hline 89 & $\mathrm{~V}$ & & Pressure transducer power supply \#1 voltage & & $0-30 \mathrm{~V}$ & & \\
\hline 90 & $\mathrm{~V}$ & & Pressure transducer power supply \#2 voltage & & $0-30 \mathrm{~V}$ & & \\
\hline 91 & $\mathrm{~V}$ & Voltmeter & Power supply voltage & & $0-200 \mathrm{~V}$ & & \\
\hline 92 & A & Transformer & Power supply current \#2 & & $5000 \mathrm{~A}$ & & \\
\hline 93 & A & Transformer & Power supply current \#1 & & $5000 \mathrm{~A}$ & & \\
\hline 94 & W & Hall Meter & Power supply power \#2 & & $1100 \mathrm{~kW}$ & & \\
\hline 95 & $\mathrm{~W}$ & Hall Meter & Power supply power \#1 & & $1100 \mathrm{~kW}$ & & \\
\hline 96 & $\mathrm{~L}$ & Strain & Auxiliary Tank Head PT-13 & & $366-4080$ & & D-10 \\
\hline 97 & $\mathrm{~T}$ & TC Type K & Auxiliary Tank Internal AT-1 & $43 \mathrm{~cm}$ & $1400 \mathrm{C}$ & $\pm 0.75 \%$ & \\
\hline 98 & Reserve & & & & & & \\
\hline 99 & Reserve & & & & & & \\
\hline
\end{tabular}

Explanation of variable notations

$\mathrm{T}=$ temperature $\mathrm{P}=$ Pressure FOR=Force $\mathrm{L}=$ Level $\mathrm{V}=$ Voltage $\mathrm{F}=$ Flowrate $\mathrm{A}=$ Current $\mathrm{W}=$ Power $\mathrm{FC}=\mathrm{Flow}$ Controller 
OECD/MCCI-2009-TR06 Rev. 1

\section{APPENDIX B \\ Test Data}

This Appendix provides plots of all data recorded during Test CCI-5. The complete channel assignment list is provided in Appendix A. Time $\mathrm{t}=0$ in all plots is referenced to the time at which ablation had been initiated on the concrete basemat and sidewall. This corresponds to 6.0 minutes after onset of data acquisition; see Table 3-1. All data was logged at $\sim 5.5$ second time intervals during the test. The data have been averaged over 30 second intervals to improve readability. 
OECD/MCCI-2009-TR06 Rev. 1

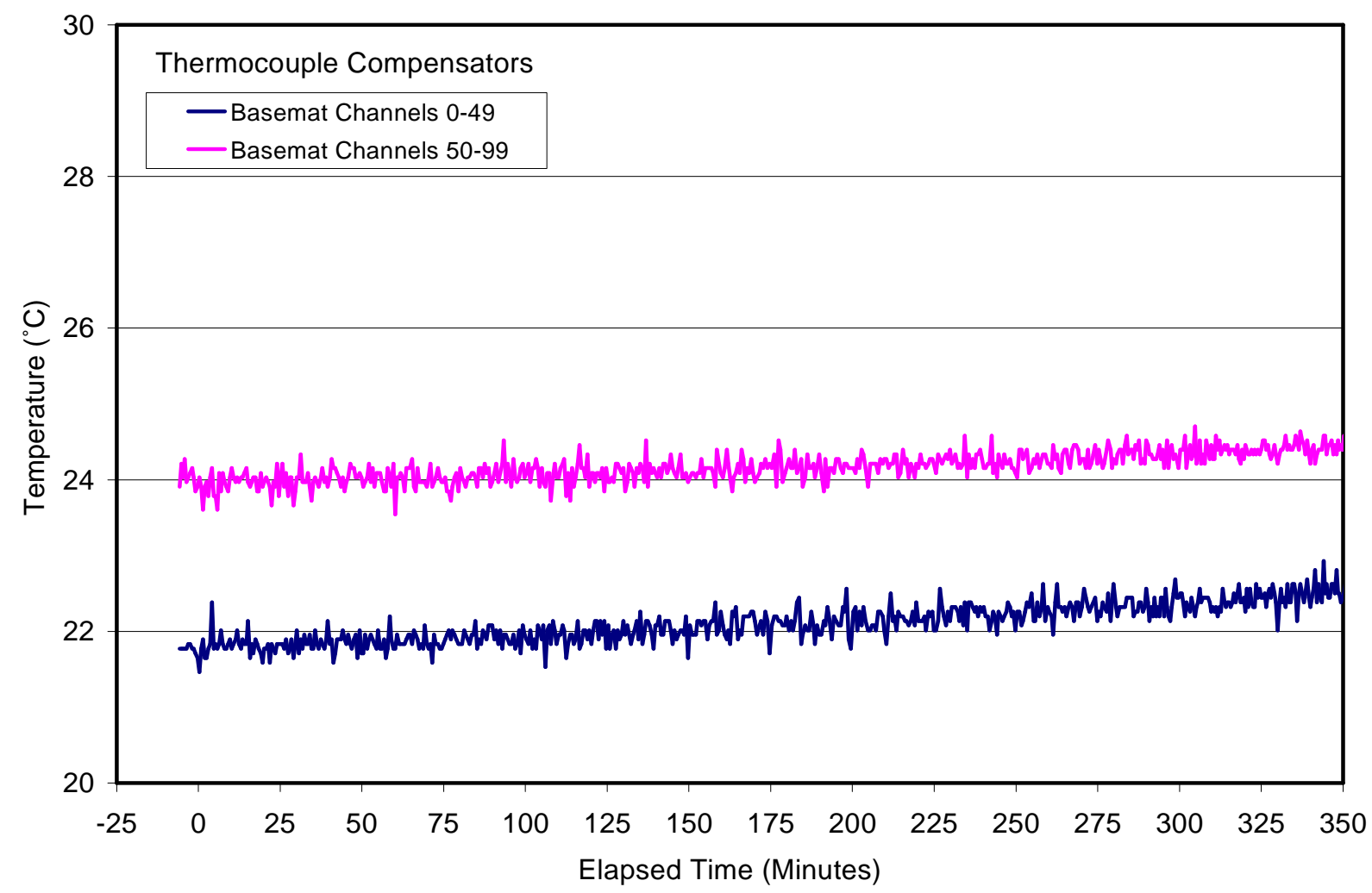

Figure B-1. Compensator Temperature, Channels B0-B49 and B50-B99.

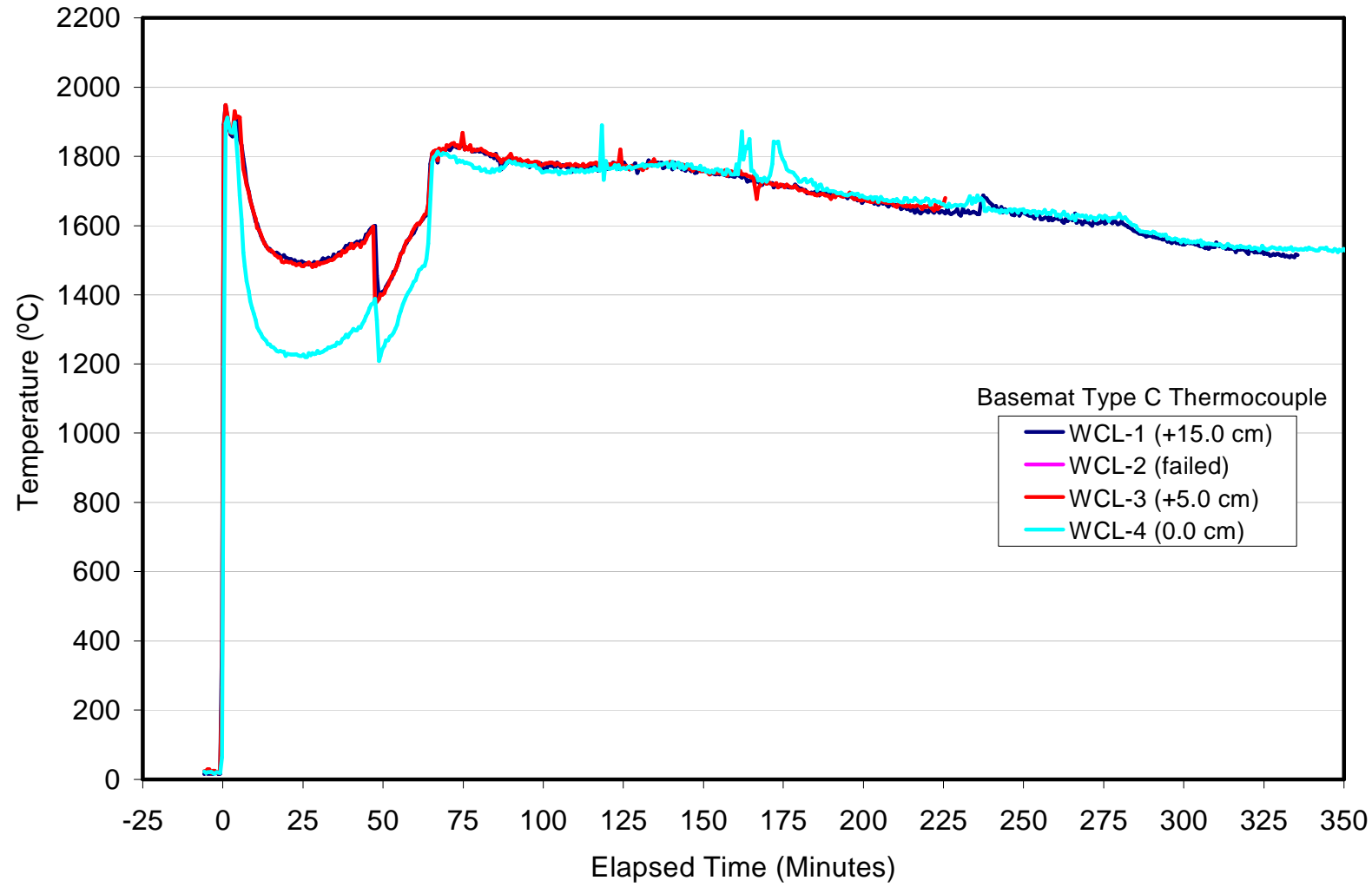

Figure B-2. Basemat Type C "WCL" Array Data. 
OECD/MCCI-2009-TR06 Rev. 1

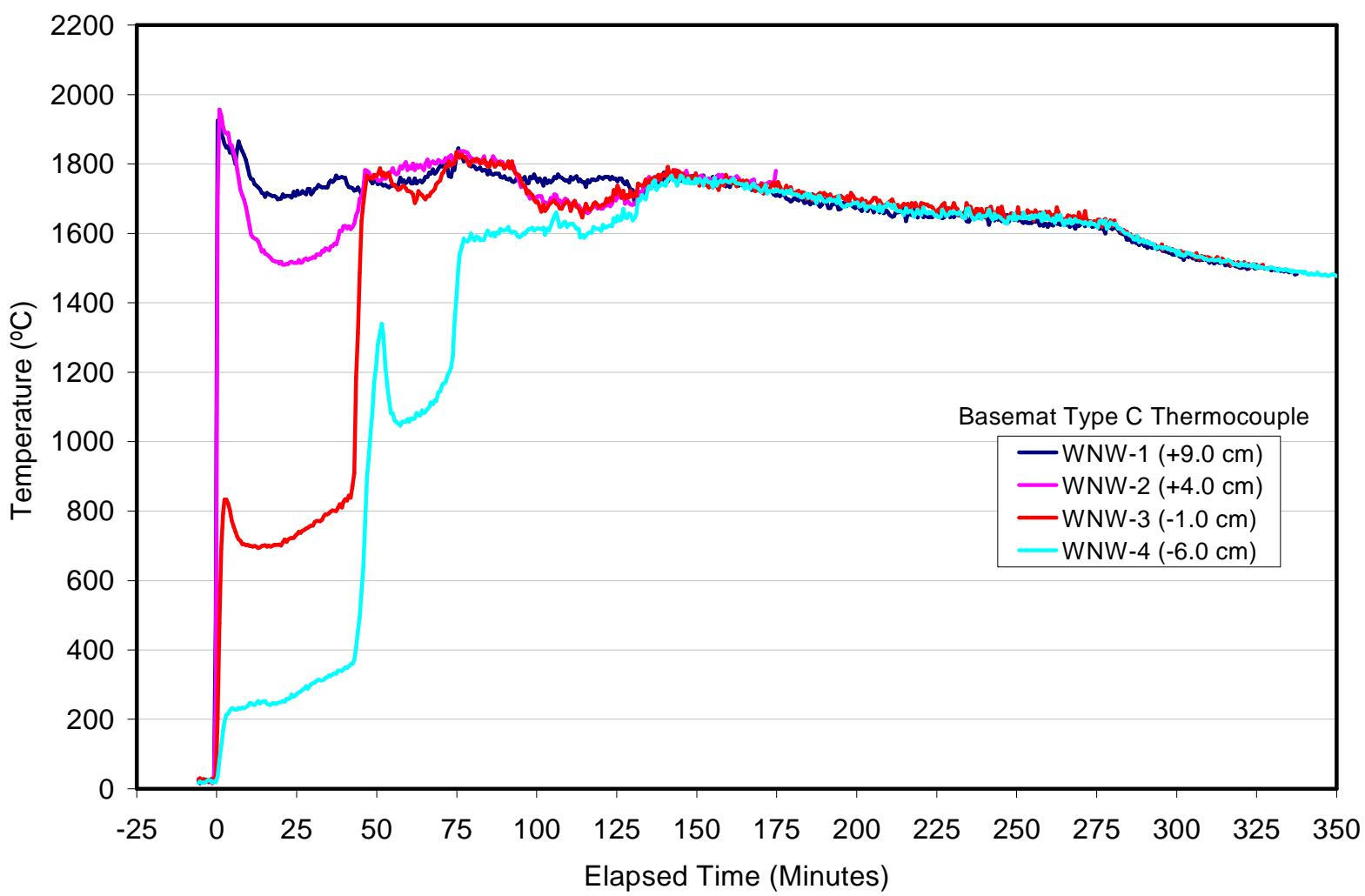

Figure B-3. Basemat Type C "WNW" Array Data.

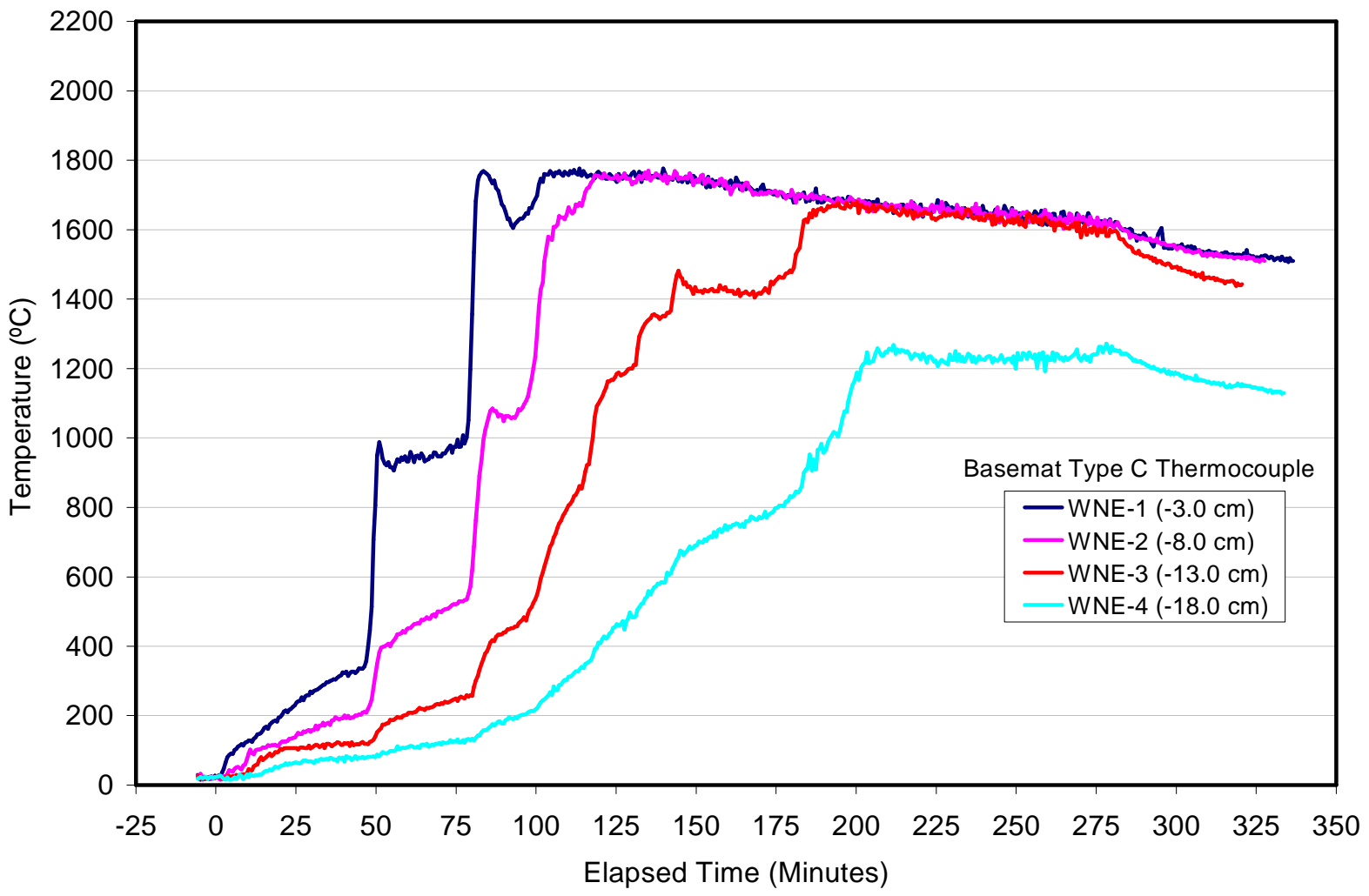

Figure B-4. Basemat Type C "WNE" Array Data. 
OECD/MCCI-2009-TR06 Rev. 1

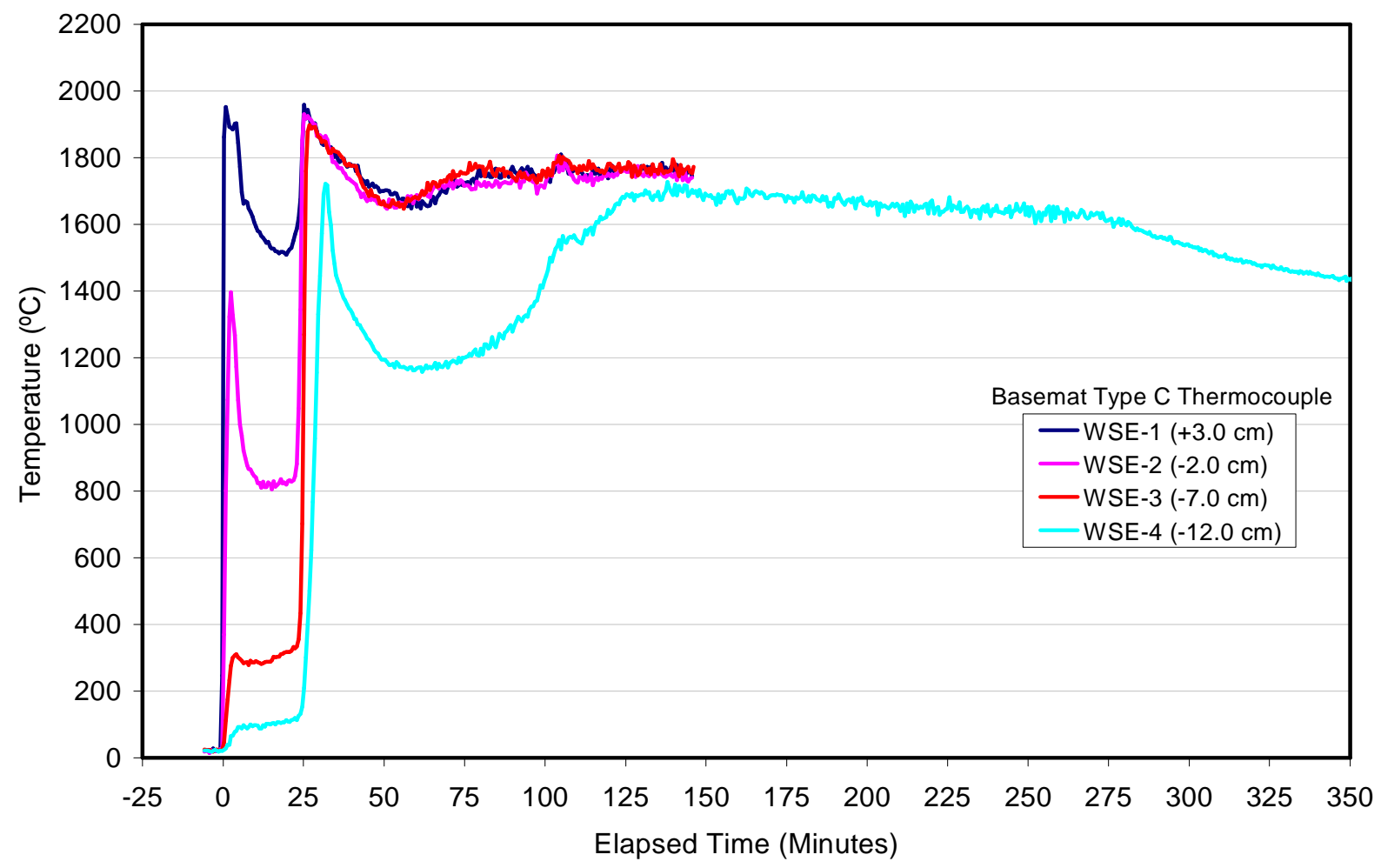

Figure B-5. Basemat Type C "WSE” Array Data.

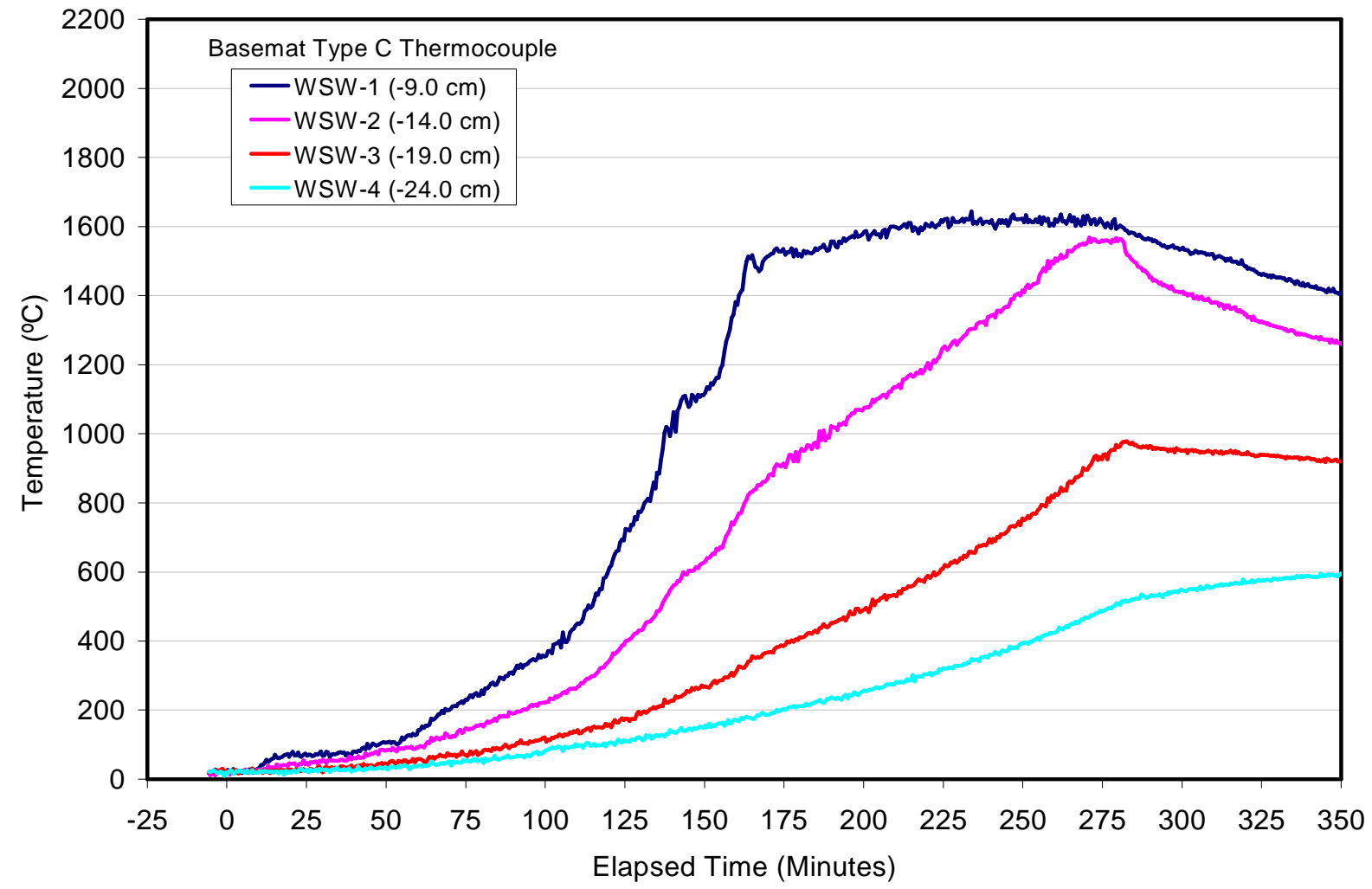

Figure B-6. Basemat Type C "WSW" Array Data. 
OECD/MCCI-2009-TR06 Rev. 1

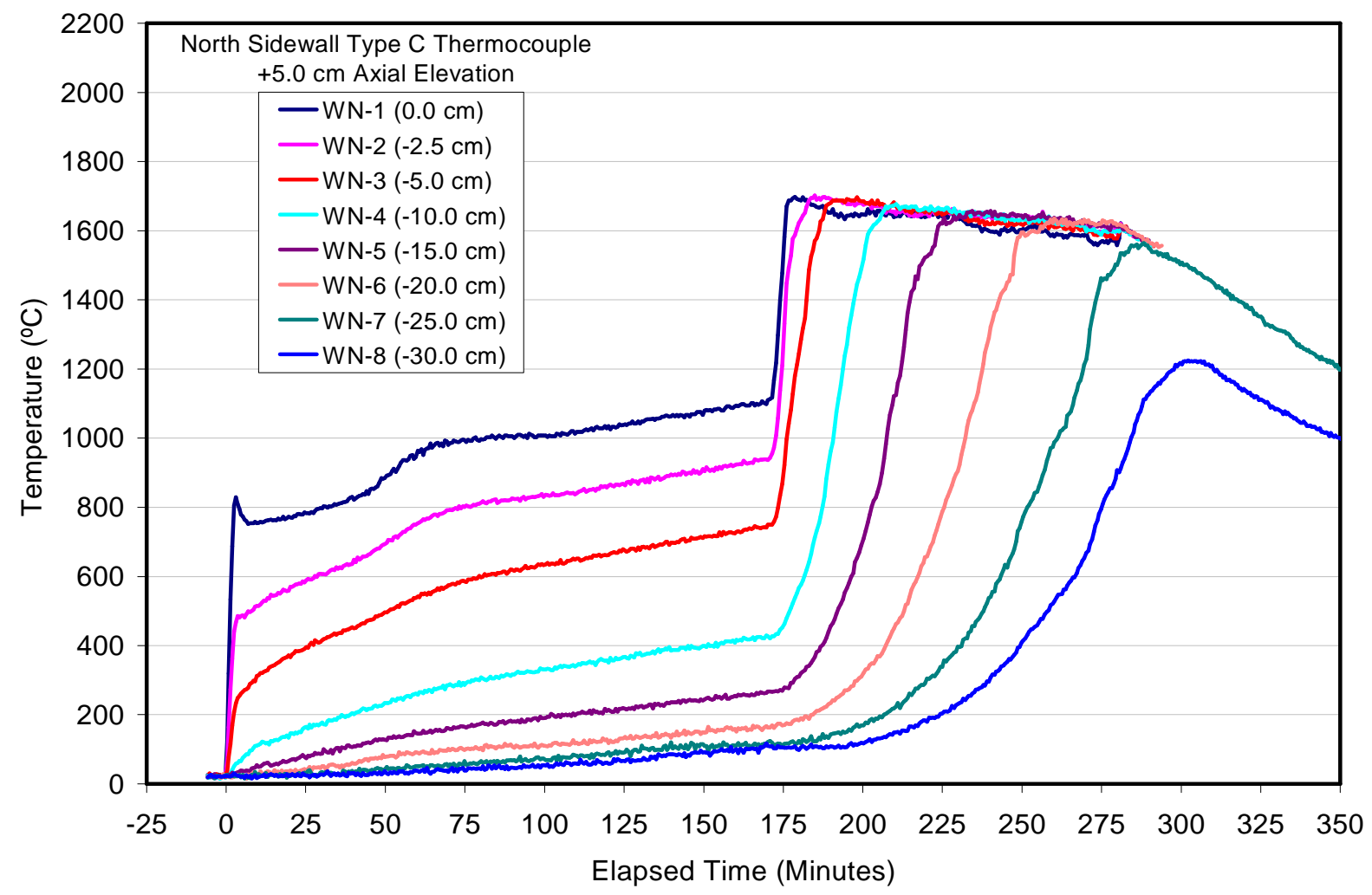

Figure B-7. North Sidewall Type C "WN" Array Data.

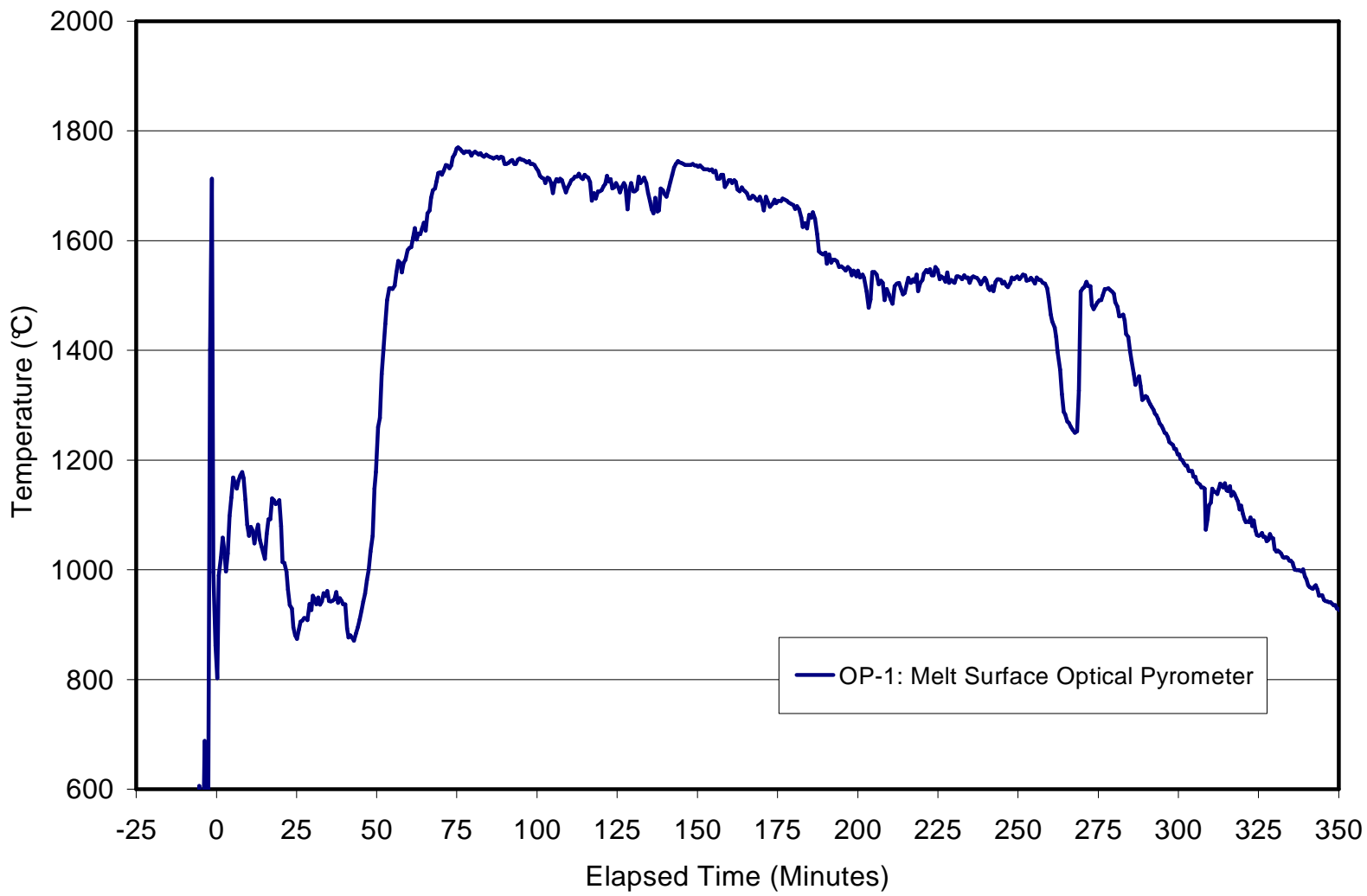

Figure B-8. Melt Surface Temperature Optical Pyrometer OP-1 Data. 
OECD/MCCI-2009-TR06 Rev. 1

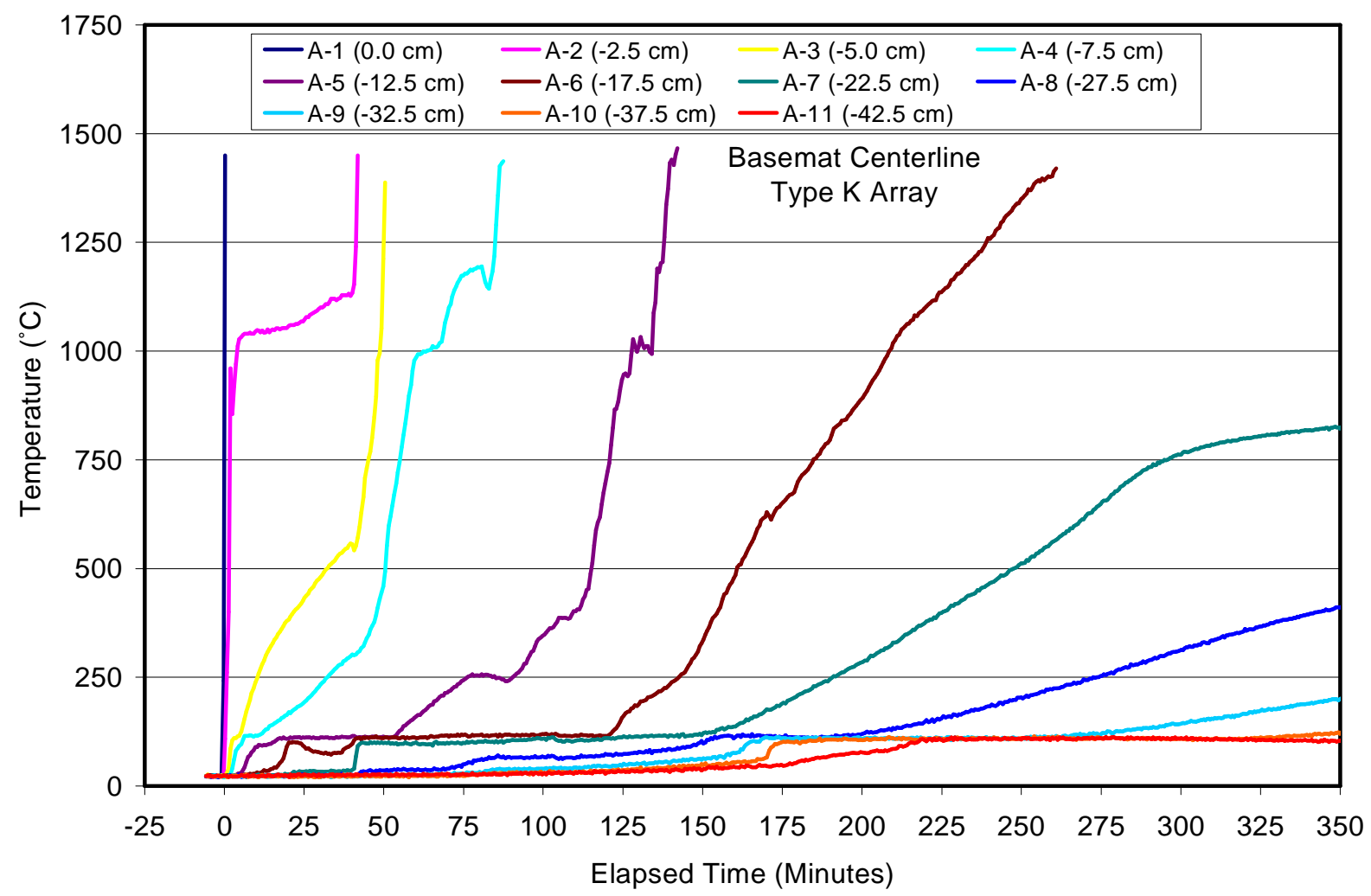

Figure B-9. Basemat Type K "A" Array Data.

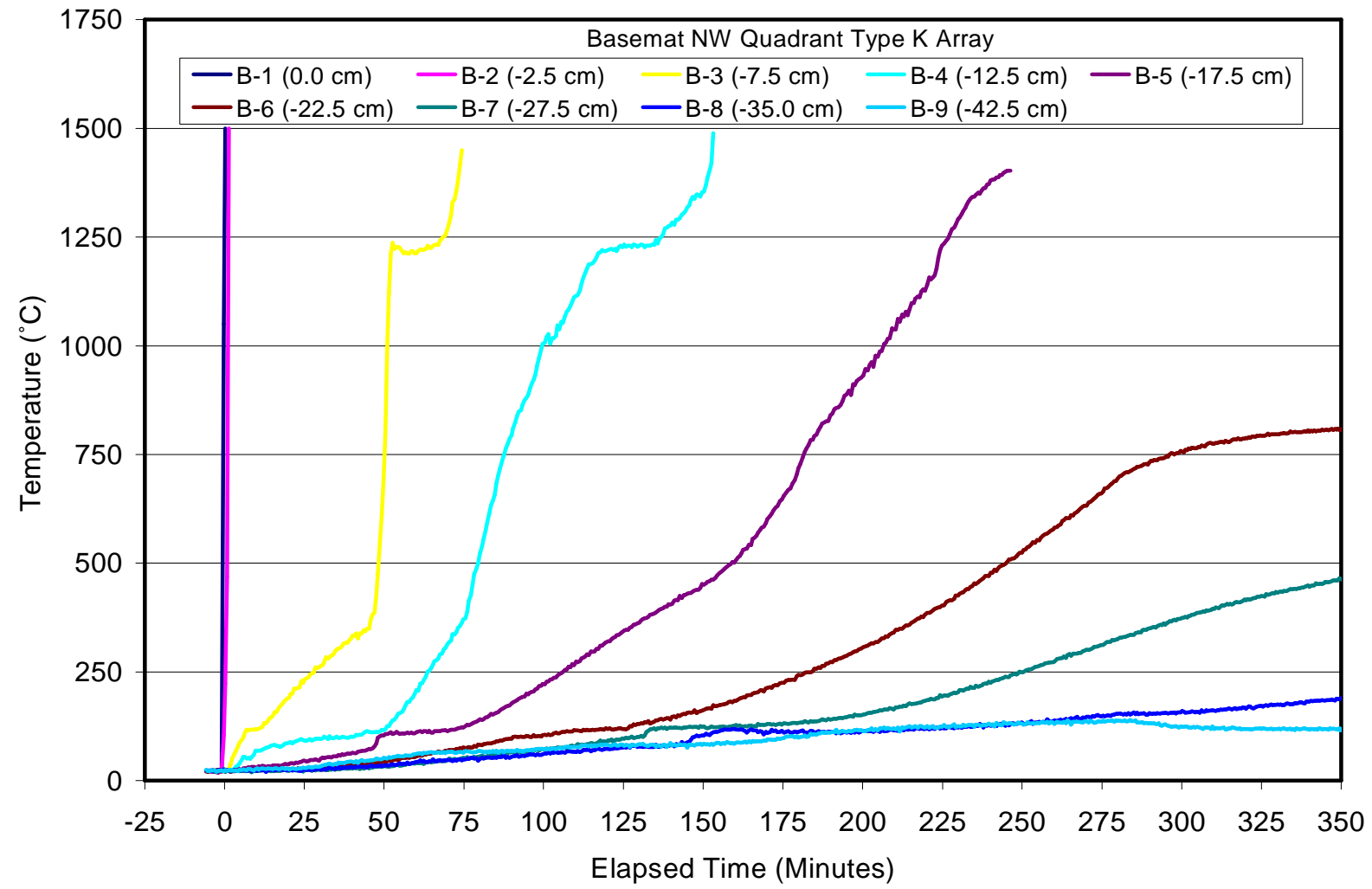

Figure B-10. Basemat Type K “B” Array Data. 
OECD/MCCI-2009-TR06 Rev. 1

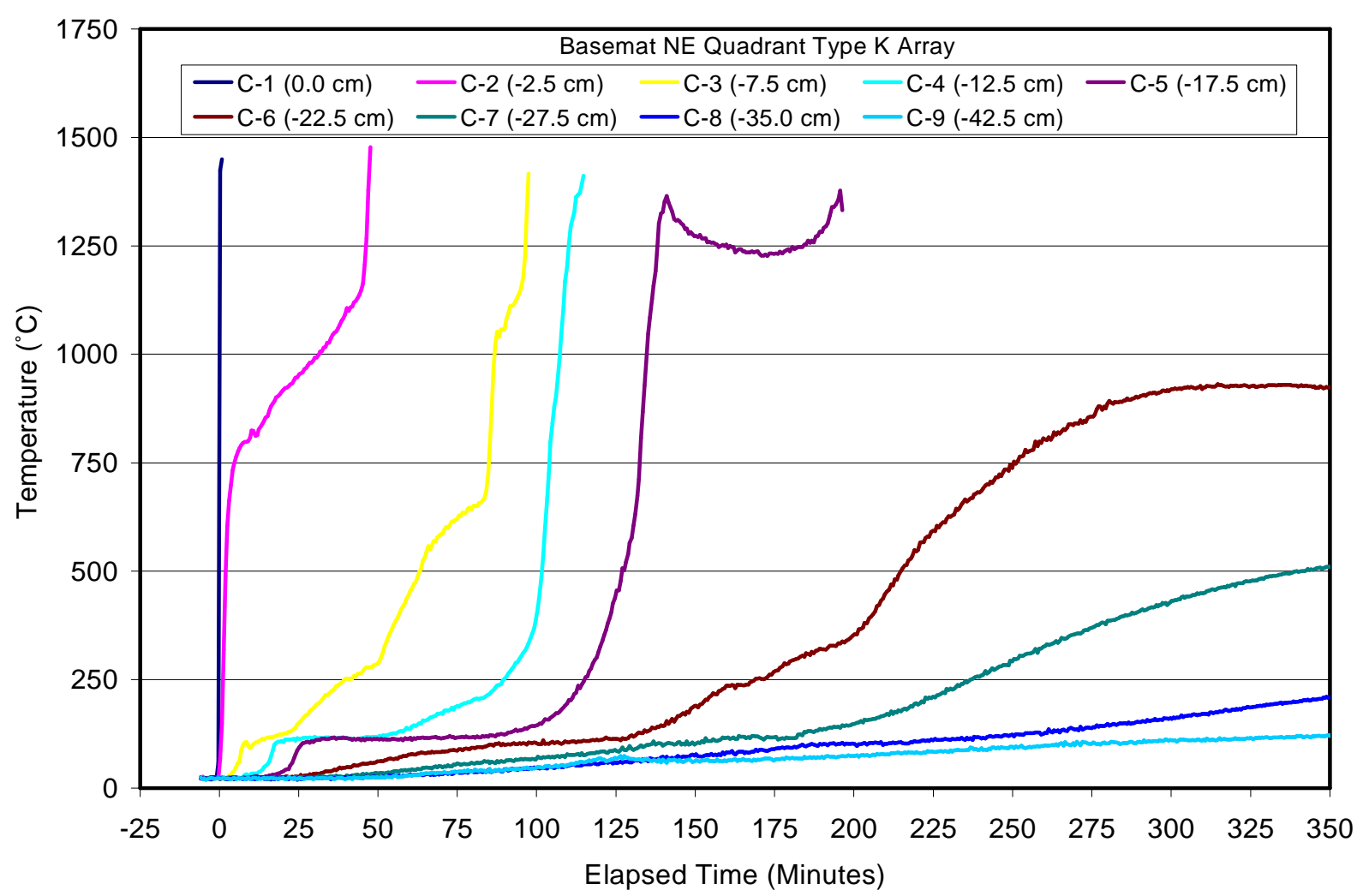

Figure B-11. Basemat Type K “C” Array Data.

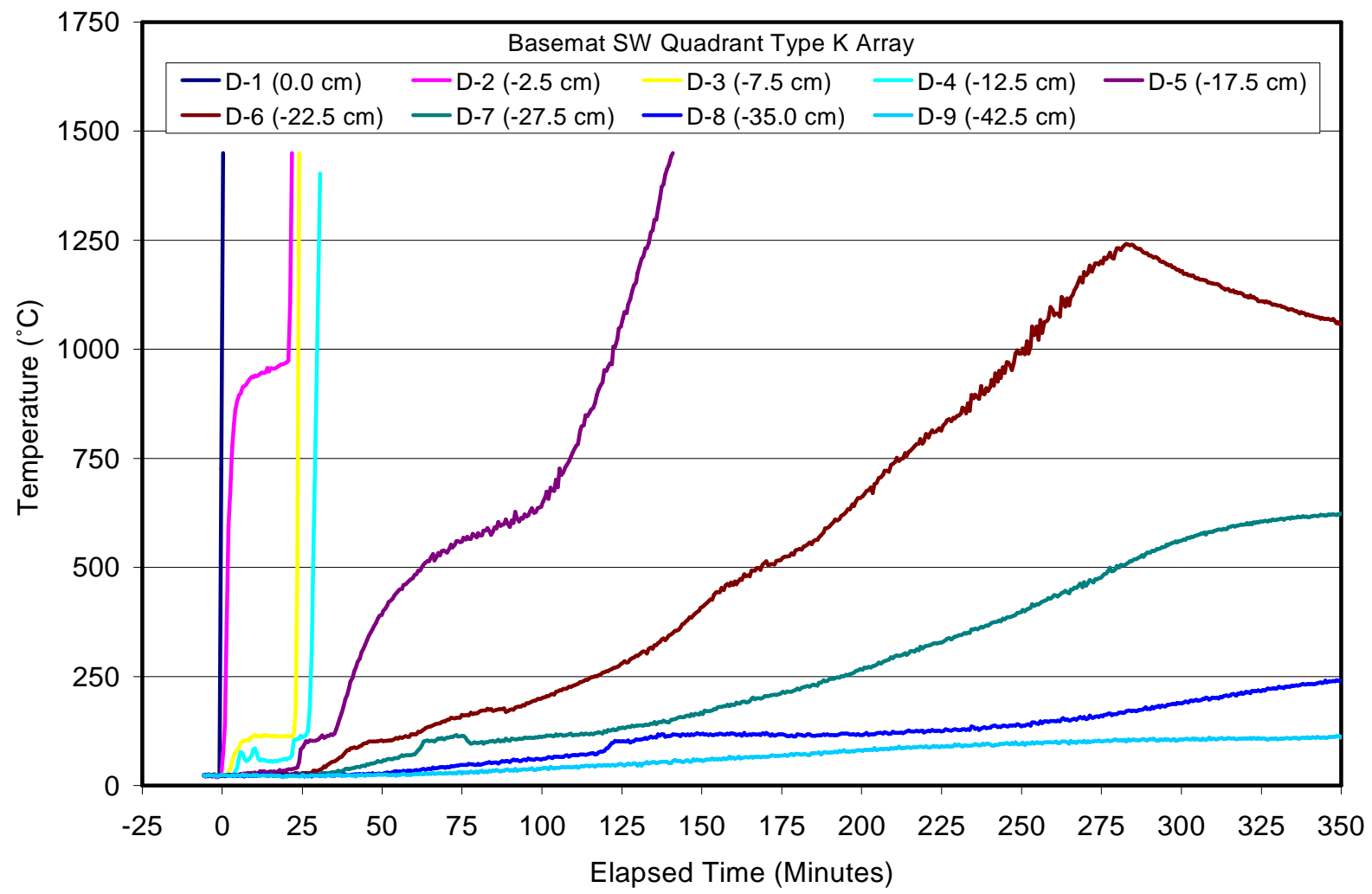

Figure B-12. Basemat Type K “D” Array Data. 
OECD/MCCI-2009-TR06 Rev. 1

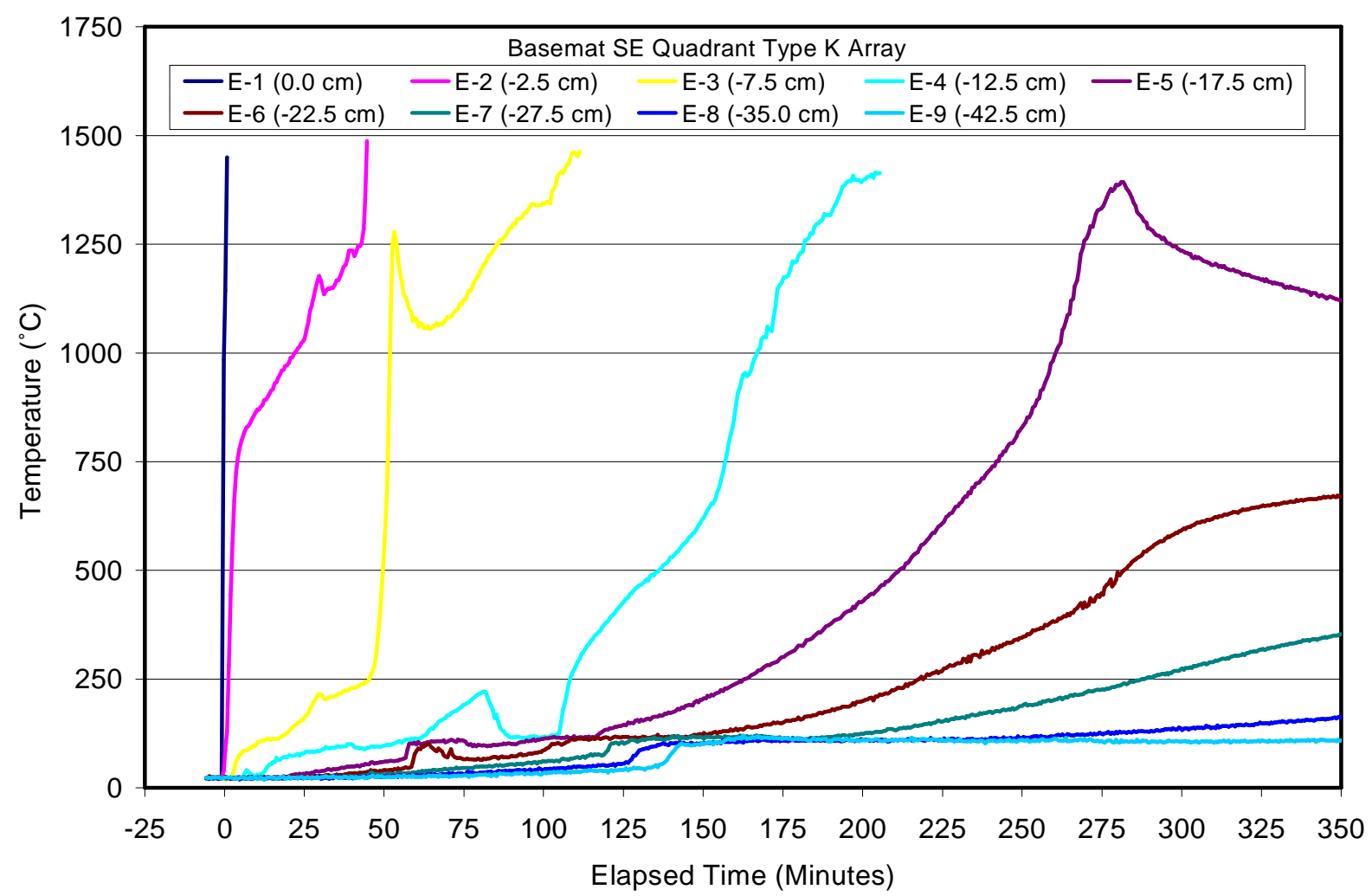

Figure B-13. Basemat Type K “E” Array Data.

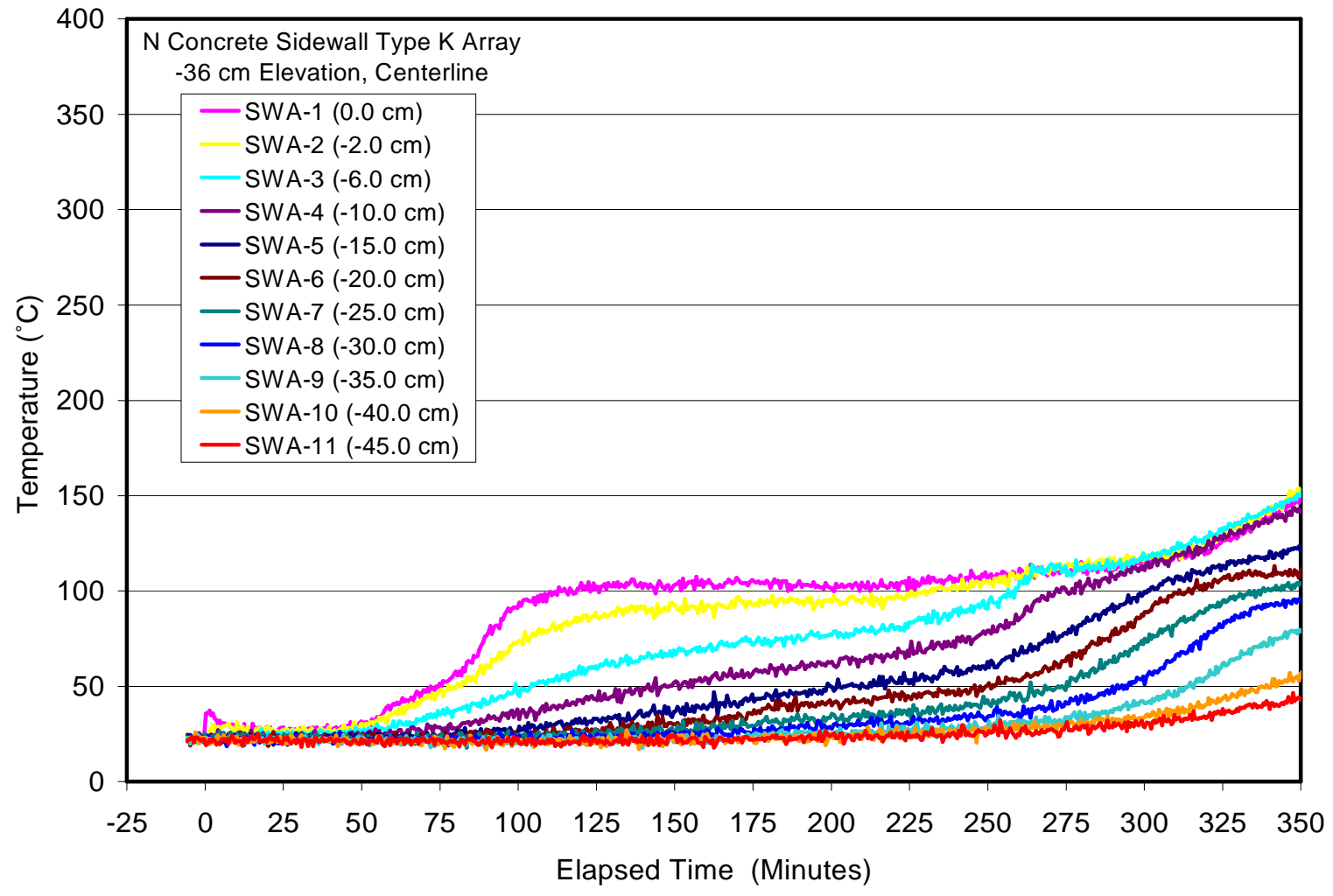

Figure B-14. North Sidewall Type K "SWA" Array Data. 
OECD/MCCI-2009-TR06 Rev. 1

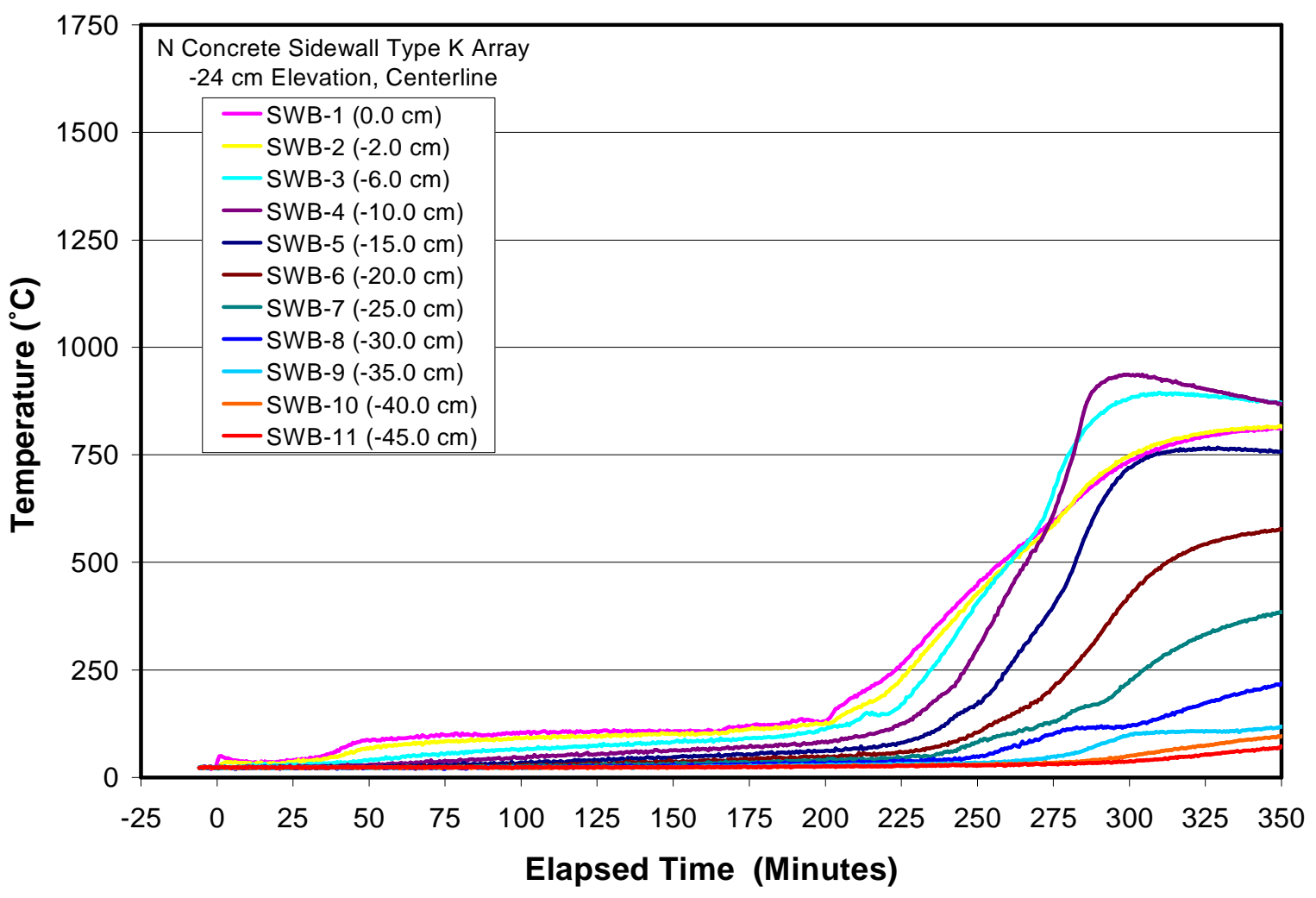

Figure B-15. North Sidewall Type K "SWB" Array Data.

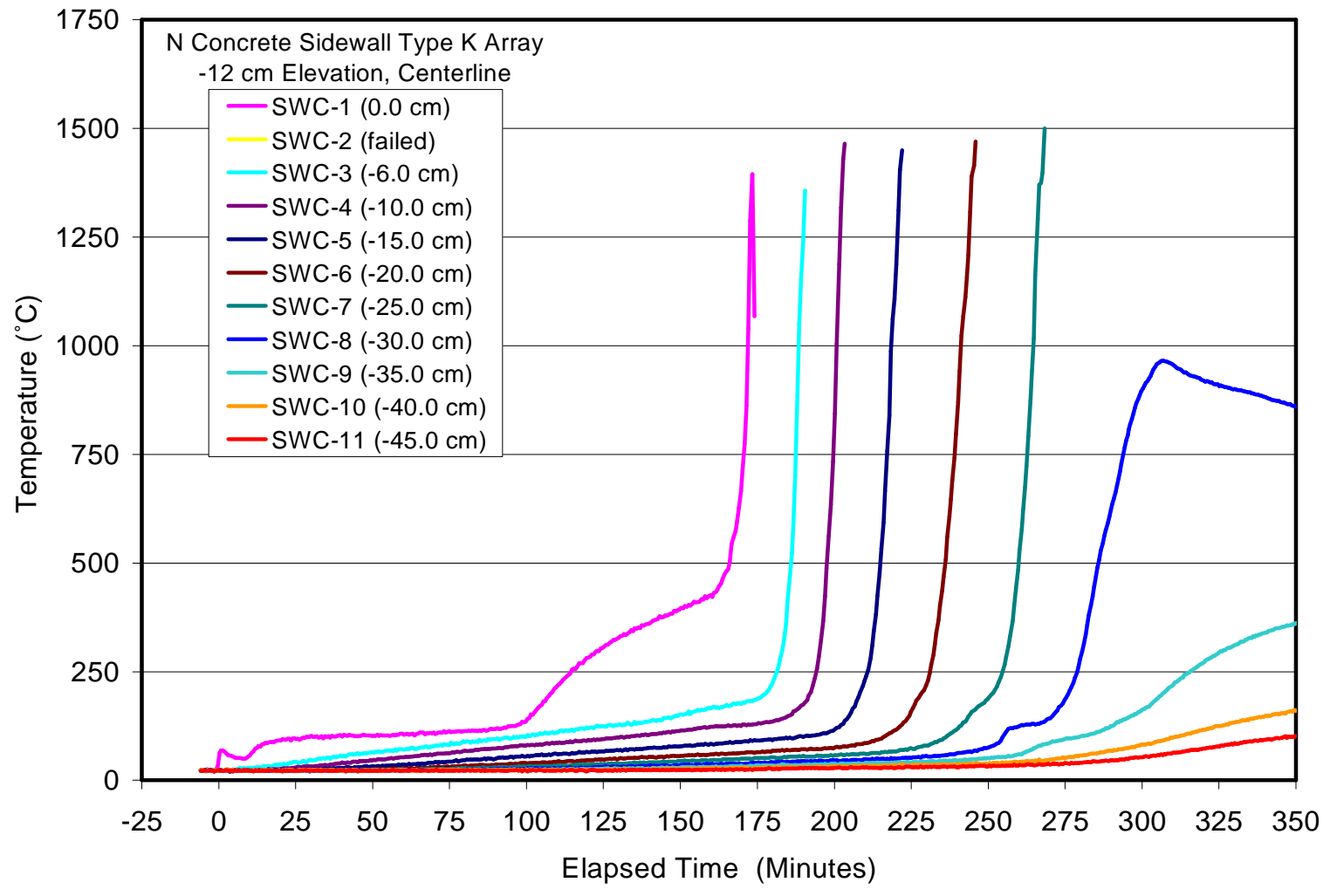

Figure B-16. North Sidewall Type K "SWC" Array Data. 
OECD/MCCI-2009-TR06 Rev. 1

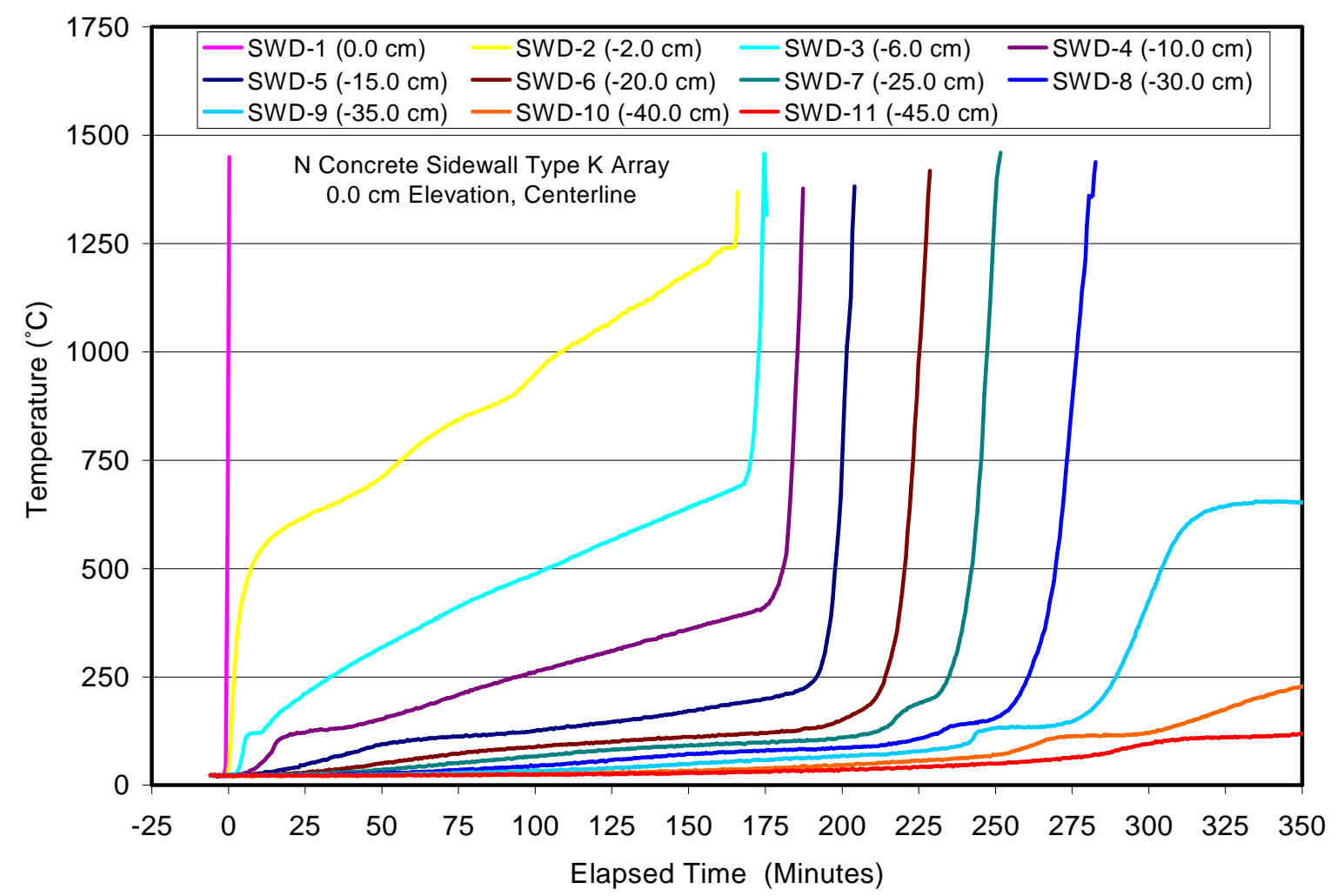

Figure B-17. North Sidewall Type K “SWD” Array Data.

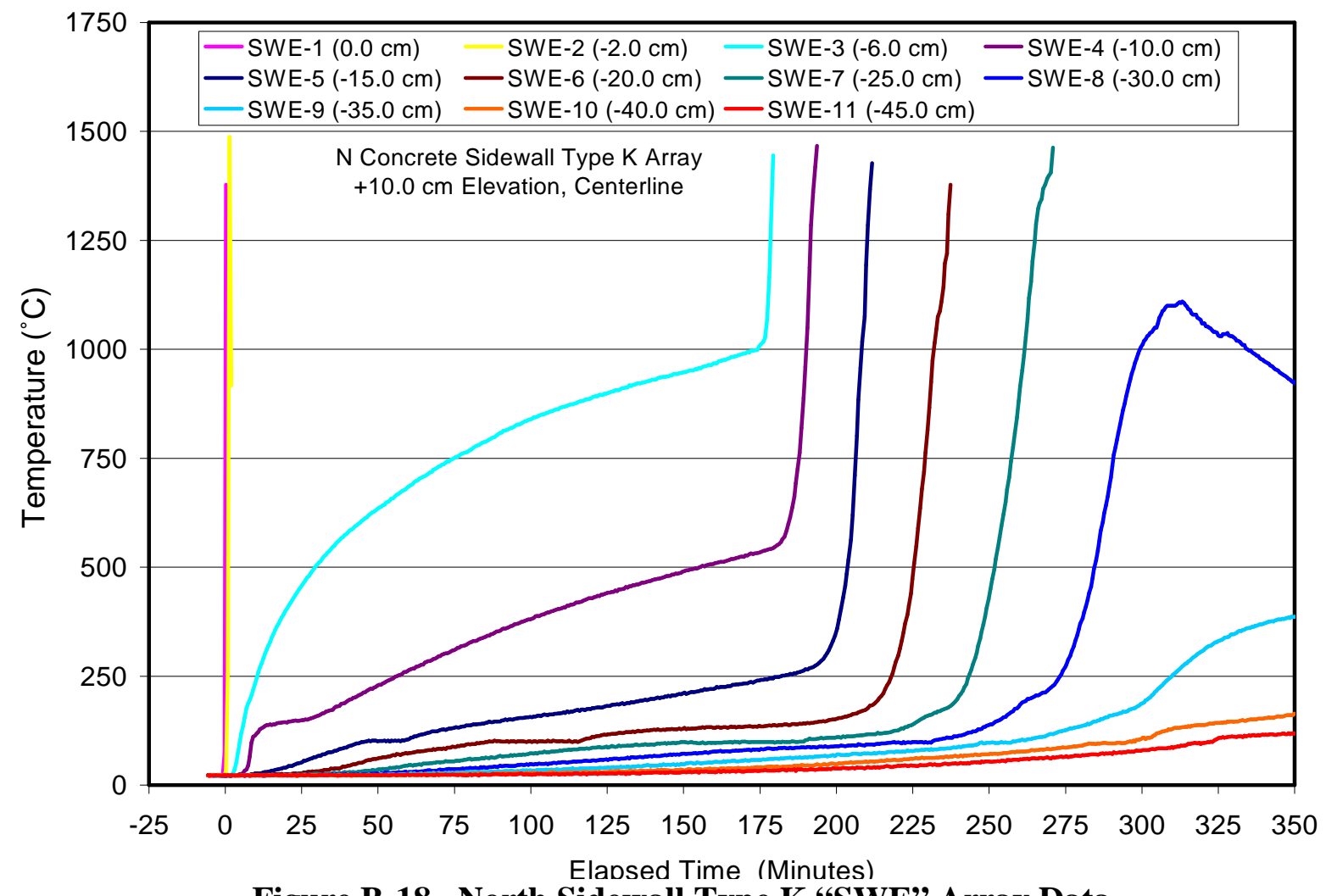

Figure B-18. North Sidewall Type K “SWE” Array Data. 
OECD/MCCI-2009-TR06 Rev. 1

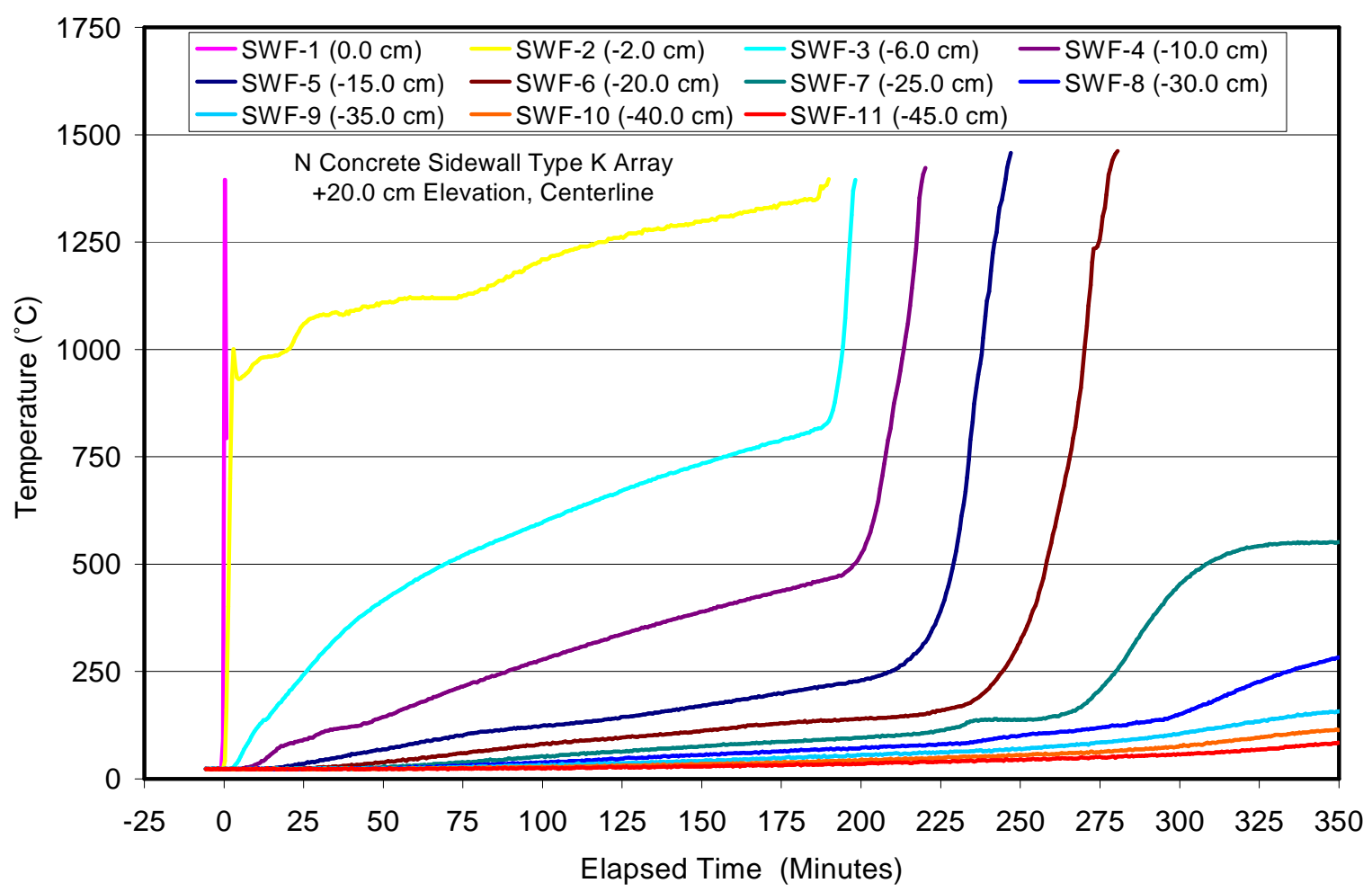

Figure B-19. North Sidewall Type K “SWF" Array Data.

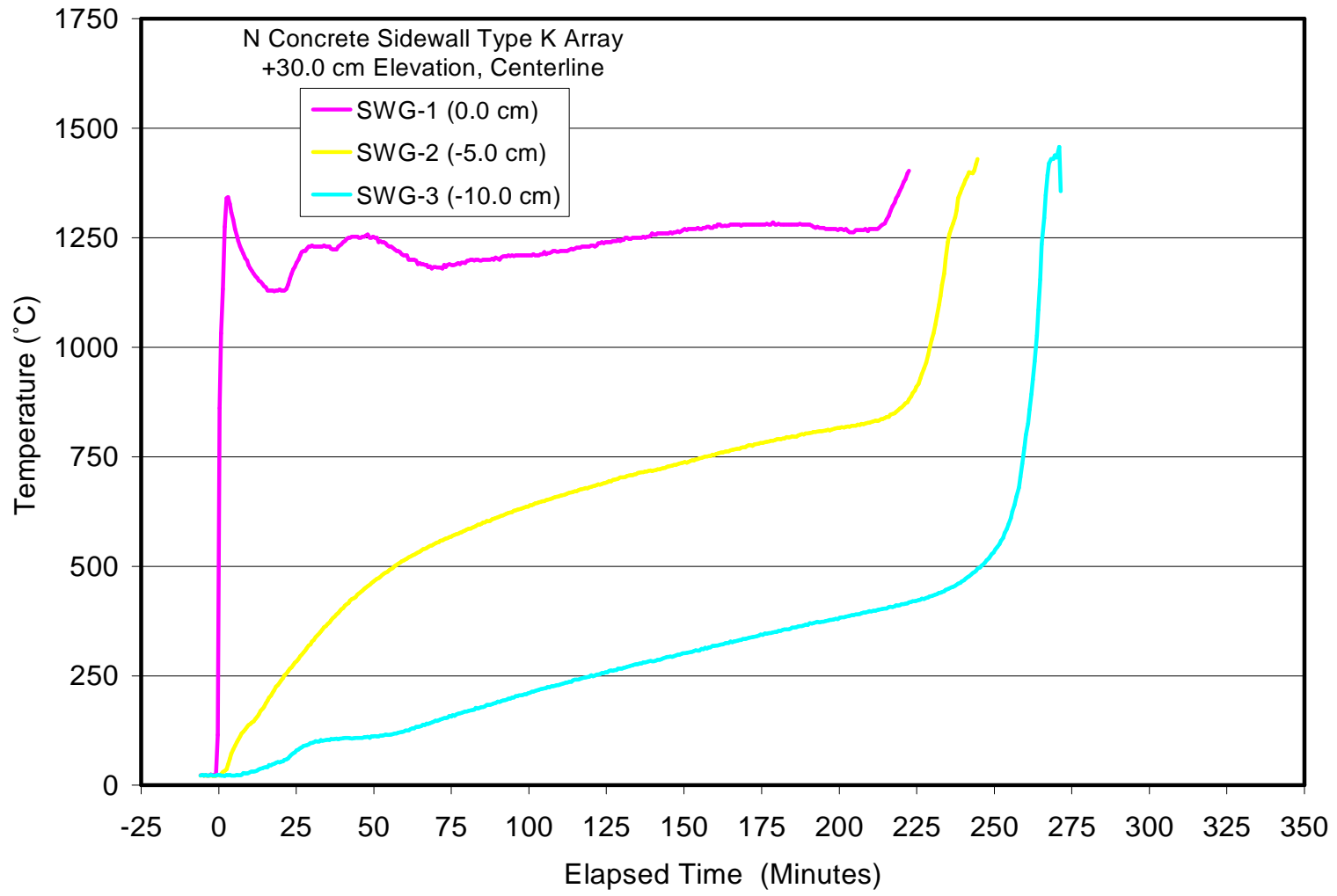

Figure B-20. North Sidewall Type K 'SWG" Array Data. 
OECD/MCCI-2009-TR06 Rev. 1

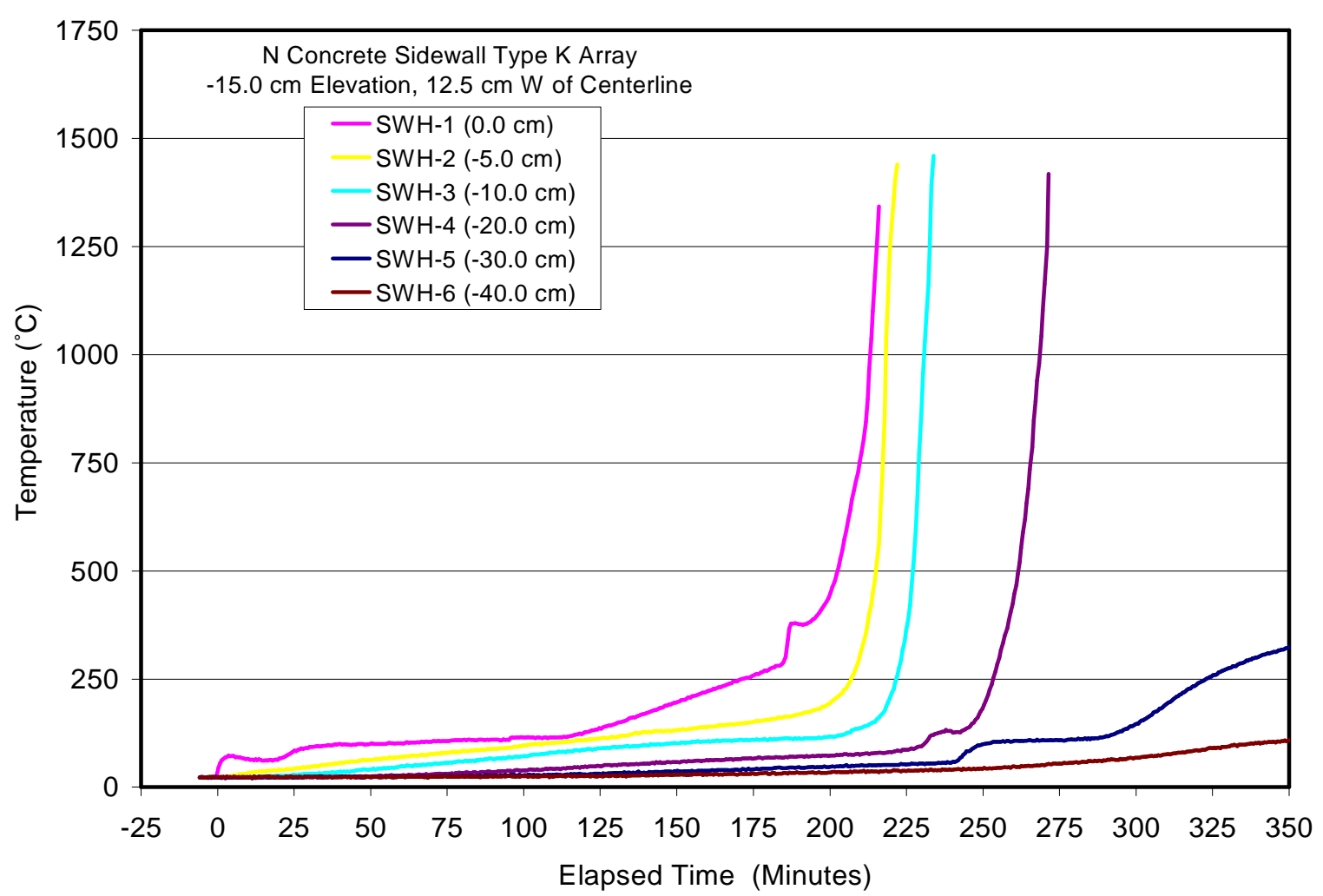

Figure B-21. North Sidewall Type K “SWH” Array Data.

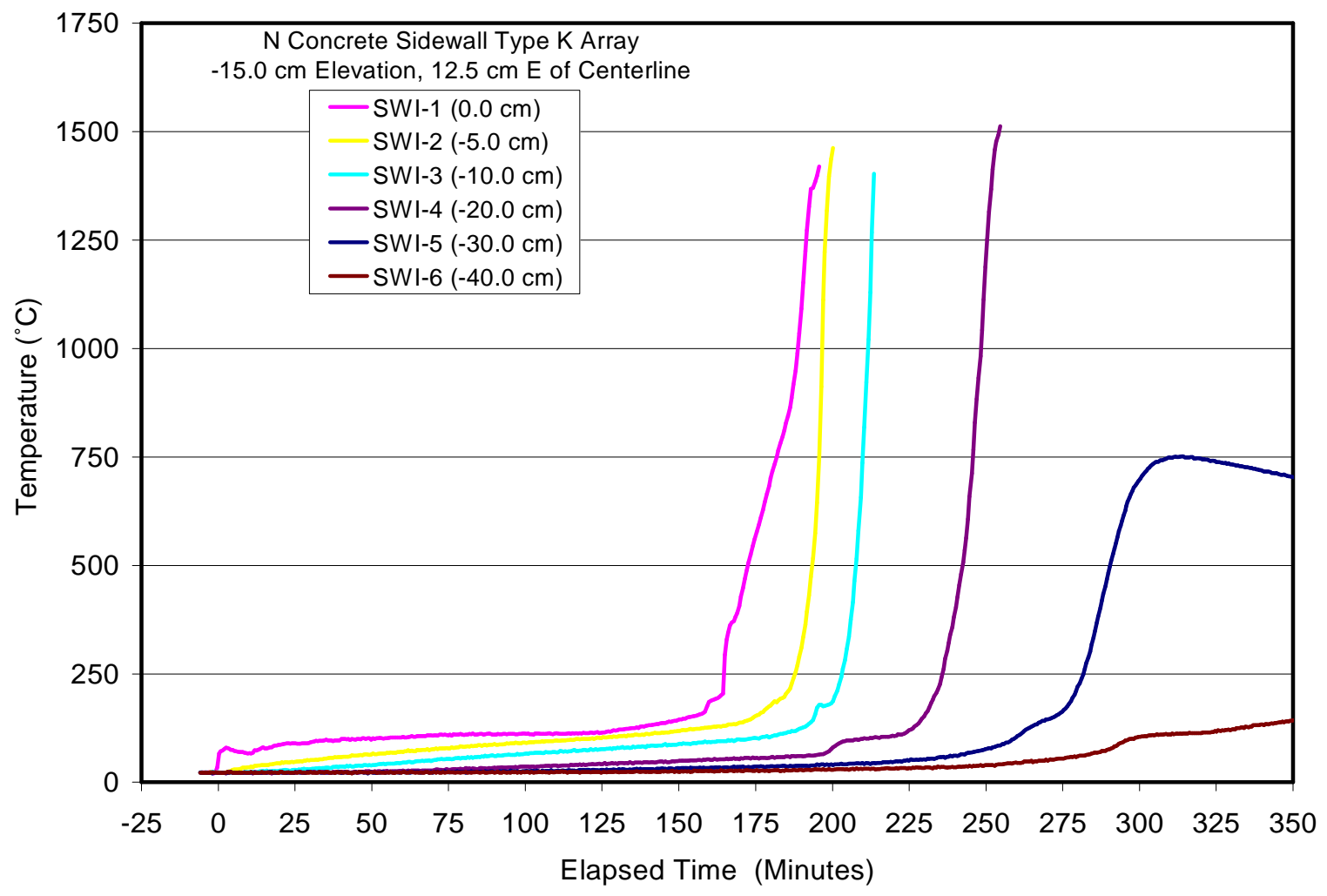

Figure B-22. North Sidewall Type K "SWI" Array Data. 
OECD/MCCI-2009-TR06 Rev. 1

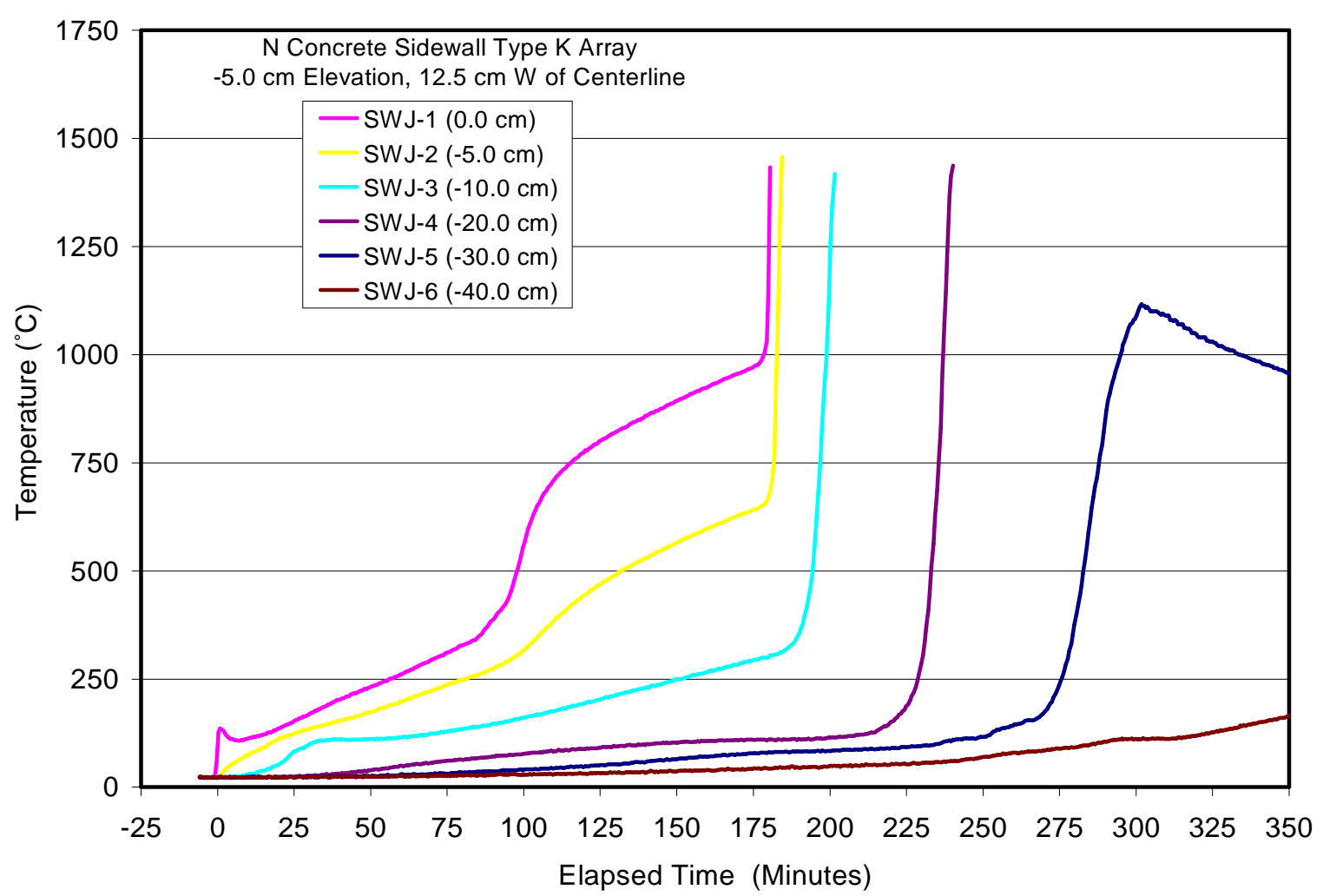

Figure B-23. North Sidewall Type K “SWJ” Array Data.

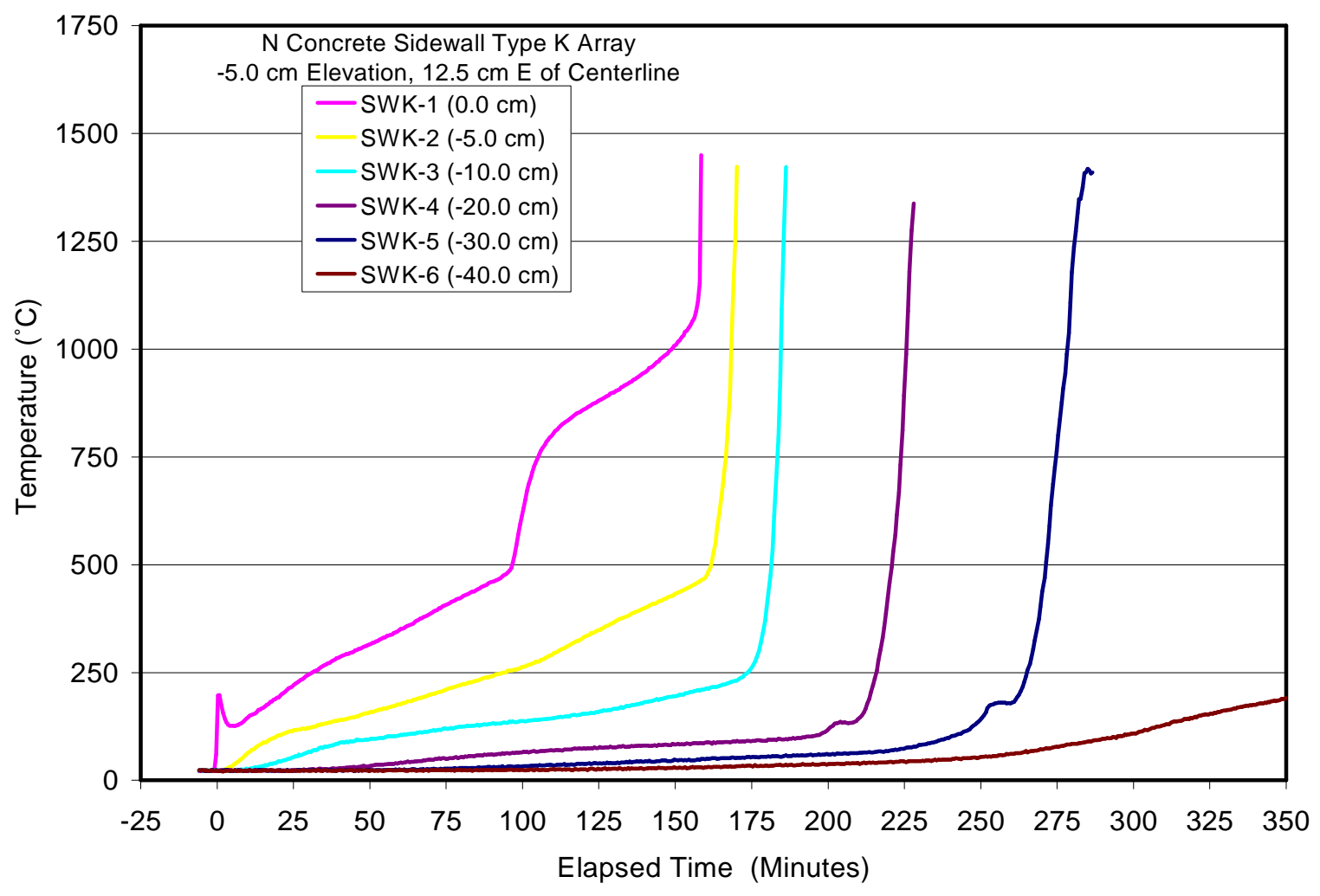

Figure B-24. North Sidewall Type K "SWK” Array Data. 
OECD/MCCI-2009-TR06 Rev. 1

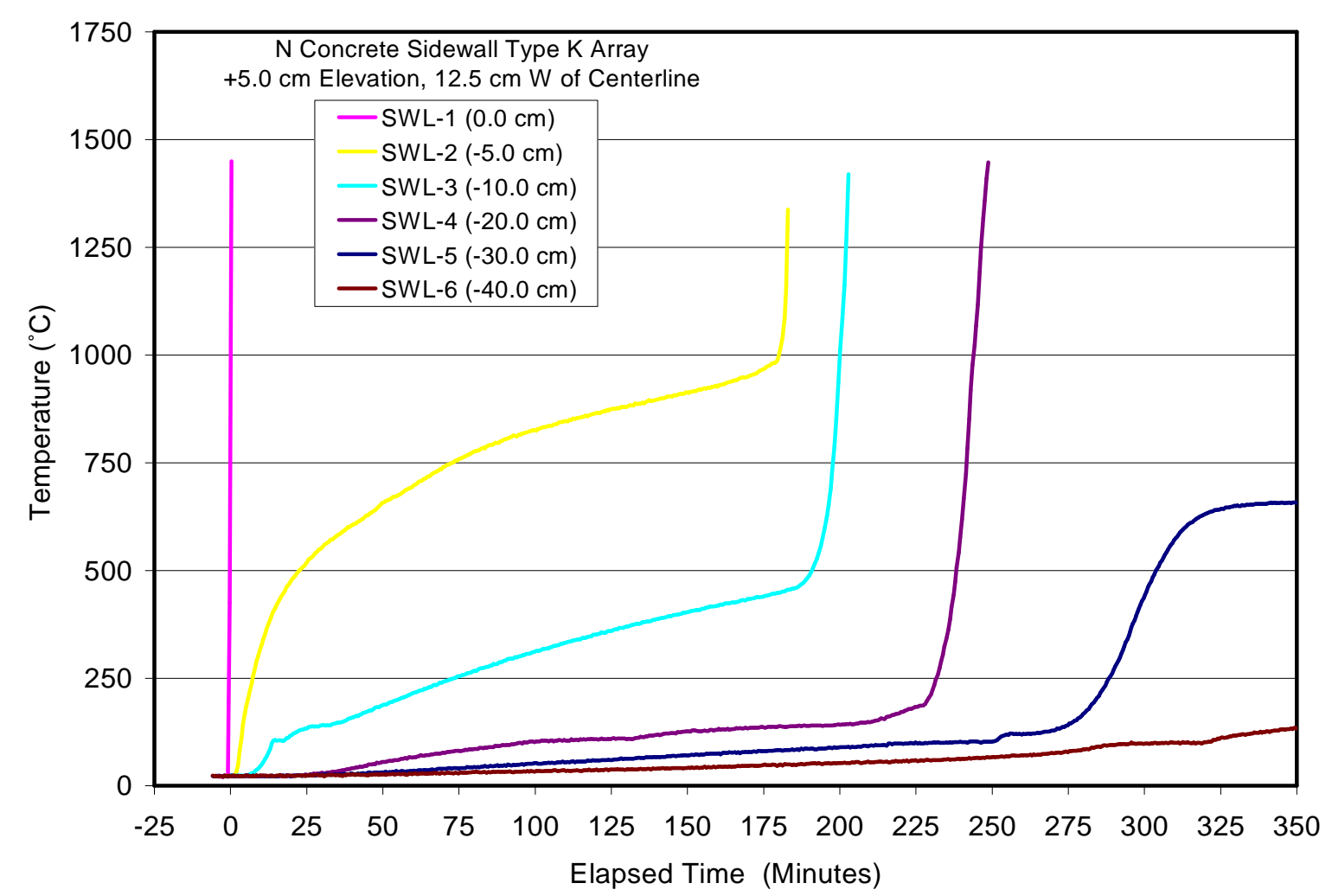

Figure B-25. North Sidewall Type K "SWL" Array Data.

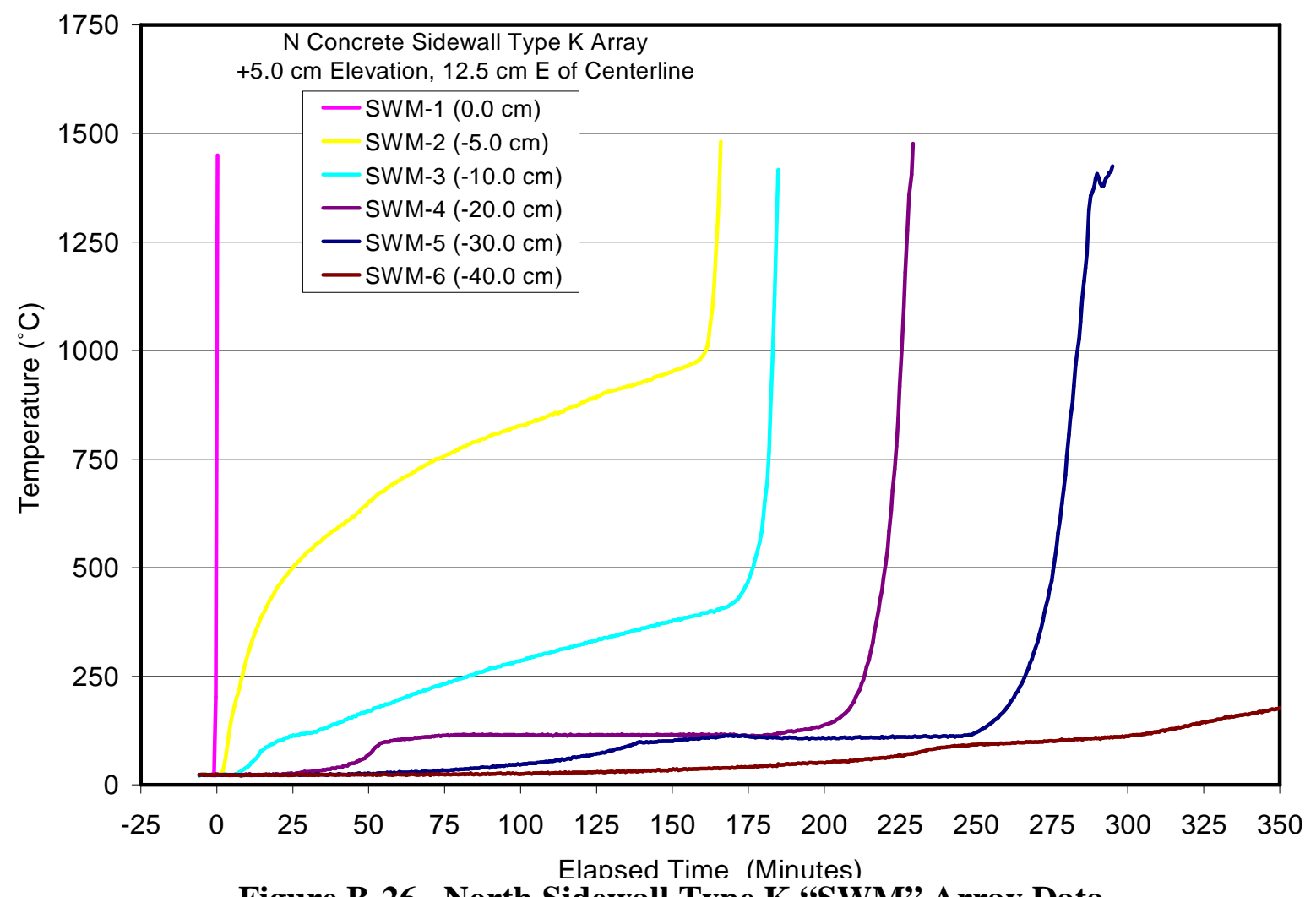

Figure B-26. North Sidewall Type K “SWM” Array Data. 
OECD/MCCI-2009-TR06 Rev. 1

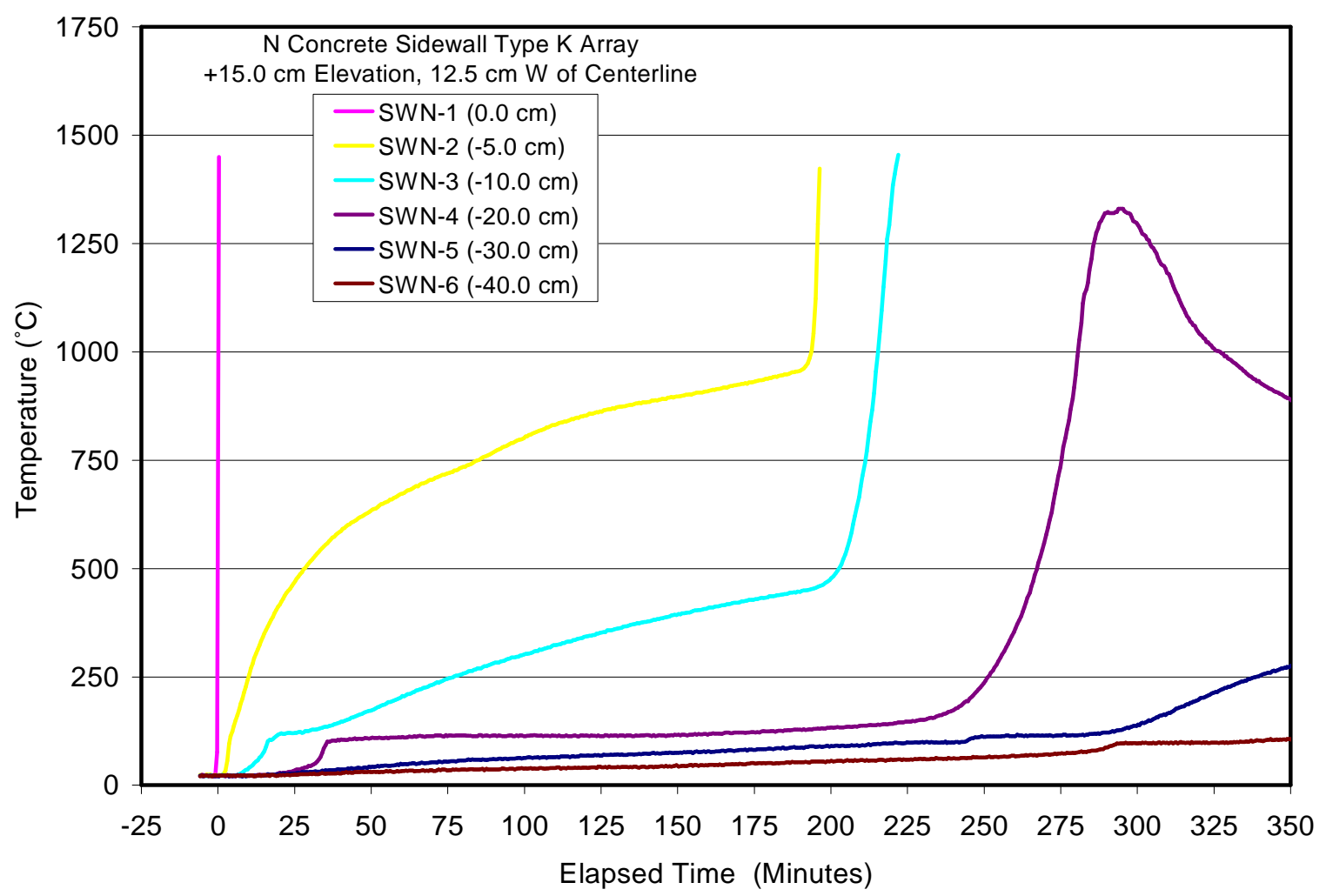

Figure B-27. North Sidewall Type K "SWN" Array Data.

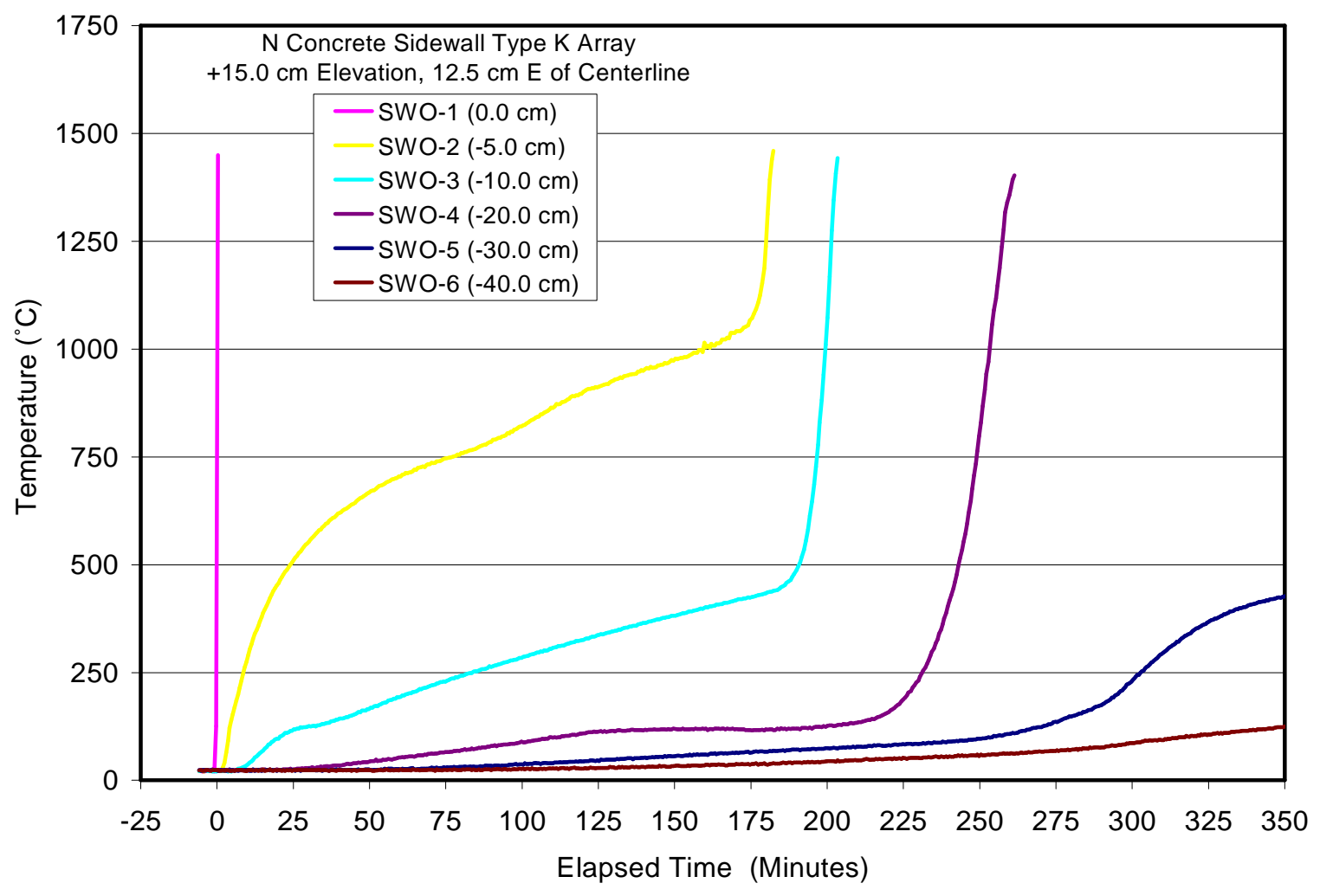

Figure B-28. North Sidewall Type K “SWO” Array Data. 
OECD/MCCI-2009-TR06 Rev. 1

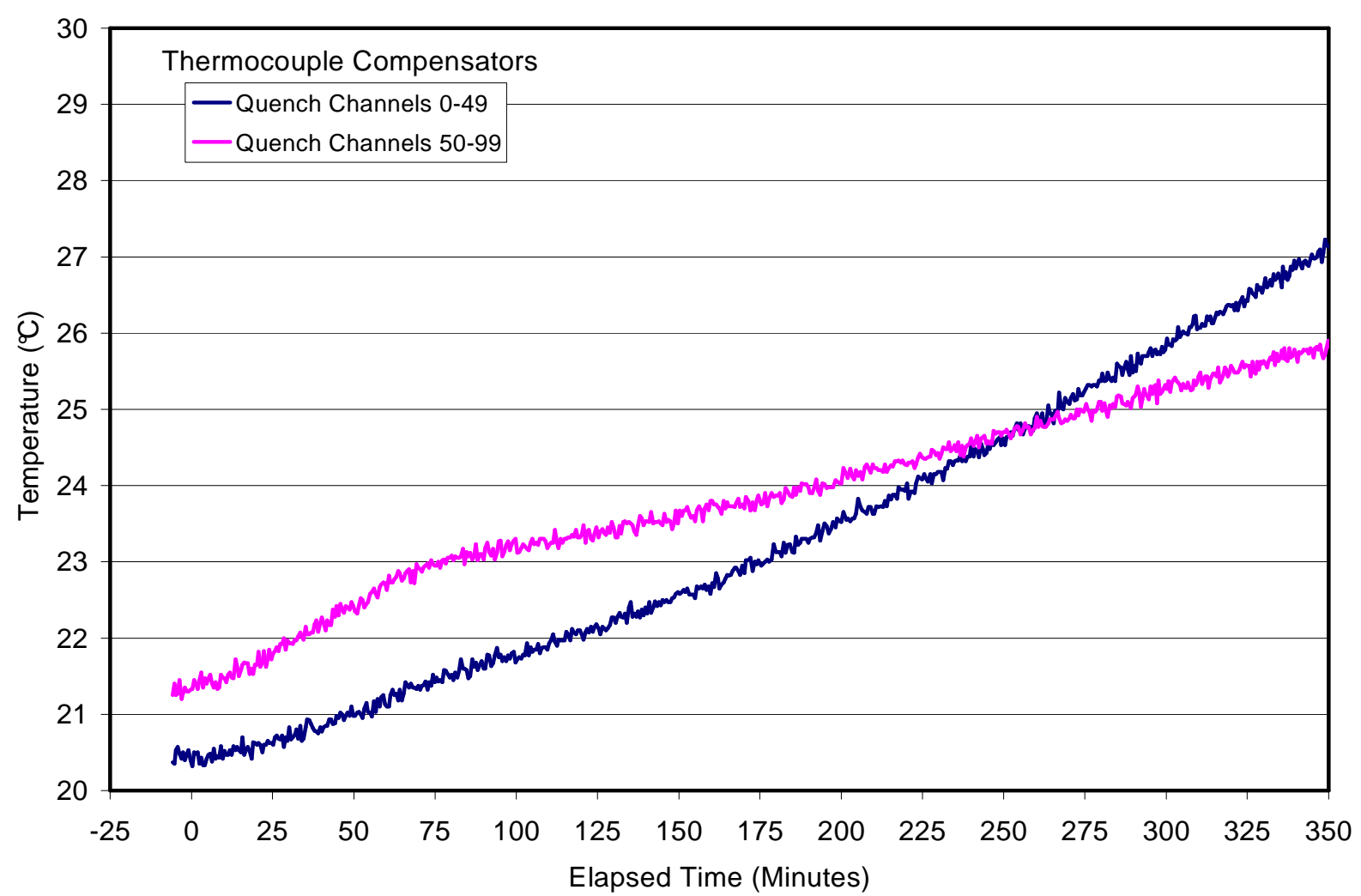

Figure B-29. Thermocouple Compensator Data for Channels Q0-Q49 and Q50-Q99.

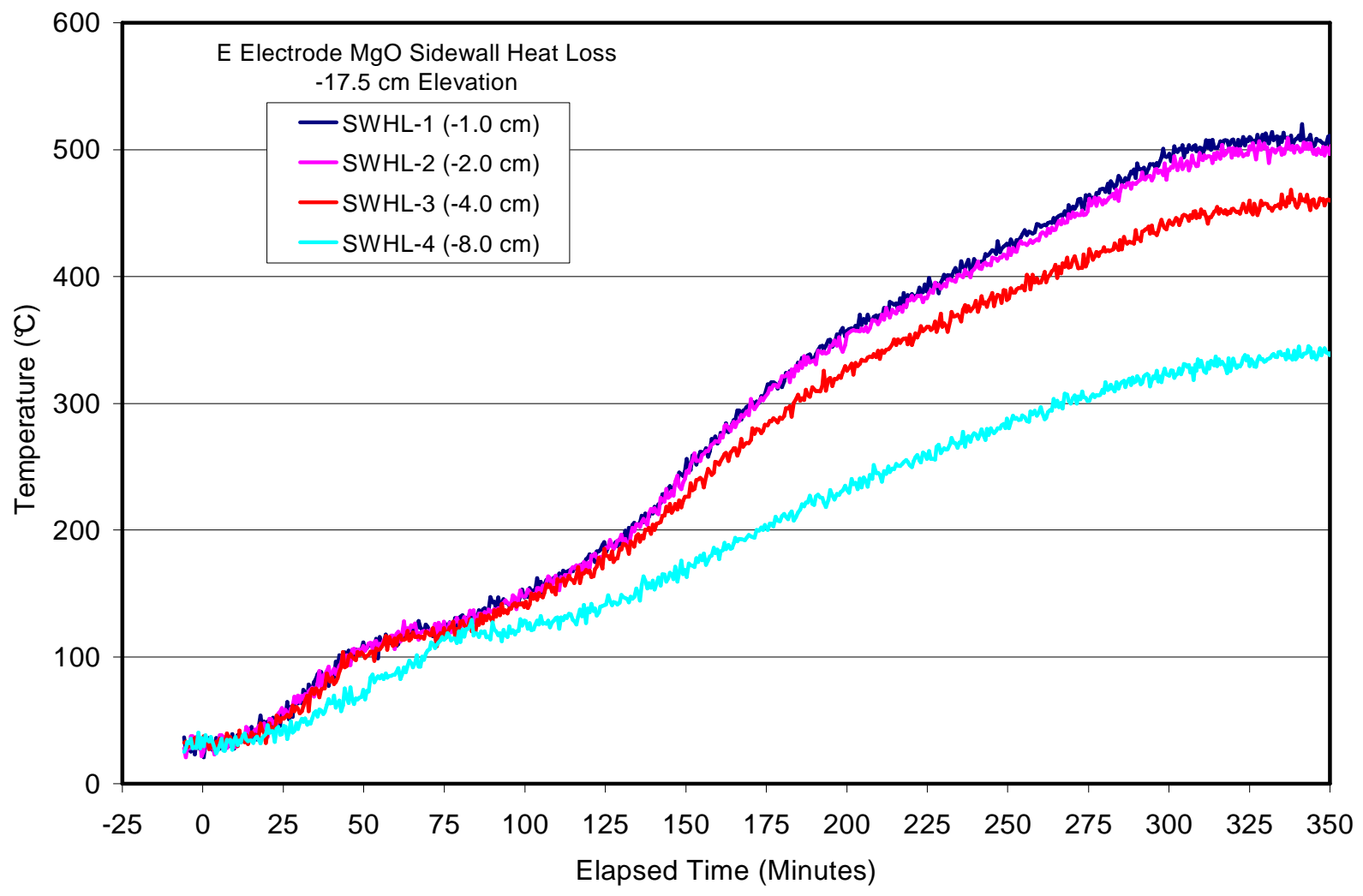

Figure B-30. Test Section Sidewall Heat Loss Data at $\mathbf{- 1 7 . 5} \mathrm{cm}$ Elevation. 
OECD/MCCI-2009-TR06 Rev. 1

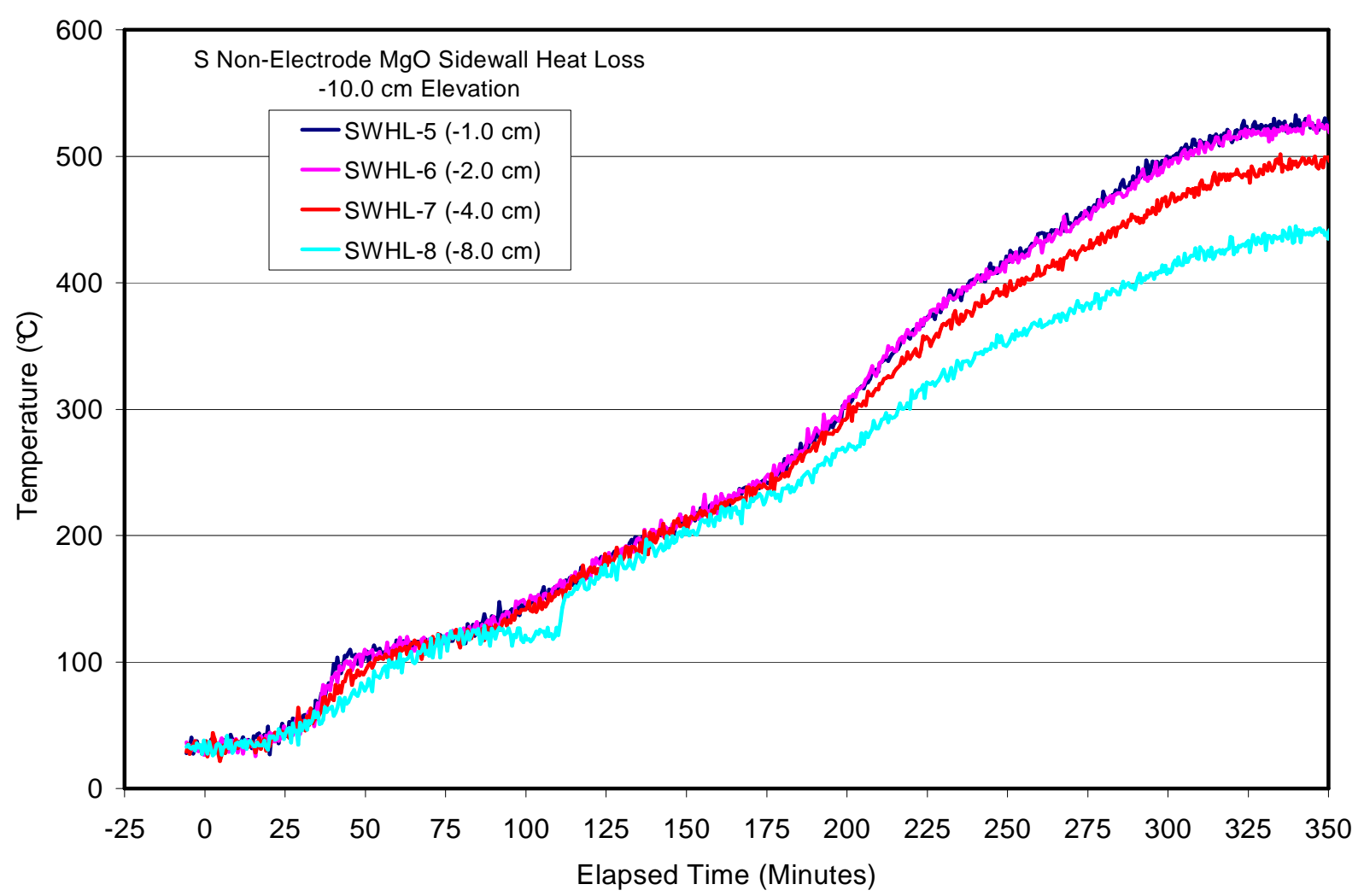

Figure B-31. Test Section Sidewall Heat Loss Data at $\mathbf{- 1 0 . 0} \mathrm{cm}$ Elevation.

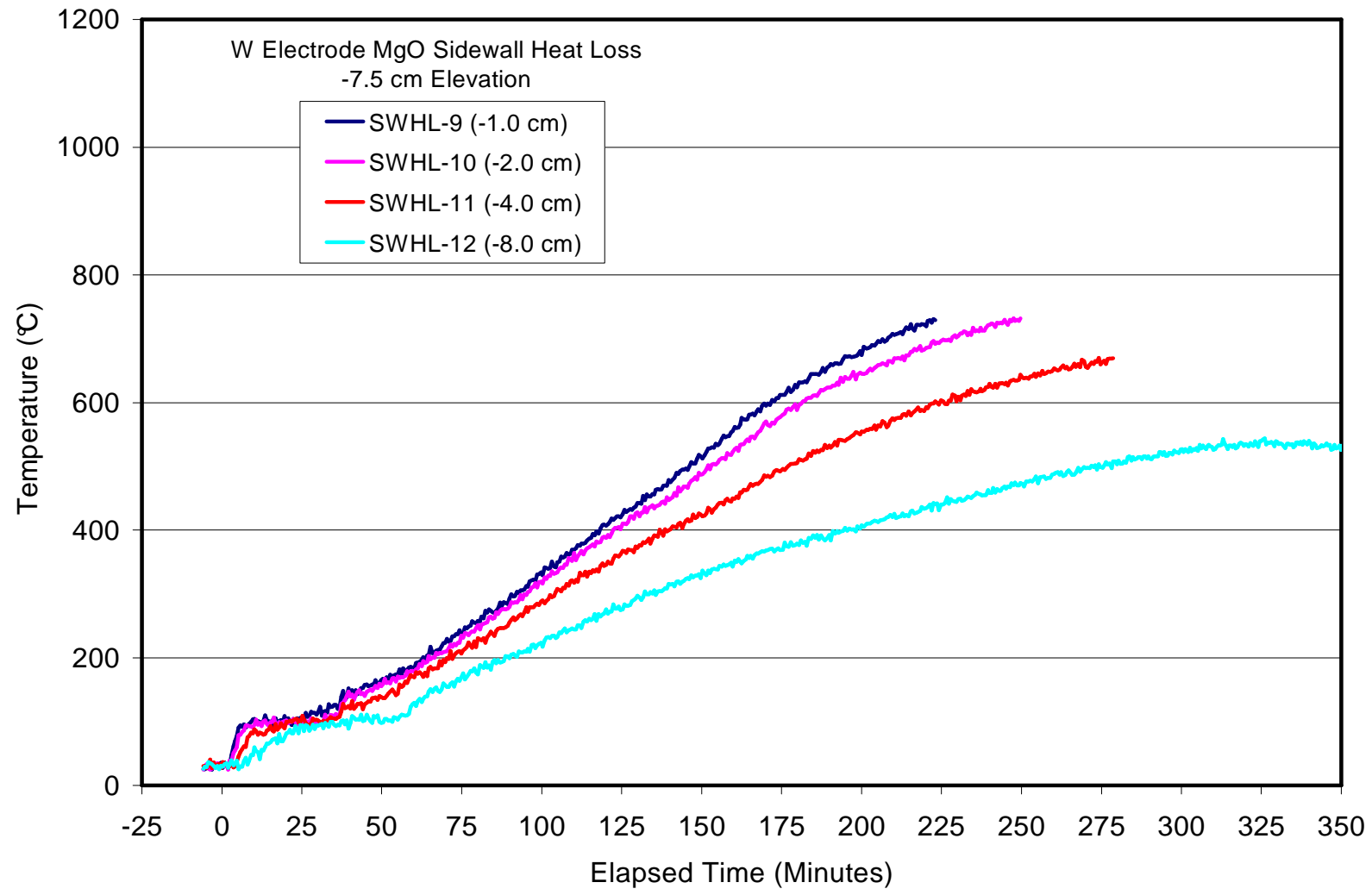

Figure B-32. Test Section Sidewall Heat Loss Data at $\mathbf{- 7 . 5} \mathrm{cm}$ Elevation. 
OECD/MCCI-2009-TR06 Rev. 1

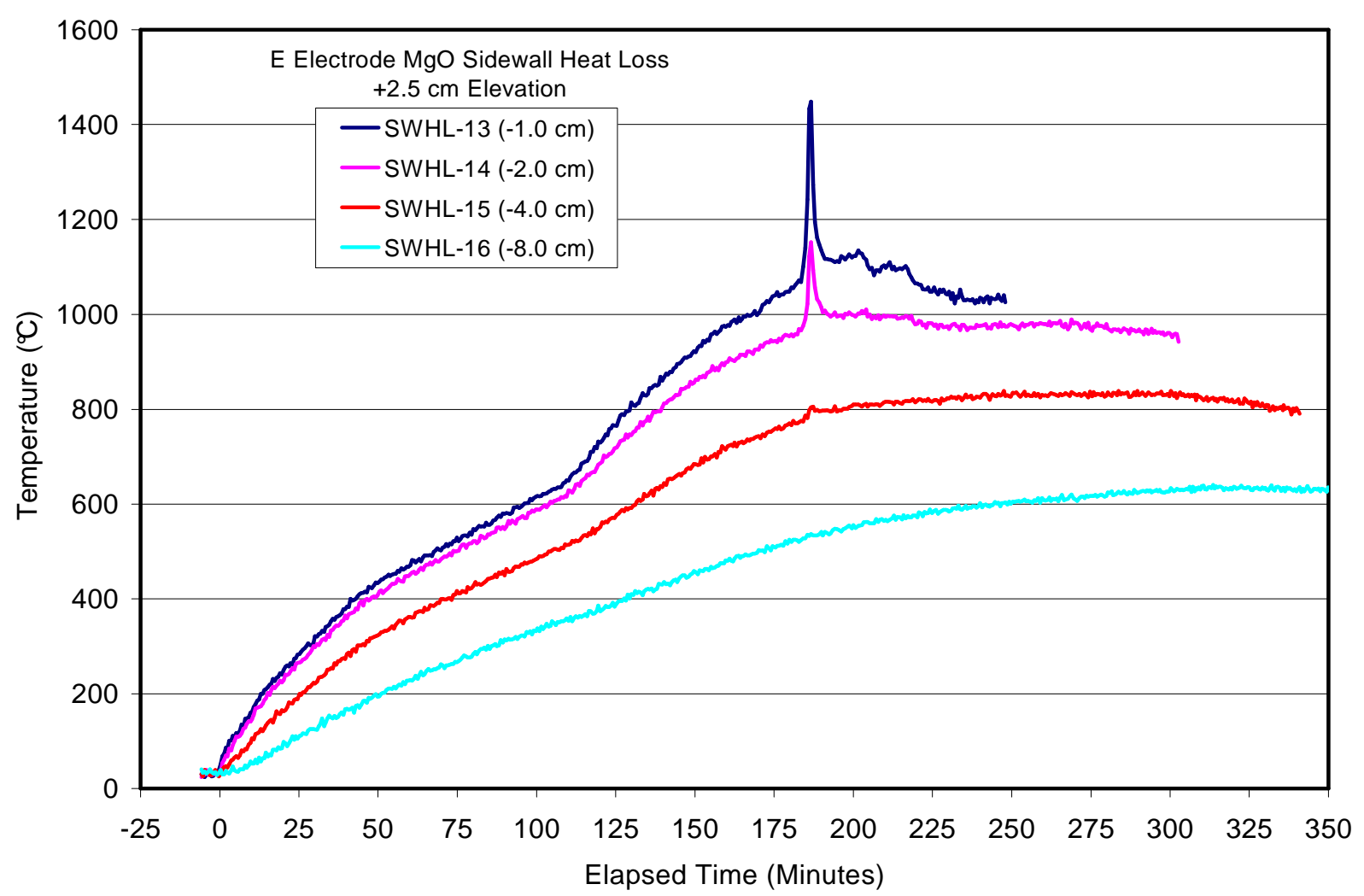

Figure B-33. Test Section Sidewall Heat Loss Data at $+2.5 \mathrm{~cm}$ Elevation.

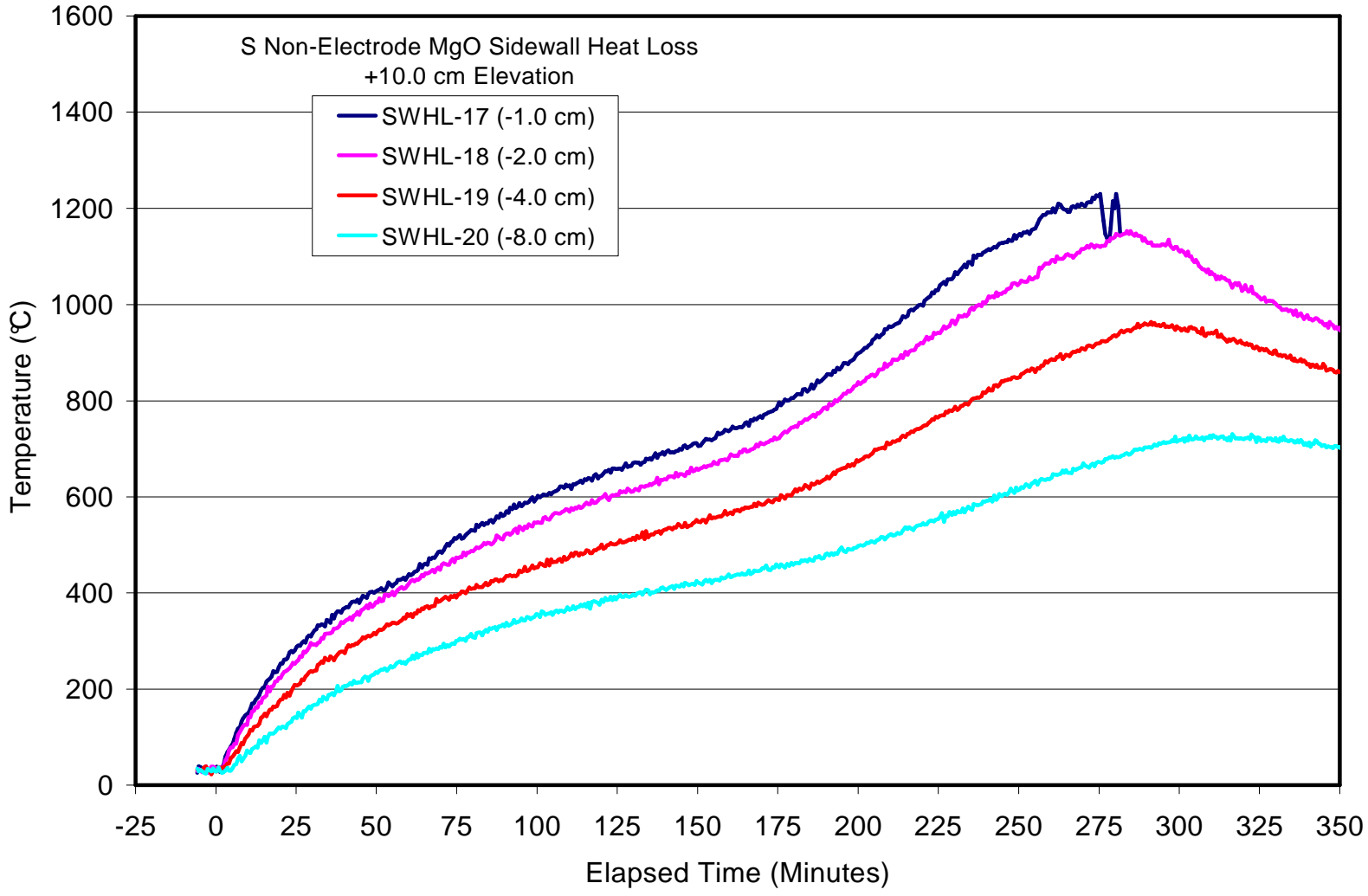

Figure B-34. Test Section Sidewall Heat Loss Data at $+\mathbf{1 0 . 0} \mathbf{~ c m}$ Elevation. 
OECD/MCCI-2009-TR06 Rev. 1

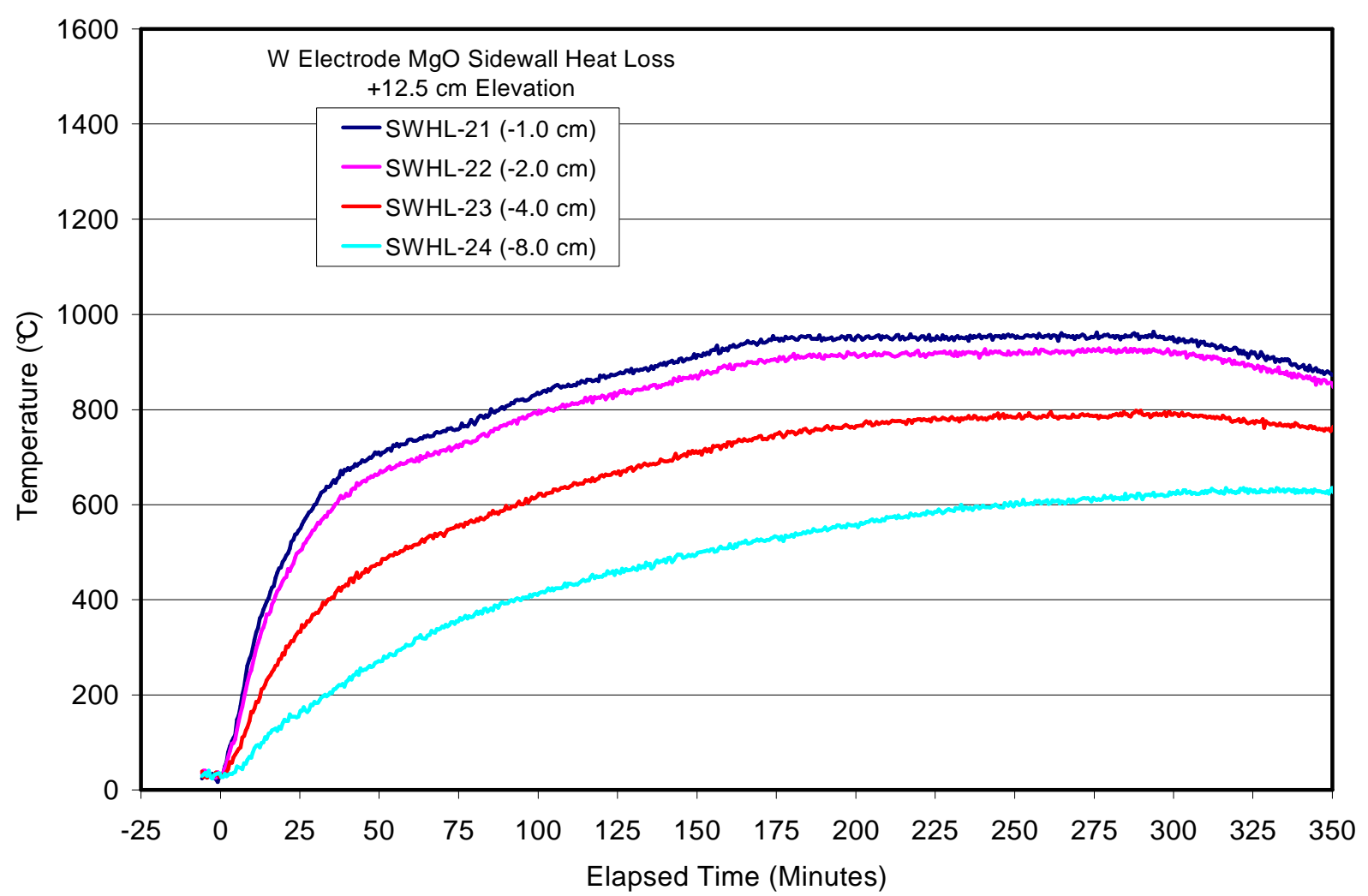

Figure B-35. Test Section Sidewall Heat Loss Data at $+12.5 \mathrm{~cm}$ Elevation.

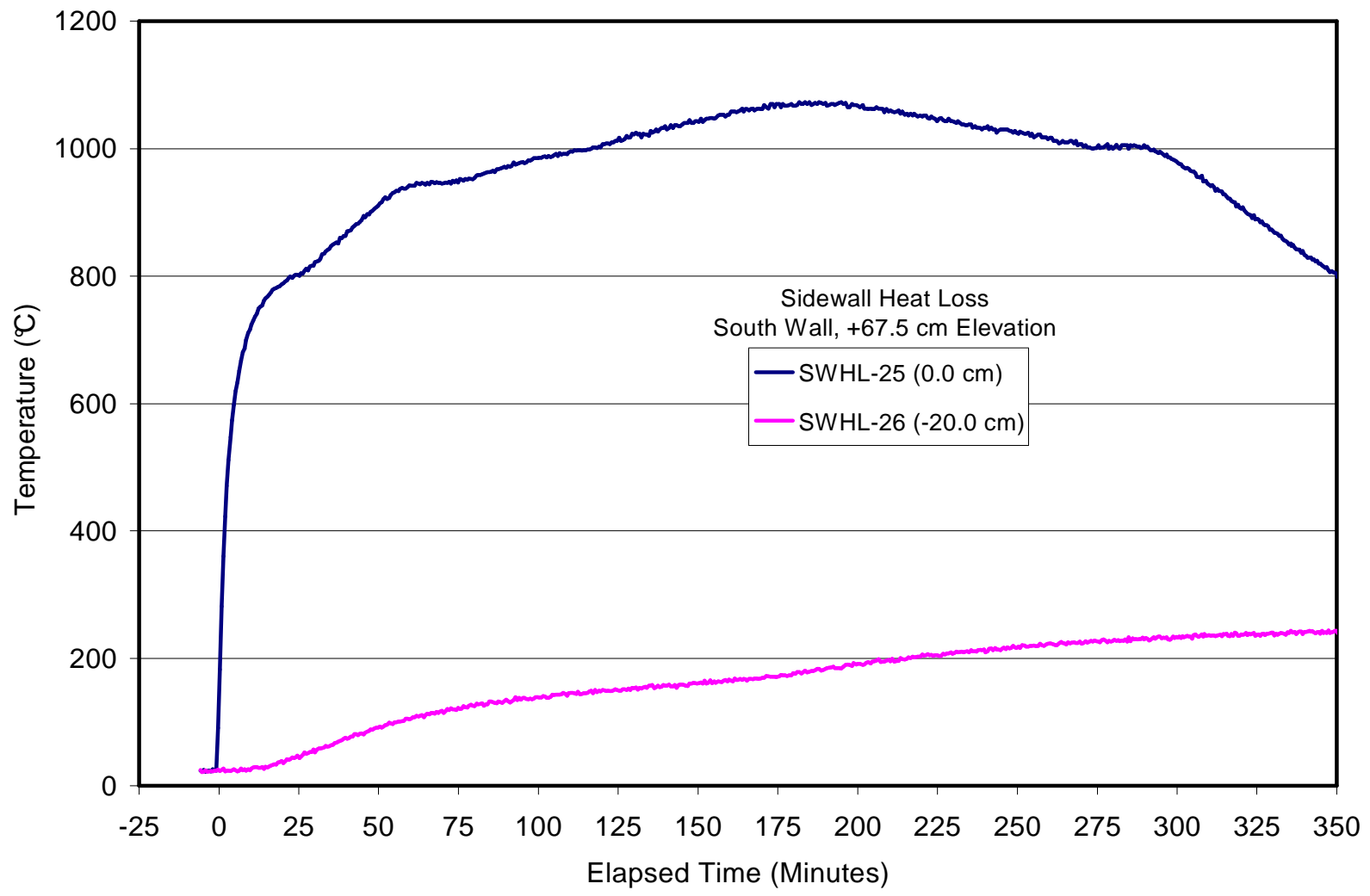

Figure B-36. Test Section Sidewall Heat Loss Data at the $+67.5 \mathrm{~cm}$ Elevation. 
OECD/MCCI-2009-TR06 Rev. 1

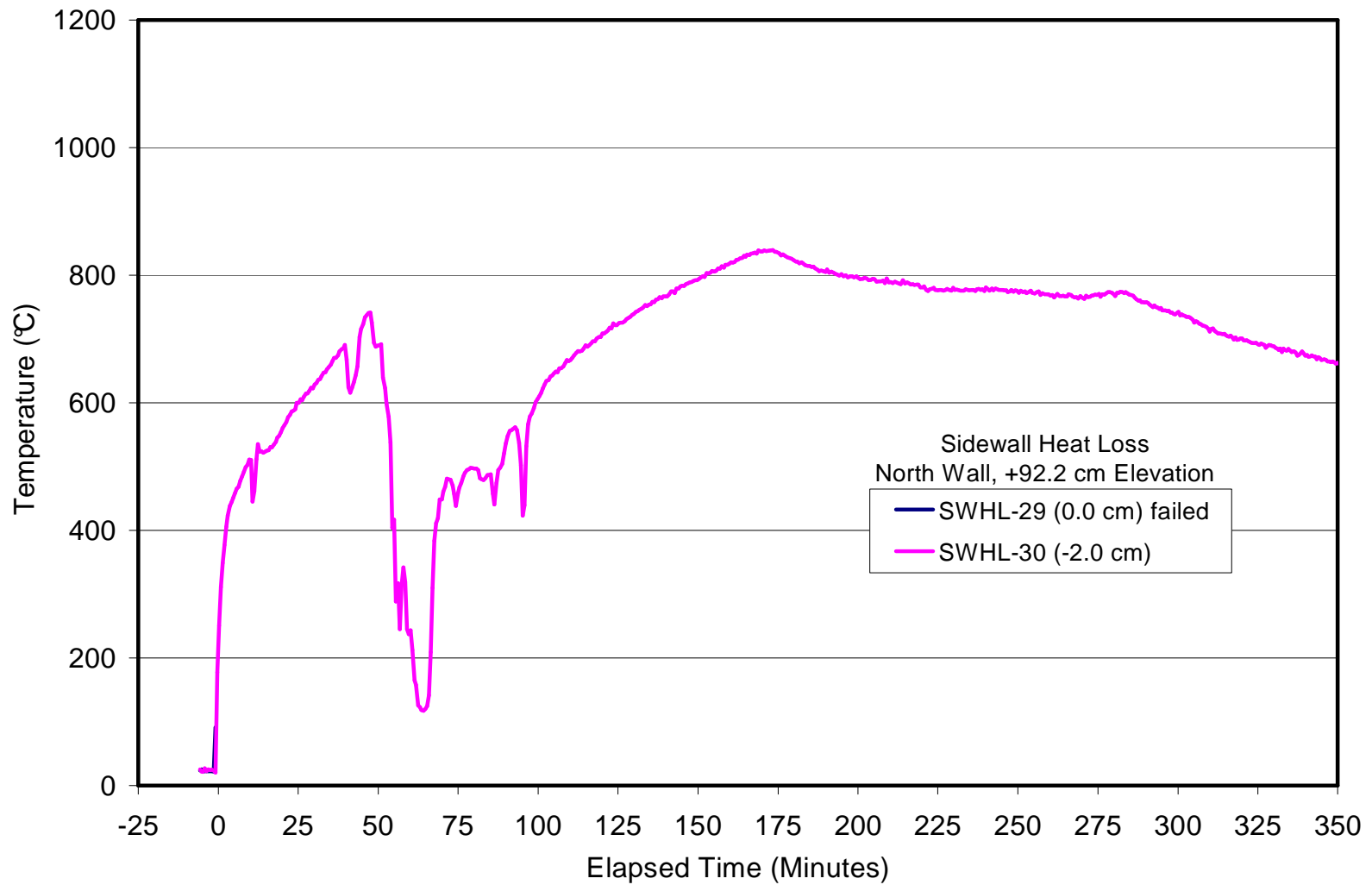

Figure B-37. Test Section Sidewall Heat Loss Data at the $+\mathbf{9 2 . 2} \mathrm{cm}$ Elevation.

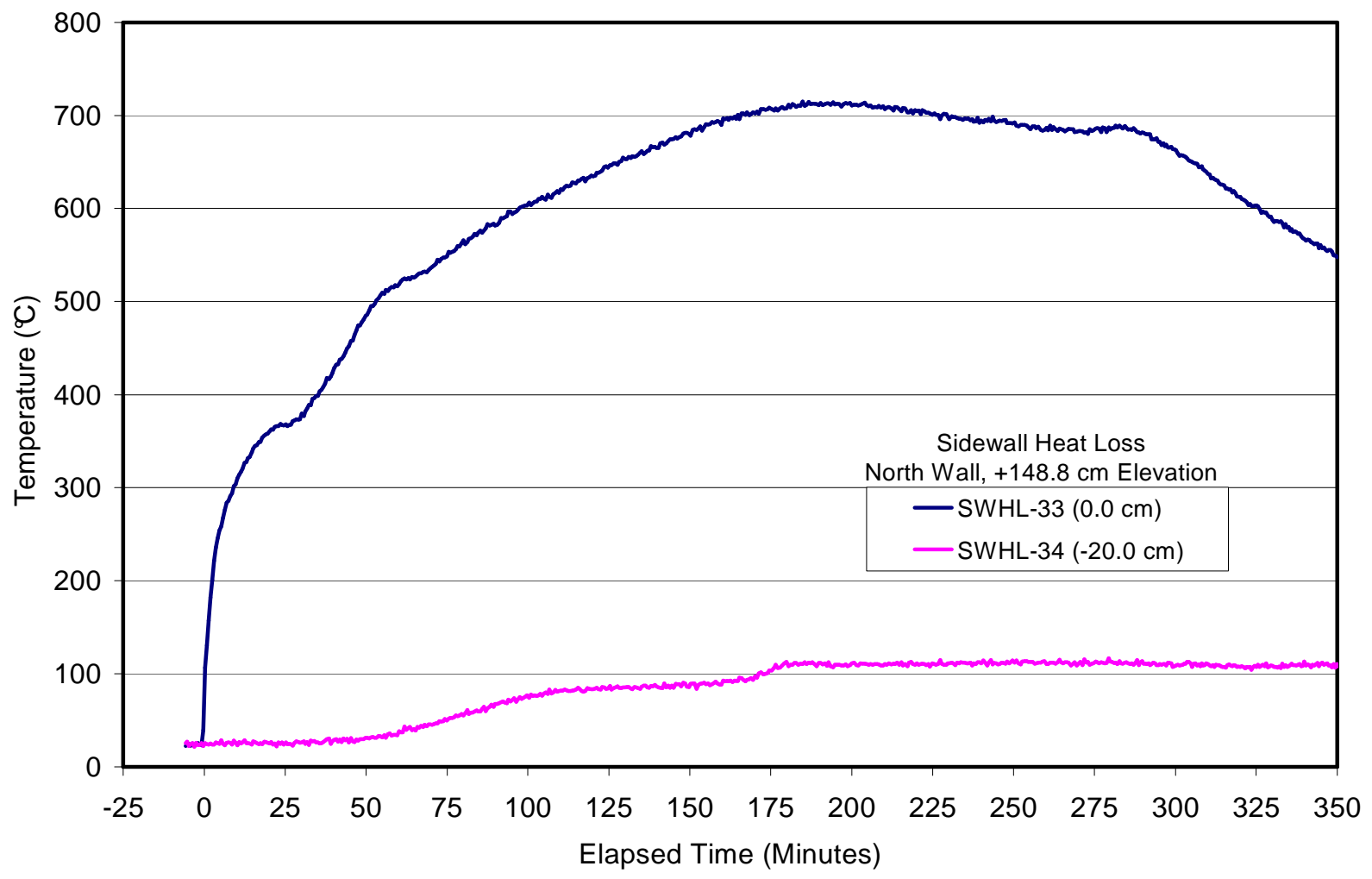

Figure B-38. Test Section Sidewall Heat Loss Data at the $+\mathbf{1 4 8 . 8} \mathrm{cm}$ Elevation. 
OECD/MCCI-2009-TR06 Rev. 1

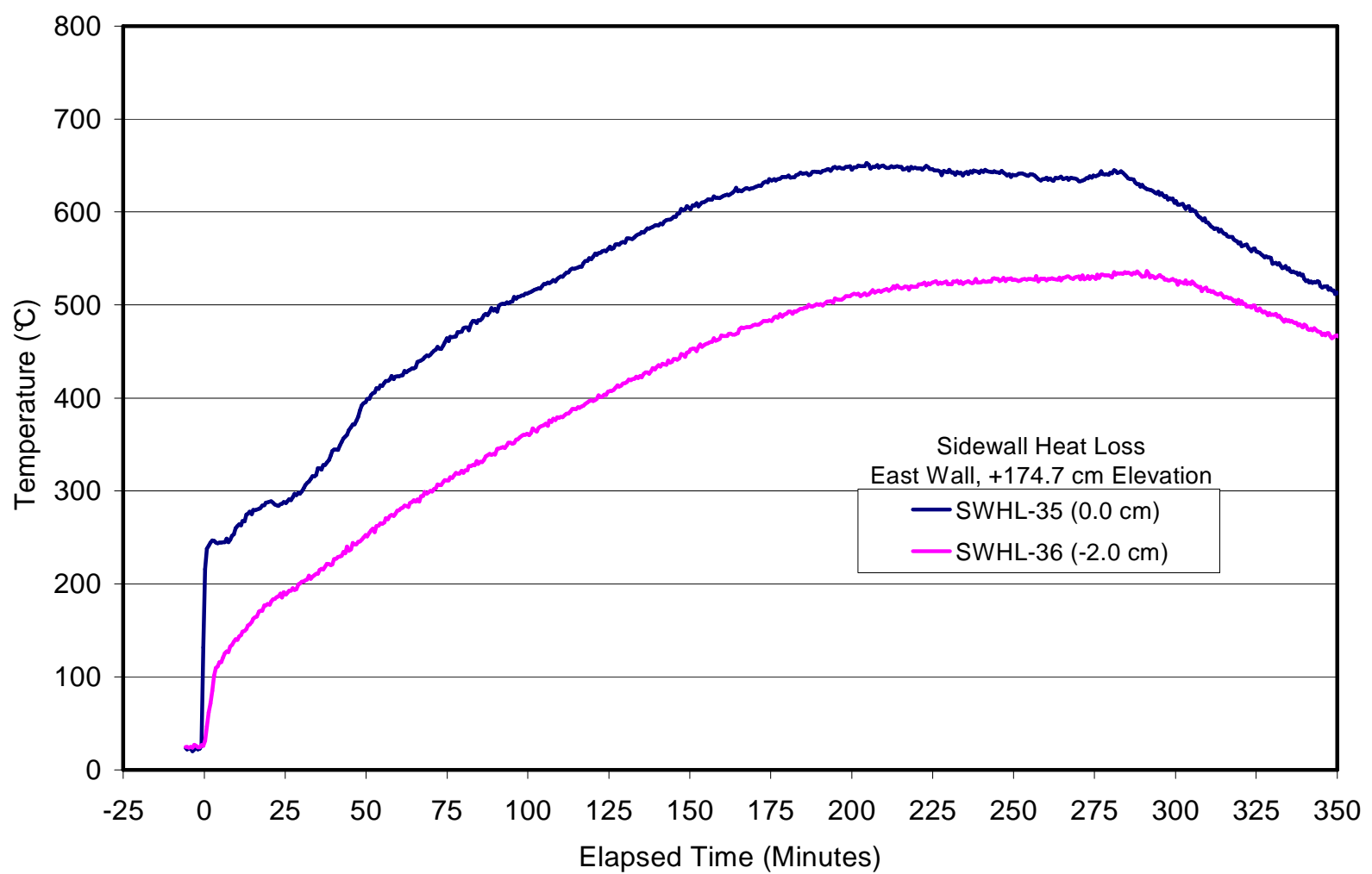

Figure B-39. Test Section Sidewall Heat Loss Data at the $+\mathbf{1 7 4 . 7} \mathrm{cm}$ Elevation.

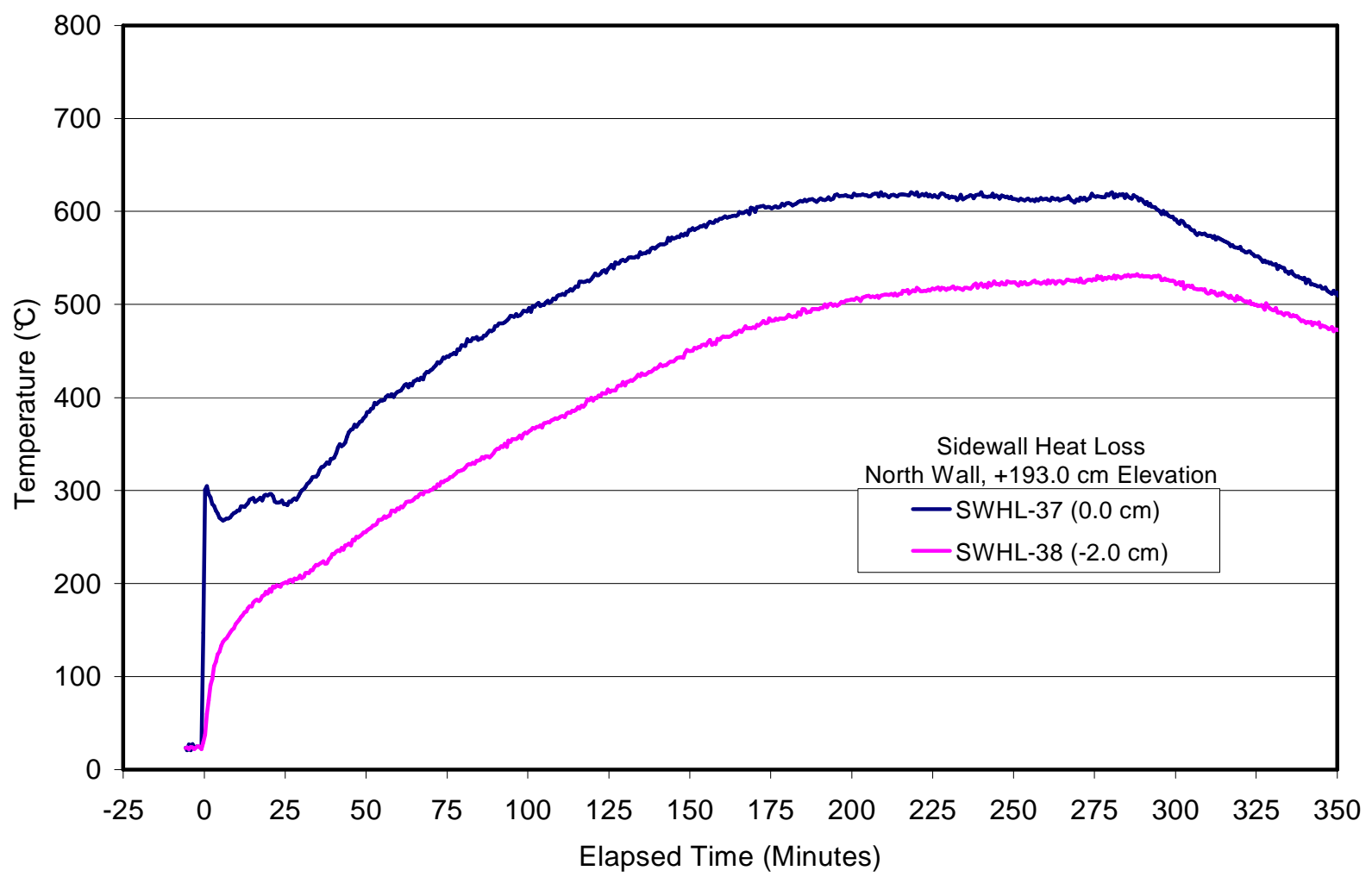

Figure B-40. Test Section Sidewall Heat Loss Data at the $+193.0 \mathrm{~cm}$ Elevation. 
OECD/MCCI-2009-TR06 Rev. 1

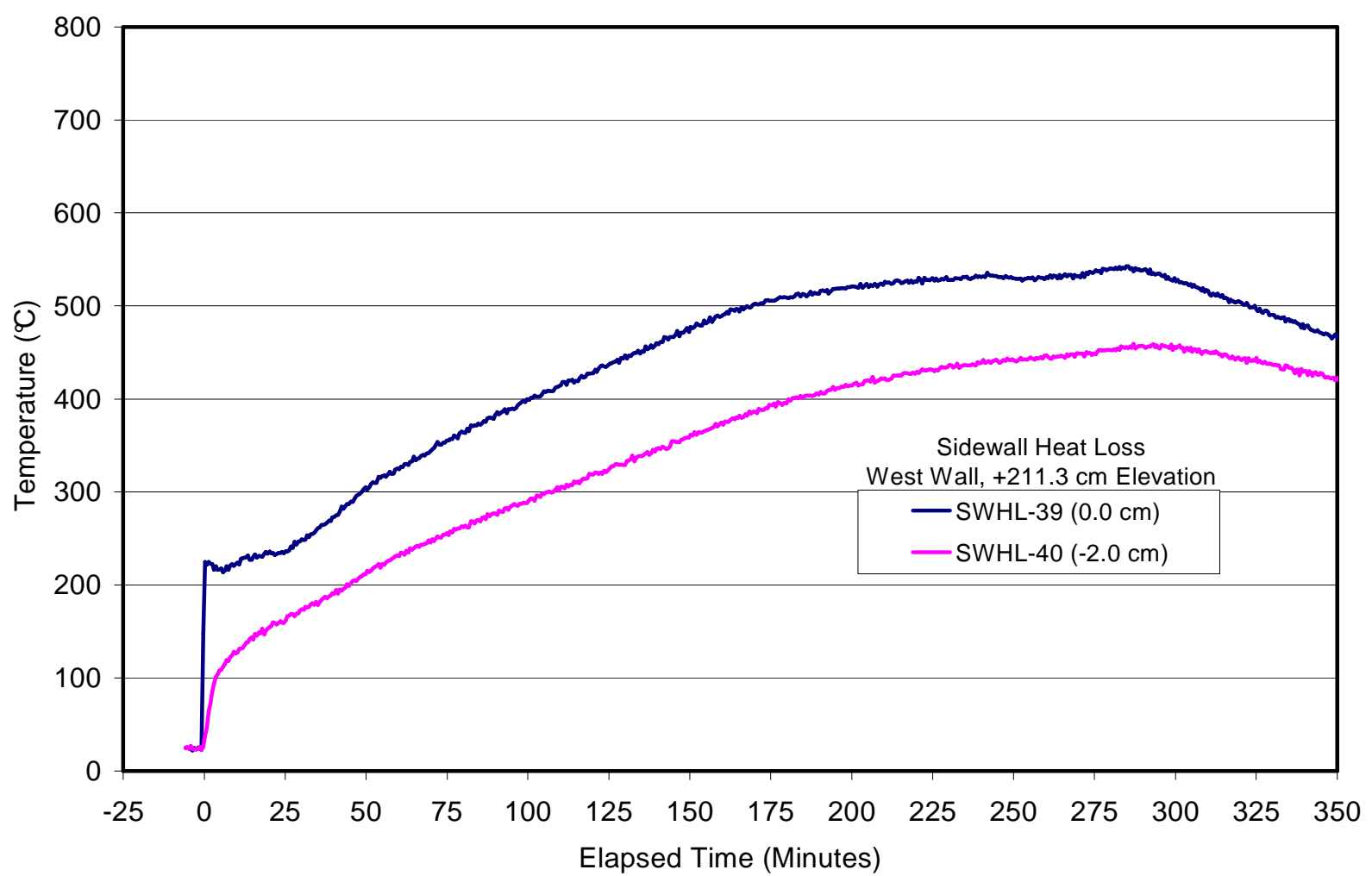

Figure B-41. Test Section Sidewall Heat Loss Data at the $+211.3 \mathrm{~cm}$ Elevation.

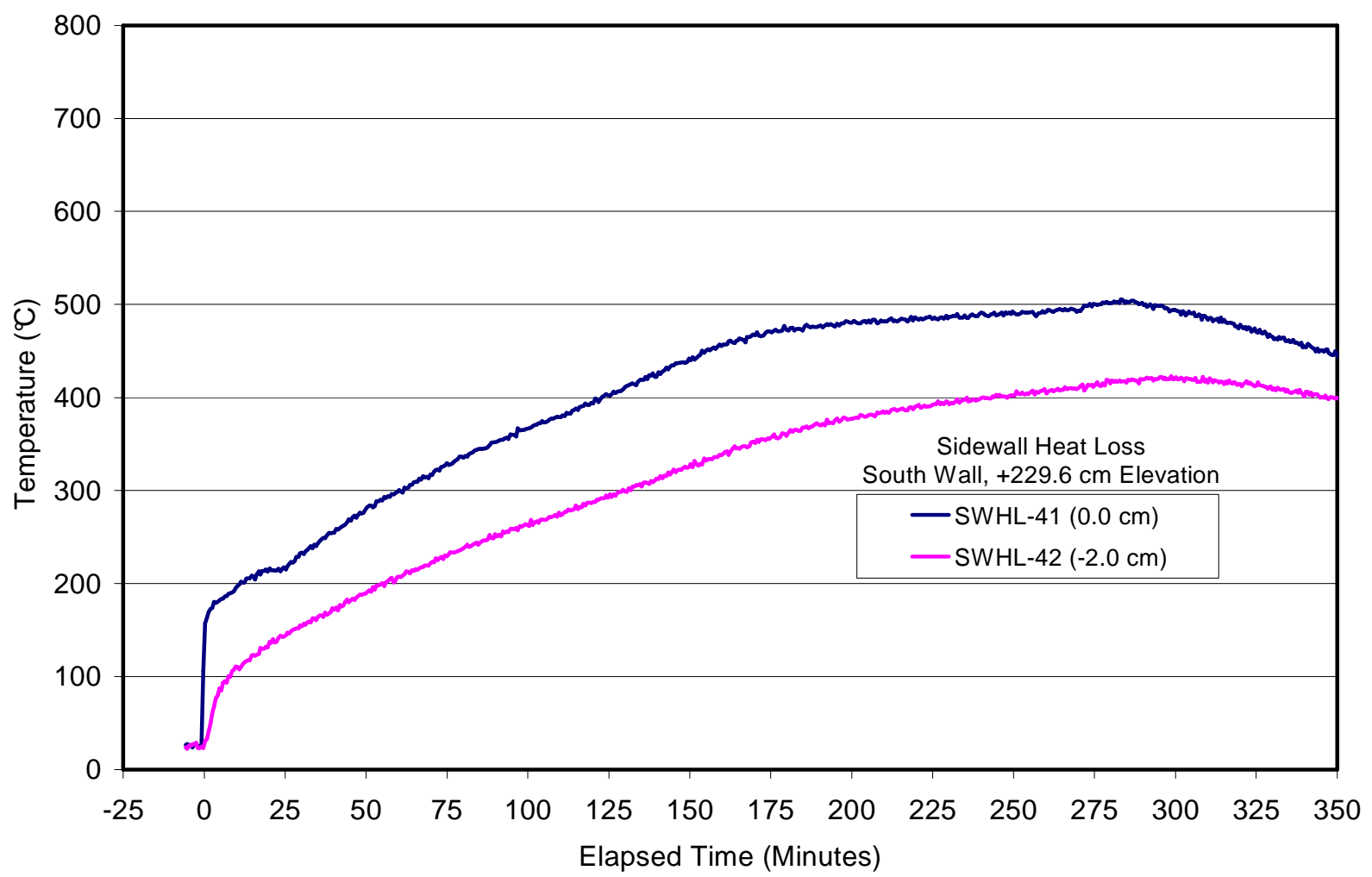

Figure B-42. Test Section Sidewall Heat Loss Data at the $+229.6 \mathrm{~cm}$ Elevation. 
OECD/MCCI-2009-TR06 Rev. 1

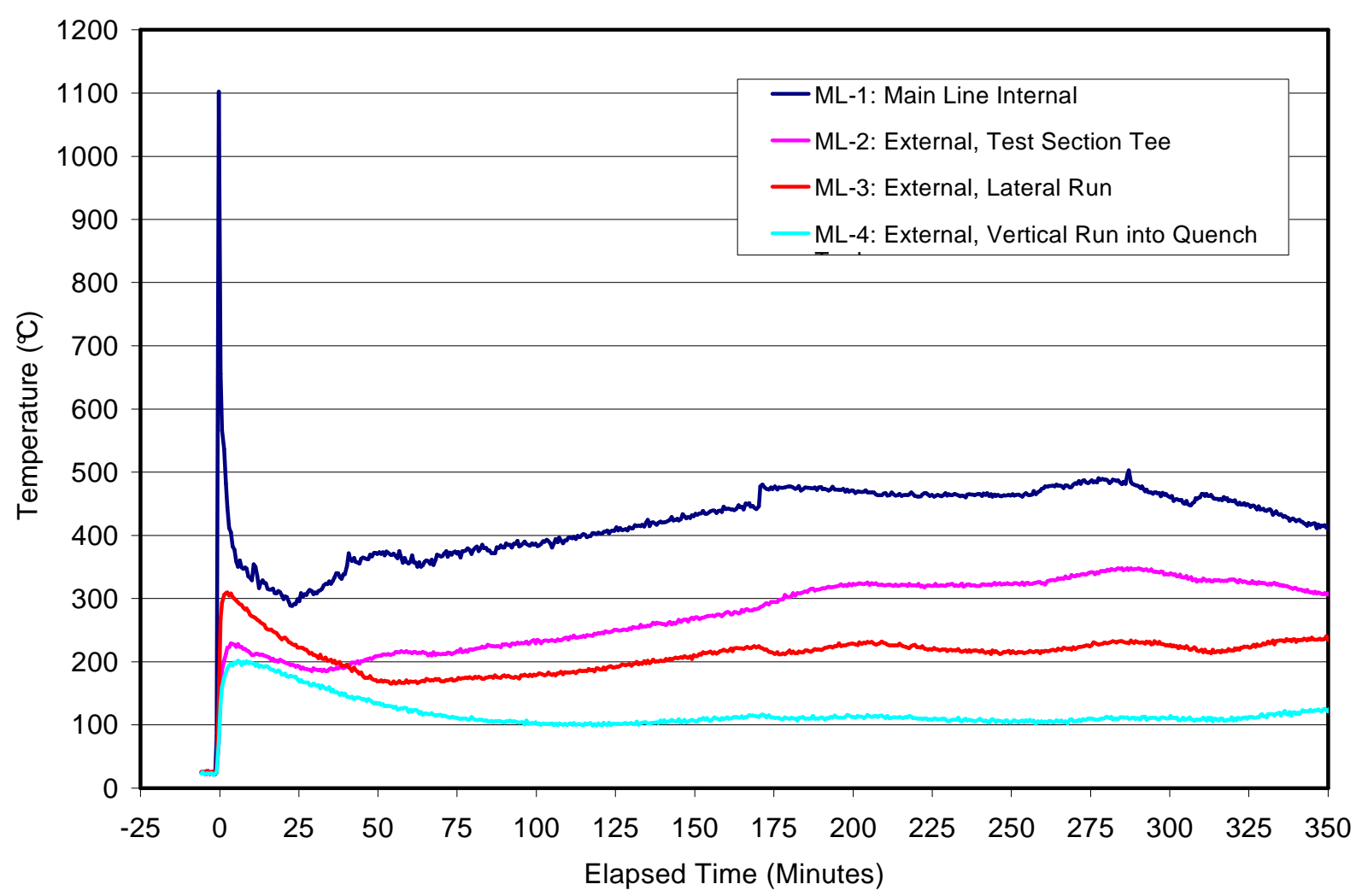

Figure B-43. Test Section Mainline Thermocouple Data.

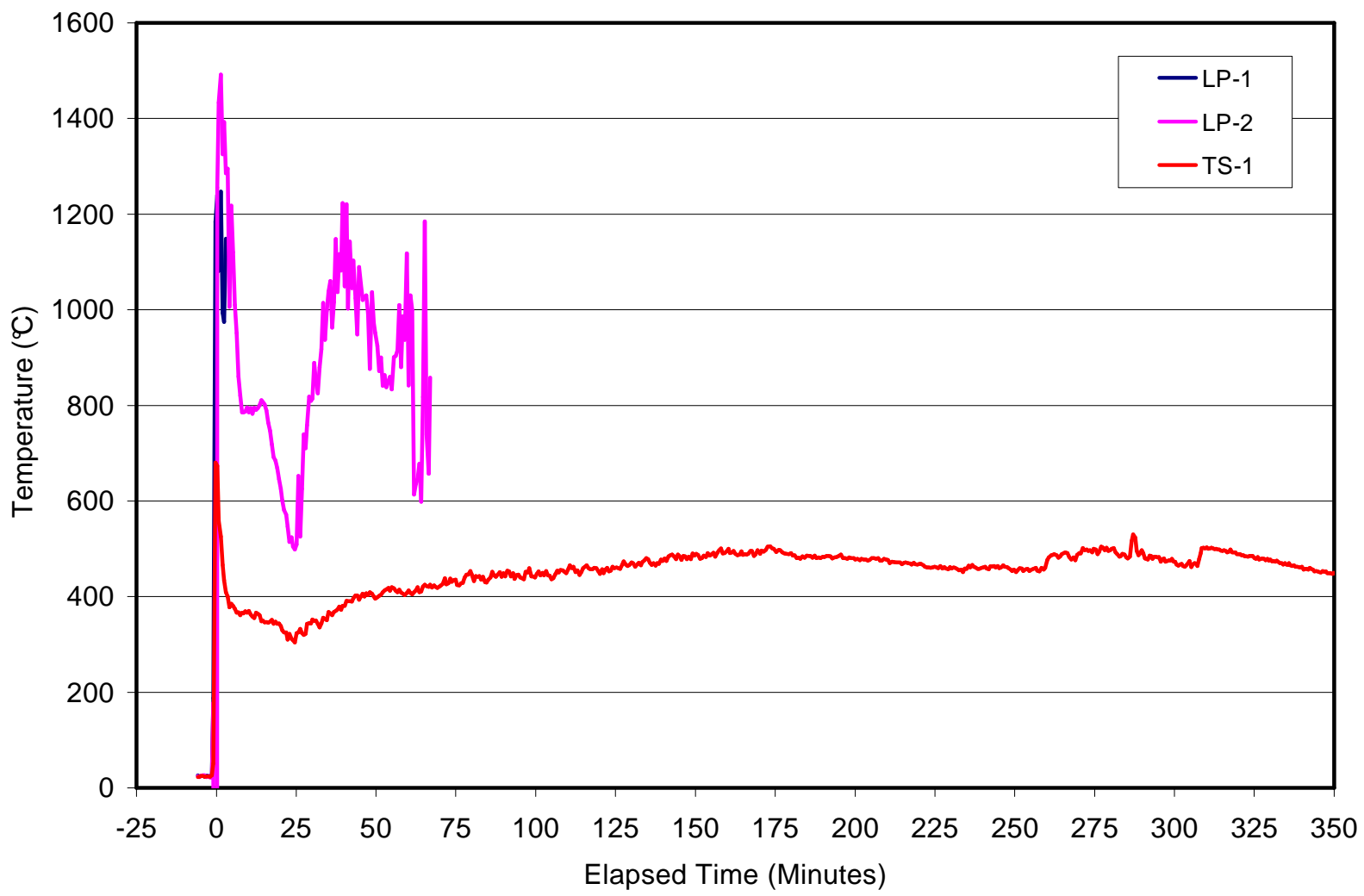

Figure B-44. Test Section Plenum and Insertable Water Probe Thermocouple Data. 
OECD/MCCI-2009-TR06 Rev. 1

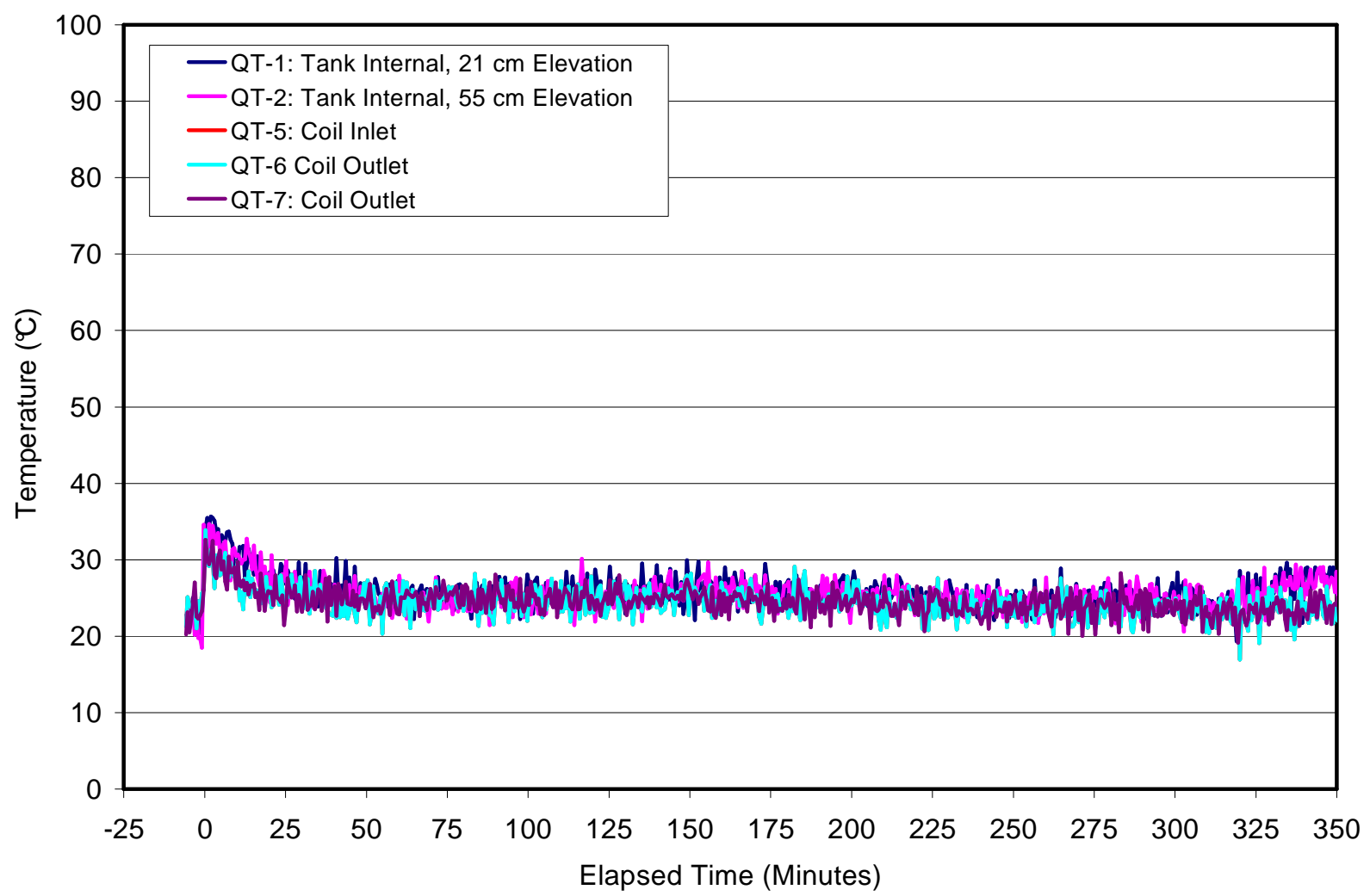

Figure B-45. Quench Tank Water Volume, Coil Inlet, and Coil Outlet Temperatures.

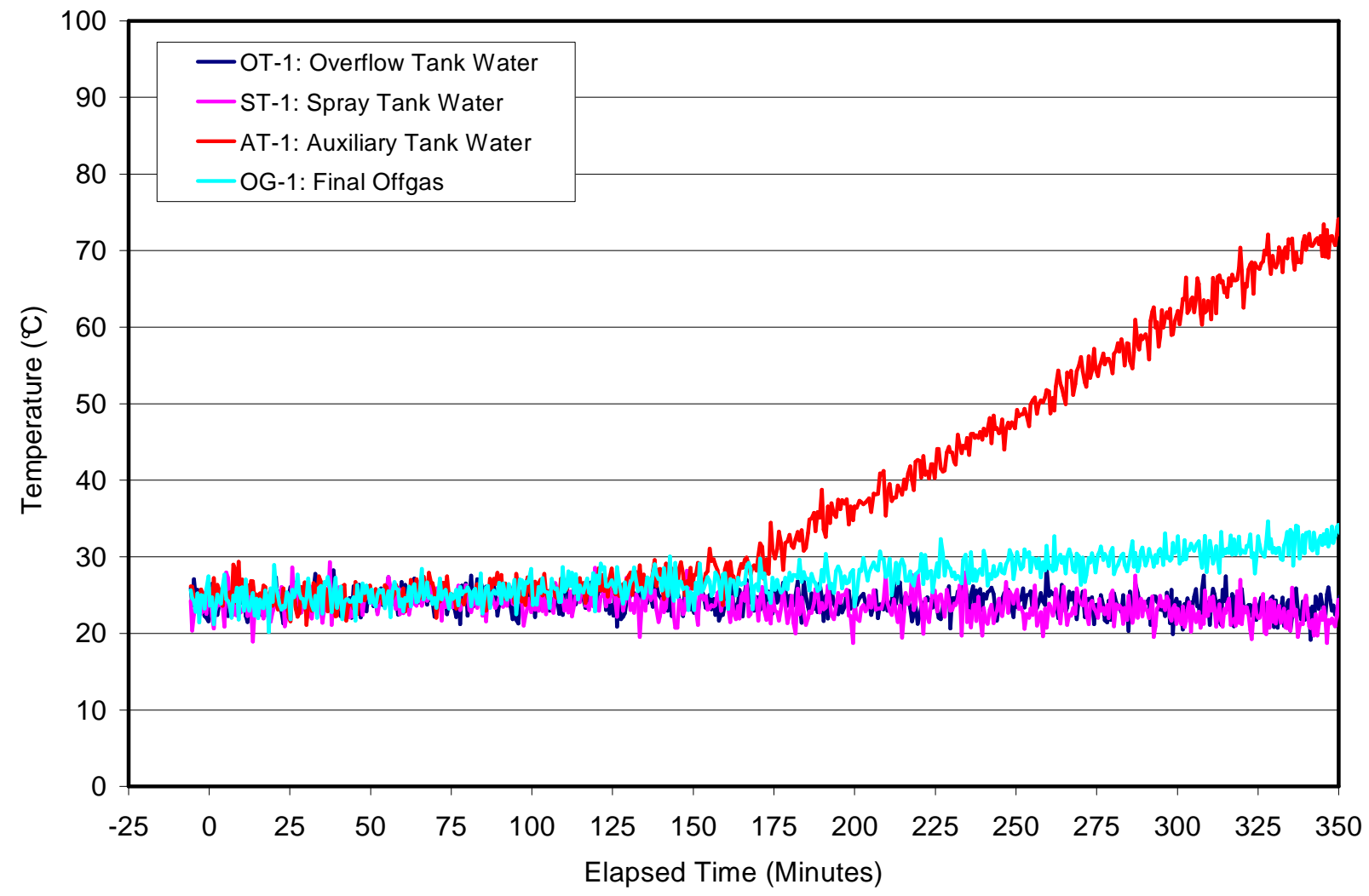

Figure B-46. Temperatures in Water Supply, Quench, and Off Gas Systems. 
OECD/MCCI-2009-TR06 Rev. 1

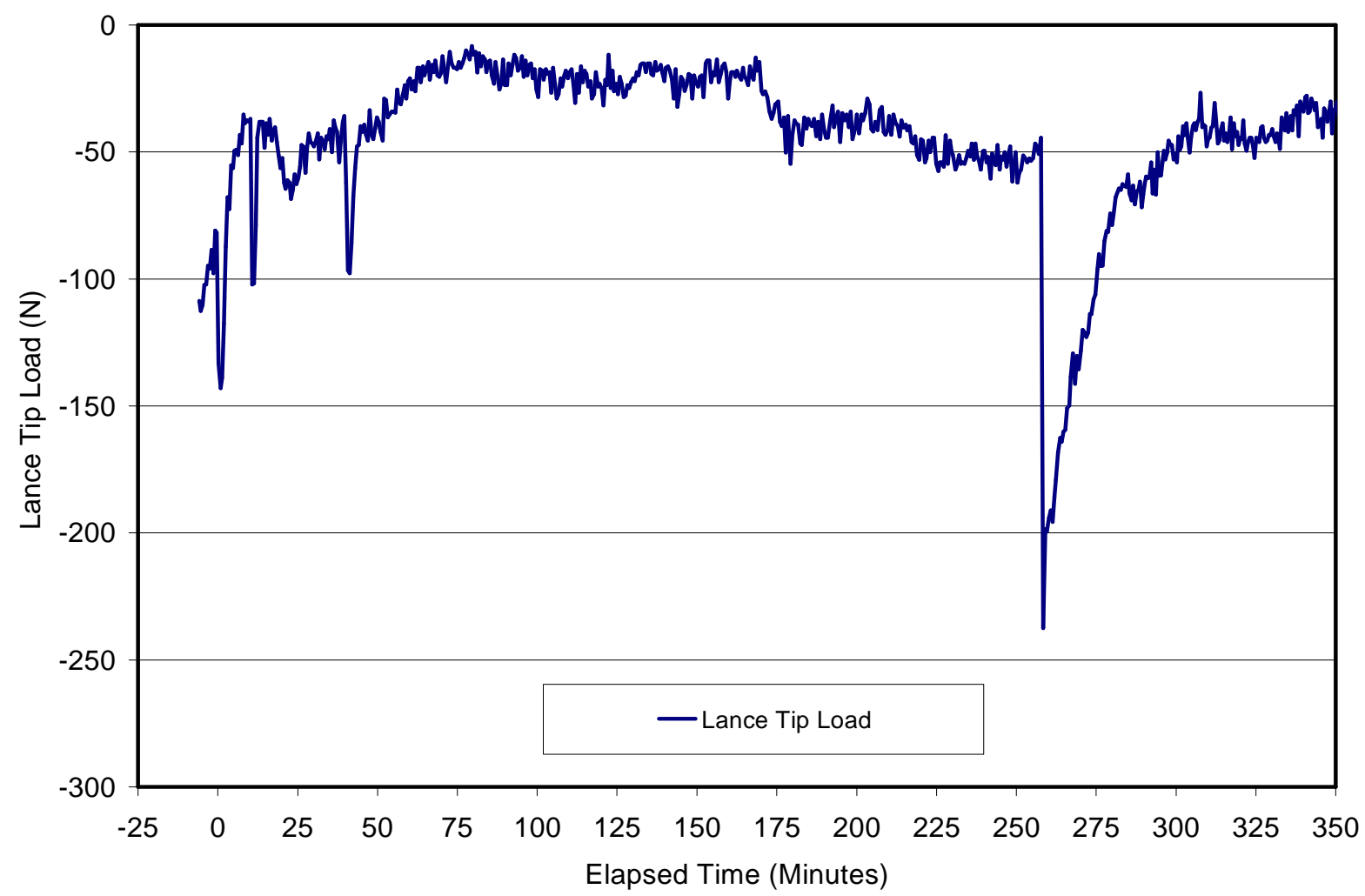

Figure B-47. Crust Lance Load Cell Data.

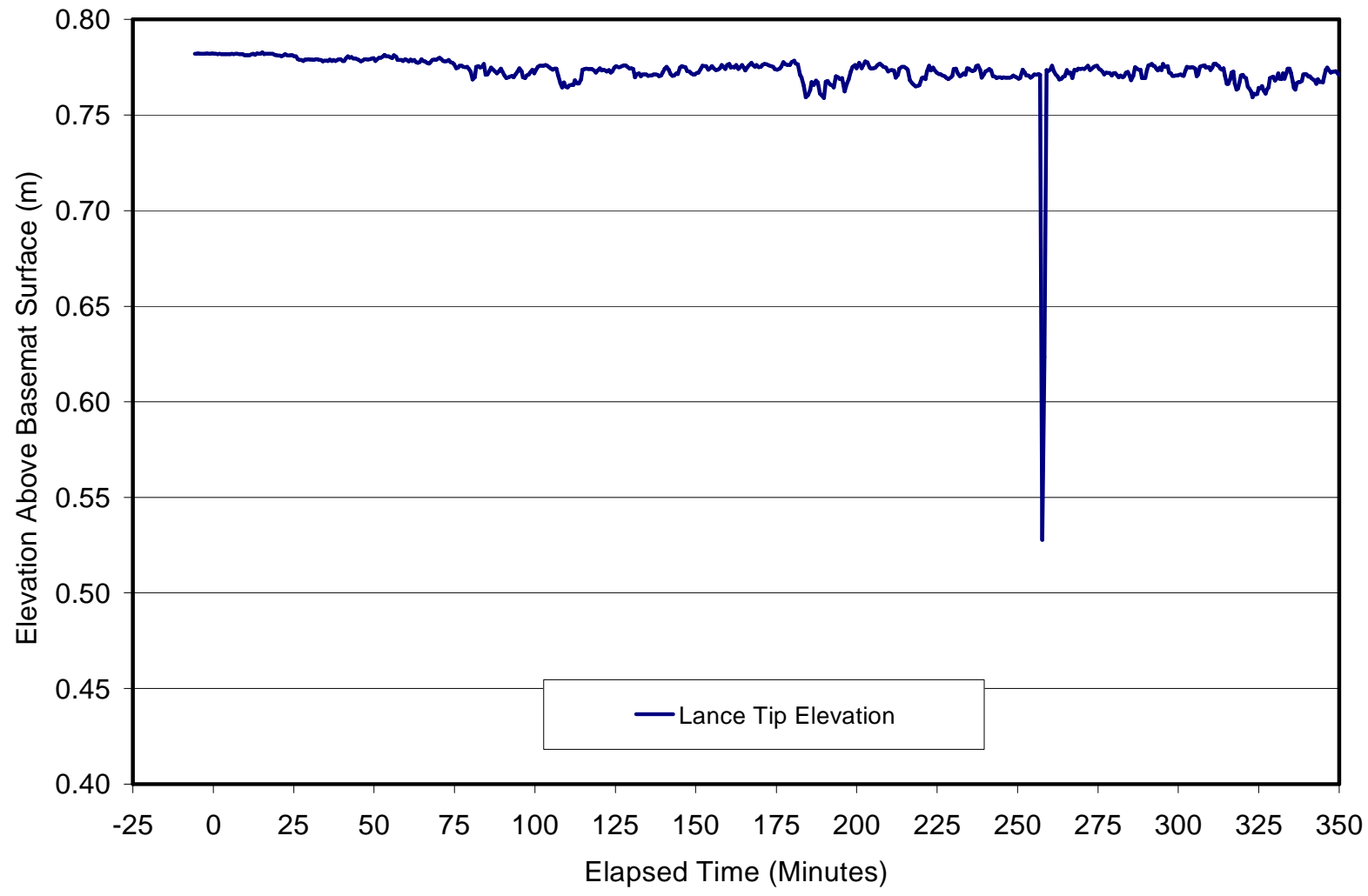

Figure B-48. Lance Position Indicator Data. 
OECD/MCCI-2009-TR06 Rev. 1

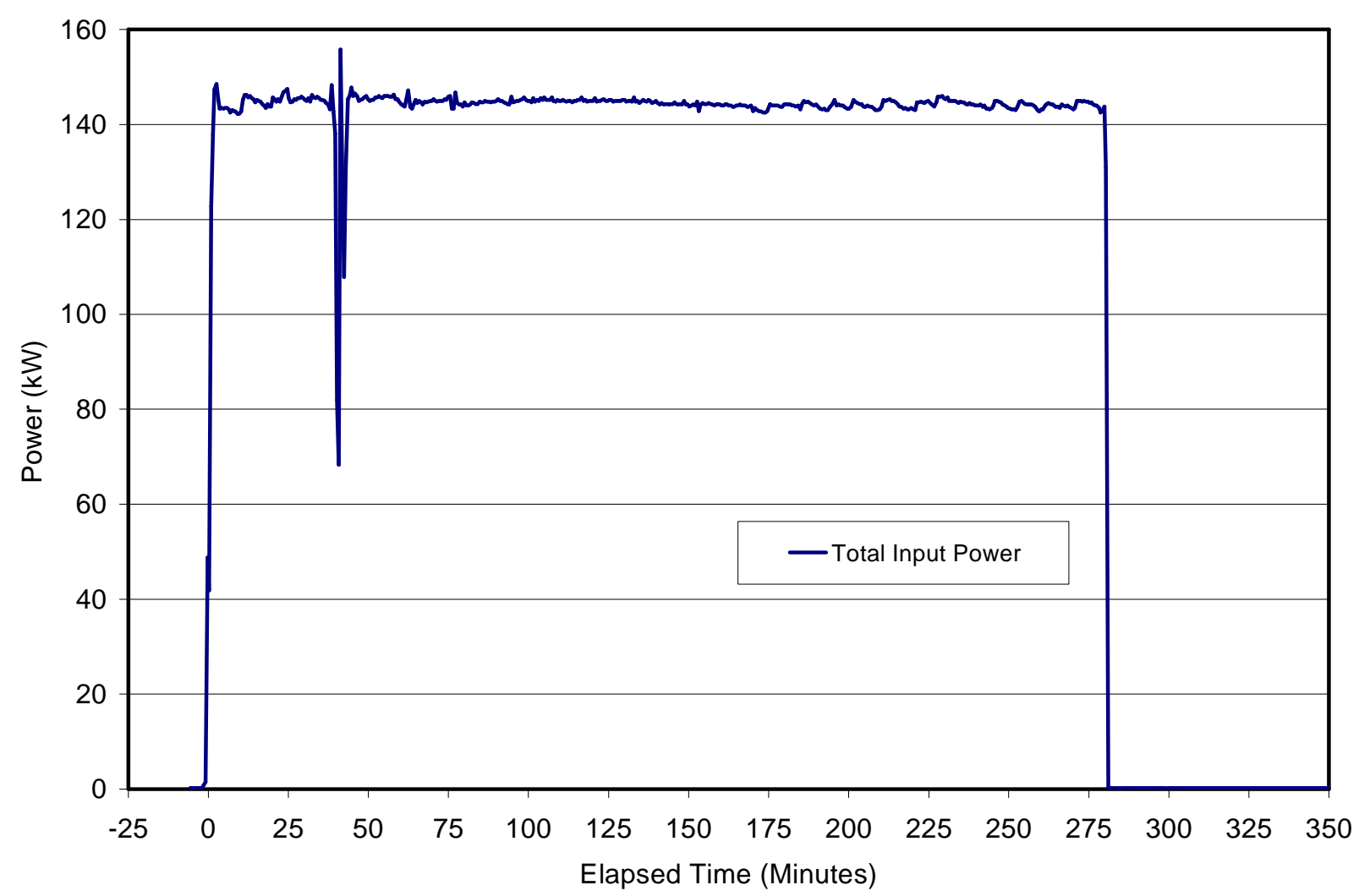

Figure B-49. Total Power Supply Power.

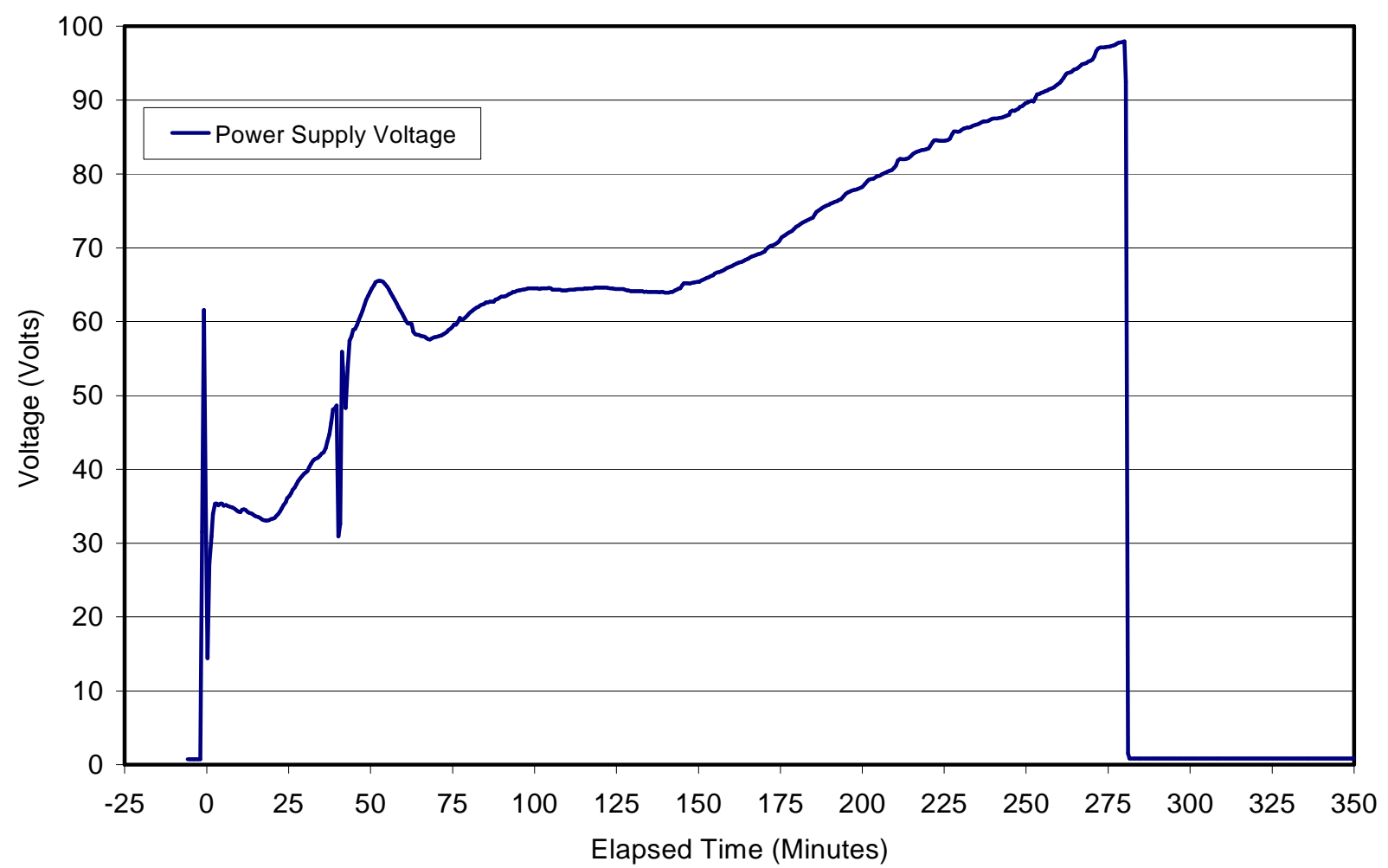

Figure B-50 Power Supply Voltage Data. 
OECD/MCCI-2009-TR06 Rev. 1

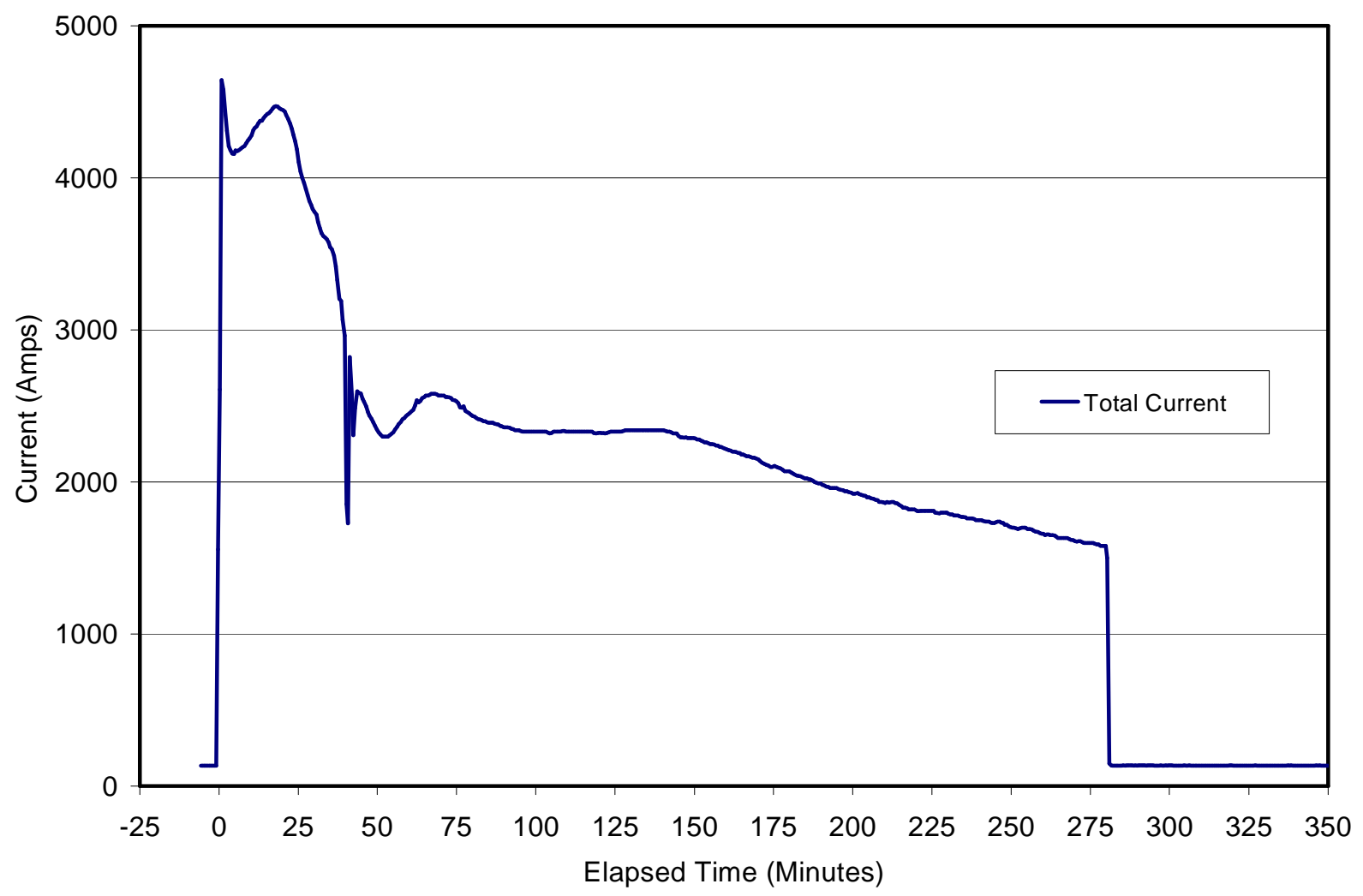

Figure B-51. Total Power Supply Current Data.

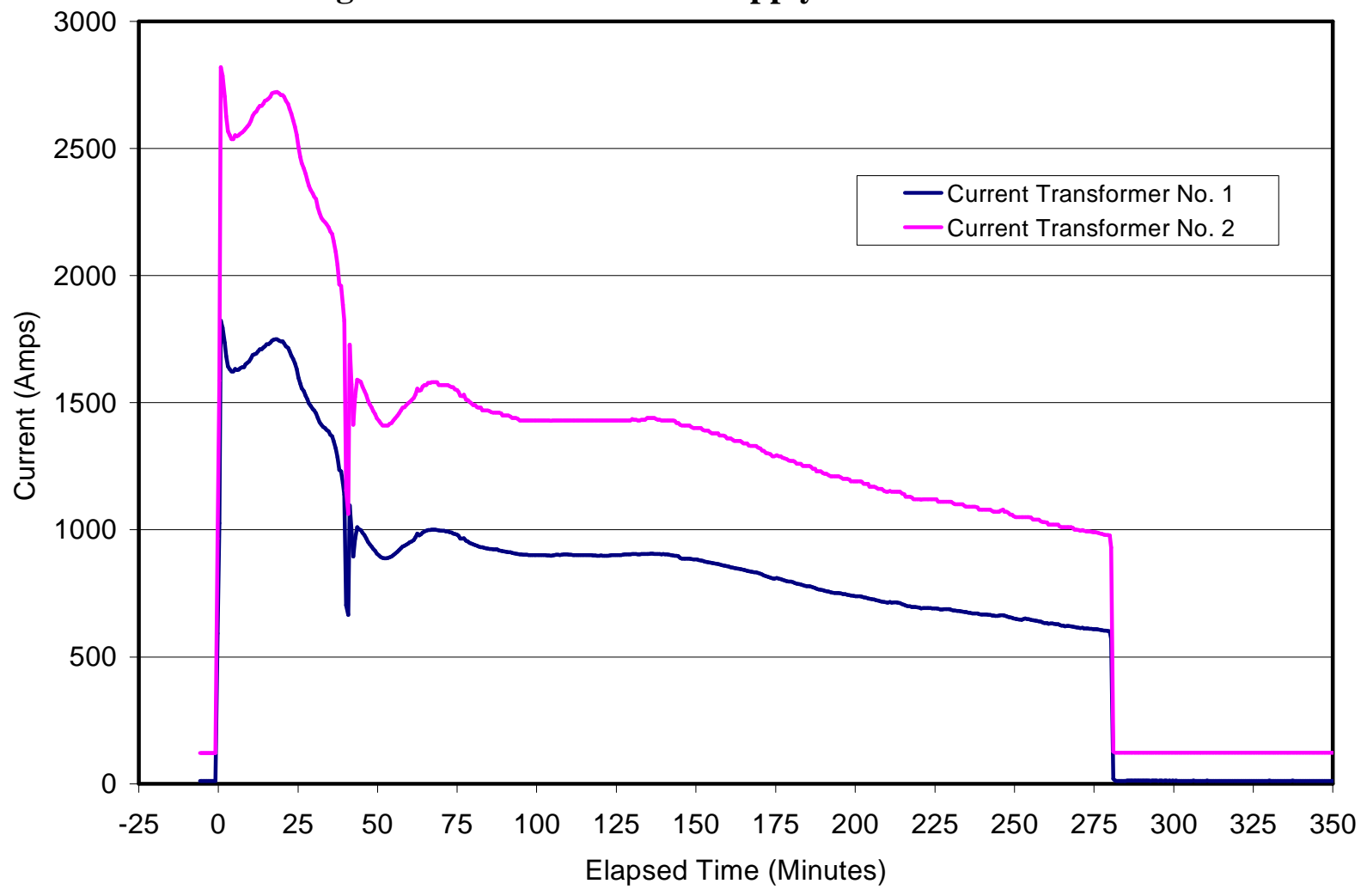

Figure B-52. Power Supply Current Transformer Data. 
OECD/MCCI-2009-TR06 Rev. 1

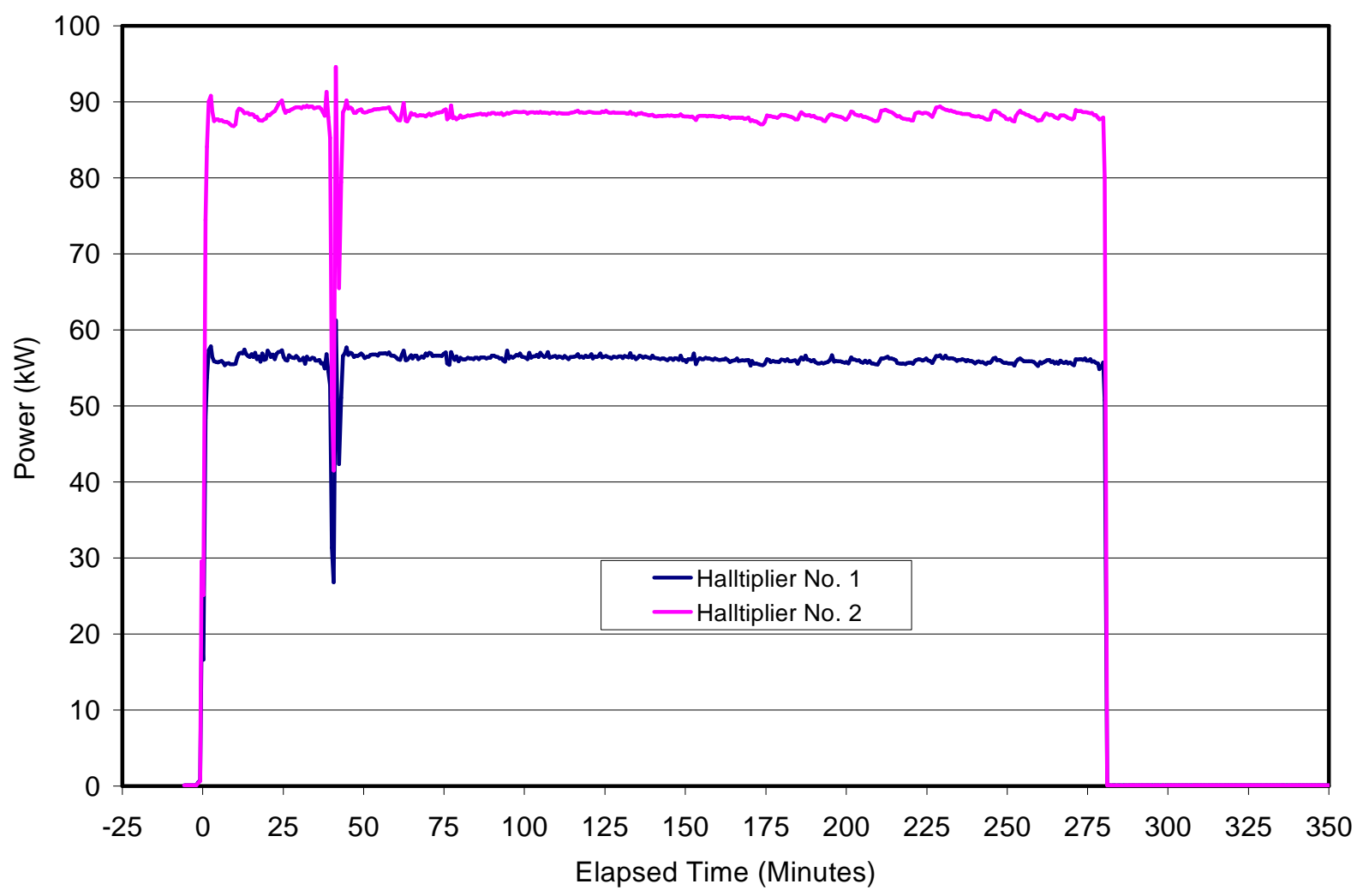

Figure B-53. Hall Effect Meter Data.

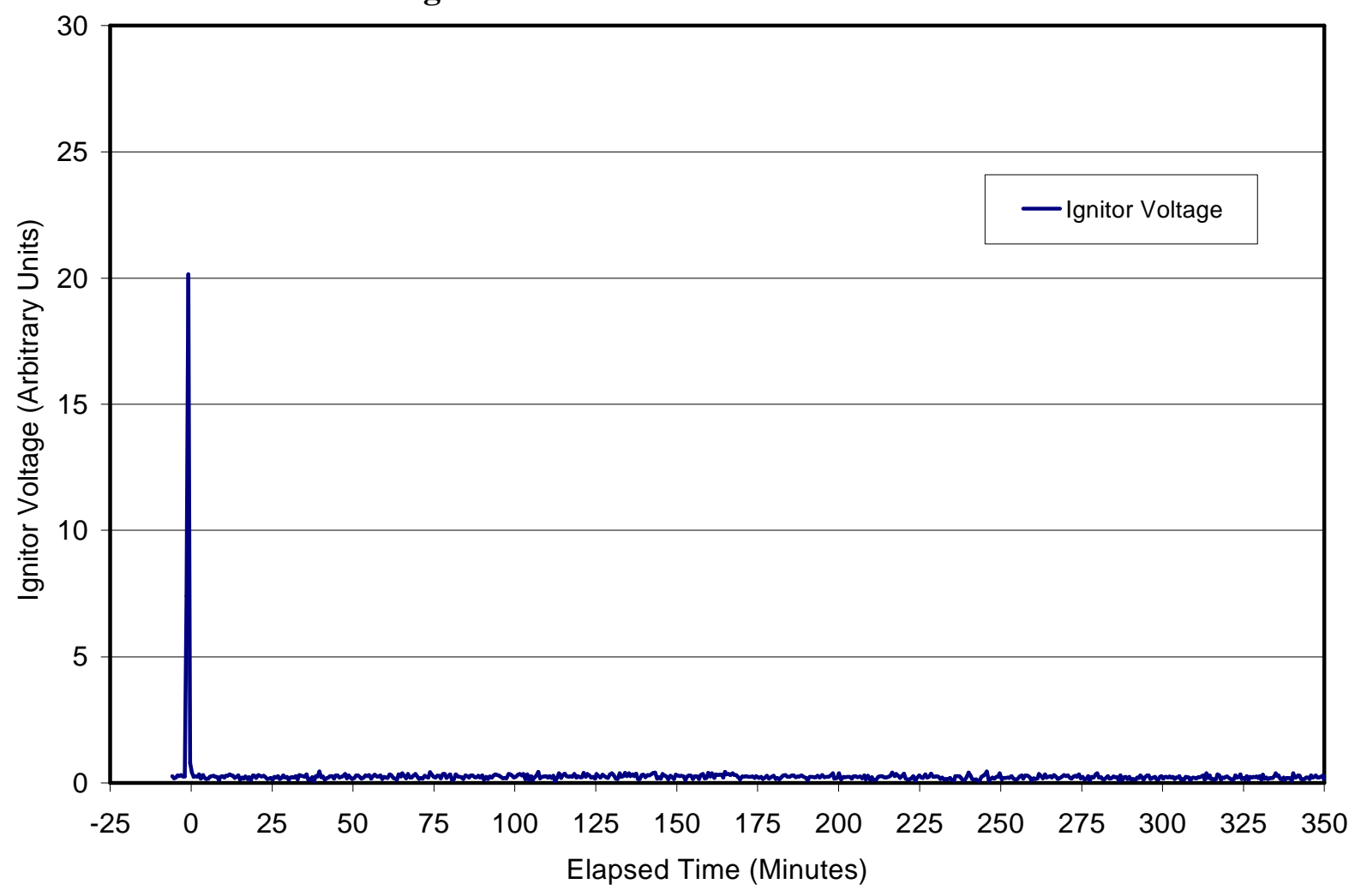

Figure B-54. Voltage across Igniter Shunt. 
OECD/MCCI-2009-TR06 Rev. 1

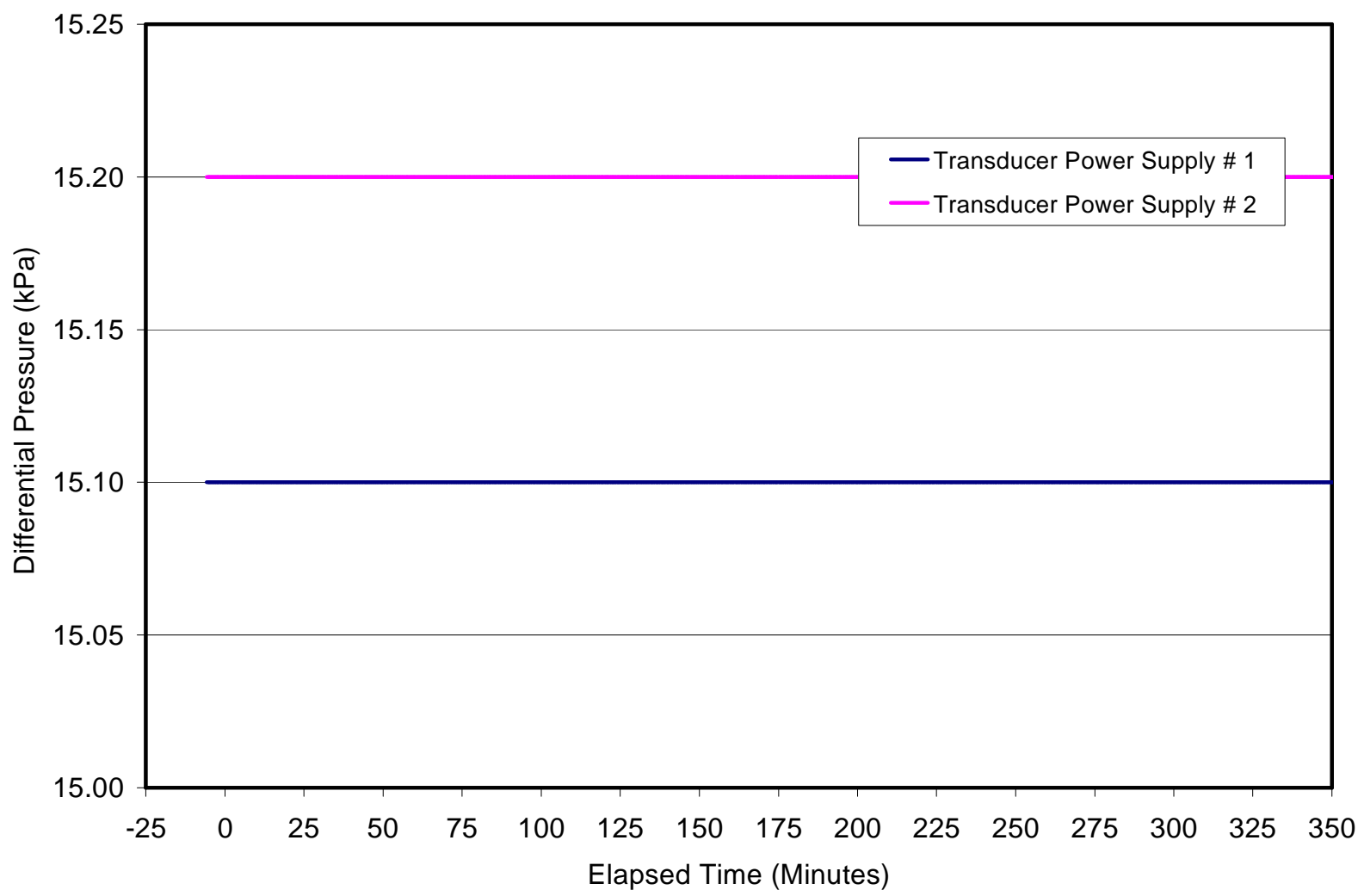

Figure B-55. Pressure Transducer Power Supply Voltages.

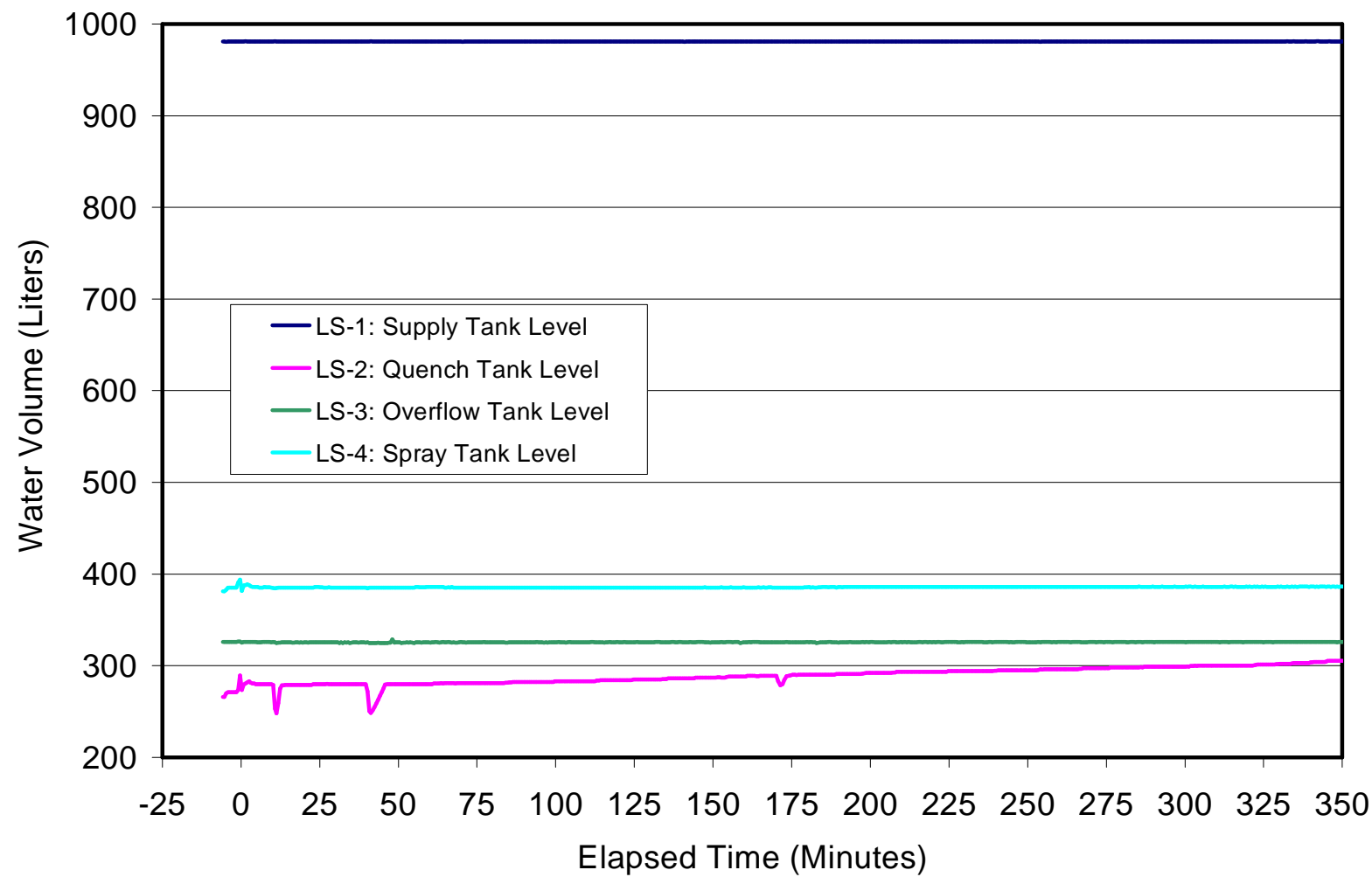

Figure B-56. Tank Water Volume Data. 
OECD/MCCI-2009-TR06 Rev. 1

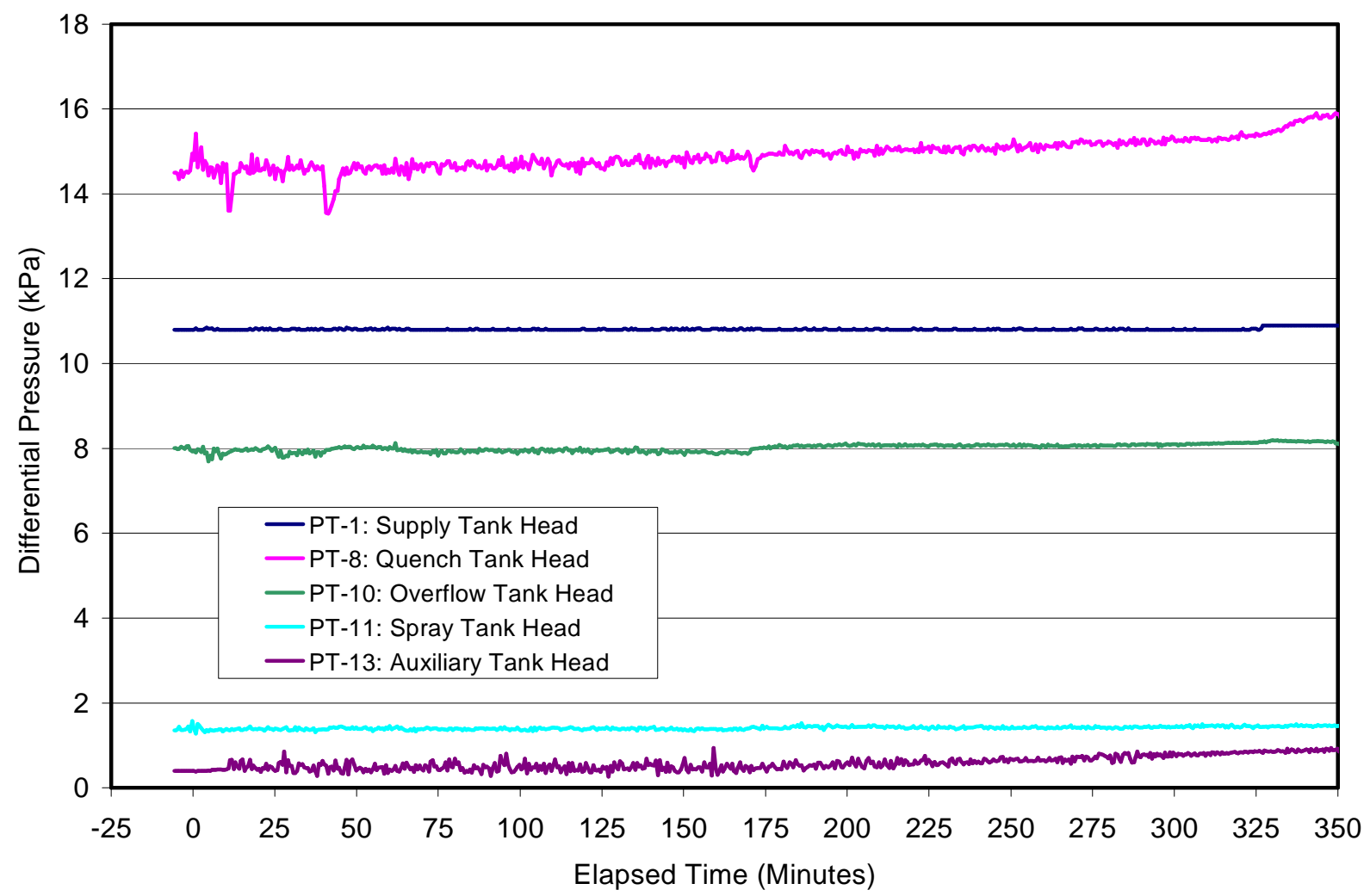

Figure B-57. Supply and Quench System Tank Head Data (Backup).

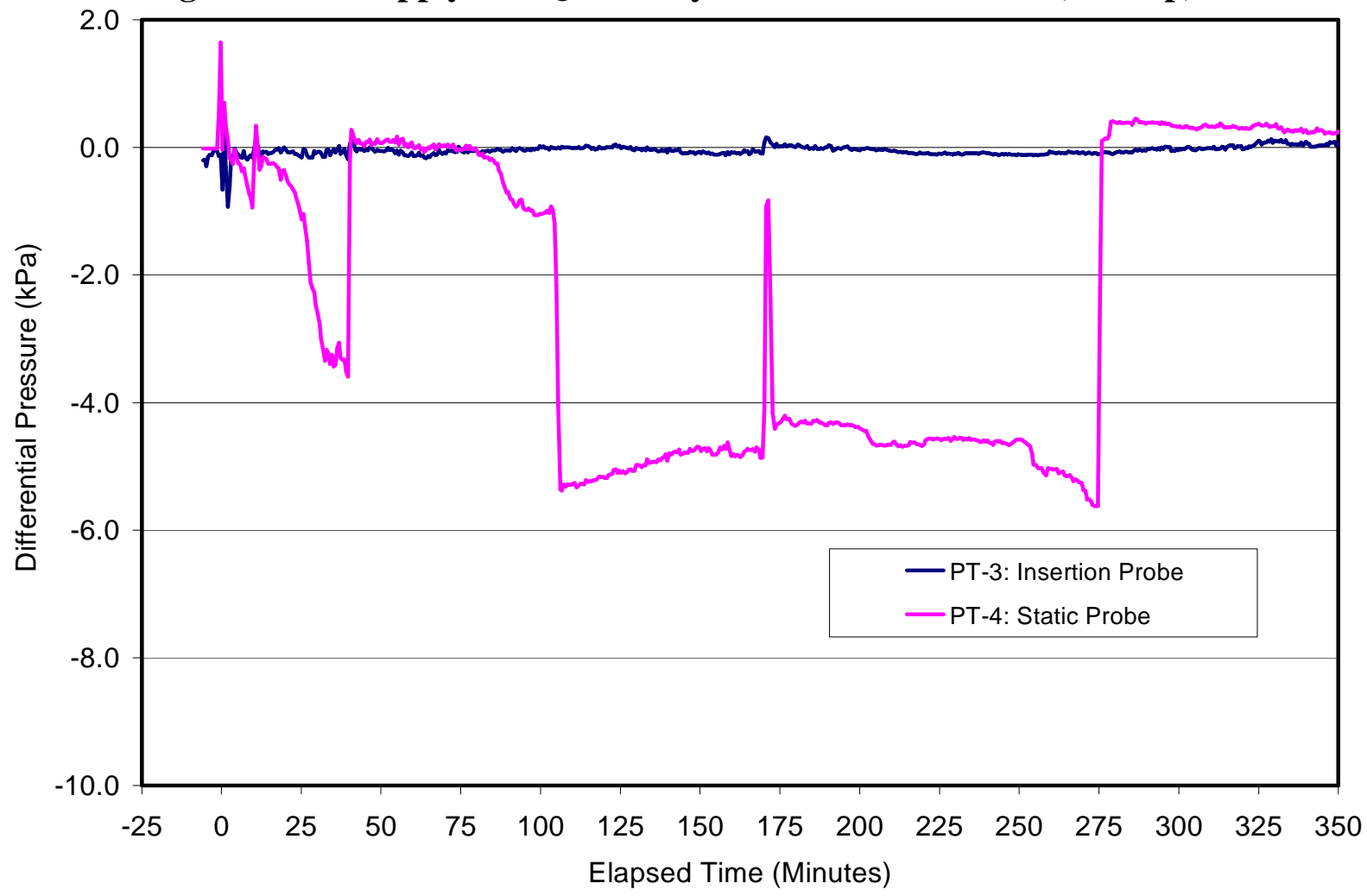

Figure B-58. Test Section Water Head Transducer Data. 
OECD/MCCI-2009-TR06 Rev. 1

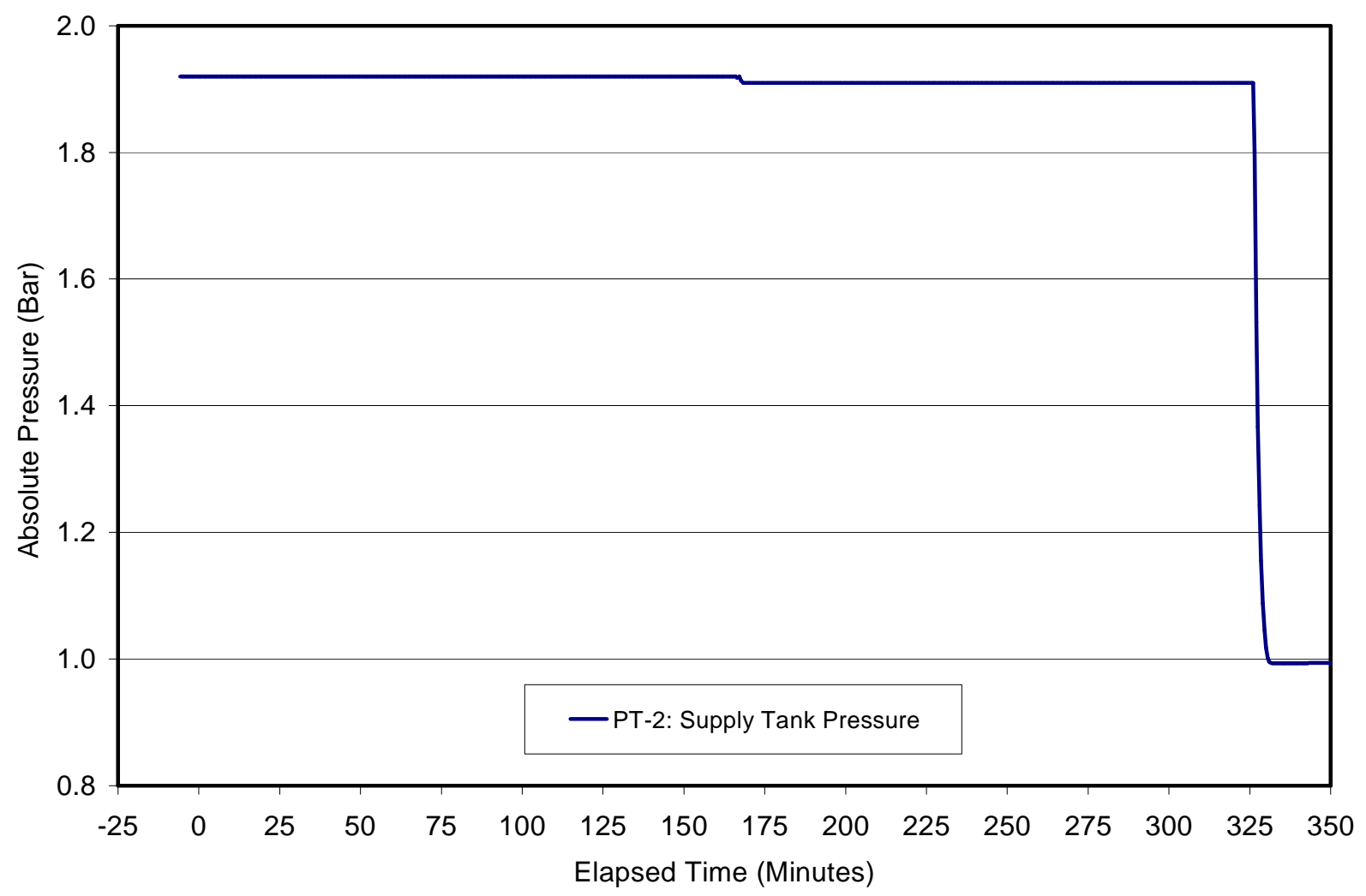

Figure B-59. Water Supply Tank Pressure.

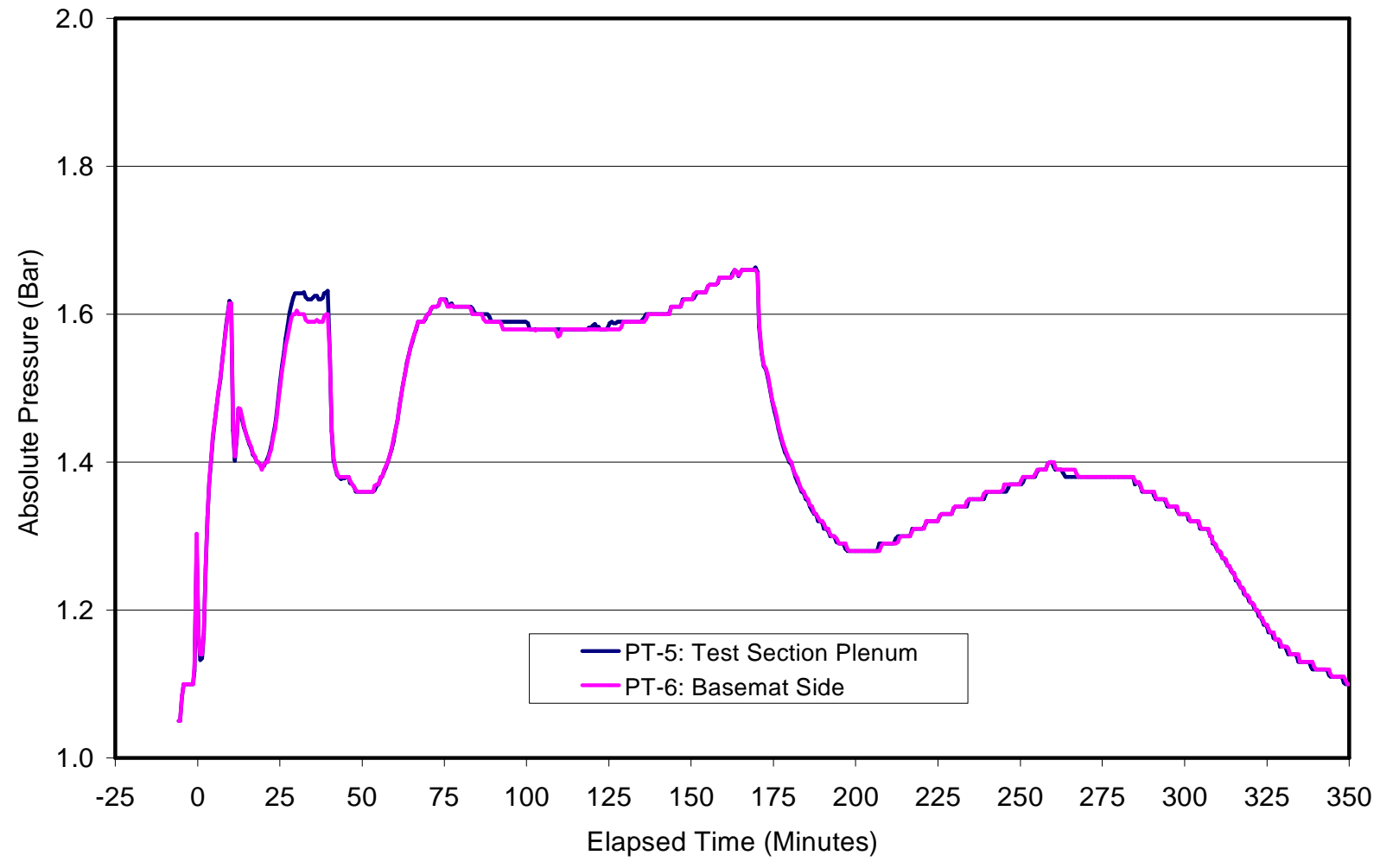

Figure B-60. Test Section Pressure. 


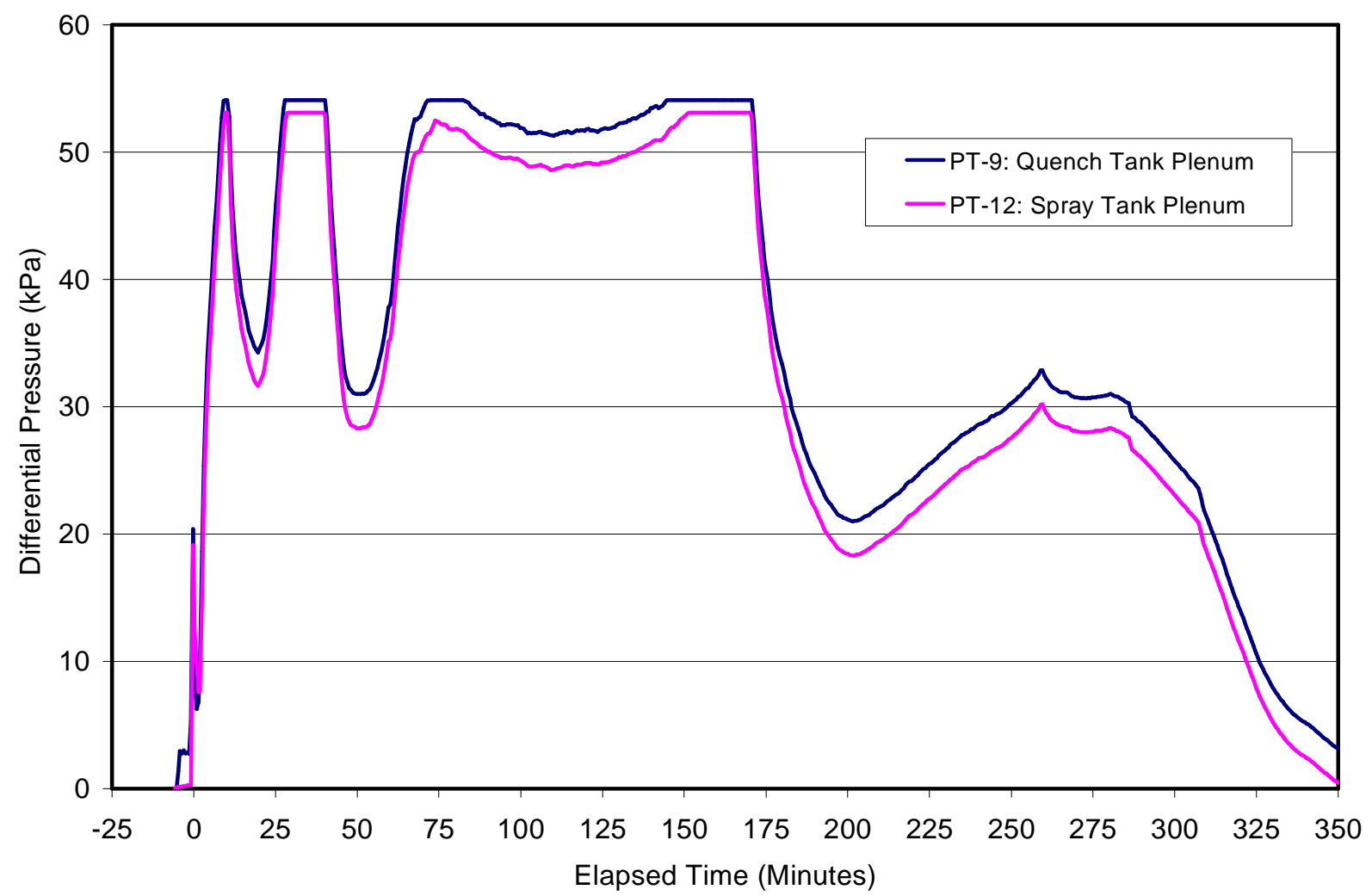

Figure B-61. Quench/Overflow and Spray Tank Plenum Differential Pressures.

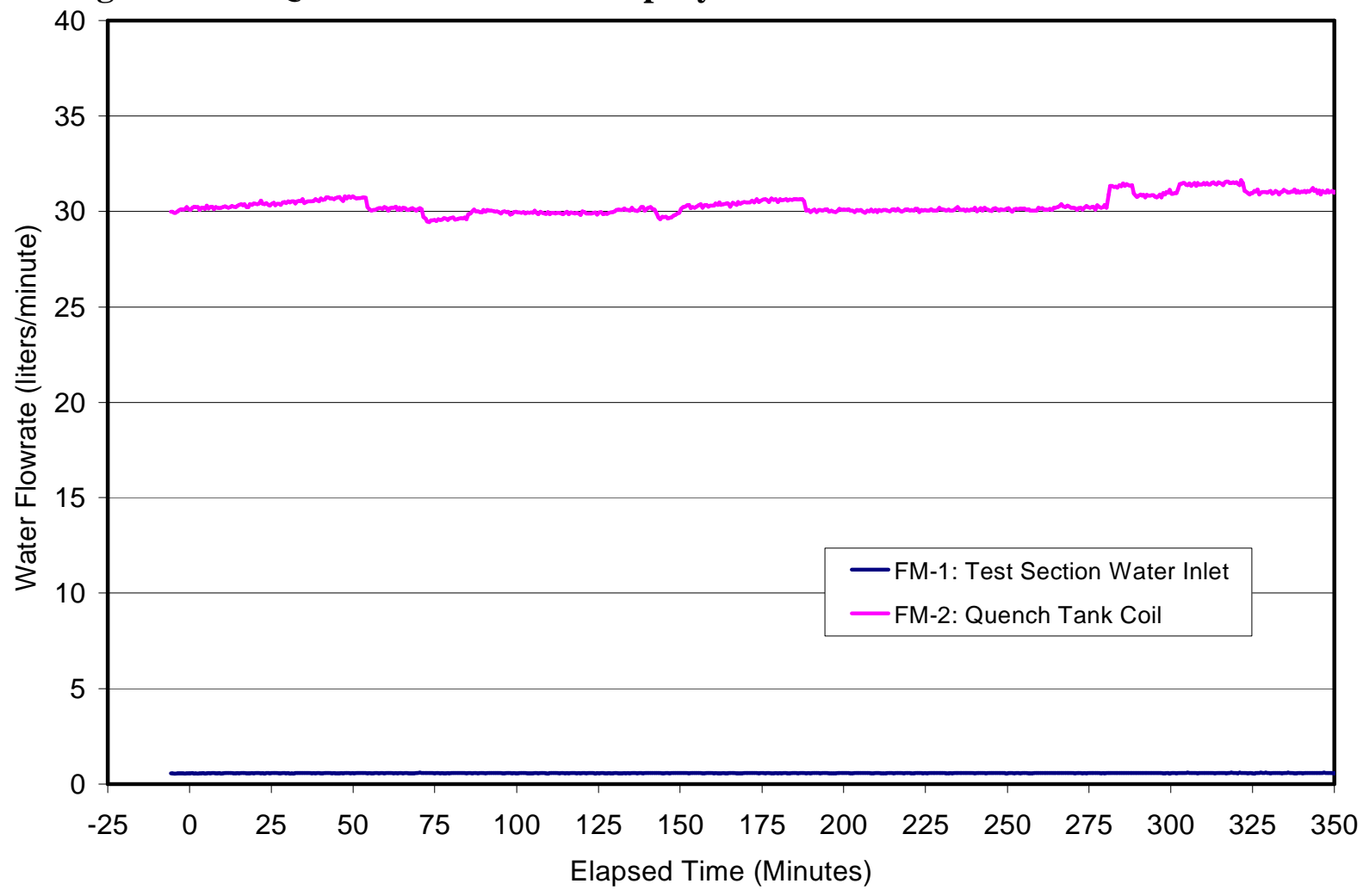

Figure B-62. Water Flow Rates. 
OECD/MCCI-2009-TR06 Rev. 1

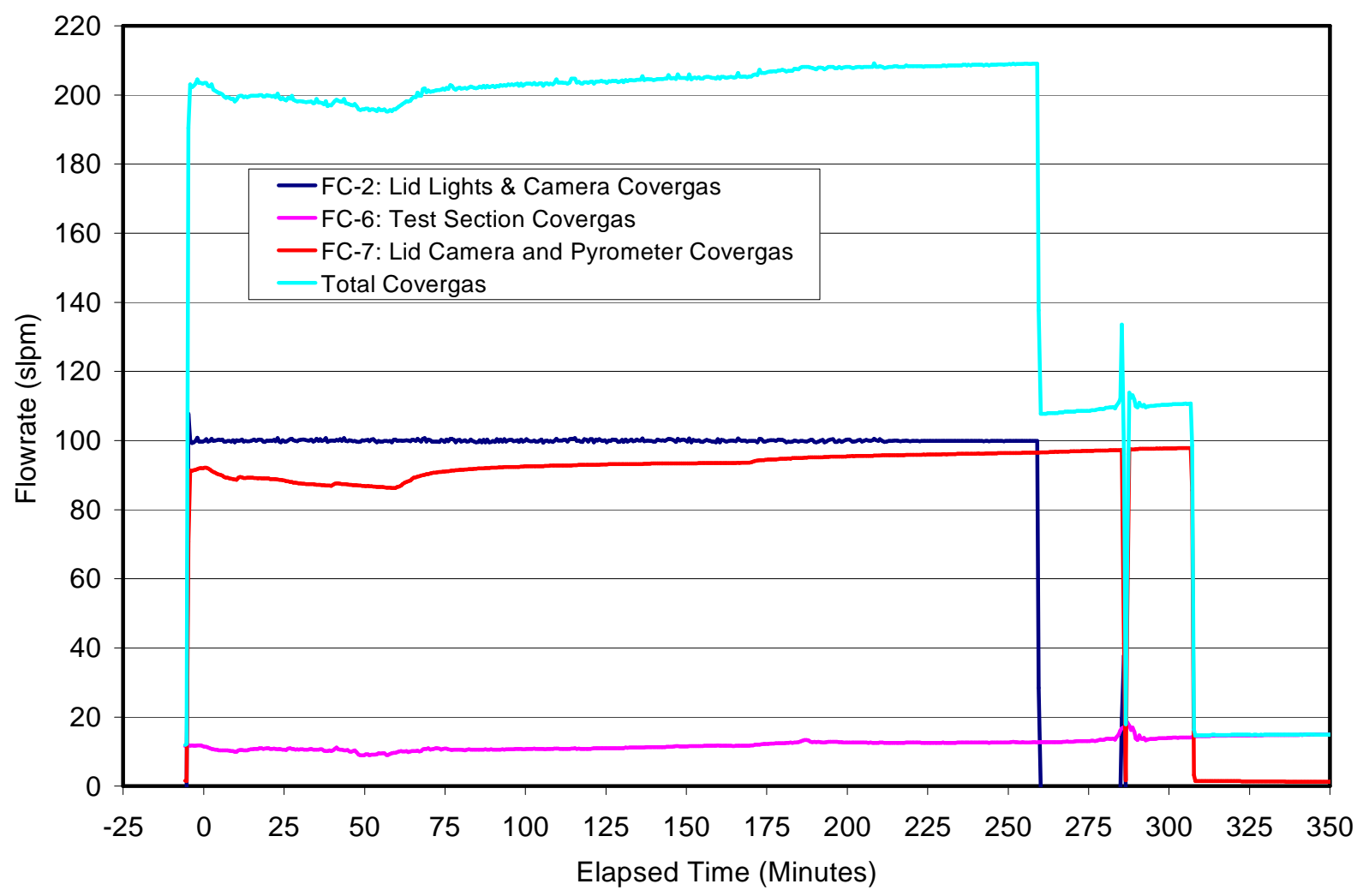

Figure B-63. Test Section Helium Cover Gas Flow Rates.

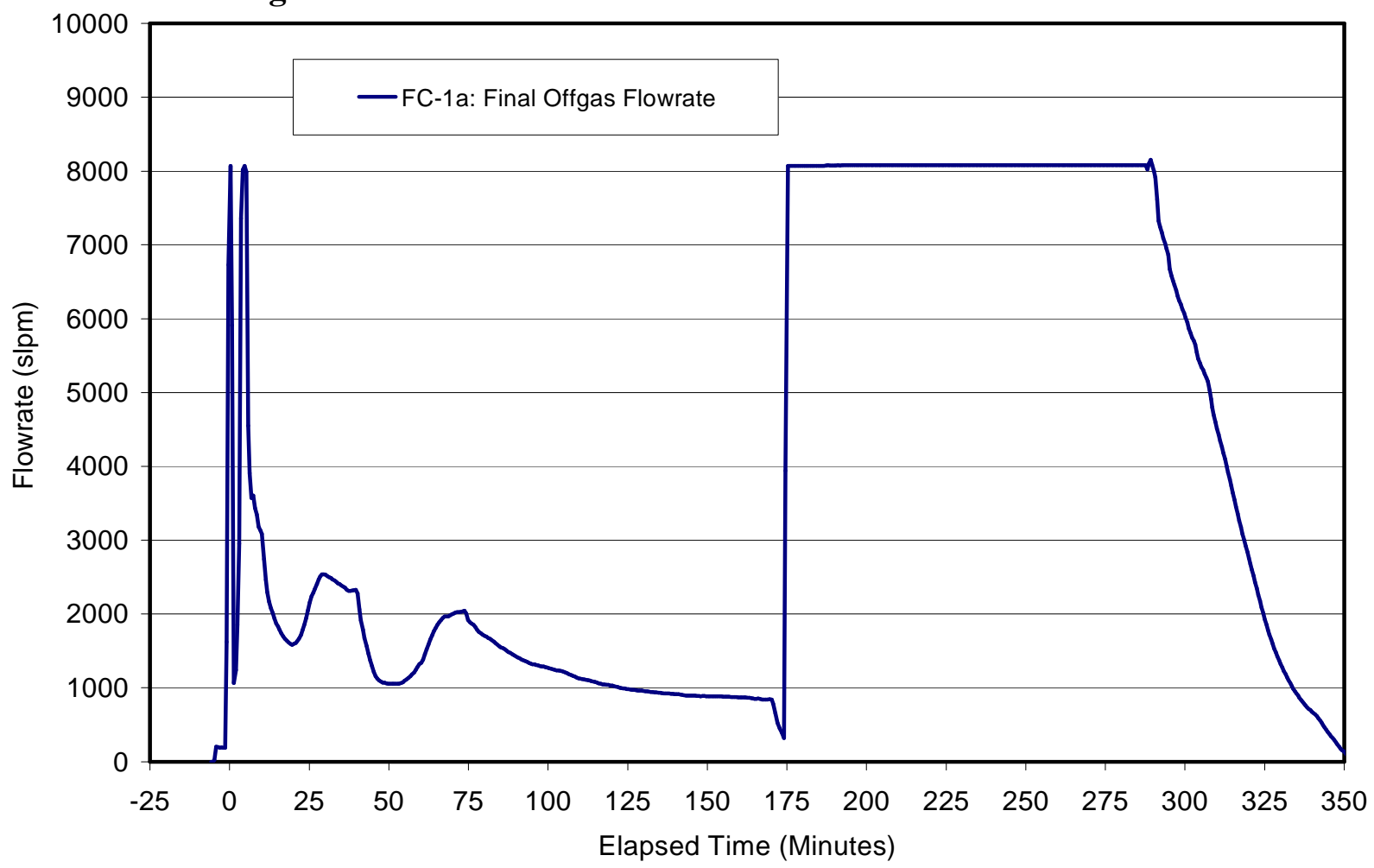

Figure B-64. Final Off Gas Flow Rate. 


\section{APPENDIX C \\ Chemical Analysis Results}

This Appendix provides the raw data from the chemical analysis of the five corium samples that were collected as part of the posttest examinations for CCI-5. Sample locations are described in Section 4.4 of this report.

All samples were analyzed using Inductively Coupled Plasma Atomic Emission Spectroscopy (ICP/AES). The analysis was carried out by the Analytical Chemistry Laboratory (ACL) at Argonne National Laboratory. Results are provided in Table C-1. The ICP/AES analysis provides concentrations of selected elements; the elements have been converted to assumed oxide forms in the table. The resultant mass balance should sum to within the measurement error (reported as $\pm 10 \%$ of the reported elemental concentration for each constituent) if the assumed oxide forms are reasonable and all key sample constituents have been included in the element scan list. As shown in Table C-1, all oxide mass balances fall within this range except sample CCI-7, which was collected from the dense oxide near the core-concrete interface at the center of the test section (see Figure 4-10). The mass balance for this sample is only $\sim 85 \%$, indicating that a significant element was excluded from the scan (unlikely), or the assumed oxide form(s) are not entirely correct. Also note that this sample had a high amount of tungsten (i.e. $\sim 5.8 \mathrm{wt} \%$ in elemental form) relative to the other samples. The tungsten would have been introduced into the melt through dissolution of the tungsten electrodes and thermowells that were in contact with the melt during the experiment. 
OECD/MCCI-2009-TR06 Rev. 1

Table C-1. Raw Data from CCI-5 Sample Analyses. (All constituents with elemental concentrations of $>0.1 \mathrm{wt} \%$ are shown)

\begin{tabular}{|c|c|c|c|c|c|c|c|c|c|c|c|c|c|}
\hline \multirow{3}{*}{ Element } & \multirow{3}{*}{$\begin{array}{l}\text { Oxide } \\
\text { Form }\end{array}$} & \multicolumn{12}{|c|}{ Sample Number } \\
\hline & & \multicolumn{2}{|c|}{ CCI-5 } & \multicolumn{2}{|c|}{ CCI-7 } & \multicolumn{2}{|c|}{ CCI-8 } & \multicolumn{2}{|c|}{ CCI-9 } & \multicolumn{2}{|c|}{ CCI-9 (Dup) } & \multicolumn{2}{|c|}{ CCI-10 } \\
\hline & & $\begin{array}{l}\text { Wt\% } \\
\text { Elem. }\end{array}$ & $\begin{array}{l}\text { Wt\% } \\
\text { Oxide }\end{array}$ & $\begin{array}{l}\text { Wt\% } \\
\text { Elem. }\end{array}$ & $\begin{array}{l}\text { Wt\% } \\
\text { Oxide }\end{array}$ & $\begin{array}{l}\text { Wt\% } \\
\text { Elem. }\end{array}$ & $\begin{array}{l}\text { Wt\% } \\
\text { Oxide }\end{array}$ & $\begin{array}{l}\text { Wt\% } \\
\text { Elem. }\end{array}$ & $\begin{array}{l}\text { Wt\% } \\
\text { Oxide }\end{array}$ & $\begin{array}{l}\text { Wt\% } \\
\text { Elem. }\end{array}$ & $\begin{array}{l}\text { Wt\% } \\
\text { Oxide }\end{array}$ & $\begin{array}{l}\text { Wt\% } \\
\text { Elem. }\end{array}$ & $\begin{array}{r}\text { Wt\% } \\
\text { Oxide }\end{array}$ \\
\hline $\mathrm{Al}$ & $\mathrm{Al}_{2} \mathrm{O}_{3}$ & 1.02 & 1.92 & 0.85 & 1.61 & 1.00 & 1.90 & 1.09 & 2.06 & 1.07 & 2.02 & 1.21 & 2.28 \\
\hline $\mathrm{Ca}$ & $\mathrm{CaO}$ & 8.06 & 11.28 & 7.25 & 10.14 & 7.99 & 11.18 & 8.49 & 11.88 & 8.46 & 11.84 & 9.46 & 13.24 \\
\hline $\mathrm{Cr}$ & $\mathrm{Cr}_{2} \mathrm{O}_{3}$ & 0.13 & 0.20 & 0.08 & 0.12 & 0.14 & 0.20 & 0.19 & 0.27 & 0.18 & 0.26 & 0.23 & 0.34 \\
\hline $\mathrm{Fe}$ & $\mathrm{Fe}_{2} \mathrm{O}_{3}$ & 0.62 & 0.89 & 0.59 & 0.85 & 0.62 & 0.89 & 0.66 & 0.94 & 0.64 & 0.92 & 0.71 & 1.01 \\
\hline $\mathrm{Hf}$ & $\mathrm{HfO}_{2}$ & 0.05 & 0.06 & 0.02 & 0.02 & 0.05 & 0.06 & 0.06 & 0.07 & 0.05 & 0.06 & 0.06 & 0.07 \\
\hline $\mathrm{Mg}$ & $\mathrm{MgO}$ & 0.36 & 0.60 & 0.28 & 0.47 & 0.36 & 0.59 & 0.38 & 0.62 & 0.37 & 0.62 & 0.41 & 0.69 \\
\hline $\mathrm{Mn}$ & $\mathrm{MnO}$ & 0.03 & 0.03 & 0.02 & 0.03 & 0.03 & 0.03 & 0.03 & 0.03 & 0.03 & 0.03 & 0.03 & 0.04 \\
\hline $\mathrm{Ni}$ & $\mathrm{NiO}$ & 0.02 & 0.02 & 0.06 & 0.08 & 0.02 & 0.02 & 0.02 & 0.03 & 0.02 & 0.03 & 0.02 & 0.02 \\
\hline $\mathrm{K}$ & $\mathrm{K}_{2} \mathrm{O}$ & 0.36 & 0.44 & 0.34 & 0.41 & 0.36 & 0.43 & 0.39 & 0.46 & 0.38 & 0.46 & 0.43 & 0.52 \\
\hline $\mathrm{Si}$ & $\mathrm{SiO}_{2}$ & 15.49 & 33.14 & 14.22 & 30.42 & 15.64 & 33.45 & 16.31 & 34.90 & 16.31 & 34.90 & 18.25 & 39.05 \\
\hline $\mathrm{Na}$ & $\mathrm{Na}_{2} \mathrm{O}$ & 0.22 & 0.30 & 0.19 & 0.26 & 0.22 & 0.30 & 0.23 & 0.31 & 0.23 & 0.31 & 0.26 & 0.35 \\
\hline $\mathrm{Sr}$ & $\mathrm{SrO}$ & 0.02 & 0.02 & 0.01 & 0.02 & 0.02 & 0.02 & 0.02 & 0.02 & 0.02 & 0.02 & 0.02 & 0.02 \\
\hline $\mathrm{Ti}$ & $\mathrm{TiO}_{2}$ & 0.18 & 0.31 & 0.12 & 0.20 & 0.18 & 0.30 & 0.19 & 0.32 & 0.19 & 0.31 & 0.21 & 0.35 \\
\hline $\mathrm{U}$ & $\mathrm{UO}_{2}$ & 26.35 & 29.89 & 22.62 & 25.67 & 25.65 & 29.10 & 24.26 & 27.53 & 23.78 & 26.98 & 20.42 & 23.16 \\
\hline W & $\mathrm{WO}_{3}$ & 1.06 & 1.34 & 5.79 & 7.31 & 0.92 & 1.15 & 0.87 & 1.10 & 0.86 & 1.09 & 0.99 & 1.25 \\
\hline $\mathrm{Zr}$ & $\mathrm{ZrO}_{2}$ & 7.98 & 10.77 & 5.72 & 7.72 & 7.95 & 10.74 & 8.20 & 11.07 & 8.15 & 11.01 & 8.48 & 11.46 \\
\hline Total & & & 91.23 & & 85.31 & & 90.37 & & 91.61 & & 90.87 & & 93.84 \\
\hline
\end{tabular}

